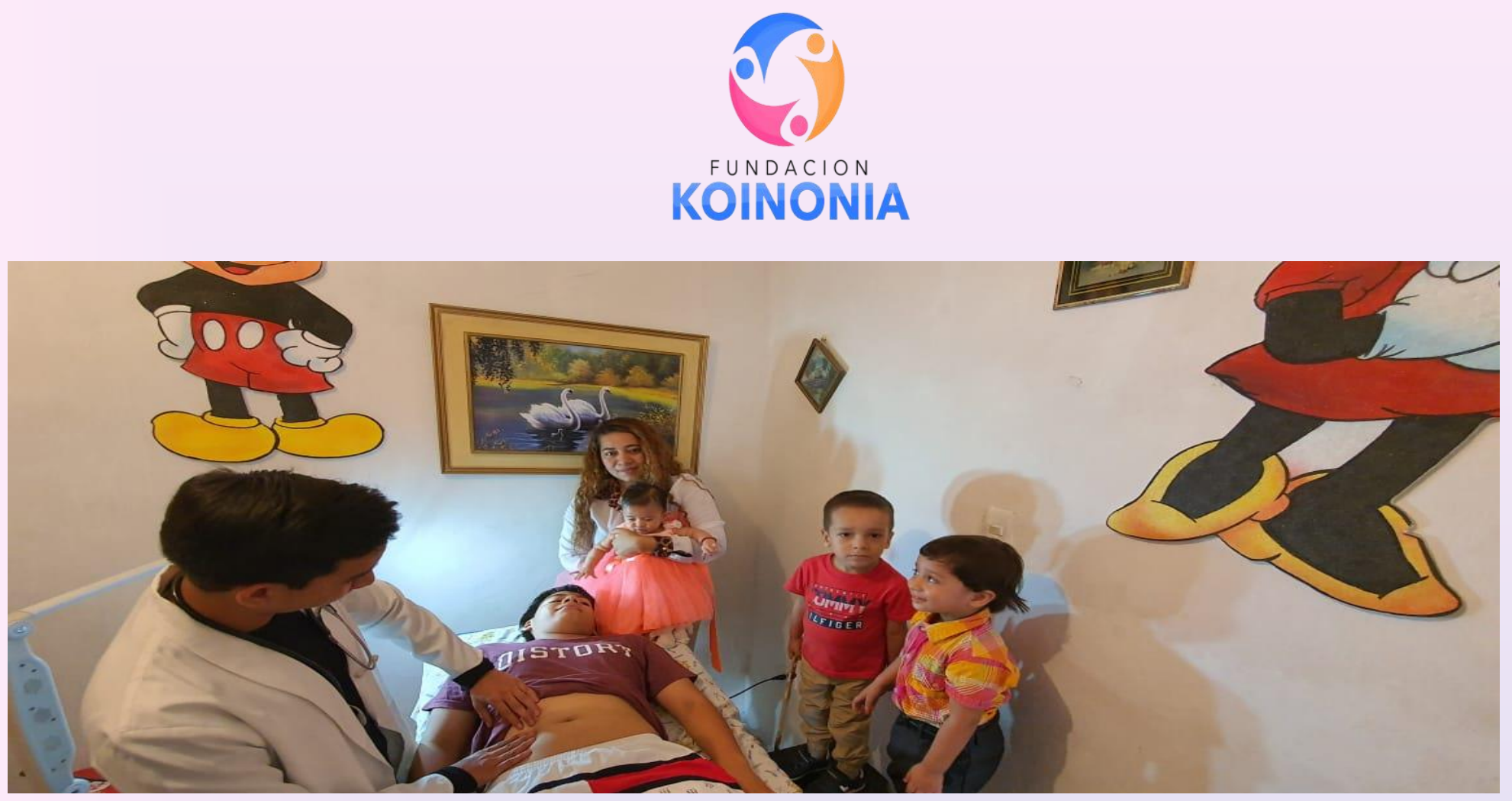

\title{
Sistema Genito - Urinario \\ y Endocrino
}

ISBN: 978-980-7792-34-9 
Sistema Genito - Urinario y Endocrino

DOI:

https://doi.org/10.35381/978-980-7792-30-2 


\section{Sistema Genito - Urinario y Endocrino}

\section{Editado y distribuido por}

(c) FUNDACIÓN KOINONIA (980-7792)

Santa Ana de Coro, Venezuela. 2020.

Correo electrónico: fundakoinonia@gmail.com

Hecho el Depósito de Ley.

Depósito Legal: FA2019000068

ISBN: 978-980-7792-34-9

Colección: Salud y Vida

Serie: Fisiología Humana

Anatomía y Fisiología Urogenital - Endocrino

Autores: () Patricio Alfredo Vallejo Valdivieso (c) Graciela Zambrano Pincay

(c) Nívea Katherine Vallejo Valdivieso @ Patricio Yosué Vallejo Pilligua

(c) María Elena Moya Martínez (c) Gelen Bravo Cedeño (c) Luis Alejandro Vallejo Valdivieso

Todos los libros publicados por la Fundación Koinonía son sometidos previamente a un proceso de evaluación realizado por árbitros calificados.

Esta obra está únicamente destinada al uso personal y colectivo en trabajos académicos, de investigación, docencia y difusión del Conocimiento.

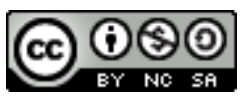

C 2020 por los autores. Esta obra es de acceso abierto y distribuido según los términos y condiciones de la licencia Creative Commons Atribución-NoComercial-
Compartirlgual
4.0
Internacional
(CC
BY-NC-SA
4.0)

(https://creativecommons.org/licenses/by-nc-sa/4.0/).

Revisión, Ortografía y Redacción:

Dra. Carlina García

Diseño de portada:

Dr. Julio Aldana

\section{Diagramación:}

Licdo. Rodolfo Albarrán 


\section{FONDO EDITORIAL KOINONÍA \\ Director Editor \\ Dr. Julio Aldana}

Comité Editorial

Dr. Jairo Villasmil

Dr. Josía Isea

Dra. Carlina García.

Licda. Carol lanni. MSc.

\section{Comité Científico}

Dr. Lucio Noriero Escalante Licda. Marieudil López. MSc.

Dra. Maribel Giménez

Dra. Lenys Piña Ferrer

Psic. Nicolás Rodríguez. MSc.

Dr. Jesús Pirona

Dr. Reinaldo Velasco 


\section{CONSTANCIA DE ARBITRAJE}

El Fondo Editorial "Fundación Koinonía", hace constar que este libro proviene de una investigación realizada por los autores, siendo sometido a un arbitraje de contenido y forma por jurados especialistas. Además, se realizó una revisión del enfoque, paradigma y método investigativo; desde la matriz epistémica asumida por el autor, aplicándose las normas APA, Sexta Edición, proceso de anti plagio en línea, garantizándose así la cientificidad de la obra.

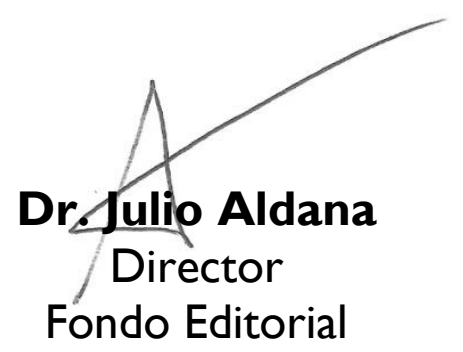

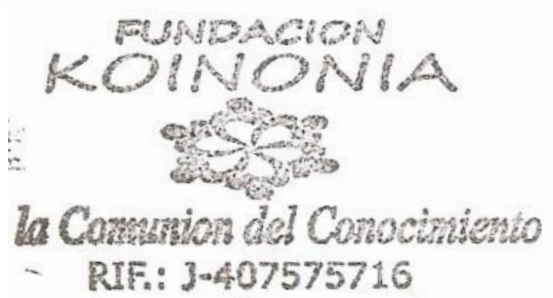

RIF: J-407575716 


\section{ÍNDICE GENERAL}

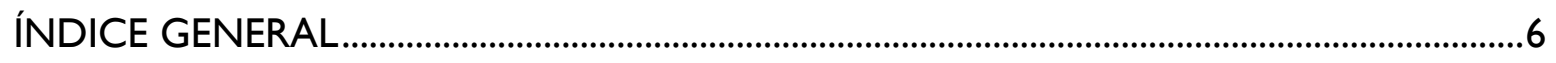

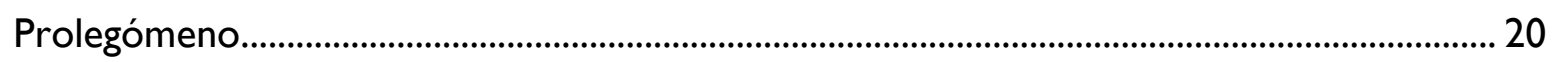

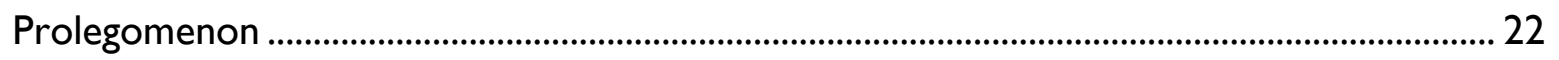

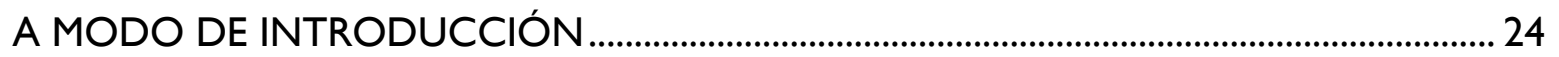

El aparato reproductor a lo largo de la vida.................................................................................. 24

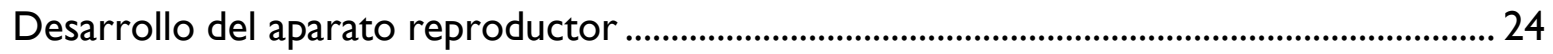

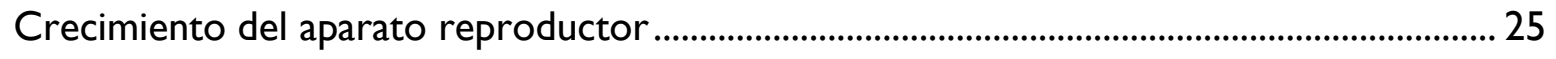

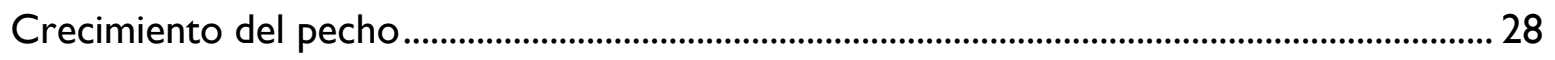

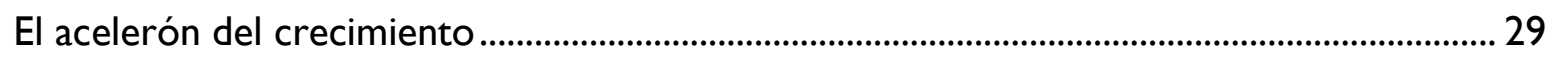

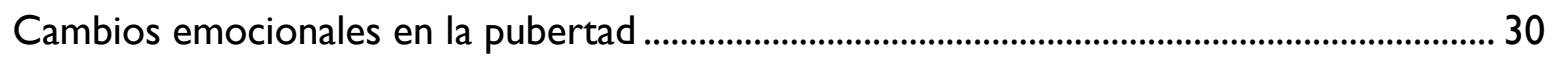

Inicio precoz y tardío de la pubertad ............................................................................................ 30

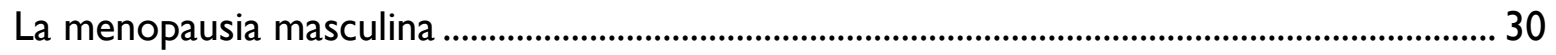

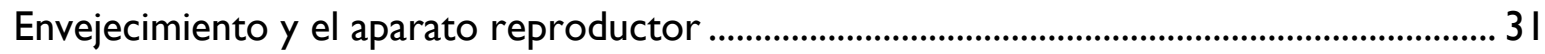

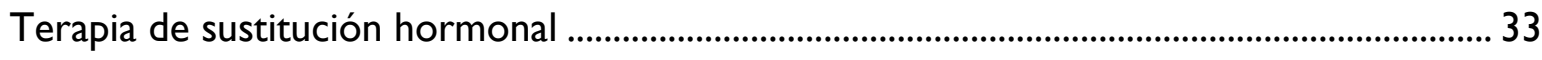

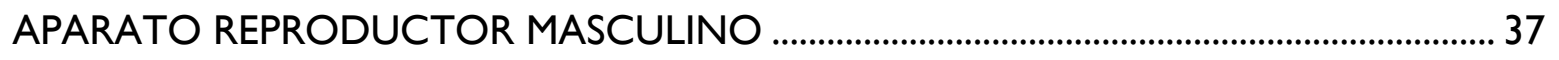

Funciones del aparato reproductor masculino ...................................................................... 37

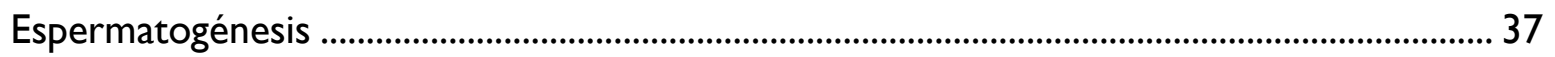

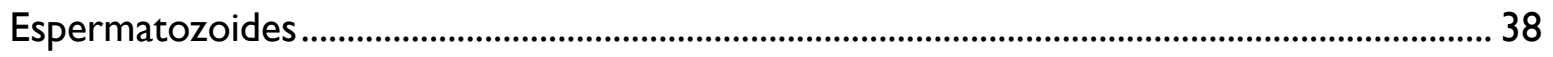

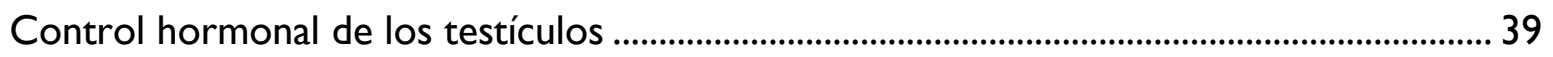

Conductos del aparato reproductor masculino ................................................................. 4 I 


\section{Sistema Genito - Urinario y Endocrino}

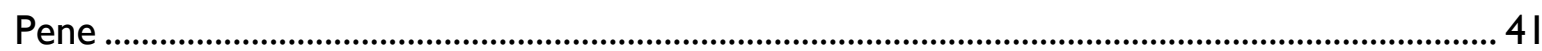

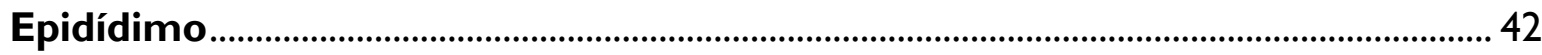

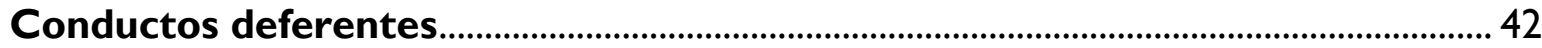

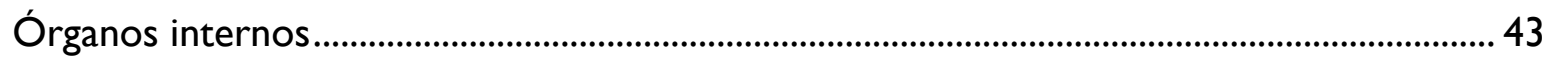

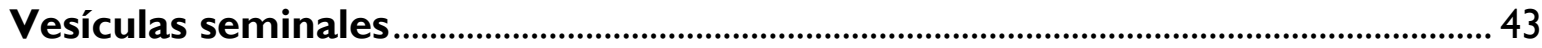

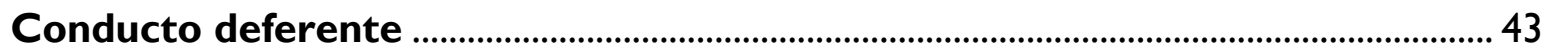

Próstata

Uretra

Glándulas bulbouretrales ......................................................................................................... 44

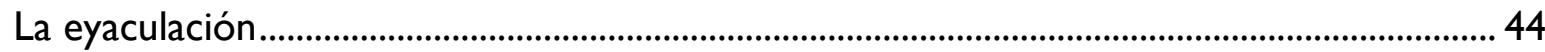

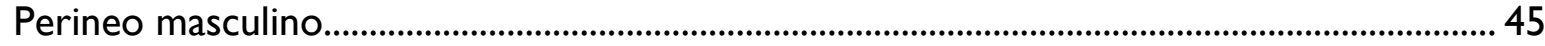

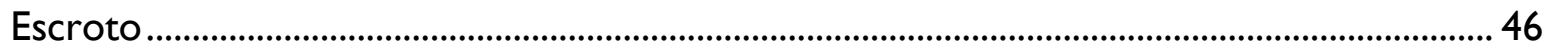

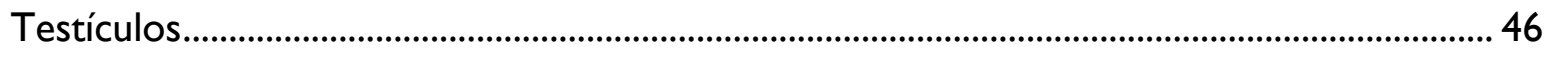

APARATO REPRODUCTOR FEMENINO …………………................................................. 49

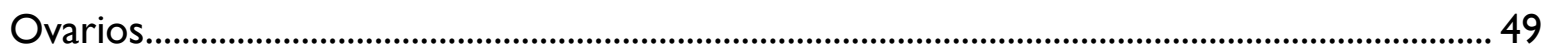

Ovogénesis y desarrollo folicular.............................................................................................. 5 I

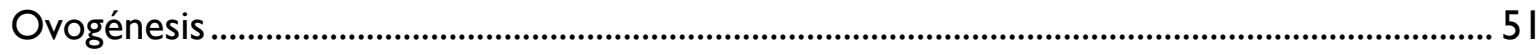

Diferenciación ovárica durante el desarrollo embrionario ........................................................ 52

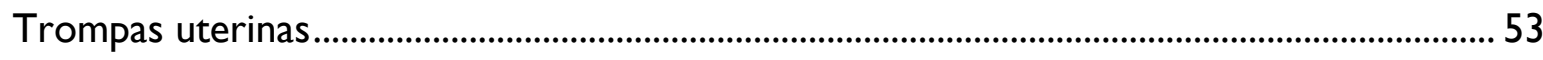

Anatomáa microscópica. .................................................................................................... 53

Útero

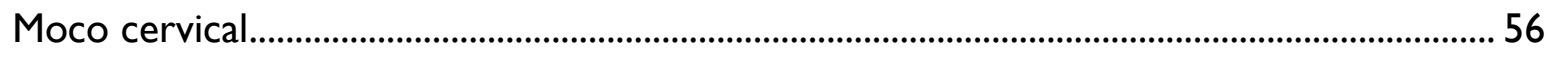

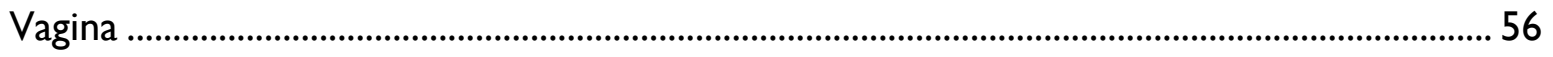




\section{Sistema Genito - Urinario y Endocrino}

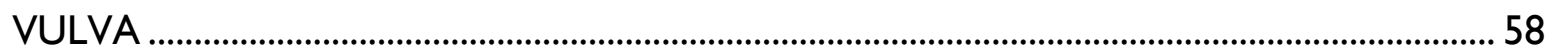

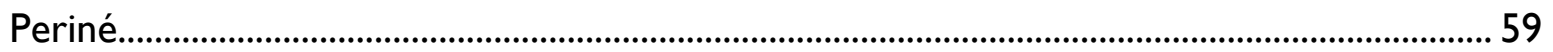

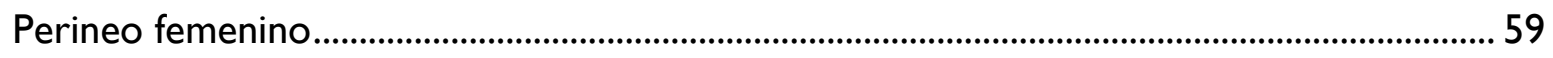

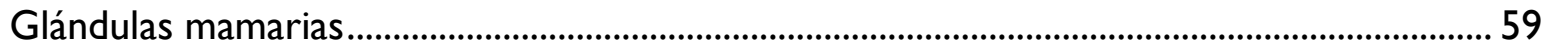

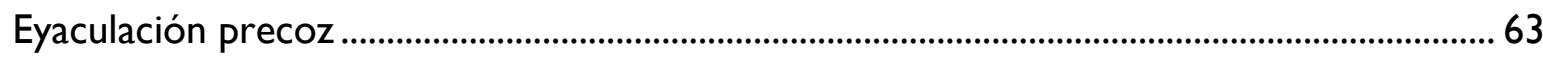

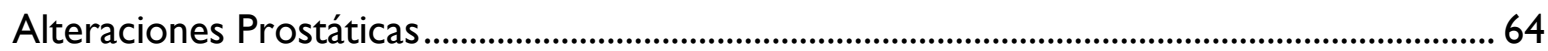

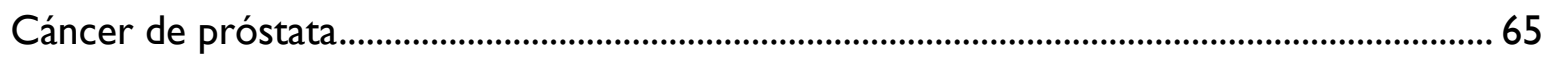

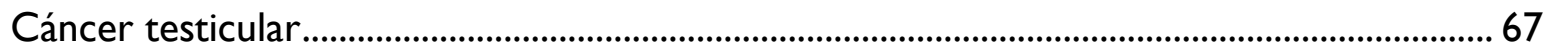

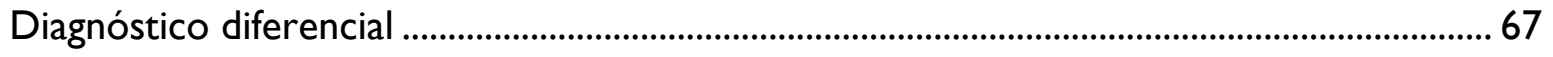

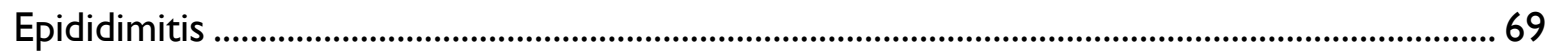

Aparato reproductor masculino. Valores de laboratorio.......................................................... 70

Hormonas implicadas en la fertilidad masculina ....................................................................... 7 I

Pruebas para el estudio de la fertilidad masculina .................................................................... 72

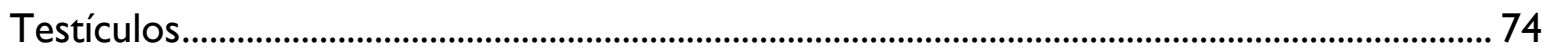

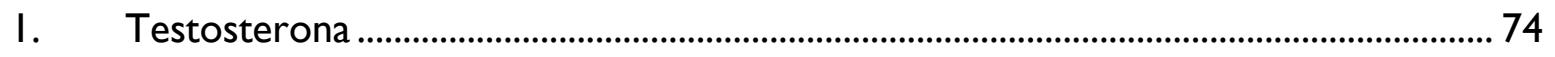

Razones por las que se realiza el examen ....................................................................... 74

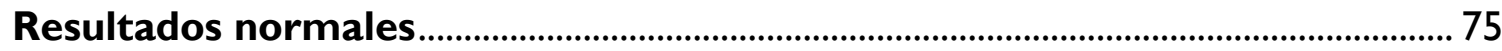

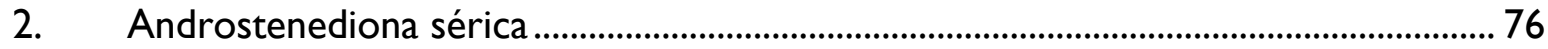

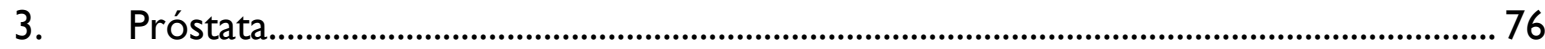

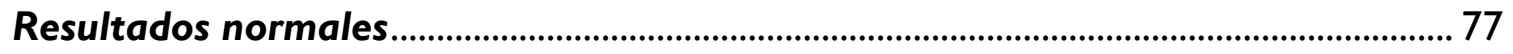

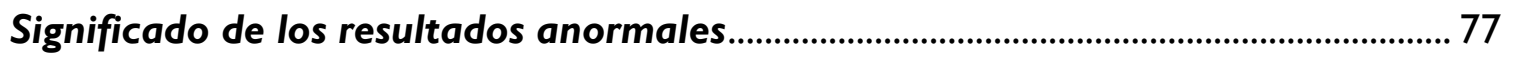

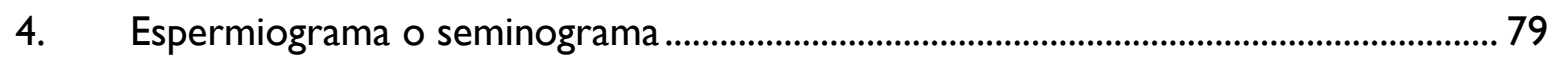

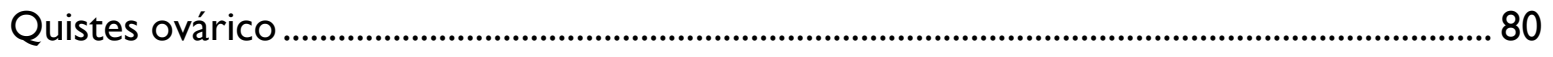




\section{Sistema Genito - Urinario y Endocrino}

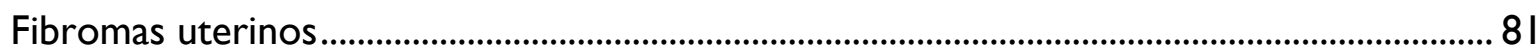

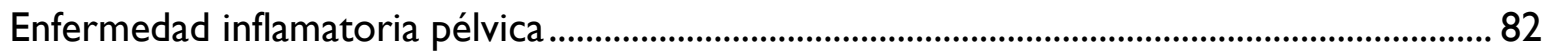

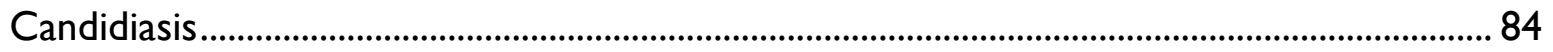

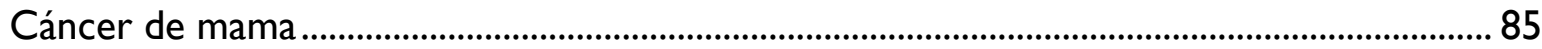

Cáncer de ovario

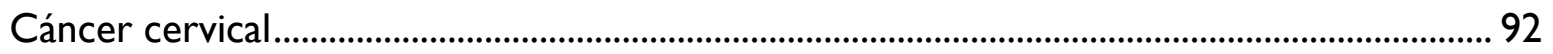

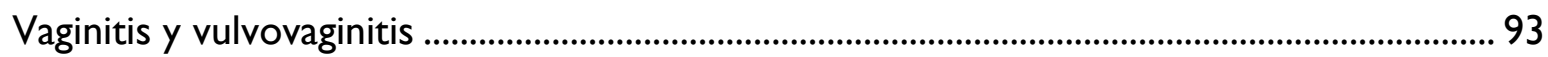

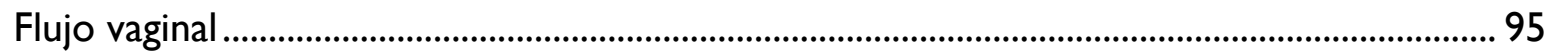

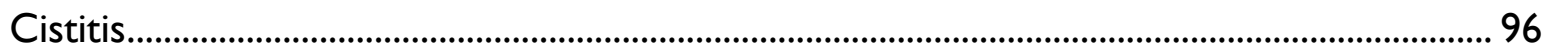

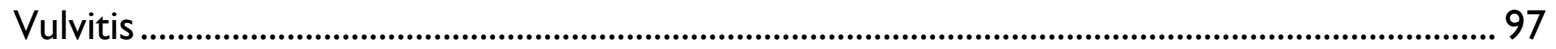

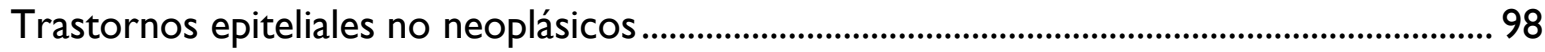

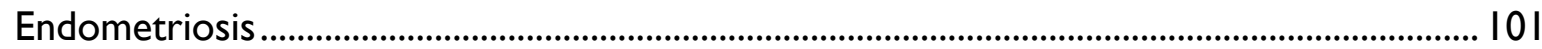

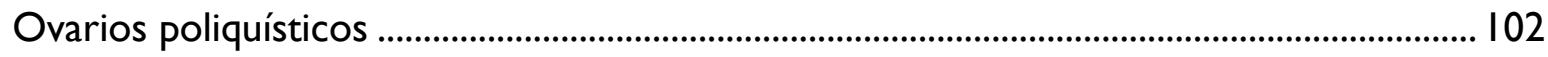

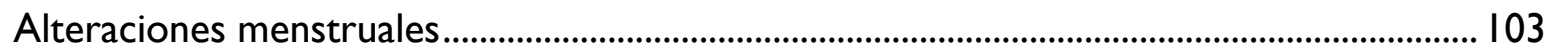

Trastornos del ritmo o frecuencia....................................................................................... 104

Causas de las irregularidades menstruales ......................................................................... 106

Exámenes de laboratorio aparato reproductor femenino .................................................. 107

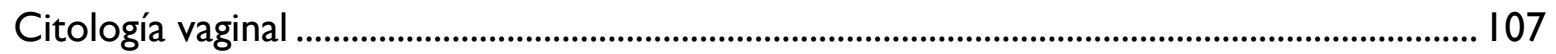

Otros exámenes incluyen ............................................................................................................... 109

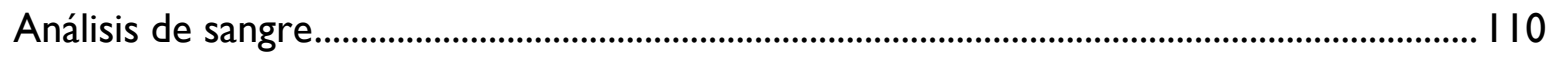

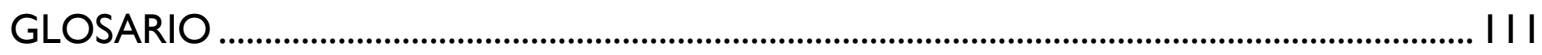

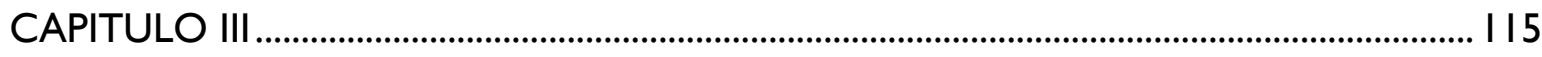

HORMONAS SEXUALES ................................................................................................... I I 


\section{Sistema Genito - Urinario y Endocrino}

Hormonas sexuales femeninas...................................................................................... I

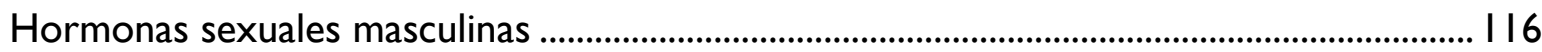

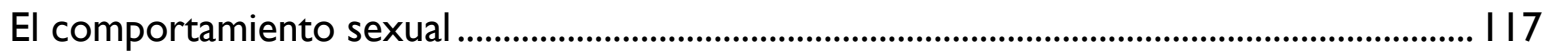

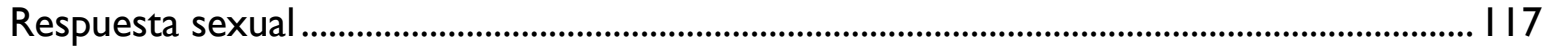

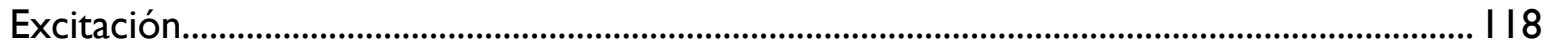

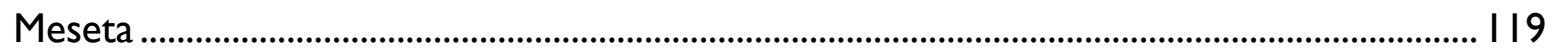

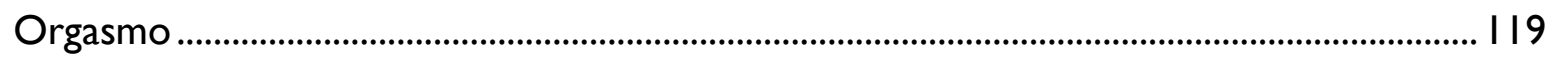

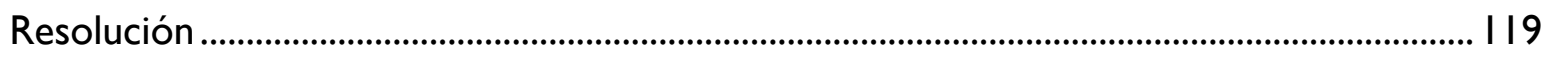

ZONAS EROGENAS Y RELACIONES SEXUALES ........................................................ I 2 I

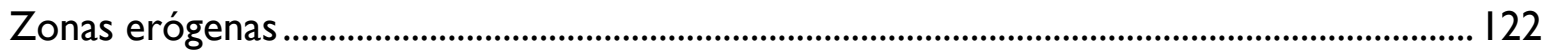

Zonas erógenas genitales masculinas ....................................................................................... $\mid 22$

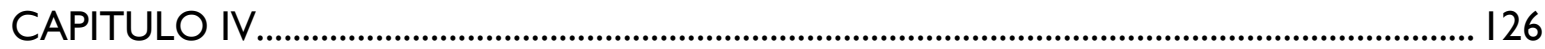

PARAFILIA

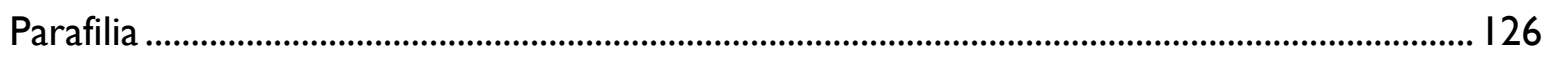

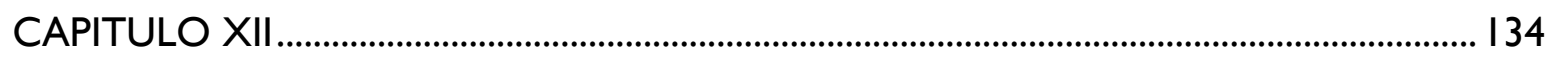

ENFERMEDADES DE TRASMISION SEXUAL ............................................................. $\mid 34$

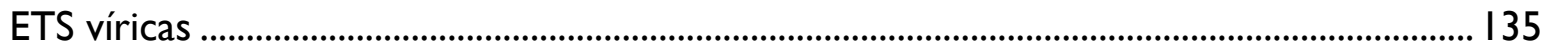

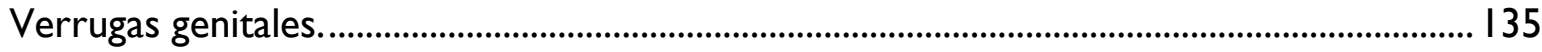

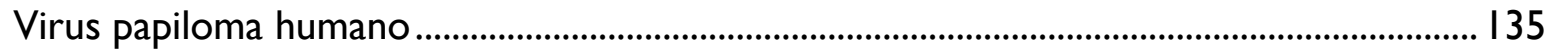

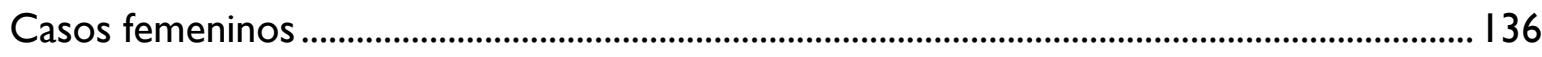

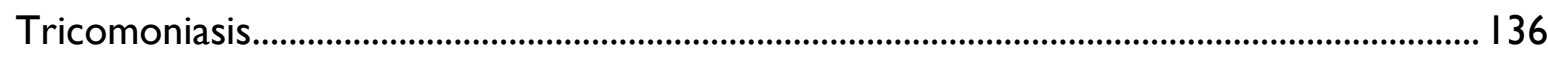

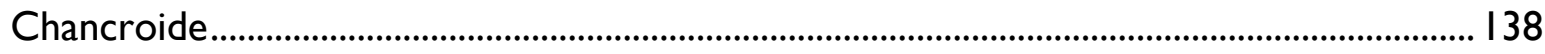

Herpes genital......................................................................................................................... I 39 


\section{Sistema Genito - Urinario y Endocrino}

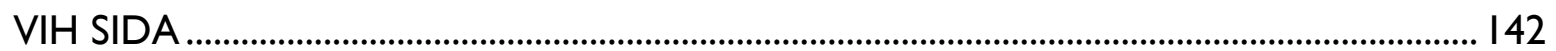

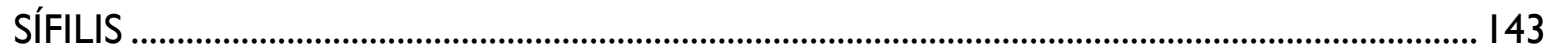

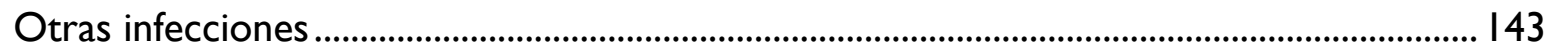

CAPITULO VIII .......................................................................................................... 146

PROBLEMAS EN EL EMBARAZO Y EN EL NACIMIENTO ..................................................... 446

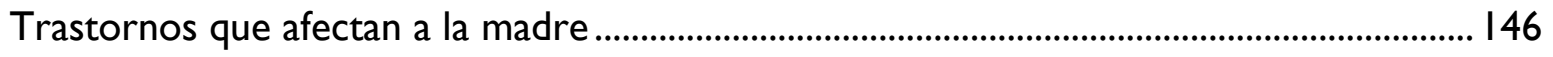

Insuficiencia placentaria ...................................................................................................... $/ 49$

Placenta previa .............................................................................................................. 150

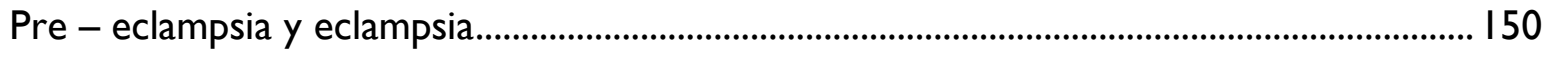

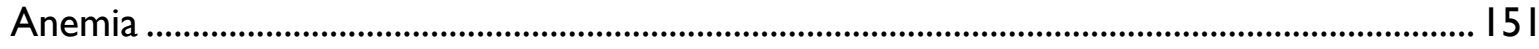

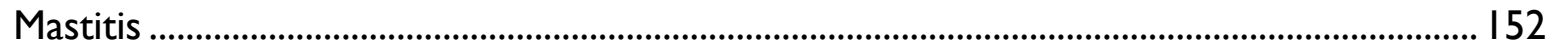

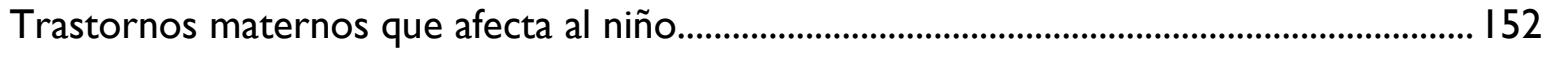

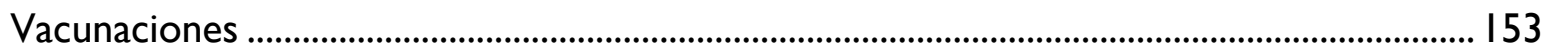

Complicación que afectan al feto ......................................................................................... 154

Problemas de parto ....................................................................................................... 154

Lesiones del sistema nervioso central....................................................................................... 160

MANEJO DE LA COMPLICACIONES DE LOS TRASTORNOS HIPERTENSIVOS

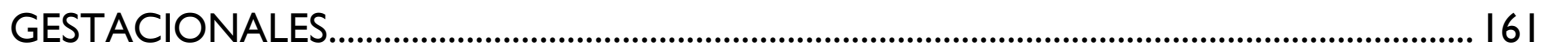

Hematoma Subscapular Hepático …………………………………………………………. 161

Coagulación Intravascular Diseminada (CID) ...................................................................... 162

Insuficiencia Renal Aguda .................................................................................................... 164

Insuficiencia Pre renal ........................................................................................................... 164

CAPITULO IX 


\section{Sistema Genito - Urinario y Endocrino}

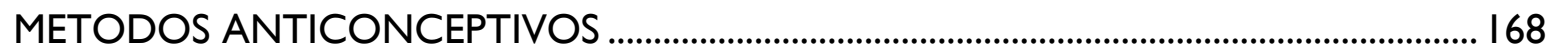

Anticoncepción natural ............................................................................................................ 168

Coito interrupto o método del retiro ........................................................................................ 168

Monitor de anticoncepción Clearblue ……………………………………………………….... 169

Método del ritmo o del calendario.............................................................................................. 169

Anticonceptivos de barrera.................................................................................................... 170

Diafragma o capuchón cervical .............................................................................................. 17

Anticonceptivos hormonales..................................................................................................... 171

Píldora anticonceptiva............................................................................................................... 17 I

Esterilización .......................................................................................................................... $/ 74$

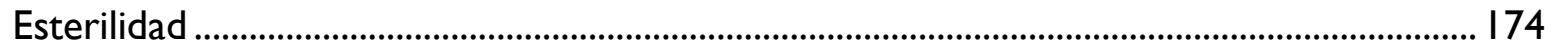

Hipogonadismo hipogonadotropo ......................................................................................... 175

Síndrome de Klinefelter ............................................................................................................. 175

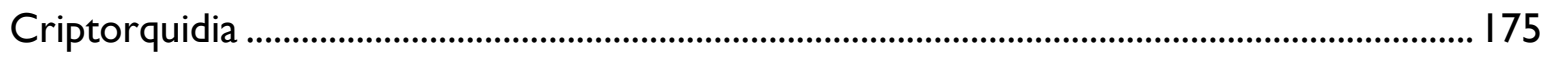

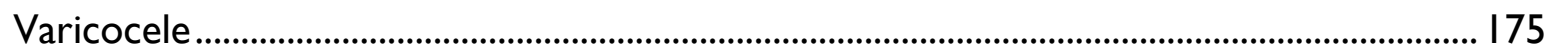

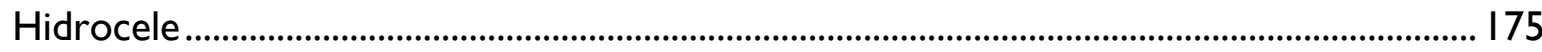

Disgenesia gonadal $X Y$.......................................................................................................... 175

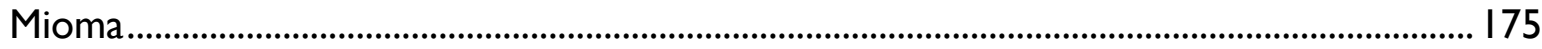

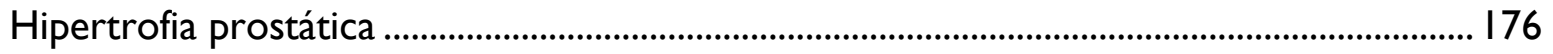

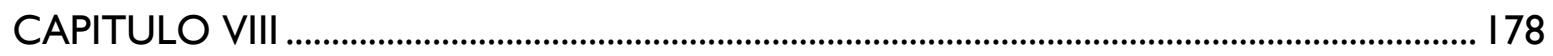

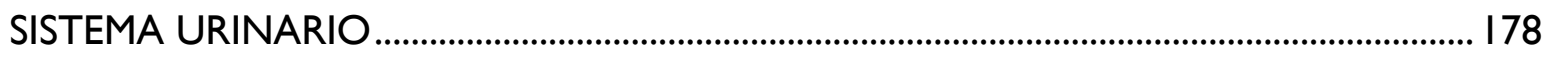

Generalidades de las funciones del riñón y su anatomía .......................................................... 179

Anatomía externa de los riñones........................................................................................... 180 


\section{Sistema Genito - Urinario y Endocrino}

Morfologia interna: seno, parénquima renal ........................................................................... |8|

Vías urinarias intrarrenales: cálices y pelvis renal .............................................................. 183

Extrarrenales: uréteres, vejiga y uretra ......................................................................... 184

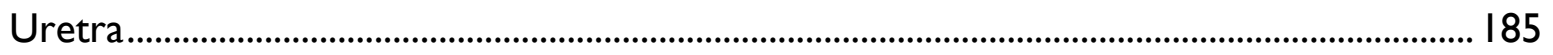

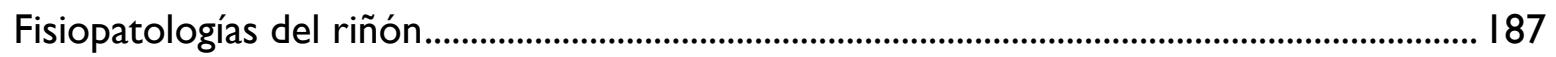

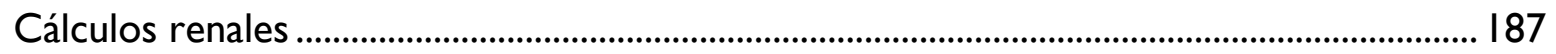

Fisiopatologías que provoca la filtración glomerular. ......................................................... 188

Fisiopatologías provocadas en la reabsorción y secreción tubular......................................... 188

Fisiopatología provocadas por la producción de orina diluida y concentrada.................... 190

Fisiopatologías provocadas por el mal funcionamiento renal ............................................ 190

Fisiopatologías del transporte almacenamiento y eliminación de la orina ............................ I92

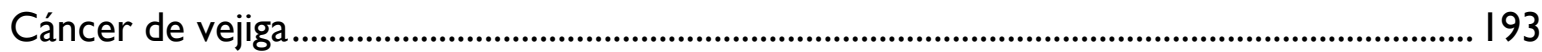

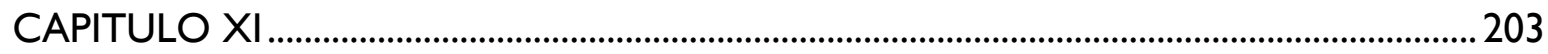

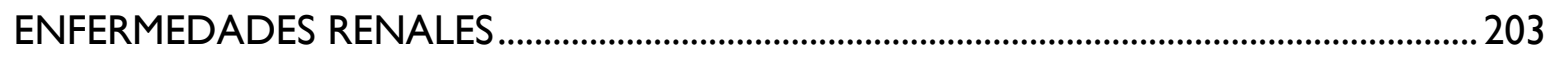

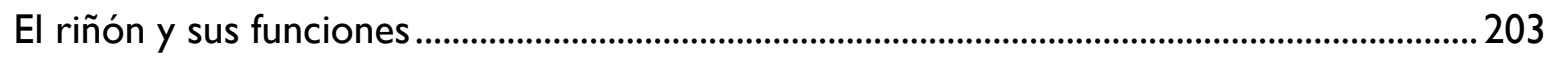

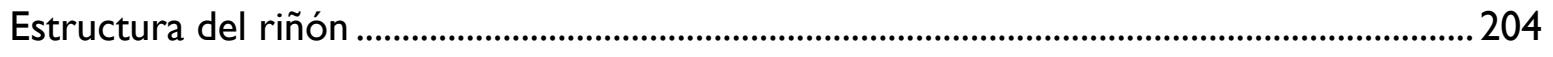

¿Por qué es el riñón esencial para el cuerpo? ................................................................................204

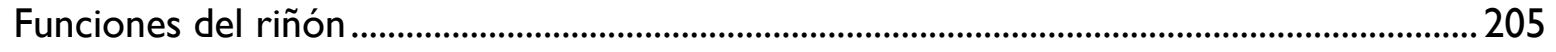

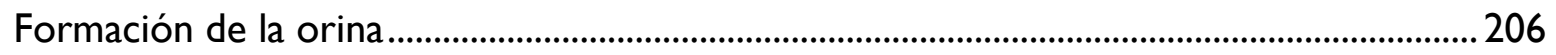

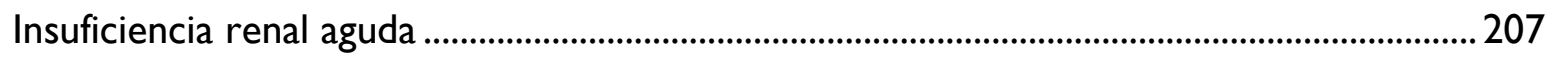

Clasificación, etiología y fisiopatología ........................................................................................ 208

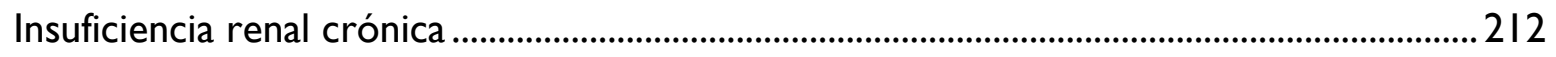

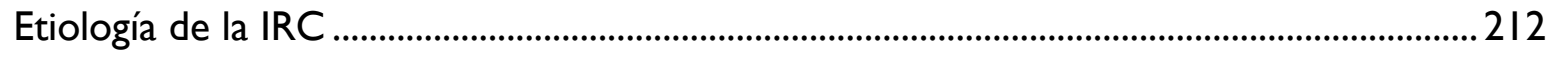




\section{Sistema Genito - Urinario y Endocrino}

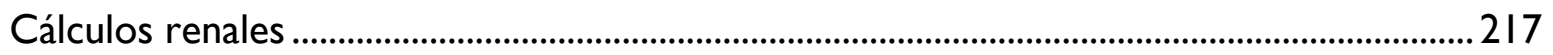

Tipos de cálculos renales ...................................................................................................... 218

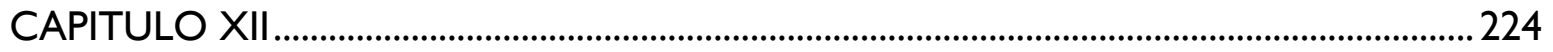

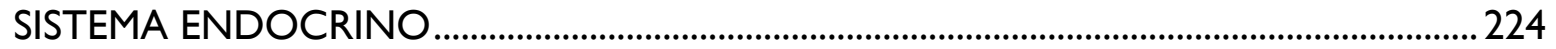

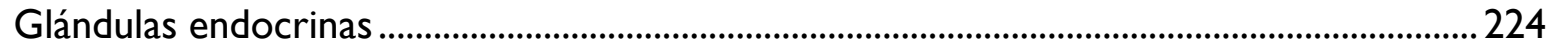

El hipotálamo y la glándula hipófisis .........................................................................................22

Tipos de células del lóbulo anterior de la hipófisis y sus hormonas ......................................226

Hormona de crecimiento humano y factores de crecimiento similares a la insulina..........227

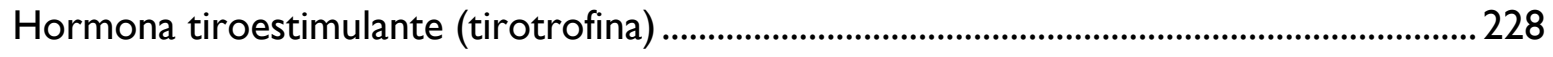

Hormona folículo-estimulante ..................................................................................................228

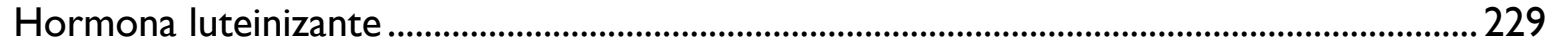

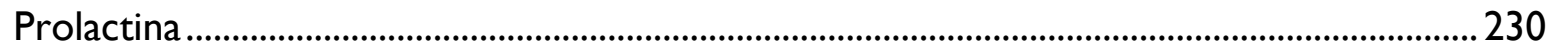

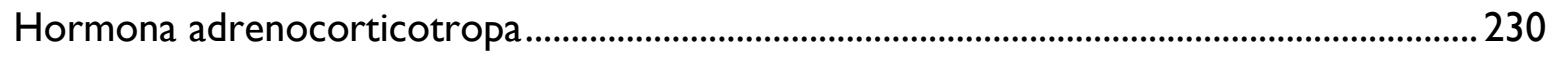

Hormona melanocitoestimulante.................................................................................................23

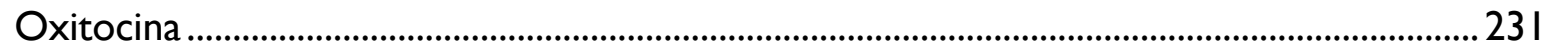

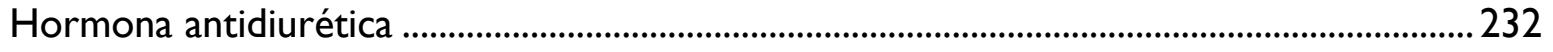

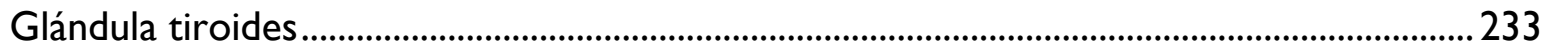

Las glándulas paratiroides. .......................................................................................................234

Glándulas suprarrenales ...................................................................................................... 234

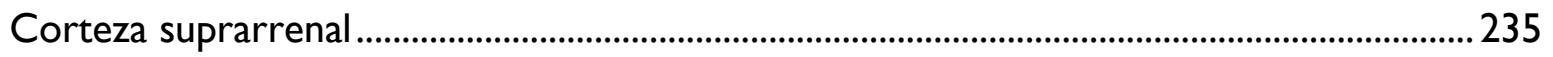

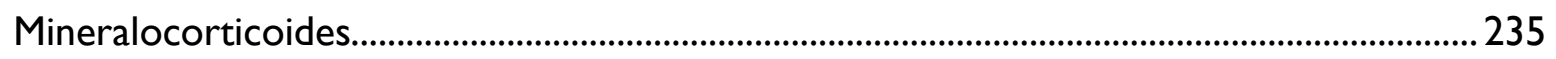

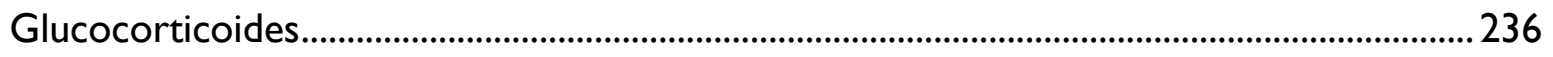

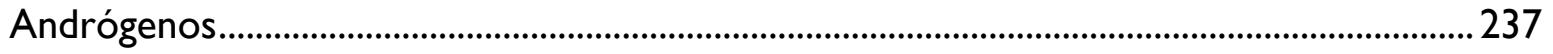




\section{Sistema Genito - Urinario y Endocrino}

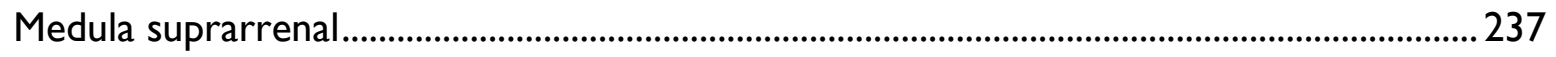

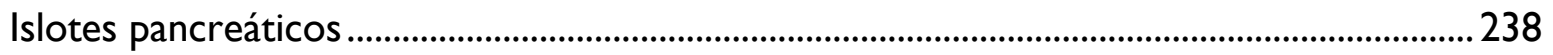

Tipos celulares en los islotes pancreáticos ..............................................................................238

Ovarios y testículos...................................................................................................................... 239

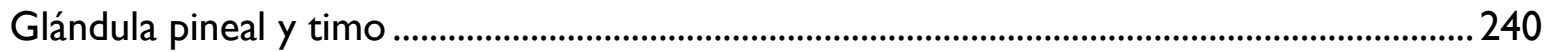

Fisiología del sistema endocrino ..............................................................................................24 I

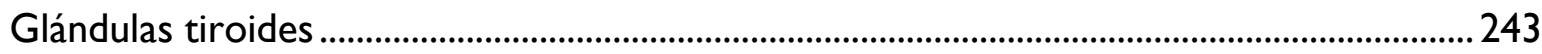

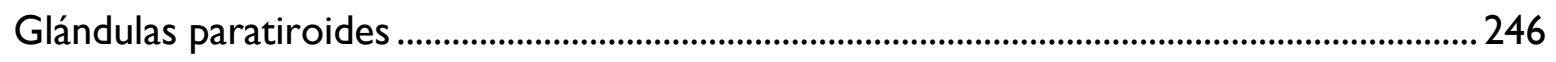

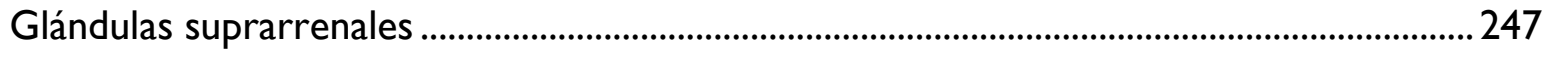

Islotes pancreáticos ................................................................................................................ 249

Regulación de la secreción de glucagón e insulina ..................................................................250

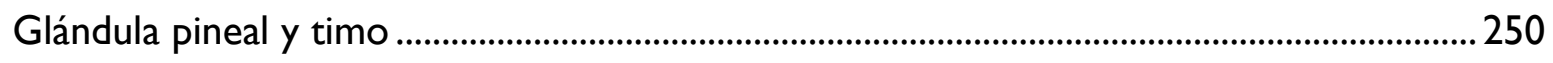

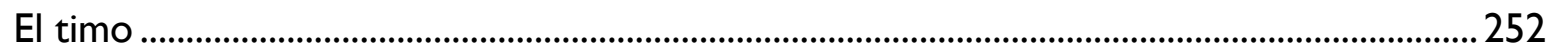

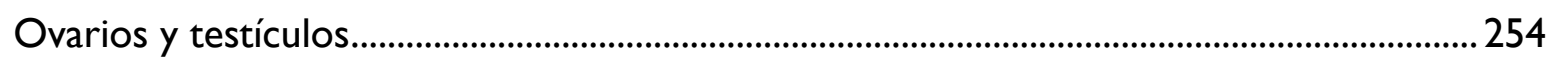

Hiperplasia suprarrenal congénita......................................................................................258

Trastornos de la glándula tiroides ..........................................................................................26

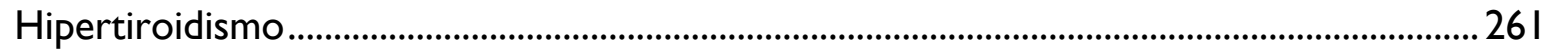

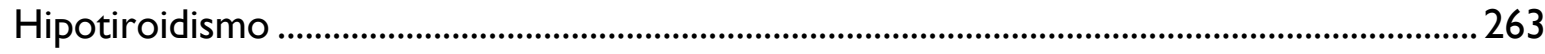

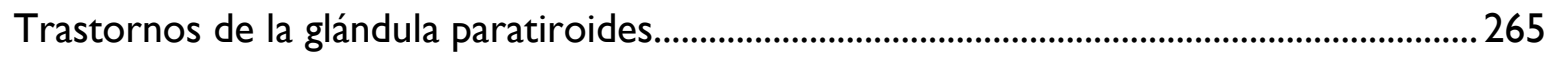

Trastornos de la glándula suprarrenal..................................................................................26

Trastornos de los islotes pancreáticos ...............................................................................2.

Razones por las que se realiza el examen ................................................................ 274

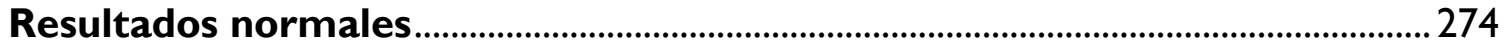




\section{Sistema Genito - Urinario y Endocrino}

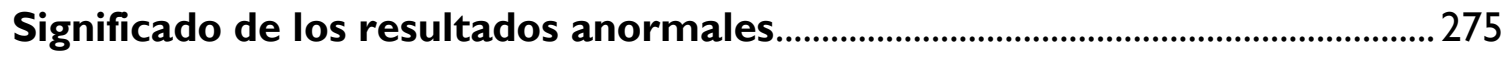

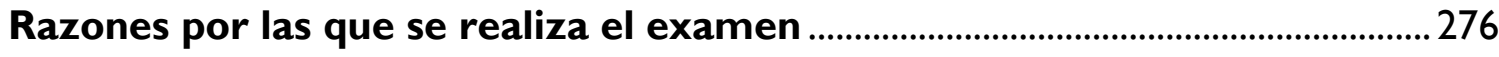

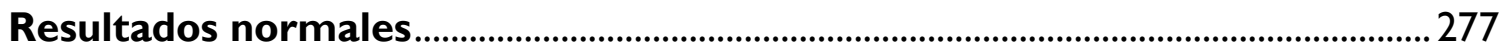

Significado de los resultados anormales....................................................................27

TIROIDES

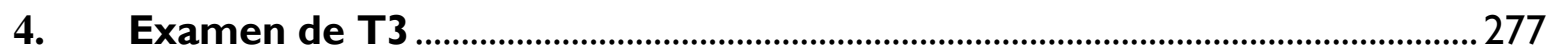

Razones por las que se realiza el examen .................................................................. 278

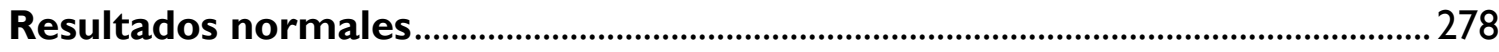

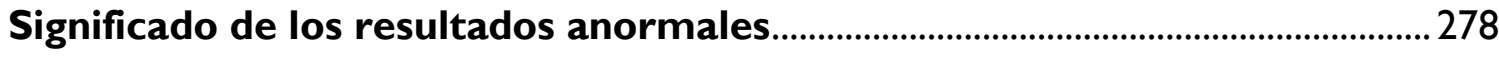

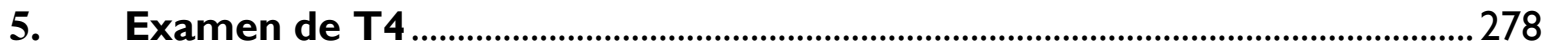

Razones por las que se realiza el examen .................................................................279

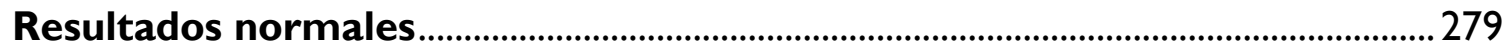

Significado de los resultados anormales........................................................................2

6. Examen de la hormona estimulante de la tiroides (TSH) ............................28

Razones por las que se realiza el examen .................................................................. 280

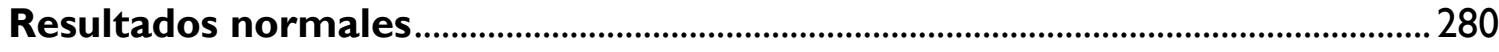

Significado de los resultados anormales..................................................................... 28 I

7. Anticuerpos microsómicos antitiroideos (ANTI TPO) ………………….....28

Razones por las que se realiza el examen ............................................................. 282

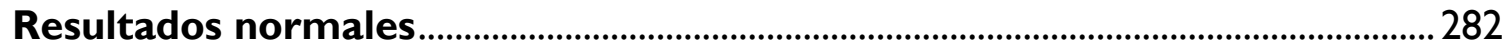

8. Examen de hormona paratiroidea (PTH) en la sangre..................................283

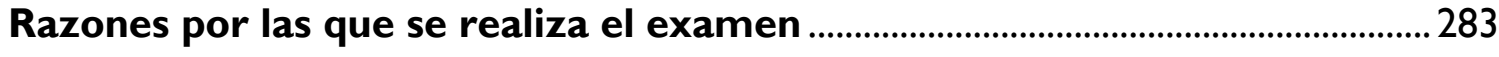

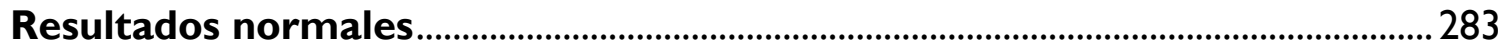




\section{Sistema Genito - Urinario y Endocrino}

Significado de los resultados anormales...................................................................28

9. Examen de estimulación con corticotropina ……………………………….......28

Razones por las que se realiza el examen .................................................................28

Significado de los resultados anormales....................................................................28

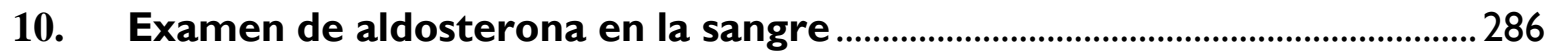

Razones por las que se realiza el examen ...................................................................28

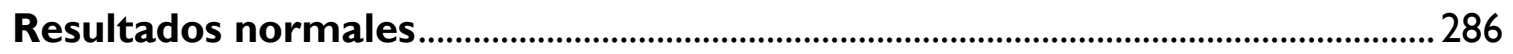

Significado de los resultados anormales....................................................................28

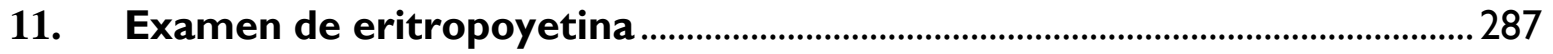

Razones por las que se realiza el examen ................................................................28

Resultados normales ....................................................................................................28

Significado de los resultados anormales...................................................................28

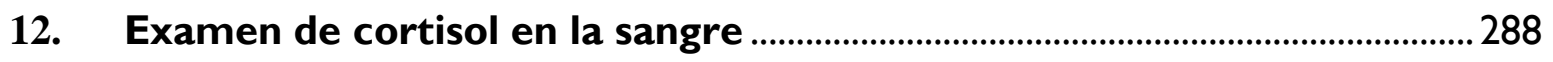

Razones por las que se realiza el examen ...............................................................28

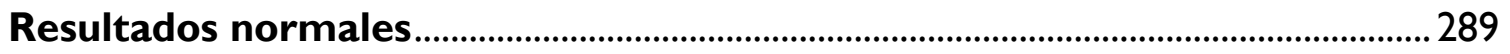

Significado de los resultados anormales....................................................................289

13. Examen de renina en la sangre ......................................................................... 289

Razones por las que se realiza el examen ................................................................290

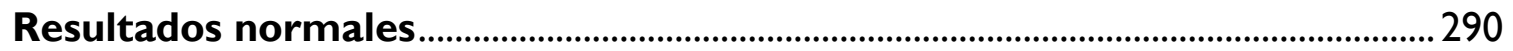

Significado de los resultados anormales...................................................................290

14. Hormona Folículo estimulante FSH en la sangre.............................................29 I

Resultados normales..................................................................................................... 29I

Significado de los resultados anormales...................................................................229 


\section{Sistema Genito - Urinario y Endocrino}

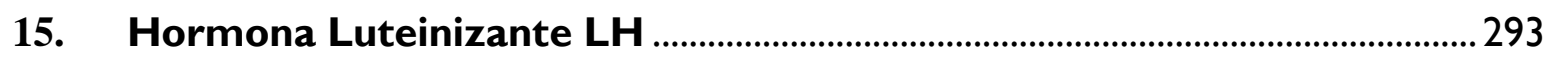

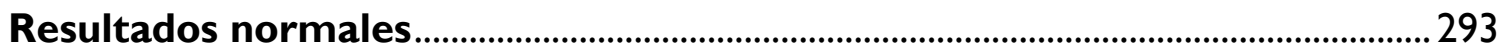

Significado de los resultados anormales....................................................................... 293

16. Examen de sangre de glucagón ………………………………………………........ 294

Razones por las que se realiza el examen ................................................................2 294

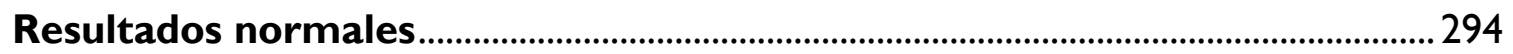

Significado de los resultados anormales ...................................................................... 295

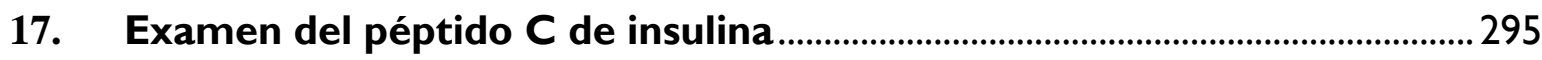

Razones por las que se realiza el examen .................................................................2 295

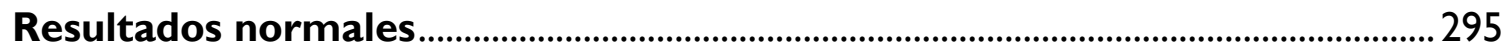

Significado de los resultados anormales...................................................................... 295

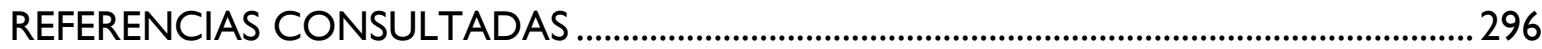

I4. Redacción Fisaude. (2009). Glándulas Tiroides. Hipotiroidismo. Recuperado a partir de http://blog.fisaude.com/nutricion/nutricion-profesional/glandulastiroides/Hipotiroidismo.html. 297

17. Stephan, S. (2004). Lo Esencial En Sistema Endocrino y Aparato Reproductor. Editorial: Elsevier, segunda edición. España................................................................................ 298

18. Stephan, S. (2004). Lo Esencial En Sistema Endocrino y Aparato Reproductor. Editorial: Elsevier, segunda edición. España. 298 
rio y Endocrino

Prolegómeno 


\section{Sistema Genito - Urinario y Endocrino}

\section{Prolegómeno}

El origen, reproducción y vida del ser humano constituyen procesos complejos que requieren de un estudio profundo para comprenderlos en atención a la gran importancia que tienen cada uno durante el desarrollo humano. Tanto la mujer como el hombre son partícipes de cambios físicos y psicológicos distintos que diferencian a unos de otros y los hace particulares.

En este sentido, el presente libro expone todos aquellos componentes anatómicos y fisiológicos urogenital- endocrino que, tanto en lo interno como en lo externo del cuerpo, provocan transformaciones y contribuyen al crecimiento y a la evolución de los individuos. Por ende, se tratan aspectos como el aparato reproductor femenino, aparato reproductor masculino, los métodos anticonceptivos, posibles patologías o trastornos de los órganos genitales y otros que pueden ayudar a educar sexualmente la sociedad.

Hoy en día, tanto jóvenes como adultos tienen acceso directo al tema de la sexualidad debido a los distintos medios tecnológicos que proveen información sobre el mismo; sin embargo, no todos proporcionan un contenido que, de forma pedagógica instruyen adecuadamente al individuo, sino tratan temas que desvían la atención hacia el sexo irresponsable. Del mismo modo, en algunas familias aún se percibe el tema del sexo y la sexualidad como temas tabú, lo cual constituye una barrera para entender tales aspectos como realidades normales que forman parte de la vida del hombre. No obstante, este tipo de percepción debe cambiar.

Por tal razón, es necesario generar tratados como el expuesto en este texto digital para ofrecer al público una visión global que conduzca al lector a comprender sus cambios corporales desde el punto de vista físico, sexual y psicológico de forma sencilla e inteligible; es decir, que permita al ser humano conocerse a sí mismo y romper con el tabú que aún pueda existir en algunas sociedades. 


\section{Sistema Genito - Urinario y Endocrino}

En atención a lo anterior, este libro también abarca temáticas como problemas renales, las enfermedades en embarazadas y trastornos hipertensivos gestacionales cuyos síntomas requieren ser conocidos por el ser humano a fin de tener conciencia de los mismos y reconocerlos en el momento en el cual se puedan presentar.

En términos generales, todos los temas tienen su enfoque en la salud y la vida de los seres humanos, los cuales son de suma relevancia por cuanto evidencian no sólo la transformación de los individuos como seres sexuales y reproductores sino también como preventivos en casos de patologías desconocidas e imprevistas.

\section{Dr. Reinaldo Velasco}




\section{Sistema Genito - Urinario y Endocrino}

\section{Prolegomenon}

The origin, reproduction and life of the human being constitute complex processes that require a deep study to understand them in attention to the great importance that each one has during human development. Both women and men have different physical and psychological changes that differentiate among them and make them unique.

In this sense, this book exposes all those urogenital-endocrine, anatomical and physiological components that both internally and externally cause transformations and contribute to the individuals' growth and evolution. Therefore, aspects such as the male reproductive system, contraceptive methods, pathologies or disorders of the genetic organs, and others are treated to educate society sexually.

Today, both young people and adults have direct access to the topic of sexuality due to the different technological means that provide information about it. However, not all of them offer content that instructs the individual adequately and pedagogically, but rather deals with issues that divert people's attention to irresponsible sex. In the same way, in some families, sex and sexuality are still perceived as taboo subjects, which constitute a barrier to understanding such aspects as normal realities that are part of man's life. Nevertheless, this type of perception must change.

For this reason, it is necessary to generate treatises like the one exposed in this digital text to offer the public a global vision that leads the readers to understand their bodily changes from the physical, sexual and psychological point of view in a simple and intelligible way; to be exact, a perspective that allows the human beings to know themselves and to break with the taboo that may still exist in some societies.

In view of the above, this book also covers topics such as kidney problems, diseases in pregnant women and gestational hypertensive disorders whose symptoms must be known by humans in order to be aware of them and recognize them at the moment in which they may be present. 


\section{Sistema Genito - Urinario y Endocrino}

In general terms, all the topics have their focus on the health and life of human beings, which are of great relevance because they show not only the transformation of individuals as sexual and reproductive beings but also as preventive in cases of unknown and unforeseen pathologies.

\section{Dr. Reinaldo Velasco}




\section{Sistema Genito - Urinario y Endocrino}

\section{A MODO DE INTRODUCCIÓN}

\section{El aparato reproductor a lo largo de la vida}

El sexo del bebe se determina muy pronto en el desarrollo fetal, más adelante durante la adolescencia, se produce un nuevo crecimiento cuando la actividad hormonal, favorecida por el cerebro y los órganos reproductores, estimula cambios drásticos en el cuerpo y en la maduración del aparato reproductor. Esto hace posible la reproducción. En el hombre los órganos reproductores funcionan a lo largo de toda la vida, en la mujer hasta que alcanza la menopausia alrededor de los 45-55 años.

Tras el desarrollo inicial de los órganos reproductores en el feto, se producen muy pocos cambios hasta que el niño alcanza la pubertad, habitualmente en la adolescencia. Al final de la vida, el aparato reproductor se vuelve a transformar, sobre todo en las mujeres, cuya fertilidad cesa y se atrofian sus órganos reproductores. Los hombres experimentan menos cambios en su rendimiento sexual, como eyaculaciones menos potentes y reducción de su esperma, lo que disminuye su fertilidad.

\section{Desarrollo del aparato reproductor}

El sexo de un bebé viene determinado por el tipo de cromosomas sexuales que contiene el ovulo fecundado. A las doce semanas de gestación, los órganos reproductores, tantos externos como internos, están completamente formados.

Entre la semana decimosexta y décimo octava, son los suficientemente grandes como para que en una ecografía se pueda distinguir el sexo del feto a pesar de que su detección solamente puede determinarse con exactitud mediante una amniocentesis.

\section{Desarrollo inicial}

Durante las primeras semanas de vida del embrión, tienen lugar el desarrollo de los órganos sexuales principales, conocidos como gónadas. Las gónadas se desarrollan a partir del mesodermo. En la sexta semana de gestación, aparecen como unas protuberancias próximas a los conductos de la zona baja del abdomen que desembocan en el seno urogenital. Hasta aproximadamente la séptima semana de gestación, las gónadas primitivas tienen el potencial de diferenciarse tanto en testículos como en ovarios, dependiendo de 


\section{Sistema Genito - Urinario y Endocrino}

si el feto dará lugar a un hombre o a una mujer.

Los genitales externos se desarrollan de una forma idéntica en ambos sexos hasta aproximadamente la octava semana del embarazo. Hasta ese momento, todos los embriones tienen una región elevada llamada tubérculo genital, un punto entre el trasero y el cordón umbilical. Rodeando esta fosa aparecen un par de pliegues uretrales y un par de pliegues labios escrotales.

\section{Desarrollo del hombre}

$\mathrm{Si}$ hay un cromosoma $\mathrm{Y}$, el feto se desarrolla como hombre. Existe un gen en el cromosoma $Y$, conocido como SRY (región determinante del sexo del cromosoma $Y$, que estimula la producción de testosterona. En el tejido gonadal de los embriones masculinos aparecen células que tienen un cromosoma $X$ y uno $Y$, la gonadotropina coriónica humana (hCG) una hormona producida por la placenta, estimula a las células endocrinas primitivas para que segreguen la hormona sexual masculina testosterona, que provoca que se desarrollen los órganos reproductores masculinos externos e internos. El pene, por ejemplo, se genera a partir de una parte del tubérculo genital.

\section{Desarrollo de la mujer}

$\mathrm{Si}$ existen dos cromosomas $\mathrm{X}$, el feto se desarrolla como mujer. Esto se produce principalmente debido a la ausencia del gen RRY y a la falta de las hormonas (testosterona y DHT) que estimulan en el hombre por la presencia del cromosoma Y. La ausencia de estas hormonas permite el desarrollo de los órganos reproductores femeninos internos y externos.

\section{Crecimiento del aparato reproductor}

Cuando nace el bebe, sus órganos reproductores están completamente formados, en un recién nacido, los testículos acostumbran a estar alojados en el escroto, aunque también es posible que se encuentre en la ingle y que desciende más adelante cuando el niño crezca. Una niña recién nacida puede tener una ligera secreción vaginal transparente o rosada, es absolutamente inicua y desaparece sin tratamiento. En las primeras semanas de vida los órganos reproductores experimentan una breve aceleración del crecimiento, 


\section{Sistema Genito - Urinario y Endocrino}

después de la cual permanecen prácticamente inalterados hasta la pubertad que aparece en la segunda década de la vida. Inmediatamente después del nacimiento, los pechos del recién nacido pueden hinchados debido al descenso de estrógenos de la madre y a la liberación de la hormona prolactina en la glándula pituitaria del bebe.

La pubertad se produce cuando los órganos sexuales aumentan de tamaño y maduran, haciendo posible la reproducción. Durante este tiempo también aparecen las características sexuales secundarias, como el bello facial en los hombres y el aumento de tamaño del pecho de las mujeres. La pubertad acostumbra a empezar al inicio de la segunda década de vida sobre los 12 y 14 años en los niños, y los 10 y 12 en las niñas. En ambos sexos se inicia cuando el hipotálamo comienza a secretar la hormona liberadora de gonadotropina. Esta hormona a su vez estimula a las glándulas endocrinas para que secreten otras como la hormona folículo estimulante y la hormona latinizante.

Cuando las gónadas reciben $\mathrm{FSH}$ y $\mathrm{LH}$, producen las hormonas sexuales estrógenos y testosterona, esta última estimula la aceleración de crecimiento, aumentando la altura y el peso. La mayor actividad hormonal también hace que las glándulas sebáceas sean más dinámicas, produciendo una piel grasa, espinillas y una mayor secreción de sudor. Esta considerable cantidad de hormonas en el organismo puede provocar además cambios bruscos de humor y estrés emocional.

\section{Pubertad en el niño}

En los niños, la pubertad acostumbra a empezar sobre los 12-14 años de edad, los testículos comienzan a producir testosterona, que estimula a las células sustentaculares (o de sertoli) a que maduren y a que, a su vez, produzcan espermatozoides. Los testículos y el escroto aumentan de tamaño, y el pene se alarga y se engrosa. Habitualmente alcanza el tamaño adulto unos dos años después del inicio de la pubertad. A medida que los órganos sexuales empiezan a madurar, las erecciones se hacen más frecuentes, y el niño experimenta su primera eyaculación de semen, que no contiene espermatozoides. Normalmente esto sucede entre los 12 y 14 años, pero la edad exacta viene determinada habitualmente por una combinación de factores físicos, culturales y psicológicos. 


\section{Sistema Genito - Urinario y Endocrino}

La testosterona también estimula el crecimiento del pelo alrededor de los genitales y en la cara, las axilas y otras partes del cuerpo. El vello púbico aparece en la base del pene. Al principio los pelos son rectos, pero se vuelven más ásperos y rizados a medida que progresa la pubertad. El vello púbico llega a cubrir la base del pene, y alcanza la parte superior de las piernas y el ano. A menudo, durante la pubertad, el aspecto del niño cambia, puesto que se reduce parte de su grasa corporal y sus músculos aumentan de tamaño. Se le ensanchan los hombros y la nuez de Adán, que es una parte de la laringe, se hace mayor, provocando que su voz sea más profunda.

Las glándulas sudoríparas apocrinas empiezan a producir un sudor más espeso que antes, que contiene proteínas y sustancias grasas así como agua y otros residuos. A medida que las bacterias descomponen el sudor, se despide un olor característico. Los niños comienzan a notar que tienen que lavarse con mayor frecuencia para evitar su olor corporal. Los cambios de la pubertad acostumbran a completarse a una edad entre los 19 y los 21 años.

\section{Pubertad en la niña}

En las niñas, la pubertad acostumbra a empezar sobre los 10-12 años de edad, aunque esto varía considerablemente de una persona a otra. La hormona $\mathrm{GnRH}$, segregada por el hipotálamo, estimula la producción de FSH y LH de la pituitaria, provocando que los ovarios aumenten de tamaño y elaboren la hormona llamada estrógeno, que se libera al torrente circulatorio y se distribuye por todo el cuerpo. El estrógeno estimula el crecimiento del útero y de las trompas uterinas. El útero aumenta de tamaño y se dobla hacia adelante por encima de la vejiga. Los estrógenos incrementan el riego sanguíneo hacia el útero y engruesan el endometrio. Cuando los ovarios producen el primer ovulo secundario, el endometrio está preparado para recibirlo, en caso de que sea fecundado. La vagina se alarga y ensancha, y el cuello uterino, en la abertura del útero, empieza a producir moco.

El cambio más espectacular que se produce en la pubertad de la chica es la aparición de la menstruación. El primer periodo menstrual se conoce como menarquia, y habitualmente 


\section{Sistema Genito - Urinario y Endocrino}

se presenta a una edad entre los II y los 14 años. Los periodos acostumbran a ser una de las últimas características que se manifiestan en la pubertad y marcan el inicio del ciclo de ovulación mensual, aunque en la mayoría de las niñas los primeros ciclos menstruales son anovulatorios, lo que significa que el ovario no genera ningún óvulo secundario. La aparición de los periodos suele producirse dependiendo del peso del cuerpo, y no se inicia hasta que la niña pesa alrededor de unos 45 kilos y su cuerpo contiene por lo menos de 17 por ciento de grasa. Durante el siglo $X X$, la edad de la menarquia ha descendido unos tres años en la mayoría de los países desarrollados. Se cree que esto es debido a una mejor salud u nutrición, lo que hace que las niñas alcancen su límite de peso a una edad cada vez más joven.

El estrógeno estimula el crecimiento de los pechos (conocido como brote de los pechos) aproximadamente a una edad entre los 9 y los 13 años, aunque varía de una persona a otra. Cada uno de los pechos puede crecer a una velocidad diferente, pero cualquier diferencia de tamaño suele desaparecer cuando la chica alcanza su total madurez sobre los 16 años. El estrógeno también estimula la aparición del vello axilar, y el ensanchamiento de las caderas.

Además es el responsable de la aceleración del crecimiento que se produce antes en las chicas que en los chicos. El vello púbico, estimulado igualmente por el estrógeno, aparece primero a lo largo de los bordes de la vulva. Acostumbra a ser más largo y oscuro que el resto del cuerpo. A medida q progresa la pubertad, va haciéndose más áspero y rizado, cubriendo un área triangular por encima del pubis. También puede parecer vellos en otras partes del cuerpo, como en las axilas y sobre las piernas, a pesar de que no es un pelo tan grueso como el de los chicos. En la chica la pubertad se completa normalmente entre los 17 y los 19 años.

\section{Crecimiento del pecho}

Antes de la pubertad, los pechos de una chica son similares a los de un chico, a medida que el estrógeno fluye por el cuerpo de la chica, se estimulan los pechos y empiezan a crecer desarrollando su capacidad de producir leche. Cuando sobrevienen estos cambios, 


\section{Sistema Genito - Urinario y Endocrino}

algunas chicas pueden sentir dolor en el pecho $\circ$ una cierta sensibilidad. Aproximadamente a los 9 años, empiezan a aparecer los primeros cambios externos:

El área de alrededor del pezón comienza a hincharse a medida q se va depositando grasa bajo la piel. Los pechos adquieren la forma de un pequeño cono cuando inician su desarrollo las primeras glándulas mamarias (de leche), y se oscurecen las aureolas de los pezones.

Luego el propio pecho se va haciendo mayor y se curva suavemente. Las glándulas mamarias siguen desarrollándose en el interior del pecho preparándose para poder alimentar a un bebé. Las glándulas no producen leche hasta que la mujer no acaba de tener un hijo. Durante la lactancia la leche se segrega en unos 15-20 glóbulos de glándulas mamarias, y circula por los conductos lácteos hasta el pezón. En ese momento las glándulas aumentan de tamaño, pero después de la lactancia los pechos regresan adquiriendo más o menos la misma forma que antes. Después de la menopausia, los pechos y las glándulas que contienen acostumbran de reducir de tamaño.

\section{El acelerón del crecimiento}

Con frecuencia el acelerón del crecimiento es el primer signo externo de que empieza la pubertad. Tanto los estrógenos como la testosterona tienen un efecto directo sobre los osteoblastos del hueso, estimulándolos a producir hueso a una velocidad mayor y, por lo tanto, provocando un crecimiento súbito en la longitud de los huesos y de las vértebras. Esto es lo que caracteriza el típico estirón del crecimiento, que sucede cerca del inicio de la pubertad. Paradójicamente, la testosterona y los estrógenos también inhiben el crecimiento óseo al final de la adolescencia, finalizando el crecimiento rápido, y pasando a una fase sin crecimiento óseo que dura toda la vida, a base de fundir las epífisis óseas. Durante el estirón del crecimiento, los chicos pueden aumentar hasta $9,5 \mathrm{~cm}, y$ las chicas hasta $8,5 \mathrm{~cm}$ en un año. Los músculos también desarrollan su tamaño hasta alcanzar la talla adulta, $y$ en el caso de las chicas, se deposita grasa por debajo de la piel para generar las curvas propias de su silueta. Los chicos alcanzan la altura máxima a una edad comprendida entre los 12 y los 17 años y las chicas entre los 10 y 13 años. En la edad adulta, los 


\section{Sistema Genito - Urinario y Endocrino}

hombres poseen un $50 \%$ más de musculatura y masa ósea que las mujeres, quienes a su vez tienen el doble de grasa corporal que los hombres.

\section{Cambios emocionales en la pubertad}

Durante la pubertad, los cambios físicos se acompañan de una maduración de la mente. Esta etapa puede provocar al chico una considerable confusión y ansiedad sobre las transformaciones que se producen en su cuerpo. Los cambios físicos, a veces bastante espectaculares, suelen promover y aumentar la autoconciencia de preocupación acerca de su aspecto externo. La aparición del acné u otros efectos colaterales de la pubertad, a veces ocasionan estrés. La actividad hormonal también posibilita alteraciones de humor, pero en cuanto han finalizado los cambios físicos, desaparecen también los del humor.

\section{Inicio precoz y tardío de la pubertad}

En casos muy raros, la pubertad puede aparecer mucho antes o mucho más tarde de lo esperado. Se considera una pubertad precoz la que se presenta antes de los 8 años en las chicas y antes de los 10 en los chicos. Es hasta cinco veces más frecuente en las chicas que en los chicos. La mayoría de casos parecen ser de tipo idiopático, pero se cree que sucede en determinadas familias. Otras causas de pubertad precoz incluyen un tumor en el hipotálamo. En algunas personas puede que se desarrollen los pechos o aparezca vello púbico sin que esté produciéndose una auténtica pubertad.

En ambos sexos es factible una aparición tardía de la pubertad, en la que ésta aún no se ha manifestado a una edad entre 14-16 años. Puede producirse por causa natural, o debido a diversos trastornos, como algunas enfermedades crónicas graves, deficiencias hormonales o anomalías cromosómicas. En las chicas la menstruación y otros aspectos del desarrollo reproductor pueden retrasarse si el nivel de grasa corporal no es el adecuado, por ejemplo si padece algún trastorno alimentario, o realiza grandes esfuerzos físicos agotadores, como gimnasia, atletismo o danza profesional o de competición.

\section{La menopausia masculina}

Hay médicos que dicen que a medida que el hombre envejece, su cuerpo produce menos testosterona, provocando en él un proceso similar a la menopausia femenina. Los 


\section{Sistema Genito - Urinario y Endocrino}

síntomas de la menopausia masculina incluyen problemas para alcanzar o mantener una erección, menos cantidad de semen en las eyaculaciones, reducción del vello corporal, aumento de peso (en especial alrededor de la cintura), sudores nocturnos, algunos sofocos ocasionales, fatiga, falta de vigor, irritabilidad y ligera depresión.

Se dice, aunque no se ha demostrado, que la concentración de proteína unida a las hormonas sexuales aumenta en los hombres de edad avanzada, lo que hace que haya menos testosterona circulante por el cuerpo. Otra teoría es que los tejidos corporales, que normalmente responden a la acción de la testosterona, se hacen más resistentes a ella, de tal manera que se necesita más cantidad para alcanzar el mismo efecto. Algunos hombres que padecen problemas que pueden ir asociados con la menopausia masculina, se les ofrece una terapia de sustitución hormonal, aplicando testosterona. Sin embargo es posible tomar medidas de autoayuda, mejorando la forma física general, dejando de fumar

y reduciendo la ingestión de alcohol, además de hacer ejercicio, por lo menos, tres veces por semana y descansando todo lo necesario, lo que en conjunto puede ser muy útil para afrontar los síntomas de la menopausia masculina.

\section{Envejecimiento y el aparato reproductor}

Igual como sucede con todos los sistemas del organismo, el aparato reproductor cambia con la edad. En los hombres la función sexual puede verse afectada por la edad o por alguna enfermedad de otra parte del cuerpo. En las mujeres se produce una transformación mucho más espectacular cuando la menopausia anuncia el final de la capacidad reproductora. Los cambios emocionales y físicos afectan a otros sistemas corporales al mismo tiempo.

\section{Cambios en el varón}

En el aparato reproductor masculino se producen menos cambios que en el femenino, $y$ los hombres continúan siendo fértiles mientras envejecen, con frecuencia hasta que alcanzan los 80-90 años. Sin embargo, después de los 50, a causo del descenso de los niveles de testosterona, cada vez tardan más en alcanzar una erección. Determinados trastornos circulatorios también pueden ser la causa de los problemas de erección. Si los 


\section{Sistema Genito - Urinario y Endocrino}

hombres dejan de ser sexualmente activos a medida que envejecen, esto puede llegar a una disminución de libido y de potencia sexual. Los que se mantienen sexualmente activos a menudo, notan muy poco declive en su vida sexual.

\section{Cambios en la mujer}

La menopausia, señalada por el final del periodo menstrual, acostumbra a aparecer entre los 45 y los 55 años, y es el momento en que la mujer cesa de ovular y ya no puede quedar embarazada. Los ovarios dejan de responder a las hormonas gonadotropinas producidas por la glándula pituitaria $y$, en consecuencia, obtienen menos estrógeno y progesterona, que facilitarían la reproducción. Este proceso no sobreviene de forma inmediata en cuanto empieza la menopausia, sino que puede aparecer a lo largo de varios años. La menopausia se suele describir en dos etapas: la perimenopausia y la postmenopausia. Puesto que el proceso de finalización de la etapa reproductiva requiere bastante tiempo, la mayoría de médicos recomiendan que la mujer siga tomando anticonceptivos hasta que no haya tenido ninguna hemorragia durante dos años si tiene menos de 50, y durante un año si tiene más de 50.

La perimenopausia: cuando los niveles de hormonas empiezan a fluctuar en el cuerpo de la mujer, se conoce como perimenopausia o climaterio. El primer síntoma de que sucede algo así, suele ser que los periodos se hacen irregulares, y esto puede continuar durante varios años. Aproximadamente el 80 por ciento de las mujeres también acostumbran a experimentar sofocos, porque el hipotálamo que controla la temperatura corporal, funciona mal.

Parece que existe una conexión entre esta falta de regulación de temperatura y un incremento de la hormona luteinizante $(\mathrm{LH})$, una de las hormonas que controla el ciclo ovárico en las mujeres. Es frecuente que los niveles de $\mathrm{LH}$ aumenten antes y durante la menopausia. Durante un sofoco, la cara, el cuello y el área del pecho se vuelven rojos y calientes; la mujer además suele sudar profusamente, y notar una marcada aceleración del ritmo cardiaco acompañada de mareos. La falta de estrógenos puede también provocar sudores nocturnos (que a veces ocasionan trastornos del sueño), cansancio, dolores de 


\section{Sistema Genito - Urinario y Endocrino}

cabeza, depresión, irritabilidad y perdida del libido.

Durante la propia menopausia, la disminución de los niveles de estrógeno provoca que se segregue menos moco en las paredes del cuello uterino o de la vagina; ésta permanece excesivamente seca y las relaciones sexuales pueden ser dolorosas. Una manera de evitarlo suele ser el uso de un lubricante hidrófilo. La caída de los niveles de estrógeno también hace que las paredes de la vagina se adelgacen y sean menos elásticas, provocando que la vagina sea más sensible a la infección. El cese de la función ovárica tiene como consecuencia que los ovarios se atrofien.

La reducción de estrógenos tiene efecto sobre otras partes del cuerpo, además del aparato reproductor. La vejiga y la uretra se hacen más delgadas y menos elásticas, lo que a veces provoca la necesidad de orinar con una mayor frecuencia. La menopausia puede desencadenar cambios del metabolismo, aumentando la vulnerabilidad de las mujeres posmenopáusicas a los problemas cardiovasculares como las enfermedades cardiacas. Los estrógenos tienen un papel importante en la regulación de la masa ósea, por lo que en las perimenopausia se acelera la pérdida ósea, así como inmediatamente después de la menopausia. Algunas mujeres pueden llegar a desarrollar osteoporosis.

La posmenopausia: cuando se han detenido los ciclos menstruales, se dice que ha empezado la posmenopausia. Este periodo continúa durante el resto de la vida de la mujer. Durante los primeros años de esta etapa, una mujer puede seguir experimentando síntomas que empezaron en la perimenopausia como sofocos o sudores nocturnos, pero acostumbran a desaparecer a los pocos años. Otros síntomas, como las infecciones del tracto urinario o de la vagina, pueden hacerse más frecuentes.

\section{Terapia de sustitución hormonal}

Si una mujer experimenta síntomas graves durante la menopausia, o si tiene un elevado riesgo de desarrollar una osteoporosis o cualquier otro problema relacionado en la reducción de estrógenos, puede recibir una terapia de sustitución hormonal (TSH). La TSH contiene estrógenos y progesterona. La progesterona reduce la probabilidad de desarrollar cáncer uterino, que puede ser un efecto lateral cuando solamente se toman 


\section{Sistema Genito - Urinario y Endocrino}

estrógenos.

\section{Recomendaciones}

Una vez realizada la lectura y comprendido el material, se sugiere extraer las ideas principales, profundizar en su estudio, revisar la bibliografía sugerida para tal fin, se pueden incluir nuevas fuentes de considerarse necesario. Prepare su informe para ser socializado en clases.

\section{BIBLIOGRAFÍA SUGERIDA}

1. Morales Martínez ME, Pedrón N. beta-Endorfinas y el aparato reproductor masculino [beta-Endorphins and the male reproductive system]. Ginecol Obstet Mex. 1999; 67:183187.

2. Covarrubias Alejandra A, Romero María Soledad. Anatomía del sistema reproductor femenino y masculino de Sinum cymba (Menke, 1828) (Gastropoda: Naticidae). Rev. biol. mar. oceanogr. 2009; 44 (3): 673-683.

3. Thornton K, Chervenak J, Neal-Perry G. Menopause and Sexuality. Endocrinol Metab Clin North Am. 2015;44(3):649-661. doi:10.1016/j.ecl.2015.05.009 Graziottin A, Leiblum SR. Biological and psychosocial pathophysiology of female sexual dysfunction during the menopausal transition.J Sex Med. 2005;2 Suppl 3:133-145. doi:10.1111/j.17436109.2005.00129.x

4. Purandare A, Co Ng L, Godil M, Ahnn SH, Wilson TA. Effect of hypothyroidism and its treatment on the IGF system in infants and children. J Pediatr Endocrinol Metab. 2003;16(1):35-42. doi:10.1515/jpem.2003.16.1.35

5. Bray I, Gunnell D, Holly JM, Middleton N, Davey Smith G, Martin RM. Associations of childhood and adulthood height and the components of height with insulin-like growth factor levels in adulthood: a 65-year follow-up of the Boyd Orr cohort. J Clin Endocrinol Metab. 2006;91(4):1382-1389. doi:10.1210/jc.2005-1722

6. Charmian AQ. Childhood-onset growth hormone deficiency: reassessment of GH status after completion of growth. Int J Clin Pract Suppl. $2002 ;(126): 8-13$.

7. Audí Parera L. Actualización del crecimiento del esqueleto humano y sus indicadores [Update on the human skeletal growth and its markers]. Med Clin (Barc). 2004; 123(12):463-465. doi:10.1016/s0025-7753(04)74556-x

8. Hernández Rodríguez M. El patrón de crecimiento humano. Factores que condicionan y regulan el crecimiento [The pattern of human growth. Factors conditioning and regulating growth]. An Esp Pediatr. 1992; 36 Suppl 50:9-18.

9. Nappi RE, Lachowsky M. Menopause and sexuality: prevalence of symptoms and impact on quality of life. Maturitas. 2009; 63(2):138-141. doi:10.1016/j.maturitas.2009.03.021 


\section{Sistema Genito - Urinario y Endocrino}

10. Kalmbach DA, Kingsberg SA, Roth T, Cheng P, Fellman-Couture C, Drake CL. Sexual function and distress in postmenopausal women with chronic insomnia: exploring the role of stress dysregulation. Nat Sci Sleep. 2019; 11:141-153. Published 2019 Aug 22. doi:10.2147/NSS.S213941

11. Prior JC. Progesterone for the prevention and treatment of osteoporosis in women. Climacteric. 2018;21(4):366-374. doi:10.1080/13697137.2018.1467400

12. Pickar JH. Progesterone. Climacteric. 2018;21(4):305. doi:10.1080/13697137.2018.1462910

13. Wu YV, Burnham WM. Progesterone, 5a-dihydropogesterone and allopregnanolone's effects on seizures: A review of animal and clinical studies. Seizure. 2018;63:26-36. doi:10.1016/j.seizure.2018.10.012 
Sistema Genito - Urinario y Endocrino

\section{Capítulo I}

Aparato reproductor masculino 


\section{Sistema Genito - Urinario y Endocrino}

\section{CAPÍTULO I \\ APARATO REPRODUCTOR MASCULINO}

\section{Funciones del aparato reproductor masculino}

I. Los testículos producen espermatozoides y la hormona sexual masculina, testosterona.

2. Los conductos transportan, almacenan y contribuyen a la maduración de los espermatozoides.

3. Las glándulas sexuales accesorias secretan la mayor parte del líquido que forma el semen.

4. El pene contiene la uretra y es la vía de paso para la eyaculación del semen y la excreción de la orina.

\section{Espermatogénesis}

En los seres humanos, la espermatogénesis dura entre 65 y 75 días.

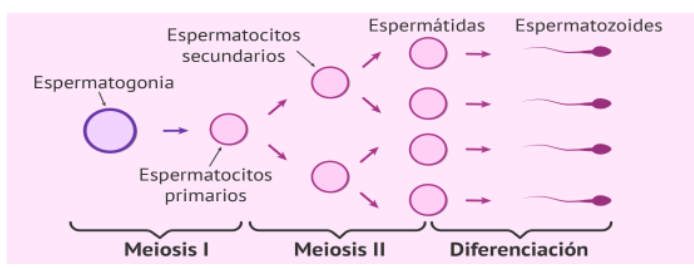

Comienza con la espermatogonia, que contiene un número diploide $(2 n)$ de cromosomas. Las espermatogonias son un tipo de células madre; cuando realizan meiosis, algunas espermatogonias permanecen cerca de la membrana basal del túbulo seminífero en un estado indiferenciado para servir como reservorio de células en futuras meiosis y subsiguiente producción de espermatozoides. Las restantes pierden contacto con la membrana basal, se introducen entre las uniones estrechas de la barrera hematotesticular, sufren cambios en su desarrollo y así se diferencian en espermatocitos primarios. Éstos, como las espermatogonias, son diploides (2n); es decir, tienen 46 cromosomas. Poco después de su formación, cada espermatocito primario replica su ADN y luego inicia la meiosis. 


\section{Sistema Genito - Urinario y Endocrino}

Durante la meiosis I los pares homólogos de cromosomas se alinean sobre el eje ecuatorial de la célula, y tiene lugar el entrecruzamiento de genes (crossing-over). Luego, el huso meiótico tracciona un cromosoma (duplicado) de cada par hacia el polo opuesto de la célula en división. Las dos células formadas en la meiosis I se denominan espermatocitos secundarios. Cada uno de ellos contiene 23 cromosomas, el número haploide. Cada cromosoma dentro del espermatocito secundario, sin embargo, está formado por dos cromátides (dos copias de ADN) aún unidas por el centrómero. No se producen posteriores replicaciones de ADN en los espermatocitos secundarios.

Durante la meiosis II los cromosomas se alinean en una única fila sobre el eje ecuatorial de la célula, y las dos cromátides de cada cromosoma se separan. Las cuatro células haploides que se forman luego de la meiosis II se llaman espermátides. Cada espermatocito, entonces, produce cuatro espermátides por medio de dos divisiones consecutivas. Durante la espermatogénesis, tiene lugar un proceso único. A medida que las células espermatogénicas proliferan, no logran completar la separación citoplasmática (citocinesis).

Las células permanecen en contacto por medio de puentes citoplasmáticos durante todo su desarrollo. Este patrón de desarrollo probablemente sea la causa de la producción sincrónica de espermatozoides en cualquier área del túbulo seminífero. También podría tener importancia para la supervivencia de las células, ya que la mitad de los espermatozoides contiene un cromosoma $X$ y la otra mitad, un cromosoma $Y$.

\section{Espermatozoides}

Cada día, alrededor de 300 millones de espermatozoides completan el proceso de espermatogénesis. Un espermatozoide mide alrededor de $60 \mu \mathrm{m}$ de largo y contiene distintas estructuras específicamente adaptadas para poder alcanzar y penetrar a un ovocito secundario

Las partes principales de un espermatozoide son la cabeza y la cola. La cabeza, aplanada y piriforme, mide 4-5 $\mu \mathrm{m}$ de largo. Contiene un núcleo con 23 cromosomas muy condensados. Cubriendo los dos tercios anteriores del núcleo se encuentra el acrosoma 


\section{Sistema Genito - Urinario y Endocrino}

(ákrons-, extremo; y -sóoma, cuerpo), una vesícula con forma de capuchón llena de enzimas que ayudan al espermatozoide a penetrar el ovocito secundario y así lograr la fecundación. Entre las enzimas, encontramos hialuronidasas y proteasas. La cola del espermatozoide se divide en cuatro partes: cuello, pieza intermedia, pieza principal y pieza terminal.

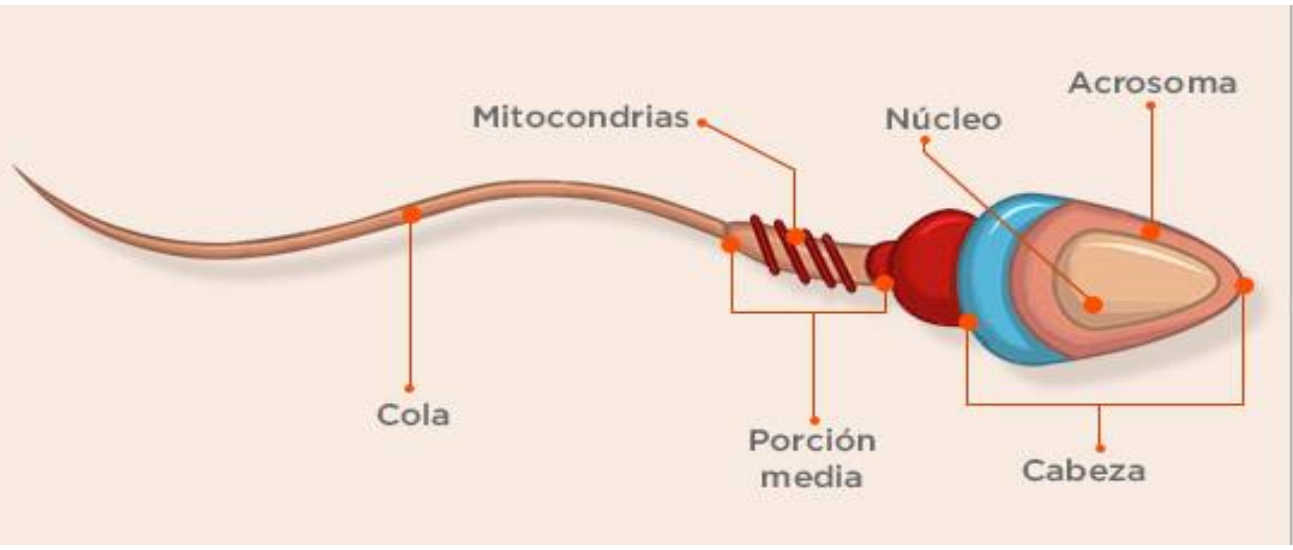

\section{Control hormonal de los testículos}

Los factores iniciadores se desconocen, pero al llegar a la pubertad, ciertas células neurosecretoras hipotalámicas incrementan la secreción de hormona liberadora de gonadotrofinas $(\mathrm{GnRH})$. Esta hormona, a su vez, estimula las células gonadotróficas en el lóbulo anterior de la hipófisis al aumentar la secreción de dos gonadotrofinas: la hormona luteinizante (LH) y la hormona foliculoestimulante (FSH).

La LH estimula las células de Leydig, localizadas entre los túbulos seminíferos, al secretar la hormona testosterona. Esta hormona esteroidea se sintetiza en los testículos a partir del colesterol y es el principal andrógeno. Al ser liposoluble, difunde fácilmente fuera de las células de Leydig hacia el líquido intersticial y luego a la sangre. Por un mecanismo de retroalimentación negativa, la testosterona inhibe la secreción de LH por parte de las células gonadotrópicas del lóbulo anterior de la hipófisis y la secreción de $\mathrm{GnRH}$, por parte de las células neurosecretoras hipotalámicas.

La FSH y la testosterona intervienen en forma sinérgica sobre las células de Sertoli, al 


\section{Sistema Genito - Urinario y Endocrino}

estimular la secreción de la proteína ligadora de andrógenos (ABP) hacia la luz de los túbulos seminíferos y hacia el líquido intersticial, alrededor de las células espermatogénicas. La ABP se une a la testosterona y mantiene su concentración elevada. La testosterona estimula los pasos finales de la espermatogénesis, dentro de los túbulos seminíferos. Una vez que se alcanza el grado de espermatogénesis requerido para cumplir las funciones reproductivas del hombre, las células de Sertoli liberan inhibina, una hormona proteica llamada así por su función inhibitoria sobre la secreción de FSH, por parte de la adenohipófisis.

I. Desarrollo prenatal. Antes del nacimiento, la testosterona estimula el patrón de desarrollo masculino de los conductos del aparato reproductor y el descenso de los testículos. La dihidrotestosterona estimula el desarrollo de los genitales externos y también se convierte en estrógenos (hormonas feminizantes) en el cerebro, que podrían desempeñar una función en el desarrollo de ciertas regiones del cerebro de los hombres.

2. Desarrollo de los caracteres sexuales masculinos. En la pubertad, la testosterona y la dihidrotestosterona son responsables del desarrollo y del crecimiento de los órganos sexuales masculinos y del desarrollo de los caracteres sexuales secundarios masculinos.

Los caracteres sexuales secundarios son los que diferencian a los hombres de las mujeres, pero no cumplen una función directa en la reproducción. Éstos incluyen: el crecimiento muscular y esquelético que dan como resultado una espalda ancha y una cintura angosta; crecimiento de vello púbico, facial y pectoral (dentro de los límites aportados por la herencia) y mayor cantidad de vello en otras partes del cuerpo; engrosamiento de la piel; aumento de la secreción de las glándulas sebáceas y crecimiento de la laringe, lo que produce el tono grave de la voz.

3. Desarrollo de la función sexual. Los andrógenos contribuyen al comportamiento sexual masculino y la espermatogénesis, como así también a la libido (impulso sexual), tanto en hombres como en mujeres. Recuerde que la 


\section{Sistema Genito - Urinario y Endocrino}

corteza suprarrenal es la principal fuente de andrógenos en la mujer.
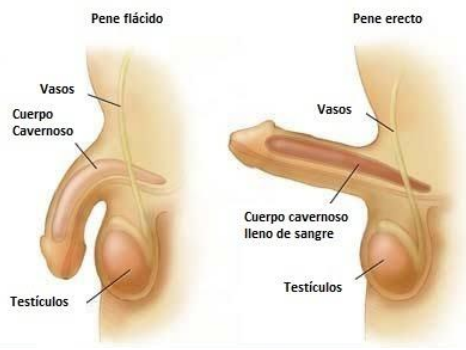

4. Estimulación del anabolismo. Los andrógenos son hormonas anabólicas; es decir, estimulan la síntesis de proteínas. Esto se evidencia en la mayor masa muscular y ósea que se observa en los hombres, con respecto a las mujeres.

\section{Conductos del aparato reproductor masculino}

El aparato reproductor masculino es, junto con el femenino, el encargado de la reproducción, es decir, de la formación de nuevos individuos. Los principales órganos externos son los testículos, el epidídimo, el pene y el escroto, el saco que envuelve los testículos. Los conductos deferentes y las glándulas accesorias son órganos internos. Los testículos producen espermatozoides y liberan a la sangre hormonas sexuales masculinas (testosterona). Un sistema de conductos que incluyen el epidídimo y los conductos deferentes almacenan los espermatozoides y los conducen al exterior a través del pene. En el transcurso de las relaciones sexuales se produce la eyaculación, que consiste en la liberación del líquido seminal o semen. El semen está compuesto por los espermatozoides producidos por los testículos y diversas secreciones de las glándulas sexuales accesorias, que son la próstata y las glándulas bulbouretrales.

\section{Pene}

Es el órgano copulador masculino, que interviene, además, en la excreción urinaria, está 


\section{Sistema Genito - Urinario y Endocrino}

formado por el cuerpo esponjoso y los cuerpos cavernosos, una de cuyas facultades es depositar el esperma durante el coito, y con ello lograr la fecundación del óvulo.

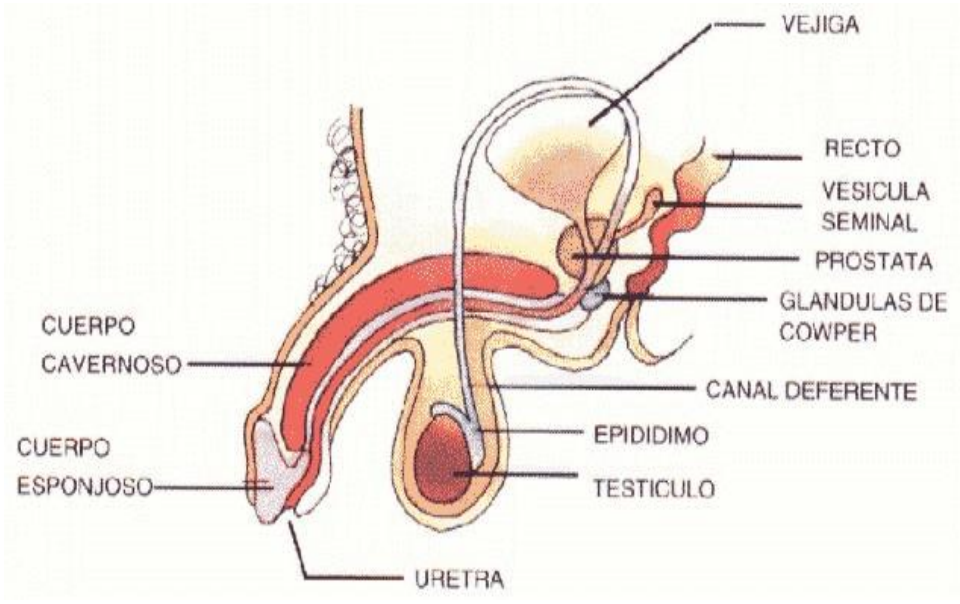

\section{Cuerpo esponjoso}

El cuerpo esponjoso es la más pequeña de las tres columnas de tejido eréctil que se encuentran en el interior del pene (las otras dos son los cuerpos cavernosos). Está ubicado en la parte inferior del miembro viril. El glande es la última porción y la parte más ancha del cuerpo esponjoso; presenta una forma cónica.

Su función es la de evitar que durante la erección, se comprima la uretra, conducto por el que son expulsados tanto el semen como la orina.

\section{Cuerpos cavernosos}

Los cuerpos cavernosos constituyen un par de columnas de tejido eréctil situadas en la parte superior del pene que se llenan de sangre durante las erecciones.

\section{Epidídimo}

El epidídimo se constituye por la reunión y apelotonamiento de los conductos seminíferos. Se distingue una cabeza, cuerpo y cola que continúa con el conducto deferente. Tiene aproximadamente $5 \mathrm{~cm}$ de longitud por $12 \mathrm{~mm}$ de ancho. Desde el punto de vista funcional, los conductos del epidídimo son los responsables tanto de la maduración como de la activación de los espermatozoides (los cuales requieren entre 10 y 14 días).

\section{Conductos deferentes}

Los conductos deferentes son un par de conductos rodeados de músculo liso, cada uno 


\section{Sistema Genito - Urinario y Endocrino}

de $30 \mathrm{~cm}$ de largo, aproximadamente, que conectan el epidídimo con los conductos eyaculatorios, intermediando el recorrido del semen.

\section{Órganos internos}

\section{Vesículas seminales}

Segrega un líquido alcalino viscoso que neutraliza el ambiente ácido de la uretra. En condiciones normales el líquido contribuye alrededor del $40 \%$ del semen. Las vesículas seminales son unas glándulas productoras de aproximadamente el $3 \%$ del volumen del líquido seminal situadas en la excavación pélvica. Detrás de la vejiga urinaria, delante del recto e inmediatamente por encima de la base de la próstata, con la que están unidas por su extremo inferior.

\section{Conducto deferente}

Los conductos deferentes o eyaculatorios son parte de la anatomía masculina; cada varón tiene dos de ellos. Comienzan al final de los vasos deferentes y terminan en la uretra. Durante la eyaculación, el semen pasa a través de estos conductos y es posteriormente expulsado del cuerpo a través del pene.

\section{Próstata}

La próstata es un órgano glandular del aparato genitourinario, exclusivo de los hombres, con forma de castaña, localizada enfrente del y a la salida de la vejiga urinaria. Contiene células parte del líquido seminal que protege y nutre a los espermatozoides contenidos en el semen.

\section{Uretra}

La uretra es el conducto por el que discurre la

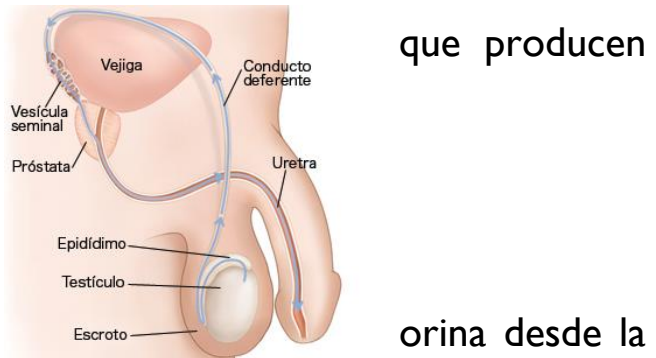
vejiga urinaria hasta el exterior del cuerpo durante la micción. La función de la uretra es excretora en ambos sexos y también cumple una función reproductiva en el hombre al permitir el paso del semen desde las vesículas seminales que abocan a la próstata hasta el exterior. 


\section{Sistema Genito - Urinario y Endocrino}

\section{Glándulas bulbouretrales}

Glándulas bulbouretrales, también conocidas como glándulas de Cowper, son dos glándulas que se encuentran debajo de la próstata. Su función es secretar un líquido alcalino que lubrica y neutraliza la acidez de la uretra antes del paso del semen en la eyaculación. Este líquido puede contener espermatozoides (generalmente arrastrados), por lo cual la práctica de retirar el pene de la vagina antes de la eyaculación no es un método anticonceptivo efectivo.

Al producirse la estimulación sexual, (visual, táctil, auditiva, olfativa o imaginada), fibras simpáticas provenientes de la porción sacra de la médula espinal inician y mantienen la erección, es decir, el aumento de tamaño y endurecimiento del pene. Las fibras parasimpáticas liberan y estimulan la producción local de óxido nítrico (NO). El NO produce la relajación de las fibras musculares lisas en las paredes de las arteriolas que nutren los tejidos eréctiles, lo que permite la dilatación de los vasos sanguíneos.

De esta forma, grandes cantidades de sangre ingresan en los tejidos eréctiles del pene. El NO también produce la relajación del músculo liso en los tejidos eréctiles, y aumenta así el tamaño de las sinusoides sanguíneas.

La combinación de flujo sanguíneo aumentado y la dilatación de las sinusoides sanguíneas dan como resultado la erección. La expansión de las sinusoides sanguíneas produce también la compresión de las venas que drenan el pene; el enlentecimiento del flujo sanguíneo contribuye a mantener la erección. El término priapismo se refiere a la erección persistente y habitualmente dolorosa de los cuerpos cavernosos del pene sin relación con el deseo sexual o la excitación. Este cuadro puede durar varias horas y se produce como resultado de anomalías en los vasos sanguíneos y los nervios, en general en respuesta a medicación utilizada para producir la erección en hombres con trastornos eréctiles. Otras causas son lesión de la médula espinal, leucemia, anemia de células falciformes y tumor pelviano.

\section{La eyaculación}

La liberación brusca de semen desde la uretra hacia el exterior, es un reflejo simpático 


\section{Sistema Genito - Urinario y Endocrino}

coordinado por la región lumbar de la médula espinal. Como parte de este reflejo, el esfínter de músculo liso en la base de la vejiga urinaria se cierra y, así, evita que la orina sea expulsada durante la eyaculación y que el semen ingrese en la vejiga urinaria. Incluso, antes de que la eyaculación se produzca, las contracciones peristálticas del epidídimo, del conducto deferente, de las vesículas seminales, de los conductos eyaculatorios y de la próstata impulsan el semen a la porción peneana de la uretra (uretra esponjosa).

Esto conduce a la emisión, que es la secreción de un pequeño volumen de semen antes de la eyaculación. La emisión también puede producirse durante el sueño (emisión o polución nocturna). La musculatura del pene (porciones bulbo esponjosa e isquiocavernosa y los músculos transversos superficiales del periné), inervada por el nervio pudendo, también se contrae durante la eyaculación

Una vez que la estimulación sexual del pene termina, las arteriolas que proveen la sangre a los tejidos eréctiles y al músculo liso del tejido eréctil se contraen, y disminuye el tamaño de las sinusoides. Esto alivia la presión en las venas tributarias del pene y permite que la sangre drene a través de ellas. En consecuencia, el pene vuelve a su estado flácido (relajado).

\section{Perineo masculino}

\section{Constitución músculo-aponeurótica}

Los 8 músculos perineales se disponen en tres planos: superficial, medio y profundo.

\section{Plano superficial}

Músculo esfínter externo del ano, músculo transverso superficial del periné contribuiría a la compresión del conducto anal interviniendo en el proceso defecatorio.

Músculo isquiocavernoso

Músculo bulbo esponjoso junto con el isquicavernoso intervienen en la erección del pene, pues mediante su contracción comprimen los órganos eréctiles sobre los que se insertan. El músculo de Houston, un fascículo del bulbo esponjoso, comprime la vena dorsal del pene contribuyendo también a mantener la erección evitando el retorno venoso de sangre. 


\section{Sistema Genito - Urinario y Endocrino}

\section{Escroto}

El escroto (bolsa), la estructura de sostén para los testículos, está compuesta por piel laxa y la fascia superficial que cuelga de la raíz (porción fija) del pene. Exteriormente, el escroto se ve como una única bolsa de piel separada en dos porciones laterales por un surco medio llamado rafe. En su interior, el septo o tabique escrotal divide al escroto en dos sacos, cada uno con un testículo. El tabique está formado por una fascia superficial y tejido muscular, el músculo dartos (de dartós, despellejado), que se compone de haces de fibras musculares lisas. La localización del escroto y la contracción de sus fibras musculares regulan la temperatura de los testículos. La producción normal de espermatozoides requiere una temperatura alrededor de $2-3^{\circ} \mathrm{C}$ por debajo de la temperatura corporal central que dentro del escroto es más baja, ya que éste se encuentra fuera de la cavidad pelviana.

\section{Testículos}

Los testículos son glándulas pares ovales ubicadas en el escroto, que miden $5 \mathrm{~cm}$ de largo y $2,5 \mathrm{~cm}$ de diámetro. Cada testículo tiene un peso de 10-15 gramos. Los testículos se desarrollan cerca de los riñones, en la porción posterior del abdomen y comienzan a descender hacia el escroto, a través de los conductos inguinales (pasajes en la pared abdominal inferior) durante la segunda mitad del séptimo mes del desarrollo fetal.

Contactar con el personal de laboratorio.

\section{BIBLIOGRAFÍA SUGERIDA}

I. Staub C, Johnson L. Review: Spermatogenesis in the bull. Animal. 2018;|2(sI):s27s35. doi:10.1017/SI75I73/II8000435

2. Hermo L, Pelletier RM, Cyr DG, Smith CE. Surfing the wave, cycle, life history, and genes/proteins expressed by testicular germ cells. Part I: background to spermatogenesis, spermatogonia, and spermatocytes. Microsc Res Tech. 2010;73(4):24I-278. doi:10.1002/jemt.20783

3. Suarez SS. Mammalian sperm interactions with the female reproductive tract. Cell Tissue Res. 2016;363(I):I85-I94. doi:I0.1007/s0044I-0I5-2244-2 


\section{Sistema Genito - Urinario y Endocrino}

4. Miller DJ. Regulation of Sperm Function by Oviduct Fluid and the Epithelium: Insight into the Role of Glycans. Reprod Domest Anim. 2015;50 Suppl 2:31-39. doi: I0. I I I I/rda. I 2570

5. Garner DL, Evans KM, Seidel GE. Sex-sorting sperm using flow cytometry/cell sorting. Methods Mol Biol. 20 I3;927:279-295. doi:I0.I007/978-I-62703-038-0_26

6. Chakari W, Hesselfeldt I, Caspara CU. Ugeskr Laeger. 20 I8; I80(8):V04I 70325.

7. Hosken DJ, Archer CR, House CM, Wedell N. Penis evolution across species: divergence and diversity. Nat Rev Urol. 2019;16(2):98-I06. doi:I0.1038/s4I585-0I8$0112-z$

8. Ge W, Zhu X, Xu Y, Chen Y, Wang J. Therapeutic effects of modified Devine surgery for concealed penis in children. Asian J Surg. 2019;42(I):356-36I. doi:10.1016/j.asjsur.2018.06.007

9. Zhang QI, Xia ID, Song NH. Zhonghua Nan Ke Xue. 20I8;24(I2):II26-II3I.

10. Burri A, Buchmeier J, Porst H. The Importance of Male Ejaculation for Female Sexual Satisfaction and Function [published correction appears in J Sex Med. 2019 |ul; I6(7): I I 231. I Sex Med. 20 I8; I5(I I):I600-I608. doi:I0.1016/j.jsxm.20 I8.08.0I4

II. Chen Y, Chen JH. Zhonghua Nan Ke Xue. 20I8;24(I I):963-966.

12. Auer T, De Zordo T, Horninger W, laschke W, Aigner F. Multiparametrischer Ultraschall des Hodens--ausgewählte Fälle [Multiparametric US of the Testicles-Selected Cases]. Rofo. 20 I6; I88(4):33 I-335. doi:I0.1055/s-004I-I I 0806

I3. Mil'to IV, Sukhodolo IV, Ivanova VV, Usov VY. Structure of Rat Testicles after Intravenous Injection of Nanosized Magnetite Particles. Bull Exp Biol Med. 2019;166(5):680-685. doi:I0.1007/s I05 I7-019-044 I7-z

14. Bitkin A, Bașak Ozbalci A, Aydin M, et al. Effects of varicocele on testicles: Value of strain elastography: A prospective controlled study. Andrologia. 20 I9;5 I(I):el3 I6I. doi: I0.III I/and. I3 I6I

15. Krishnaswami S, Fonnesbeck C, Penson D, McPheeters ML. Magnetic resonance imaging for locating nonpalpable undescended testicles: a meta-analysis. Pediatrics. 20I3; I3 I (6):el908-el916. doi:I0.I542/peds.2013-0073

16. Ellett ID, Rosoff IS, Prasad MM. Three testicles in one hemiscrotum: an unusual presentation of polyorchidism. BM/ Case Rep. 2015;20I5:bcr2014206033. Published 2015 Jan 6. doi:I0.II36/bcr-20I4-206033

17. Dai X, Nie G, Cao H, Xing C, Hu G, Zhang C. In vivo assessment of molybdenum and cadmium co-induced the mRNA levels of heat shock proteins, inflammatory cytokines and apoptosis in shaoxing duck (Anas platyrhyncha) testicles. Poult Sci. 20I9;98(I I):5424-543I. doi:10.3382/ps/pez328 
Sistema Genito - Urinario y Endocrino

Capítulo II

Aparato reproductor femenino

CAPITULO II 


\section{Sistema Genito - Urinario y Endocrino}

\section{APARATO REPRODUCTOR FEMENINO}

\section{Ovarios}

Los ovarios son dos estructuras del $3 \times 2 \mathrm{~cm}$ que están a ambos lados del útero, cerca de la parte distal de la trompa. Cada uno está sostenido por tres ligamentos que lo mantienen en posición y es el equivalente embriológico de los testículos. La función principal de los ovarios es la de producir las hormonas femeninas y liberar el óvulo todos los meses, durante el proceso de reproducción. Durante la vida intrauterina, los ovarios tienen alrededor de 7 millones de células capaces de producir óvulos (oogonias). Para el momento del nacimiento sólo quedan 400.000 células (oocitos primarios), que se mantienen inactivas hasta la pubertad.

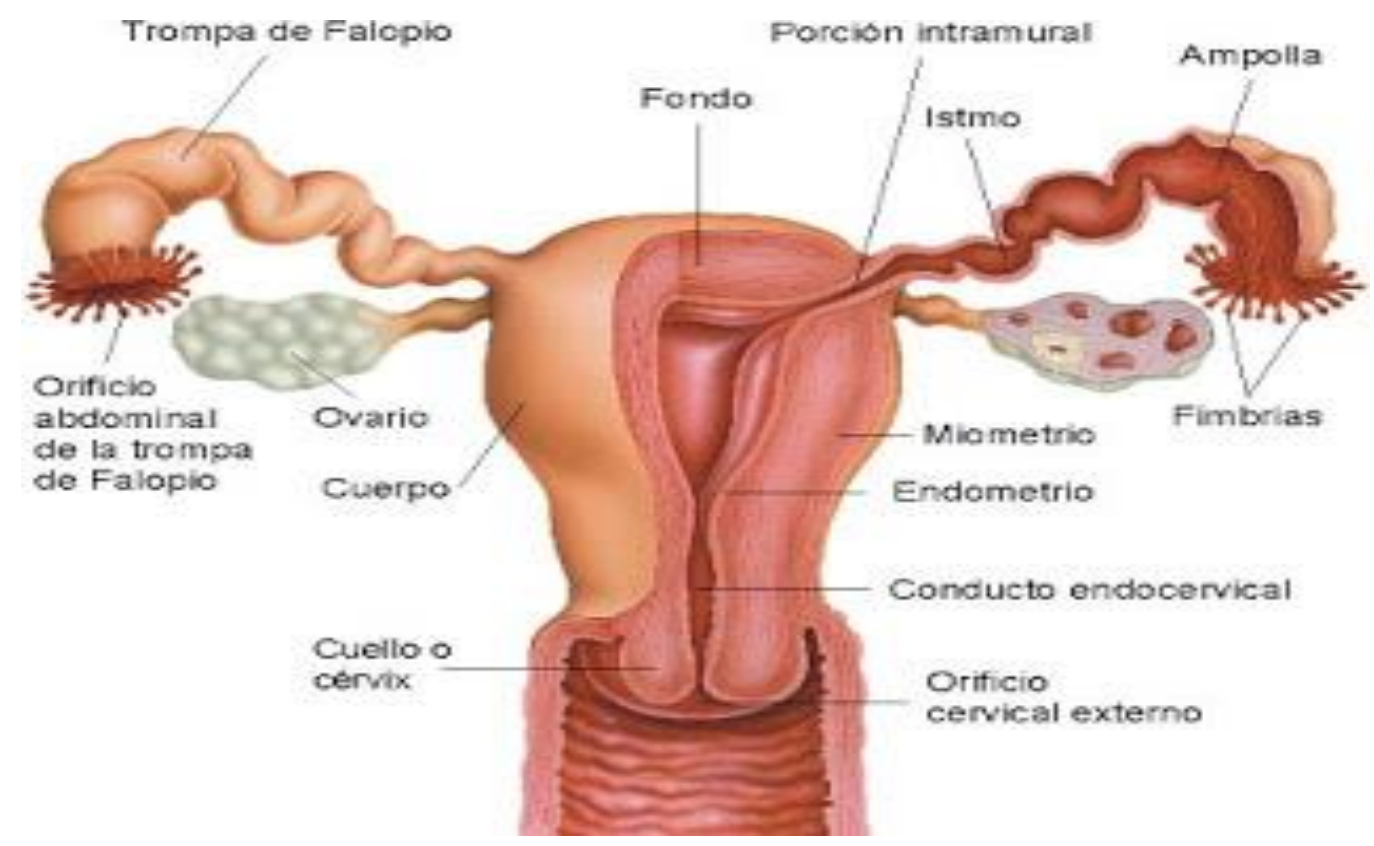

En ese momento, comienzan a ser estimuladas por las hormonas de la hipófisis, llamadas 


\section{Sistema Genito - Urinario y Endocrino}

gonadotropinas, que son: la hormona folículo estimulante $(\mathrm{FSH})$ y la hormona luteinizante (LH). Cada oocito está rodeado de una serie de estructuras celulares que nutren el oocito y que limitan la entrada de los espermatozoides anormales. El conjunto de oocito más las estructuras celulares que lo rodean es lo que se conoce con el nombre de folículo. El folículo crece luego de la regla y cerca de la fecha de ovulación se rompe para permitir la salida de óvulo. Los ovarios producen tres hormonas: estrógenos, progesterona y testosterona, cada una de las cuales tiene funciones diferentes que se analizan a continuación:

Estrógenos. El ovario produce tres estrógenos (estradiol, estrona y estriol), el más importante es el estradiol, responsable del crecimiento de los genitales internos, la maduración de los genitales externos, el depósito de grasa en sitios adecuados para resaltar la feminidad y el desarrollo de las mamas. En el proceso de reproducción, los estrógenos son responsables del crecimiento del endometrio y la producción del moco del cuello uterino, que favorece la penetración de los espermatozoides.

Progesterona. Es producida en grandes cantidades después de la ovulación por el cuerpo lúteo, también llamado cuerpo amarillo por su color característico. Esta estructura se forma después de la ruptura del folículo y liberación el óvulo. La progesterona es la responsable del mantenimiento de la segunda fase del ciclo menstrual y del embarazo. Si no ocurre la implantación del embrión, el cuerpo amarillo se atrofia y viene la regla. Si hay embarazo, continúa sus funciones hasta el tercer mes de gestación en que la placenta se encarga de la producción de progesterona.

Testosterona. Es la hormona masculina pero es también producida en menores cantidades por los ovarios. Se considera la hormona de la sexualidad y en gran parte es la responsable de la libido en la mujer. En la menopausia ocurren los siguientes cambios responsables de los cambios típicos de la postmenopausia:

Cesa la producción de estrógenos y se suspenden las reglas.

No hay producción de progesterona porque no hay ovulación.

Disminuye la producción de testosterona y ocurre una disminución de la libido.

Los ovarios adquieren un aspecto parecido a un cerebro y disminuyen 


\section{Sistema Genito - Urinario y Endocrino}

considerablemente de tamaño.

Todo esto es en gran parte responsable de los procesos degenerativos típicos de la postmenopausia.

\section{Ovogénesis y desarrollo folicular}

La gametogénesis es el proceso de formación de gametos (espermatozoides y óvulos) a nivel de las gónadas (testículos y ovarios). Este proceso es regulado por la acción de la hormona FSH.

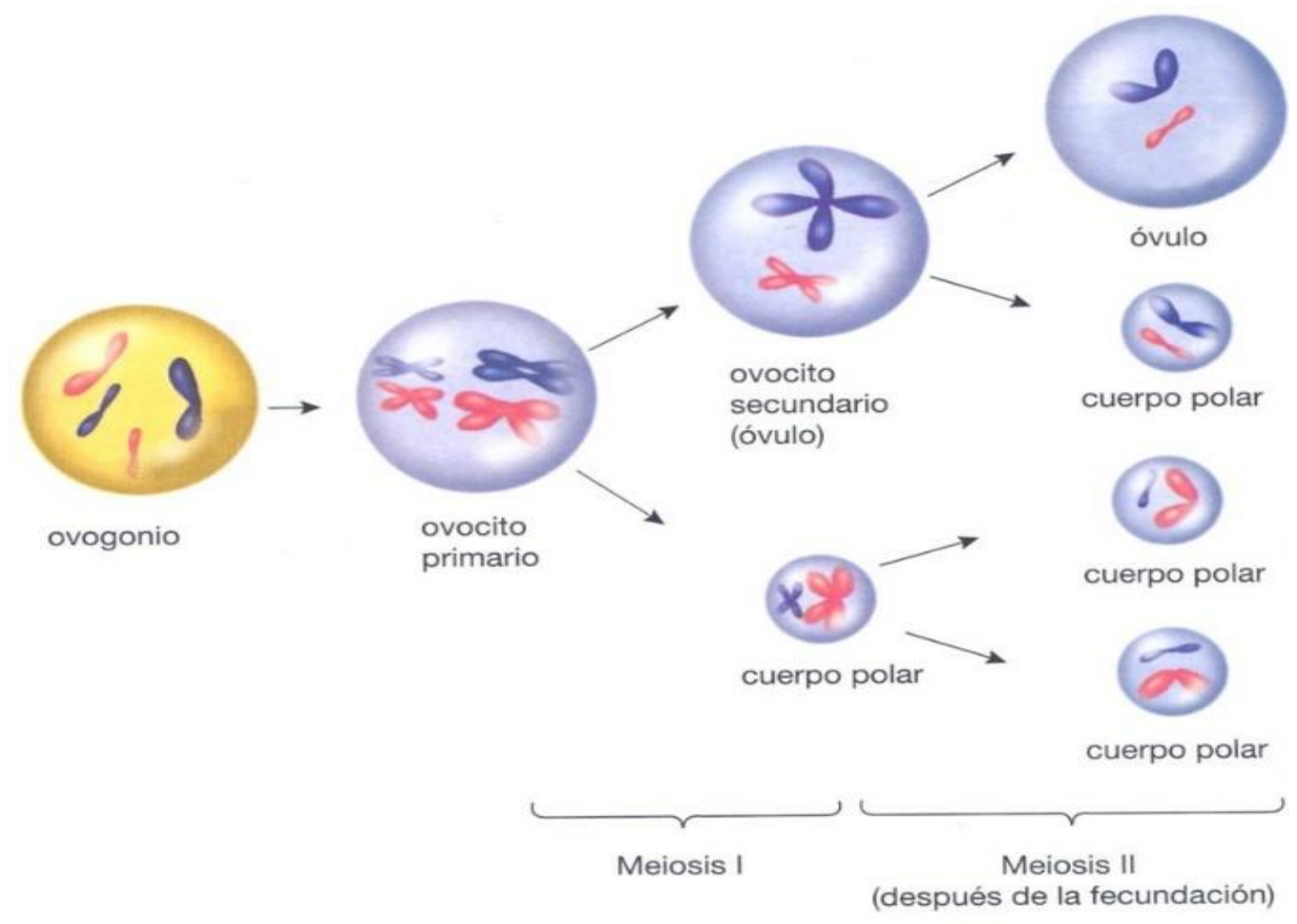

\section{Ovogénesis}

Es el proceso de formación y maduración del óvulo. La ovogénesis se lleva a cabo en la corteza ovárica. La mujer al nacer tiene, aproximadamente, 400,000 folículos primordiales, de los cuales, en la etapa fértil, sólo se llegan a desarrollar 400. En la corteza del ovario se hallan folículos en diferentes grados de desarrollo, dentro de los cuales se encuentra el ovocito. El folículo desarrolla, junto con el ovocito, siguiendo la siguiente secuencia: 


\section{Sistema Genito - Urinario y Endocrino}

-Folículo primordial

-Folículo primario

-Folículo secundario

-Folículo maduro o de D'Graff.

La progresión de la foliculogénesis, es decir el pasaje por los distintos estadios de desarrollo del folículo está basada en la capacidad que tienen las células foliculares para dividirse y diferenciarse. Los folículos primordiales continuamente abandonan la reserva para convertirse en folículos primarios. Esta transición implica ciertos cambios. Alcanza un diámetro dos a tres veces mayor al de los folículos primordiales y a medida que el ovocito aumenta de tamaño, la capa única de células foliculares aplanadas se convierte inicialmente en una capa de células cúbicas y luego cilíndricas.

Estas células gradualmente muestran mayor actividad mitótica y proliferan adoptando el aspecto de un epitelio estratificado. Como su citoplasma tiene aspecto granular, se las suele llamar también células de la granulosa. En esta fase el ovocito, con un diámetro de 50 a $80 \mu \mathrm{m}$, se halla separado de las células foliculares por una membrana transparente y homogénea, que recibe el nombre de zona pelúcida. A medida que los folículos aumentan de tamaño, van desplazándose gradualmente hacia el interior de la corteza.

\section{Diferenciación ovárica durante el desarrollo embrionario}

En el embrión del mamífero, el rudimento gonadal puede diferenciarse indistintamente en un ovario o un testículo. Durante su etapa indiferenciada, la gónada se aprecia inicialmente como un engrosamiento del epitelio celómico y una evaginación del mesénquima en el lado medial de la cresta mesonéfrica. Conforme el tejido engrosado se distingue del mesonefros, la cresta genital se forma durante las semanas 4 y 5 de la gestación en el humano y en el día 9 en el ratón. Las células del epitelio celómico en la cresta genital proliferan y migran hacia el tejido mesenquimático laxo adyacente en el reborde de la gónada indiferenciada, la cual ya es reconocible durante la semana 6 del desarrollo embrionario en el humano y el día II en el ratón.

Los conductos de Wolff aparecen en el mesonefros durante la semana 4 en el humano y 


\section{Sistema Genito - Urinario y Endocrino}

en el día 10 en el ratón, mientras que los müllerianos aparecen en la semana 6 en el desarrollo del humano y en el día II en el ratón. En etapas posteriores del desarrollo de la hembra, los primeros sufrirán una regresión debido a la falta de andrógenos, mientras que los müllerianos darán origen al oviducto, útero y la parte superior de la vagina, sin que el desarrollo del tracto reproductivo femenino sea dependiente de los estrógenos.

El número de células germinales primordiales es relativamente pequeño y éstas proliferan durante su migración, alcanzando un número final de 2500 a 5000 ovogonias en la gónada. Estas se organizan posteriormente en grupos y continúan su proliferación hasta entrar a la profase meiótica, disponiéndose en la periferia de la corteza del futuro ovario.

\section{Trompas uterinas}

Son dos trompas uterinas u oviductos, que se extienden en sentido lateral, desde el útero. Las trompas, yacen entre los pliegues de los ligamentos anchos del útero. Proveen una ruta para que los espermatozoides alcancen el óvulo y transporta los ovocitos secundarios y óvulos fertilizados, desde los ovarios hacia el útero. La porción en forma de embudo de cada trompa, llamada infundíbulo, se encuentra próxima al ovario y abierta hacia la cavidad pelviana. Termina en un penacho de proyecciones digitiformes, las fimbrias, una de las cuales se encuentra unida al borde lateral del ovario, desde el infundíbulo, la trompa uterina se extiende en dirección medial y luego hacia abajo, y se une al ángulo lateral superior del útero. La ampolla de la trompa uterina es la porción más ancha y más larga; constituye los dos tercios laterales de la trompa. El istmo de la trompa uterina es la porción más medial, corta, angosta y de paredes gruesas que se une al útero.

\section{Anatomía microscópica.}

Se componen de tres capas: la mucosa, la muscular y la serosa. La mucosa consiste en el epitelio y la lámina. El epitelio tiene células ciliadas cilíndricas simples, que funcionan como una "cinta transportadora ciliar", que ayuda al óvulo fecundado a desplazarse a lo largo de la trompa uterina hacia el útero, y células no ciliadas, que tienen microvellosidades y secretan un líquido que provee de nutrientes al óvulo. La capa muscular, está formada por un anillo interno y grueso de músculo liso circular, además de una región externa y 


\section{Sistema Genito - Urinario y Endocrino}

delgada de músculo liso longitudinal. Las contracciones peristálticas de la muscular, junto con la acción ciliar de la mucosa, ayudan al ovocito o al óvulo fecundado a desplazarse hacia el útero.

La capa externa de las trompas uterinas es una serosa. Después de la ovulación, se producen corrientes locales debido a los movimientos de las fimbrias que rodean la superficie del folículo maduro, poco antes de que se produzca la ovulación. Estas corrientes barren el ovocito secundario ovulado, desde la cavidad peritoneal hacia la trompa uterina. Un espermatozoide normalmente se encuentra con un ovocito secundario y lo fecunda en la ampolla de la trompa. La fecundación puede producirse en cualquier momento, dentro de las 24 horas posteriores a la ovulación. Unas horas después de ocurrida la fecundación, los materiales nucleares del óvulo y el espermatozoide haploides se unen. El óvulo fecundado diploide se llama ahora cigoto.

\section{Útero}

El útero forma parte del camino que siguen los espermatozoides depositados en la vagina para alcanzar las trompas uterinas. Es también el sitio de implantación del óvulo fecundado, de desarrollo para el feto durante el embarazo y el parto. Está situado entre la vejiga urinaria y el recto, el útero tiene el tamaño y la forma de una pera invertida. En las mujeres que nunca estuvieron embarazadas mide alrededor de $7,5 \mathrm{~cm}$ de largo, $5 \mathrm{~cm}$ de ancho y $2,5 \mathrm{~cm}$ de espesor. El útero es más grande en las mujeres con embarazos recientes y más pequeño cuando los niveles hormonales son bajos, como ocurre después de la menopausia.

\section{Las subdivisiones anatómicas del útero son:}

I) Una porción en forma de cúpula, por encima de las trompas uterinas, llamada fondo uterino,

2) Una porción central estrecha, el cuerpo uterino,

3) Una porción inferior angosta, el cuello o cérvix, que se abre hacia la vagina.

Entre el cuerpo del útero y el cuello, se encuentra el istmo, una región estrecha de alrededor de $\mathrm{I} \mathrm{cm}$ de largo. El interior del cuerpo uterino constituye la cavidad uterina, y 


\section{Sistema Genito - Urinario y Endocrino}

la porción interior del cuello, el conducto del cuello uterino.

El canal cervical se abre hacia la cavidad uterina por el orificio interno y a la vagina, por el orificio externo. El cuello se proyecta hacia abajo y hacia atrás y se une a la pared anterior de la vagina en un ángulo casi recto, varios ligamentos, que son extensiones del peritoneo parietal o cordones fibromusculares, mantienen al útero en posición (los dos ligamentos anchos son pliegues dobles de peritoneo que fijan el útero a cada lado de la cavidad pelviana; el par de ligamentos rectouterinos, también extensiones peritoneales, se sitúa a cada lado del recto y conecta el útero con el sacro.

Los ligamentos cardinales se ubican por debajo de las bases de los ligamentos anchos y se extienden desde la pared pelviana hasta el cuello y la vagina; los ligamentos redondos son bandas de tejido conectivo fibroso, ubicados entre las capas de los ligamentos anchos; se extienden desde un punto en el útero inmediatamente inferior a las trompas uterinas hasta una porción de los labios mayores, en los genitales externos; los ligamentos también permiten al cuerpo uterino la suficiente libertad de movimiento como para que el útero pueda quedar fuera de su posición normal.

\section{Anatomía microscópica}

El útero está compuesto por tres capas de tejido: perimetrio, miometrio y endometrio.

El perimetrio es una serosa que forma parte del peritoneo visceral. El miometrio, está formado por tres capas de fibras musculares lisas, más gruesas en el fondo y más delgadas en el cuello. La capa media, más gruesa, es circular; las capas interna y externa son longitudinales u oblicuas. Durante el parto, las contracciones coordinadas del miometrio en respuesta a la oxitocina proveniente de la neurohipófisis ayudan a expulsar al feto del útero. El endometrio se encuentra ricamente vascularizada y tiene tres componentes:

I) Una capa más interna de epitelio cilíndrico simple bordea la luz,

2) Una capa subyacente de estroma endometrial, que forma una región de lámina propia muy gruesa,

3) Las glándulas endometriales aparecen como invaginaciones del epitelio luminal y se extienden casi hasta el miometrio. 


\section{Sistema Genito - Urinario y Endocrino}

\section{Moco cervical}

Las células secretoras de la mucosa del cuello cervical producen una secreción, el moco cervical, una mezcla de agua, glucoproteínas, lípidos, enzimas y sales inorgánicas. Durante sus años reproductivos, las mujeres secretan 20-60 mL de moco cervical por día. El moco cervical es más apto para los espermatozoides durante el tiempo de ovulación o próximo a este, debido a que en ese momento es menos viscoso y más alcalino ( $\mathrm{pH} 8,5)$. Durante el resto del ciclo un moco viscoso forma un tapón cervical que impide físicamente el paso de los espermatozoides. (Derrickson).

El moco cervical suplementa las necesidades energéticas de los espermatozoides y tanto el cérvix como el moco protegen a los espermatozoides de fagocitos y del ambiente hostil de la vagina y el útero, el moco cervical también podría cumplir una función en la capacitación, una serie de cambios funcionales que atraviesan los espermatozoides en el aparato genital femenino, antes de ser capaces de fecundar el ovocito secundario. La capacitación hace que la cola del espermatozoide se agite en forma aún más vigorosa y prepara la membrana plástica de éste para fusionarse con la membrana plasmática del ovario. (Derrickson).

\section{Vagina}

La vagina (vagina=vaina) es un conducto fibroso muscular tubular de $10 \mathrm{~cm}$ de largo recubierto por una membrana mucosa, que se extiende desde el exterior del cuerpo hasta en cuello uterino (Derrickson). Es el receptáculo del pene durante las relaciones sexuales, el lugar de salida para él flujo menstrual y el canal de parto. Situada entre la vejiga urinaria y el recto, la vagina se orienta en dirección superior y posterior, en donde se une con el útero. Un fondo de saco llamado formix (arco o bóveda) o fondo del saco vaginal rodea la unión de la vagina con él cuello uterino. (Derrickson). 


\section{Sistema Genito - Urinario y Endocrino}

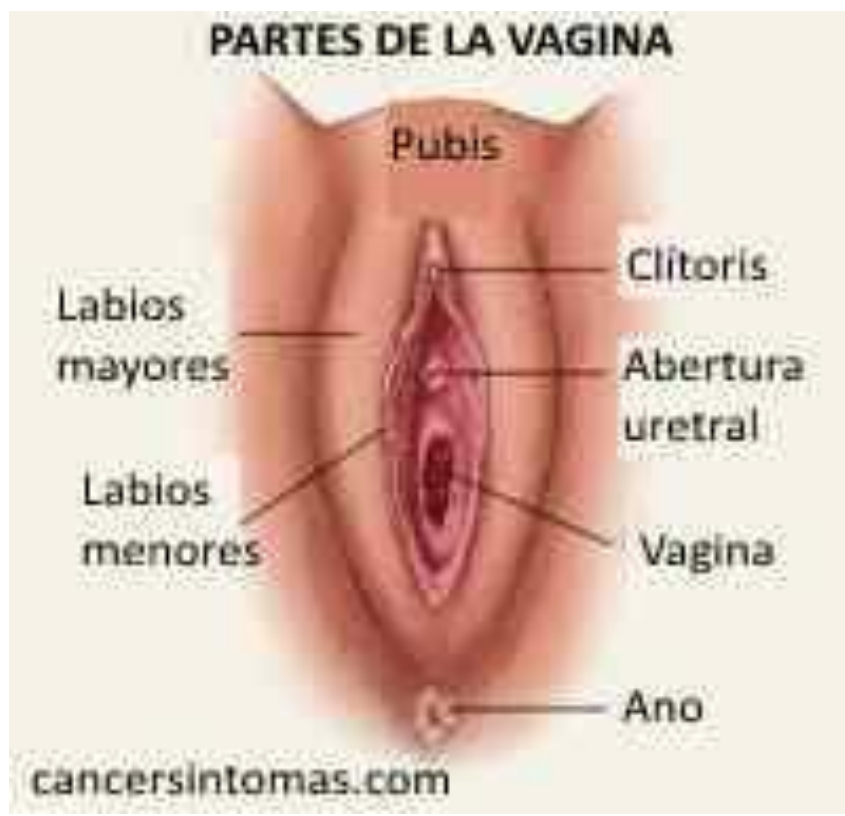

Cuando se coloca en forma adecuada un diafragma anticonceptivo, este queda ubicado en el fondo del saco vaginal cubriendo el cuello uterino. La mucosa de la vagina se encuentra en continuidad con la del útero. Desde el punto de vista histológico está formado por un epitelio (plano pavimentoso) escamoso estratificado no queratinizado y tejido conectivo laxo, que se dispone formando pliegues transversales llamados pliegues de la vagina. Las células dendríticas de la mucosa son células presentadoras de antígeno. Desafortunadamente, también participan en la transición de virus (p.j. él $\mathrm{VIH}$ o virus del SIDA) a la mujer durante las relaciones sexuales con un hombre infectado.

La mucosa vaginal contiene grandes reservas de glucógeno, que produce ácidos orgánicos al descomponerse. En ambiente ácido resultante retarda él crecimiento microbiano, pero también es nocivo para los espermatozoides, los componentes alcalinos del semen, secretados sobre todo por las vesículas seminales, eleva el $\mathrm{pH}$ del fluido en la vagina y así aumentan la viabilidad de los espermatozoides. (Derrickson).

La muscular está formada por una capa muscular externa y una capa longitudinal interna de músculo liso que puede alongarse considerablemente para adaptase al tamaño. La adventicia, la capa superficial de la vagina, está formada por tejido conectivo laxo. Esta fija 


\section{Sistema Genito - Urinario y Endocrino}

la vagina a los órganos adyacentes, como la uretra y la vejiga urinaria hacia adelante, y al recto y al canal hacia atrás del pene durante las relaciones sexuales y él tamaño del bebe durante el parto. (Derrickson).

Un delgado pliegue de membrana mucosa vascuralizada, el himen, forma un borde que rodea y cierra parcialmente él extremo inferior de apertura hacia el exterior de la vagina, él orificio vaginal. Después de su ruptura, en general luego de la primera relación sexual, solo persisten remanentes del himen. Algunas veces, el himen cubre el orificio completamente, una patología conocida como himen perforado. Puede ser necesaria una intervención quirúrgica para abrir el orificio y permitir la salida del flujo menstrual. (Derrickson)

\section{VULVA}

El termino vulva se refiere a los genitales externos de la mujer. La vulva está constituida por los siguientes componentes:

a) Anterior a los orificios de la uretra y la vagina, se encuentra el monte del pubis, una elevación de tejido adiposo cubierta por piel y vello púbico grueso que protege la sínfisis pubiana

b) Desde el monte del pubis, dos pliegues longitudinales de piel, los labios mayores, se extienden en dirección inferior y posterior. Los labios mayores están cubiertos por vello púbico y contiene abundante tejido adiposo, glándulas sebáceas y glándulas sudoríparas apocrinas, son homólogos del escroto en el hombre.

El clítoris es una pequeña masa cilíndrica compuesta por dos cuerpos de tejido eréctil, los cuerpos cavernosos, y numerosos nervios y vasos sanguíneos. El clítoris se localiza en la unión anterior de los labios menores. El clítoris es homólogo del glande en los hombres. La región entre ambos labios menores es el vestíbulo de la vagina. Dentro de él se encuentra el himen, el orificio vaginal, el orificio uretral externo y los orificios de los conductos de varias glándulas. El vestíbulo es homólogo de la uretra membranosa de los hombres. El bulbo del vestíbulo está formado por dos masas alargadas de tejido eréctil y están ubicado por debajo de los labios a cada lado del orificio vaginal. El bulbo del 


\section{Sistema Genito - Urinario y Endocrino}

vestíbulo es homólogo del cuerpo esponjoso y el bulbo del pene en los hombres. (Derrickson)

\section{Periné}

El periné, el perineo (perineum) o suelo pélvico es la región anatómica correspondiente al suelo de la pelvis, conformada por el conjunto de partes blandas que cierran hacia abajo el fondo de la pelvis menor (pelvis menor), la excavación pélvica (cavum pelvis).

La inspección de la zona tiene importancia médico-sanitaria para el diagnóstico de enfermedades de transmisión sexual $y$, asimismo, tiene relevancia médico-legal por la posibilidad de recolectar muestras e información, en un contexto médico-forense, ante casos de violación o abuso sexual.

\section{Perineo femenino}

Los músculos y las aponeurosis del perineo femenino tienen la misma disposición general que el perineo masculino. Las principales diferencias se deben a la separación del aparato genital (vagina) del urinario (uretra) al momento de traspasar la región perineal anterior (diafragma urogenital).

Perineo femenino

Plano superficial

Músculo esfínter externo del ano

Músculo transverso superficial

Músculo isquiocavernoso.

\section{Glándulas mamarias}

Cada mama es una proyección semiesférica de tamaño variable, situada por delante de los músculos pectoral mayor y serrato anterior y unido a ellos por una capa de fascia profunda compuesta por tejido conectivo denso irregular. En cada mama se observa una proyección pigmentada, el pezón, que tiene una serie de aberturas de conductos, llamados conductos galactóforos, por donde sale la leche. El área de piel pigmentada circular que rodea el pezón se llama aréola (pequeño espacio); su apariencia rugosa se debe a que tiene glándulas sebáceas modificadas. Las hebras de tejido conectivo, los ligamentos 


\section{Sistema Genito - Urinario y Endocrino}

suspensorios de la mama (ligamentos de Cooper) se extienden entre la piel y la fascia profunda y sostienen la mama.

Estos ligamentos se aflojan con la edad o con la tensión excesiva que puede producirse, por ejemplo, al correr por tiempo prolongado o realizar ejercicios aeróbicos de alto impacto. El uso de un sujetador con buen sostén puede retrasar este proceso y ayudar a mantener la tensión de los ligamentos de Cooper. Dentro de cada mama, encontramos una glándula mamaria, una glándula sudorípara modificada que produce leche. Cada glándula está formada por 15 o 20 lóbulos o compartimentos, separados por una cantidad variable de tejido adiposo.

En cada lóbulo existen varios compartimentos más pequeños denominados lobulillos, compuestos por racimos de células secretoras de leche, los alvéolos, rodeados de tejido conectivo. La contracción de las células mioepiteliales que rodean los alvéolos impulsa la leche hacia los pezones. Cuando comienza la producción de leche, ésta pasa de los alvéolos a una serie de túbulos secundarios y luego, a los conductos mamarios. Cerca del pezón, los conductos mamarios se expanden para formar los senos galactóforos (gálaktos, leche; y phorós), donde puede almacenarse parte de la leche, antes de ser drenada a un conducto galactóforo. Típicamente, cada conducto galactóforo transporta la leche desde uno de los lóbulos hacia el exterior

Las funciones de la glándula mamaria son: la síntesis, secreción y eyección de leche; estas funciones, conocidas como lactación, se asocian con el embarazo y el parto. La producción de leche es estimulada, en gran parte, por la hormona prolactina, secretada por la adenohipófisis, con ayuda de la progesterona y los estrógenos. La eyección de la leche es estimulada por la oxitocina, liberada por la neurohipófisis en respuesta a la succión del pezón de la madre por parte del lactante (amamantamiento). 


\section{Sistema Genito - Urinario y Endocrino}

\section{BIBLIOGRAFÍA SUGERIDA}

I. Zhu RY, Wong YC, Yong EL. Sonographic evaluation of polycystic ovaries. Best Pract Res Clin Obstet Gynaecol. 2016;37:25-37. doi:I0. I016/j.bpobgyn.2016.02.005

2. Díaz-Hernández V, Caldelas I, Montaño LM, Merchant-Larios H. Morphological rearrangement of the cortical region, in aging ovaries. Histol Histopathol. 2019;34(7):775-789. doi: I0.14670/HH-18-078

3. Urbisz AZ, Chajec Ł, Brąszewska-Zalewska A, Kubrakiewicz I, Świątek P. Ovaries of the white worm (Enchytraeus albidus, Annelida, Clitellata) are composed of 16 celled meroistic germ-line cysts. Dev Biol. 2017;426(I):28-42. doi:10.1016/i.ydbio.2017.04.009

4. Togashi K. MR imaging of the ovaries: normal appearance and benign disease. Radiol Clin North Am. 2003;4 I (4):799-8I I. doi:I0.10 I6/s0033-8389(03)0004 I I

5. Gethöffer F, Pfarrer C, Siebert U. Histology confirms that macroscopic evaluation of ovaries is a valid method for the assessment of the reproductive status in wild boar. Theriogenology. 20 I8; I 3:192-196. doi:I0.1016/j.theriogenology.2018.02.019

6. Hikabe O, Hamazaki N, Nagamatsu G, et al. Reconstitution in vitro of the entire cycle of the mouse female germ line. Nature. 2016;539(7628):299-303. doi:10.1038/nature20104

7. Macias H, Hinck L. Mammary gland development. Wiley Interdiscip Rev Dev Biol. 20I2; I (4):533-557. doi:I0.1002/wdev.35

8. Inman IL, Robertson C, Mott ID, Bissell MI. Mammary gland development: cell fate specification, stem cells and the microenvironment. Development. 2015;| 42(6): I028-I042. doi:10.1242/dev.087643

9. Hassiotou F, Geddes D. Anatomy of the human mammary gland: Current status of knowledge. Clin Anat. 2013;26(I):29-48. doi:I0.1002/ca.22I65

10. Tharmapalan P, Mahendralingam M, Berman HK, Khokha R. Mammary stem cells and progenitors: targeting the roots of breast cancer for prevention. EMBO J. 2019;38(|4):el00852. doi:I0.15252/embj.20I8I00852 
Sistema Genito - Urinario y Endocrino

\section{Capítulo III}

Diagnóstico diferencial y definitivo de las patologías del aparato reproductor masculino y femenino 


\section{Sistema Genito - Urinario y Endocrino}

\section{CAPÍTULO III}

\section{PATOLOGIAS DEL APARATO REPRODUCTOR MASCULINO}

\section{Criptorquidia}

Al principio de la vida fetal los testículos en la cavidad abdominal, normalmente, descienden al escroto unos 2 meses antes del nacimiento. En ocasiones el niño nace con los testículos sin descender, un cuadro denominado criptorquidia que se observa fácilmente por palpación del escroto al parto. La palabra criptorquidia procede de la palabra griega kryptikos, escondido y orchis, testículo.

La falta de descenso testicular puede deberse a desequilibrios hormonales en el feto en desarrollo o a un defecto u obstrucción físico independientemente de su causa. En el lactante criptorquidico, los testículos permanecen escondidos en la cavidad abdominal. Como la temperatura más alta en el interior de la cavidad del cuerpo inhibe la espermatogenia, deben tomarse medidas para hacer descender los testículos en el escroto y evitar la esterilidad permanente. El tratamiento precoz de este cuadro se realiza mediante la cirugía o mediante la inyección de testosterona, los cuales estimulan al descenso de los testículos y pueden dar lugar al desarrollo testicular y sexual normal.

\section{Eyaculación precoz}

Existen diferentes teorías fisiopatológicas que tratan de explicar este fenómeno. Las más tradicionales hablan de un origen psicosexológico, con gran componente de ansiedad. Otros autores hablan de una hipersensibilidad del pene, que daría lugar a una eyaculación ante mínimos estímulos en el glande. Las tendencias más recientes apoyan la teoría de que la eyaculación precoz se debe a un desequilibrio o deficiente regulación en la cantidad de serotonina disponible en la sinapsis, al número de receptores presinápticos y postsinápticos que la expresan o a la sensibilidad de éstos. 


\section{Sistema Genito - Urinario y Endocrino}

\section{Alteraciones Prostáticas}

Debido a que la próstata rodea parte de la uretra, cualquier agrandamiento o tumor puede obstruir el flujo urinario. Las infecciones agudas y crónicas de la próstata son comunes después de la pubertad, a menudo asociadas con inflamación de la uretra. Los síntomas pueden incluir fiebre, escalofríos, aumento de la frecuencia urinaria, micción frecuente durante la noche, dificultad para orinar, ardor o dolor al orinar, dolor en la zona lumbar, dolores articulares y musculares, sangre en la orina o eyaculación dolorosa, sin embargo, puede no haber síntomas.

La mayoría de los casos se producen por infección bacteriana y se tratan con antibióticos. En la prostatitis aguda, la próstata se inflama y es dolorosa a la palpación. La prostatitis crónica es una de las infecciones más comunes en el hombre de edad mediana y en los mayores. En el examen, la próstata se palpa agrandada, blanda y con su superficie irregular, causando dolor.

\section{Cáncer de próstata}

Uno de los tipos de cáncer más habituales en los hombres, el cáncer de próstata, aparece cuando se forma un tumor maligno en la parte externa de esta glándula. Es frecuente en hombres ya mayores del mundo desarrollado, entre los que constituyen una de las causas principales de muerte. A medida que el cáncer se desarrolla, la próstata aumenta de tamaño, lo que dificulta el paso de la orina. En algunos casos, el tumor es capaz de llegar a bloquearlo totalmente. El cáncer de próstata se desarrolla muy lentamente, haciendo necesario exámenes periódicos de la glándula para detectar la enfermedad de forma precoz. Sin embargo, en algunas ocasiones puede que no haya ninguna sintomatología hasta que el cáncer se haya extendido a otra parte del cuerpo, normalmente los huesos. Cuando esto sucede, el cáncer es muy difícil de curar. 


\section{Sistema Genito - Urinario y Endocrino}

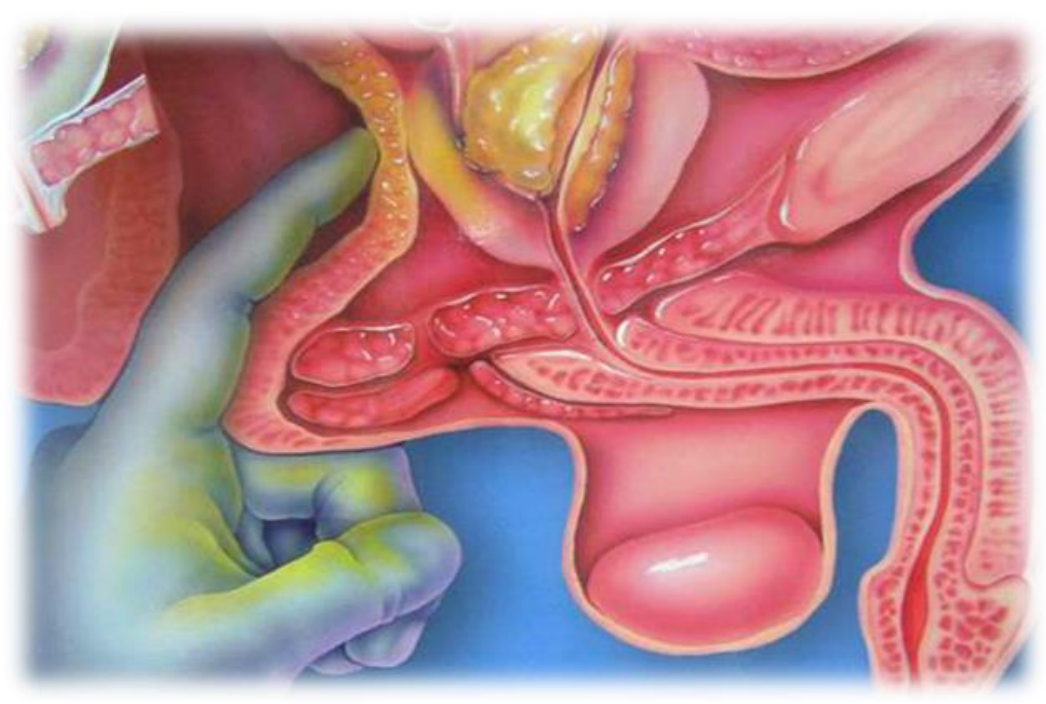

\section{Cáncer de próstata}

\section{Diagnóstico diferencial}

Prostatitis aguda: La infección bacteriana causa disuria, dolor y a menudo fiebre. La próstata es dolorosa y está agrandada, pero no es dura. El masaje prostático para la obtención de líquido está contraindicado en esta situación aguda, por lo que este diagnóstico se confirmará con un cultivo de orina positivo para el agente causal.

Prostatitis crónica granulomatosa: Causada por infección bacteriana, tuberculosa, fúngica o por protozoos. Puede dar lugar a una masa clínicamente indistinguible del cáncer. Es necesaria una biopsia para realizar el diagnóstico.

Hiperplasia benigna de próstata: Se encuentra en varones de 30 años de edad o más y en el $80 \%$ de los hombres de 80 años. Los síntomas de obstrucción urinaria son frecuentes. Los nódulos pálpales son indistinguibles de los cancerosos y precisan biopsia.

Otras enfermedades: Muy rara vez, los cálculos, la amiloidosis, los adenomas benignos o el infarto de un nódulo hiperplásico causan obstrucción o producen una masa que parece un cáncer. 


\section{Sistema Genito - Urinario y Endocrino}

\section{Diagnóstico definitivo}

La próstata es una glándula que se encuentra debajo de la vejiga de los hombres y produce el líquido para el semen. El cáncer de próstata es común en hombres de edad avanzada. Este tipo de cáncer es raro en hombres menores de 40 años. Los factores de riesgo de desarrollarlo incluyen: tener más de 65 años. Los síntomas del cáncer de próstata pueden incluir:

I. Problemas para orinar, como dolor, dificultad para iniciar o detener el flujo de orina o goteo

2. Dolor en la parte baja de la espalda

3. Dolor al eyacular.

Para diagnosticar el cáncer de próstata, se podría hacer un tacto rectal para buscar algún bulto o cualquier cosa fuera de lo normal. También podría pedir realizar un análisis de sangre de antígeno prostático específico (PSA, por sus siglas en inglés). Estos análisis también se realizan en los exámenes de detección de cáncer de próstata, los cuales intentan detectar el cáncer antes de que usted tenga síntomas. Si los resultados son anormales, usted puede necesitar otros exámenes como una ecografía, una resonancia magnética o una biopsia.

\section{Cáncer testicular}

Es una forma relativamente rara de cáncer que se suele desarrollar en hombres jóvenes de edades comprendidas entre 18 y 40 años, siendo el primer síntoma un bulto duro, habitualmente indoloro, en un testículo. También acostumbra a aparecer líquido alrededor del testículo (hidrocele) o dolor e inflamación. Este tipo de cáncer puede extenderse rápidamente a otras zonas del cuerpo, haciendo difícil el tratamiento a menos que se detecte en una etapa muy inicial. 


\section{Sistema Genito - Urinario y Endocrino}

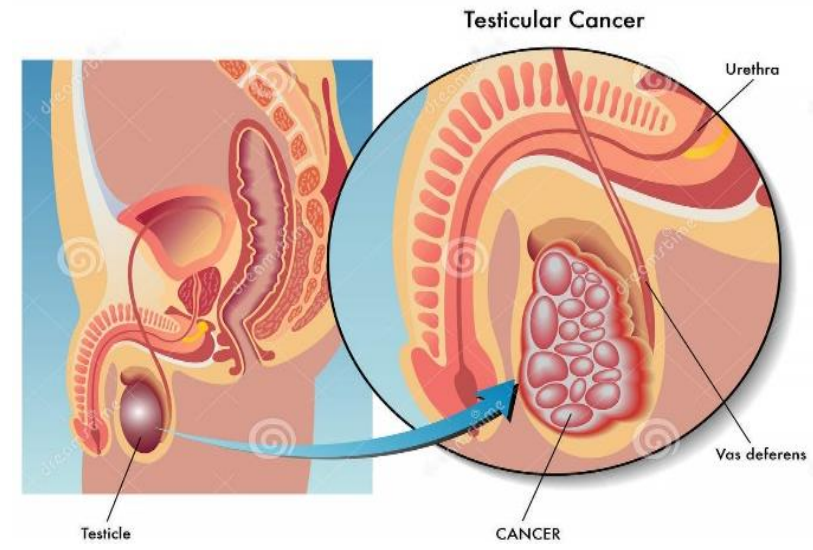

\section{Cáncer testicular}

\section{Diagnóstico diferencial}

Podemos encontrar similitud con ciertas enfermedades que son:

I. Epididimitis

2. Orco epididimitis tuberculosa

3. Hidrocele

4. Espermatocele

5. Neoplasias testiculares benignas

6. Tumores del epidídimo

7. Orquitis

8. Traumatismo testicular.

\section{Diagnóstico definitivo}

El cáncer de testículos afecta principalmente a hombres jóvenes entre los 20 y 39 años. También es más común en hombres que:

I. Tuvieron un desarrollo testicular anormal

2. Tuvieron un testículo no descendido

3. Tienen antecedentes familiares de cancer.

Los síntomas incluyen dolor, inflamación o nódulos en los testículos o la región inguinal. Los médicos utilizan exámenes físicos, de laboratorio, de imagen y una biopsia para diagnosticarlo. La mayoría de los casos son tratables, especialmente cuando se detectan 


\section{Sistema Genito - Urinario y Endocrino}

con anticipación. Las opciones de tratamiento incluyen cirugía, radiación y quimioterapia. Los tratamientos también pueden causar infertilidad. Si desea tener hijos más adelante, deberá tomar en consideración acudir a un banco de esperma antes del tratamiento.

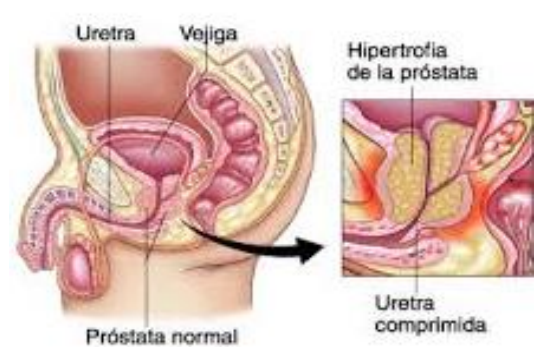

\section{Dilatación de la próstata}

En los hombres de edad avanzada es frecuente encontrar próstata dilatada. La zona interna aumenta de tamaño, comprimiendo la uretra debido a la dilatación del flujo al orinar. El estrechamiento de la uretra da lugar a un flujo de orina deficiente y a la micción frecuente durante el día y la noche. La obstrucción de salida de la orina hace que ésta se acumule en la vejiga y aumente la probabilidad de que aparezcan infecciones urinarias, haciendo que a veces se distienda la vejiga y el abdomen. En algunos casos, el paciente solo puede dejar pasar unas gotas de orina, experimentar agudos dolores abdominales y sufrir incontinencia.

\section{Torsión testicular}

Una anomalía menor en el interior del escroto permite que

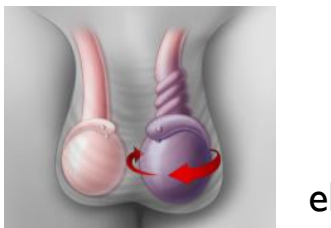
testículo retuerza el cordón testicular. Este cuadro grave es frecuente en la pubertad, porque los testículos tienen mucha movilidad en el interior del escroto. Si no se trata de inmediato, puede provocar daños permanentes en la producción de espermatozoides e 


\section{Sistema Genito - Urinario y Endocrino}

infertilidad. Los síntomas incluyen dolor agudo en el testículo y enrojecimiento en la bolsa escrotal.

\section{Epididimitis}

Es la hinchazón (inflamación) del epidídimo, del conducto que conecta el testículo con los vasos deferentes. Generalmente, es causada por la diseminación de una infección bacteriana. La infección a menudo comienza en la uretra, la próstata o la vejiga.

\section{Diagnóstico diferencial}

La torsión testicular es una afección que implica una reducción del suministro de sangre a los testículos que se asocia con síntomas similares a la epididimitis. Es importante hacer un diagnóstico diferencial, ya que la torsión testicular requiere atención médica inmediata con un procedimiento quirúrgico. Otras afecciones con síntomas que pueden confundirse con epididimitis incluyen:

I. Hidrocele

2. Tumores testiculares no seminomatosos

3. Orchitis

4. Espermatocele

5. Seminoma testicular.

\section{Diagnóstico definitivo}

Un examen físico mostrará una protuberancia roja y sensible en el lado afectado del escroto. Se puede presentar sensibilidad en una pequeña área del testículo donde está adherido el epidídimo. Se puede presentar un área grande de inflamación alrededor de la protuberancia. Se puede presentar inflamación de los ganglios linfáticos en la zona de la ingle. También puede haber un flujo o secreción del pene. Un tacto rectal puede mostrar sensibilidad o aumento del tamaño de la próstata. Se pueden realizar estos exámenes:

I. Conteo sanguíneo completo (CSC)

2. Ultrasonido Doppler

3. Gammagrafía testicular (medicina nuclear) 


\section{Sistema Genito - Urinario y Endocrino}

4. Un urocultivo y análisis de orina (se pueden necesitar varias muestras que incluyen: orina del chorro inicial, orina de la mitad del chorro y orina después de un masaje de próstata)

5. Exámenes para detectar clamidia y gonorre

\section{Fimosis}

Anomalía localizada en el pene, la cual se debe a que el prepucio y la piel que cubre y protege el glande es demasiado estrecho y no se retrae, ni de forma espontánea ni manual, impidiendo así dejar el glande al descubierto. Esta anomalía se corrige generalmente con cirugía

\section{Diagnóstico diferencial}

I. Fimosis neonatal, es siempre fisiológica

2. Parafimosis, es estrechez o anillo prepucial por detrás del glande que impide la retracción normal del prepucio.

\section{Diagnóstico definitivo}

El diagnóstico de fimosis es evidente a simple vista y se confirma por la incapacidad del examinador de retraer el prepucio.

\section{Aparato reproductor masculino. Valores de laboratorio}

Los órganos que componen el aparato reproductor masculino son los testículos y un sistema de conductos (que incluye el epidídimo, conductos deferentes, conductos eyaculadores, uretra); glándulas sexuales accesorias (vesícula seminal, próstata, y las glándulas bulbouetrales) y varias estructuras de sostén como el escroto y el pene. Los testículos (gónadas masculinas) producen espermatozoide y secretan hormonas. El sistema de conductos transporta y almacena al espermatozoide. Entre las pruebas de laboratorio una de las más importantes es sobre la fertilidad masculina:

\section{Pruebas en fertilidad masculina}

En nuestra sociedad cada día es mayor la preocupación de mujeres y hombres por los problemas que surgen a la hora de concebir hijos. Fisiológicamente, son fundamentales los factores hormonales, es decir, la capacidad que tiene nuestro organismo de generar 


\section{Sistema Genito - Urinario y Endocrino}

ciertas moléculas (hormonas) que tienen un papel básico en nuestra capacidad reproductiva.

\section{Hormonas implicadas en la fertilidad masculina}

Las causas de la infertilidad pueden ser múltiples y de origen variado; por lo que su diagnóstico puede ser complicado. Muchos de los problemas tienen un origen hormonal y se traducen en una mala formación o funcionamiento de los espermatozoides, que puede llegar a causar infertilidad en el hombre. Por tanto, un análisis hormonal resulta básico para el estudio de la fertilidad masculina. Debe incluir la valoración de las siguientes hormonas:

Hormona Folículo Estimulante (FSH). En los hombres esta hormona favorece la producción y maduración del esperma, entre otras funciones. Después de la pubertad y a lo largo de la vida del hombre adulto, el nivel de FSH se mantiene en unos valores relativamente constantes. Por ello, la medición de la FSH puede relacionarse con la producción de un bajo número de espermatozoides, que puede desencadenar problemas de fertilidad.

Hormona Luteinizante (LH). Su acción está relacionada con la hormona anterior y entre sus funciones destaca estimular la secreción de testosterona en los testículos.

Testosterona (libre y total). Es la principal hormona sexual masculina (también conocidas como andrógenos) y es necesaria para el desarrollo normal de los espermatozoides. Además, tiene un papel clave en el desarrollo de los órganos del aparato reproductor masculino y de los caracteres sexuales secundarios (aumento del tejido muscular y óseo, crecimiento de vello corporal, etc.). Esta hormona se puede encontrar de dos maneras en nuestro organismo: de forma libre circulando en la sangre; o unida a globulinas fijadoras de hormonas sexuales (SHGB), que es la forma en la que se transporta a través de la sangre a los distintos tejidos donde va a tener función biológica. La suma de ambas se conoce como testosterona total. Es importante medir ambos niveles (libre y total) debido a las diferencias funcionales entre una y otra, ya que los efectos fisiológicos de esta hormona son mayoritariamente dependientes de los niveles de testosterona libre 


\section{Sistema Genito - Urinario y Endocrino}

circulante.

Dihidrotestosterona (DHT): Es también una hormona androgénica, que proviene del metabolismo de la testosterona. En los hombres, aproximadamente el $5 \%$ de la testosterona es convertida en dihidrotestosterona y tiene un papel fundamental en el desarrollo de caracteres sexuales masculinos desde la formación del embrión. Su déficit está relacionado con el síndrome de pseudohermafroditismo en el varón; además, también es uno de los factores principales de la aparición de la alopecia androgénica (calvicie).

Prolactina: Es una hormona segregada por la hipófisis con funciones biológicas importantes en la mujer (entre otras, estimula la lactancia en las glándulas mamarias). También afecta a algunas funciones de las diferentes partes del aparato reproductor masculino (próstata, vesículas seminales y testículos). En hombres, se utiliza para realizar un seguimiento en el caso de concentraciones bajas de testosterona.

\section{Pruebas para el estudio de la fertilidad masculina}

En Laboratorio Finca España tenemos a disposición de nuestros pacientes las siguientes pruebas para el estudio de la fertilidad masculina:

\section{Espermiograma o seminograma}

Esta prueba de fertilidad masculina consiste en el estudio de una muestra de semen por observación directa al microscopio, para analizar la presencia y el estado de los espermatozoides. Entre otros parámetros, se tiene en cuenta el volumen de la muestra, viscosidad y $\mathrm{pH}$ de los espermatozoides, y se estudian características como su morfología física, su movilidad y la presencia de anomalías.

Para la realización de esta prueba hay que seguir una serie de pautas. Además, se trata de una prueba que requiere cita previa, así que si necesitas realizarla, te recomendamos contactar con el personal de laboratorio por teléfono o a través de nuestro correo electrónico, o indicárnoslo en el formulario de cita. El plazo de entrega del resultado de esta prueba es de 24 horas.

\section{Cultivo de semen o espermocultivo}

Algunas infecciones de transmisión sexual, además de ser un problema de salud para la 


\section{Sistema Genito - Urinario y Endocrino}

persona que la padece y su pareja, pueden estar asociadas a problemas de fertilidad. El cultivo de semen es una prueba de detección de algunas de estas enfermedades, en concreto las que son producidas por hongos o bacterias. Esta prueba se realiza en conjunto con un cultivo de orina, para descartar infecciones que afecten a cualquier parte tanto del aparato reproductor masculino como del sistema urinario.

Algunas de las enfermedades que pueden desencadenar las infecciones de orina y semen en hombres son la orquitis, epididimitis, prostatitis y vesiculitis seminal. Según la zona del tracto reproductor masculino afectada, estas infecciones pueden tener distintas consecuencias, entre otras:

a) Complicaciones en la formación de los espermatozoides

b) Oclusión de las vías seminales

c) Dificultar la movilidad de los espermatozoides

d) Alteración de la información genética, por fragmentación del ADN espermático.

Si se detecta una infección urinaria o seminal en su fase inicial, su especialista recurrirá a un tratamiento antibiótico para su eliminación. En el caso de infecciones graves y no tratadas puede ser necesaria una intervención quirúrgica, y sólo en procesos agudos en los que no se ha conseguido curar la infección a tiempo, se pueden producir infertilidad permanente.

\section{Otras pruebas realizadas en los estudios de fertilidad}

Los estudios de fertilidad también incluyen pruebas de enfermedades de transmisión sexual, como $\mathrm{VIH}$ y hepatitis, ya que es necesario descartarlas a la hora de decidir concebir un/a hijo/a.

\section{Pruebas ETS}

Pruebas para detectar ETS enfermedades de transmisión sexual compuesto por serología y cultivo de exudado uretral o vaginal $(\mathrm{VIH}$, Hepatitis B, Sífilis, Gonorrea, Ureaplasma, Clamideas y Tricomonas). Las pruebas de ETS son rápidas, simples y generalmente, no duelen. No hay una sola prueba para todas las enfermedades de transmisión sexual: cada ETS tiene su propia prueba. Tu médico puede ayudarte a determinar qué pruebas son las 


\section{Sistema Genito - Urinario y Endocrino}

que necesitas. Las pruebas para detectar ETS incluyen:

a) Análisis de orina, para lo cual basta con orinar en un recipiente.

b) Hisopado bucal, que consiste en un raspado en la parte interna de la mejilla con un hisopo blando para hacer la prueba de VIH.

c) Análisis de sangre, para lo cual el médico o el enfermero te sacarán sangre del brazo o te harán una rápida punción en un dedo.

d) Reconocimiento físico, en el que tu médico o enfermero te examinará el área genital para observar si tienes verrugas, llagas, erupciones, irritación o secreciones.

e) Examen de llagas, para lo cual tu médico o enfermero tomarán una muestra del líquido de las llagas o las ampollas con un hisopo.

f) Uso de un hisopo para tomar con cuidado muestras de secreciones o células del pene, la vagina, la uretra, el cuello uterino, el ano o la garganta.

g) Puedes hacerte pruebas de ETS independientemente de que tengas síntomas o no.

h) Algunas ETS se parecen y se manifiestan de modo similar, de modo que quizá te hagan pruebas para algunas otras infecciones.

\section{Testículos}

\section{Testosterona}

Este examen mide la cantidad de la hormona masculina testosterona en la sangre. Tanto los hombres como las mujeres producen esta hormona. Mucha de esta testosterona va unida a una proteína llamada globulina fijadora de hormonas sexuales (SHBG, por sus siglas en inglés). Otro examen de sangre puede medir la testosterona "libre". Sin embargo, este tipo de examen a menudo no es muy preciso.

\section{Razones por las que se realiza el examen}

Este examen se puede llevar a cabo si se tiene síntomas de producción anormal de la hormona masculina (andrógenos). En los hombres, los testículos producen la mayor parte de la testosterona en el cuerpo. Los niveles casi siempre se analizan para evaluar signos de testosterona anormal:

a) Pubertad precoz o tardía (en niños) 


\section{Sistema Genito - Urinario y Endocrino}

b) Impotencia, disfunción eréctil, bajo nivel de interés sexual, esterilidad, adelgazamiento de los huesos (en hombres)

c) Las glándulas suprarrenales también pueden producir demasiada cantidad de otros andrógenos que se convierten en testosterona. Los niveles casi siempre se analizan para evaluar signos de niveles más altos de testosterona, como:

-Acné, piel grasosa

-Cambio en la voz

-Disminución del tamaño de las mamas

-Crecimiento de vello en exceso (vello oscuro y grueso en la zona del bigote, la barba, las patillas, el pecho, las nalgas y la parte interna de los muslos)

-Aumento del tamaño del clítoris

-Ausencia o irregularidad en los periodos menstruales

-Calvicie de patrón masculino o adelgazamiento del cabello.

\section{Resultados normales}

Las mediciones normales para estos exámenes:

I. Hombres: $300-\mathrm{I}, 000 \mathrm{ng} / \mathrm{dL}$ o $10.41-34.70 \mathrm{nmol} / \mathrm{L}$

2. Mujeres: $15-70 \mathrm{ng} / \mathrm{dL}$ o $0.52-2.43 \mathrm{nmol} / \mathrm{L}$

\section{Significado de los resultados anormales}

Ciertas afecciones médicas, medicinas o lesiones pueden llevar a un nivel de testosterona bajo. El nivel de testosterona también desciende naturalmente con la edad. Un nivel bajo de testosterona puede afectar el deseo sexual, el estado de ánimo, y el cuerpo de los hombres. El aumento en los niveles de testosterona puede deberse a:
a) Enfermedad crónica
b) Hipófisis que no produce cantidades normales de algunas de sus hormonas
c) Problemas en las zonas del cerebro que controlan las hormonas
d) Tiroides hipoactiva
e) Retraso en la pubertad
f) Enfermedades de los testículos (traumatismo, infección, inmunitaria)
g) Tumor benigno de las células de la hipófisis que producen demasiada hormona 


\section{Sistema Genito - Urinario y Endocrino}

prolactina

h) Demasiada grasa corporal (obesidad)

i) La disminución en la testosterona puede deberse a:

j) Resistencia a la acción de las hormonas masculinas (resistencia a los andrógenos)

k) Tumor de los ovarios

I) Cáncer testicular

m) Hiperplasia suprarrenal congénita

n) Tomar medicamentos o drogas que incrementen los niveles de testosterona.

\section{Androstenediona sérica}

La androstenediona es también una hormona androgénica, que proviene del metabolismo de la testosterona. En los hombres, aproximadamente el $5 \%$ de la testosterona es convertida en dihidrotestosterona y tiene un papel fundamental en el desarrollo de caracteres sexuales masculinos desde la formación del embrión. Su déficit está relacionado con el síndrome de pseudohermafroditismo en el varón; además, también es uno de los factores principales de la aparición de la alopecia androgénica (calvicie).

\section{Resultados normales}

Hombres: 23 - $89 \mathrm{ng} / \mathrm{dL} \quad(0,3 \mathrm{I}-3, \mathrm{I} \mathrm{nmol} / \mathrm{L})$

\section{Próstata}

\section{PSA Específico}

Razones para un examen del antígeno prostático específico:

I. El examen se puede hacer para detectar cáncer de próstata.

2. También se utiliza para vigilar a pacientes después del tratamiento para cáncer de próstata para ver si el cáncer ha reaparecido.

3. La medición del nivel de PSA puede aumentar la probabilidad de encontrar cáncer de próstata en una etapa temprana. Sin embargo, el valor de la prueba de detección del PSA para el cáncer de próstata es polémico. No hay una sola respuesta que se ajuste a todos los hombres.

4. Si usted opta por hacerse las pruebas, el PSA se realiza con mayor frecuencia 


\section{Sistema Genito - Urinario y Endocrino}

todos los años para examinar hombres:

5. De 55 a 69 años, si no se presenta ningún factor de riesgo.

6. Comenzando alrededor de la edad de 40 a 45 años si tienen una probabilidad más alta de padecer cáncer de próstata. Un antecedente familiar de cáncer de próstata (especialmente un hermano o el padre) y ser afroamericano son los factores de riesgo más comunes.

\section{Resultados normales}

Con los resultados del examen de PSA no se puede diagnosticar el cáncer de próstata. Sólo con una biopsia de la próstata se puede diagnosticar este cáncer.

I. Un nivel de PSA normal se considera que es de $4 \mathrm{ng} / \mathrm{m}$ de sangre.

2. Para los hombres de 50 años o menos, un nivel de PSA debe estar por debajo de 2.5 en la mayoría de los casos.

3. Los hombres mayores a menudo tienen niveles de PSA ligeramente superiores a los de los hombres jóvenes.

\section{Significado de los resultados anormales}

Un nivel de PSA alto ha sido asociado con un incremento en la probabilidad de tener cáncer de próstata.

La prueba para determinar el nivel de PSA es una herramienta importante para detectar el cáncer de próstata, pero no es infalible. Otras afecciones pueden causar una elevación en el PSA, como:

I. Una próstata más grande

2. Infección de la próstata (prostatitis)

3. Infección urinaria

4. Exámenes recientes en la vejiga (cistoscopia) o próstata (biopsia)

5. Sonda vesical recientemente puesta en la vejiga para drenar orina

6. Eyaculación o relaciones sexuales recientes

7. Se debe considerar los siguientes factores al decidir el próximo paso:

8. Su edad 


\section{Sistema Genito - Urinario y Endocrino}

9. Si usted se realizó un examen de PSA en el pasado y cuánto y cuán rápido sus niveles de PSA han cambiado

10. Si se encontró un tumor en la próstata durante su examen

II. Otros síntomas que usted pueda tener

12. Otros factores de riesgo que predisponen al cáncer de próstata, tales como la raza y los antecedentes familiares

13. Los hombres en mayor riesgo posiblemente necesitan hacerse más exámenes. Estos pueden incluir:

14. Repetir la prueba de PSA, con mayor frecuencia en algún momento dentro de los siguientes tres meses. Primero, puede recibir tratamiento para la infección de la próstata.

15. Inicialmente, se hará una biopsia de la próstata para saber si los niveles de PSA están elevados o si los niveles siguen aumentando al repetir el examen.

16. Un examen de control llamado PSA libre. Cuanto más bajo sea el nivel de este examen, mayor será la probabilidad de que el cáncer de próstata esté presente.

\section{PSA Libre}

Porcentaje de PSA libre: el PSA se encuentra en la sangre principalmente en dos formas. Una forma está unida (adherida) a proteínas sanguíneas, mientras que la otra es libre (no adherida). La prueba del porcentaje de PSA libre (fPSA) es la proporción de la cantidad de PSA que circula libre, en comparación con el total del nivel de PSA. El porcentaje de PSA libre es menor en los hombres que tienen cáncer de próstata que en los hombres que no tienen esta enfermedad. Algunas veces, cuando los resultados de la prueba de PSA están en un rango intermedio o "limítrofe" (como entre 4 y 10), esta prueba se utiliza para ayudar a decidir si usted debe hacerse una biopsia de próstata. Un porcentaje menor de PSA libre significa que su probabilidad de tener cáncer de próstata es mayor, y usted probablemente debe hacerse una biopsia.

Muchos médicos recomiendan biopsias para los hombres con un porcentaje de PSA libre de $10 \%$ o menos, y recomiendan que los hombres consideren una biopsia si el porcentaje 


\section{Sistema Genito - Urinario y Endocrino}

está entre $10 \%$ y $25 \%$. El uso de estos valores límite permite detectar la mayoría de los cánceres, y ayuda a evitar biopsias de la próstata innecesarias. Esta prueba se usa ampliamente, pero no todos los médicos están de acuerdo en que el $25 \%$ sea el mejor valor límite para decidir si es necesaria una biopsia. Además, el valor límite puede cambiar dependiendo del nivel general de PSA.

\section{PSA complejo}

Esta prueba mide directamente la cantidad de PSA que está adherida a las otras proteínas (la porción de PSA que no es "libre"). Esta prueba se podría hacer en lugar de verificar el PSA total y libre, y podría dar la misma cantidad de información que las otras pruebas hechas por separado. Esta prueba está siendo estudiada para saber si ofrece el mismo nivel de precisión.

\section{Espermiograma o seminograma}

Esta prueba que se utiliza para la fertilidad masculina, consiste en el estudio de una muestra de semen por observación directa al microscopio, para analizar la presencia y el estado de los espermatozoides. Entre otros parámetros, se tiene en cuenta el volumen de la muestra, viscosidad y $\mathrm{pH}$ de los espermatozoides, y se estudian características como su morfología física, su movilidad y la presencia de anomalías.

Para la realización de esta prueba hay que seguir una serie de pautas. Además, se trata de una prueba que requiere cita previa. 


\section{Sistema Genito - Urinario y Endocrino}

\section{PATOLOGIAS DEL APARATO REPRODUCTOR FEMENINO}

\section{Quistes ovárico}

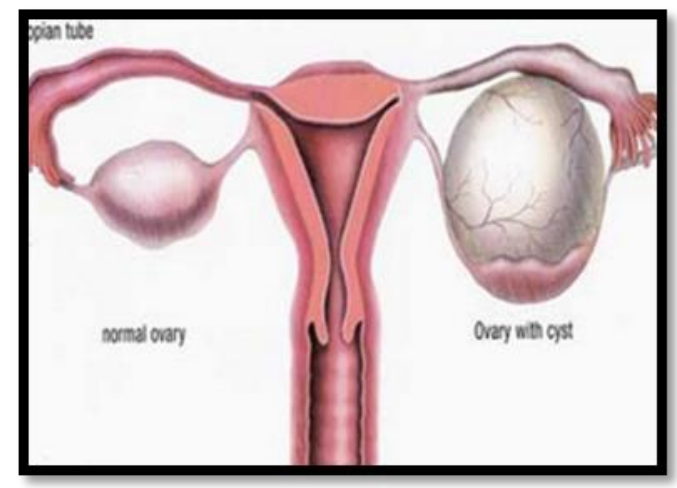

Es una formación benigna que consiste en un pequeño saco con contenido líquido. EI quiste de ovario se forma de la siguiente manera: Durante el proceso de la ovulación, los ovarios van formando folículos que crecen entre $18 \mathrm{~mm}$ y $25 \mathrm{~mm}$ aproximadamente. De ellos sólo uno alcanza la maduración suficiente para liberar el óvulo.

El resto de ellos se va reduciendo hasta desaparecer, pero cuando no lo hacen y siguen aumentando de tamaño se convierten en quistes. Son considerados quiste cuando miden entre 30 y $40 \mathrm{~mm}$.

\section{Síntomas}

Dolor en la parte baja del abdomen

Sensación de peso en la pelvis

Dispareunia (dolor en las relaciones sexuales)

Menstruaciones irregulares

Menstruaciones abundantes. 


\section{Sistema Genito - Urinario y Endocrino}

\section{Fibromas uterinos}

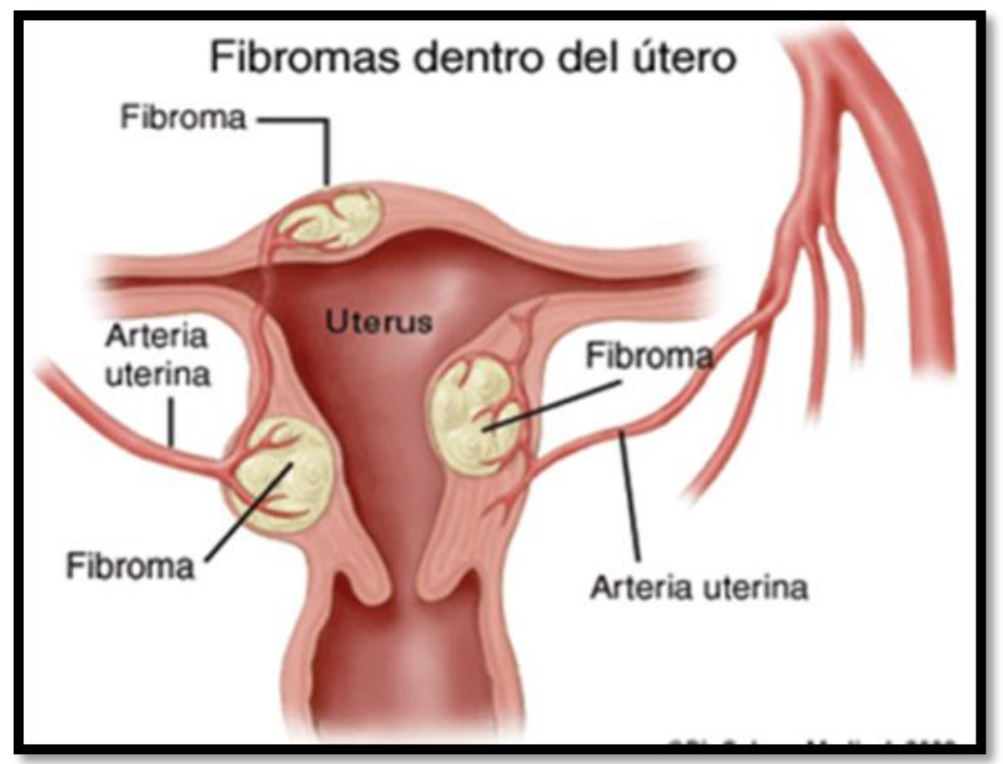

Los fibromas uterinos son tumores benignos que se forman en las paredes del útero. Consisten en una masa de células que pueden ser de tejido muscular. Los fibromas también reciben el nombre de: miomas, leiomioma o fibromioma. Los fibromas o miomas aparecen en mujeres jóvenes, esto se debe a que los estrógenos favorecen a su crecimiento. Cuando se llega a la menopausia, al disminuir la producción de esta hormona, los miomas detienen su crecimiento.

Los fibromas pueden aparecer de a uno o ser múltiples. Su tamaño también es variable, desde muy pequeños hasta los que llegan a las dimensiones de un pomelo. Se clasifican por su ubicación, los fibromas subserosos son los que crecen hacia el exterior del útero, los fibromas submucosos surgen debajo del endometrio y los fibromas intramurales crecen dentro del útero.

\section{Síntomas}

-Abundante sangrado durante la menstruación

-Fuertes dolores menstruales

-Sangrado entre períodos 


\section{Sistema Genito - Urinario y Endocrino}

-Presión en la vejiga que produce necesidad de orinar frecuentemente

-Dispareunia

-Infertilidad

-Abortos espontáneos.

\section{Enfermedad inflamatoria pélvica}

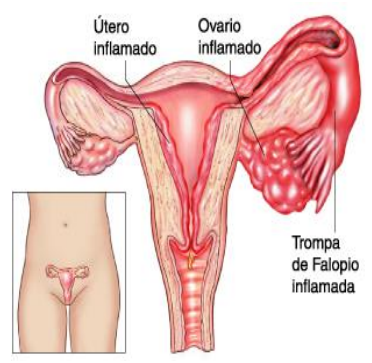

La infección de los órganos reproductores internos de la mujer se conoce como enfermedad inflamatoria pélvica EIP. Normalmente se debe a una infección bacteriana, como la clamidiasis o la gonorrea, pero también se puede producir tras el nacimiento o tras un aborto natural o provocado, a menudo en relaciones con alguien que tenga clamidia. Es infección asintomática.

La EIP acostumbra a originarse inicialmente en el útero, y se extiende por las trompas uterinas y otra estructura de la pelvis. Las mujeres que utilizan dispositivos anticonceptivos intrauterino DIU suele tener en riesgo mayor en padecer EIP. En la EIP, la infección de la trompas se denomina salpingitis. Los síntomas incluyen el marchar de sangre entre periodos, periodos irregulares y muy intensos, dolor abdominal bajo que suele agravarse durante la menstruación y durante las relaciones sexuales. Si la enfermedad es grave una mujer puede experimentar vómitos, fatiga y dolor de espalda, También son típico la fiebre elevada y una secreción vaginal similar a la pus. La EIP a veces provoca accesos que se desarrollen bloque de tejidos fibrosos en la pelvis, en las trompas uterinas o en los ovarios. La formación de cicatrices en las trompas uterinas en ovaciones causa infertilidad o embarazo ectópicos.

La enfermedad inflamatoria pélvica (EIP) es un trastorno frecuente que afecta a más de 800.000 mujeres cada año. Se caracteriza por dolor pélvico, fiebre y mucosidad vaginal. La EIP se puede producir como una inflamación aguda y se puede deber a diversos tipos de 


\section{Sistema Genito - Urinario y Endocrino}

patógenos. Cuando la infección se disemina hacia arriba a partir de la vagina, con frecuencia afecta al útero, las trompas, los ovarios y otros órganos pélvicos, con el habitual desarrollo de tejido cicatrizal y adherencias.

\section{Diagnóstico diferencial}

Debe realizarse tanto con otras patologías del tracto genital como con procesos extra genitales.

\section{Cuadros obstétricos:}

Embarazo ectópico: Es un embarazo que se desarrolla fuera de la matriz (útero). Es potencialmente mortal para la madre.

Aborto séptico: El aborto séptico es aquel asociado con infección, en el cual hay diseminación de microorganismo o toxinas que originan fiebre, endometritis (inflamación del endometrio), parametritis (inflamación del parametrio, espacio pélvico de tejido conectivo que rodea lateralmente al cérvix) y septicemia (complicación potencialmente mortal de una infección).

\section{Cuadros ginecológicos:}

I. Endometriosis: es la presencia de tejido endometrial fuera del útero. Se caracteriza por ser una enfermedad inflamatoria.

2. Quiste ovárico: Un quiste de ovario es un saco lleno de líquido o de material semilíquido que se forma en un ovario.

3. Dismenorrea intensa: es una menstruación dolorosa. Se considera una complicación de la función menstrual, caracterizada por períodos dolorosos que aparecen con la menstruación.

4. Ovulación dolorosa: Suele ser un dolor parecido al que aparece durante la menstruación. Se localiza sobre todo en la zona inferior del abdomen y bajo la pelvis. 


\section{Sistema Genito - Urinario y Endocrino}

\section{Cuadros urológicos:}

I. Cistitis: inflamación de la vejiga urinaria.

2. Pielonefritis: inflamación renal ocasionada por una infección bacteriana.

\section{Diagnóstico definitivo}

I. Exudado vaginal y exudado endocervical: son pruebas tan sencillas como fundamentales para adelantarse al diagnóstico de una posible infección viral o bacteriana en los órganos reproductores femeninos

2. Laparoscopia: Permite el drenaje de colecciones, obtención de muestras, visualización de la pelvis y anejos y permite establecer el diagnóstico diferencial con otras entidades.

Biopsia de endometrio: la presencia de células plasmáticas sugiere EIP.

\section{Candidiasis}

La infección llamada candidiasis conocida más comúnmente como hongo, está provocada por el hongo candida albicans, que se encuentra normalmente en la boca, tracto intestinal y vagina; sin embargo, su crecimiento está controlado por la bacterias inofensiva que dicho órganos también acostumbra a contener. Si las condiciones para el hongo son particularmente favorables en una zona concreta del organismo, puede llegar a crecer muchos y desplazar a las bacterias inofensivas.

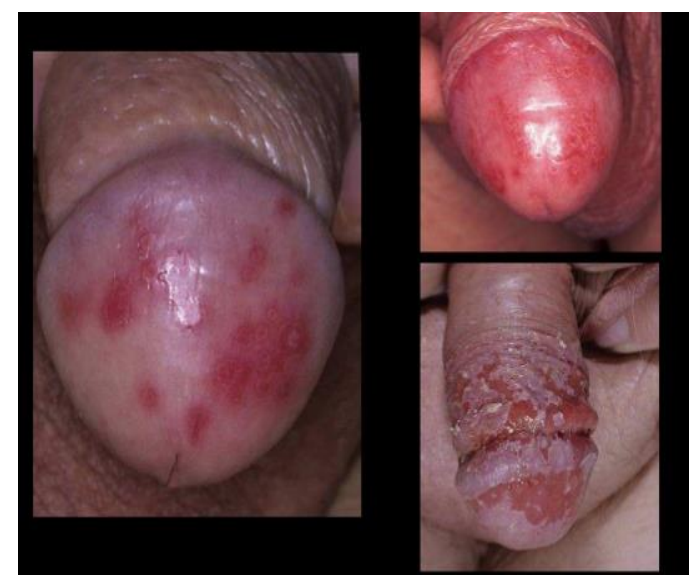




\section{Sistema Genito - Urinario y Endocrino}

El punto en que estos suceda con mayor frecuencia es la vagina, y se estima que cerca del 75\% de la mujeres han padecidos una cadidiasis vaginal en algún momento de su vida. La cadidiasis vaginal en algún momento de su vida. La cadidiasis también puede afectar al pene a pesar de que no es muy habitual a veces su causa es de transmisión sexual, pero es más frecuente debido a otros factores, como a los antibióticos, que destruye la nueva flora protectora natural del organismo, y a los cambios hormonales que se producen en la mujer embarazada.

La candidiasis vaginal puede ocasionar una secreción vagina espesa y blanca, inflamación y enrojecimiento de la vulva, dolor en las relaciones sexuales y micción frecuente y dolorosa. En los hombres puede provocar picor en el pene y secreción en el prepucio. Si la candidiasis se repite, se debe consultar al médico porque quizás sea un síntoma de diabetes.

\section{Cáncer de mama}

Una de cada ocho mujeres en los Estados Unidos tiene riesgo de sufrir cáncer de mama. Después del cáncer del pulmón, es la segunda causa de muerte entre las mujeres norteamericanas. El cáncer de mama puede aparecer en hombres, pero es raro. Entre las mujeres, no suele observarse antes de los 30 años; su incidencia se eleva rápidamente luego de la menopausia. Se estima que el $5 \%$ de los 180000 casos diagnosticados cada año en los Estados Unidos, sobre todo aquellos que se producen en mujeres más jóvenes, se originan a partir de mutaciones genéticas heredadas (cambios en el ADN).

Los investigadores identificaron dos genes que aumentan la susceptibilidad al cáncer de mama:

La mutación del cáncer de mama I, conlleva también un alto riesgo de padecer cáncer de ovario. A su vez, las mutaciones en el gen p53 incrementan el riesgo de padecer cáncer de mama tanto en hombres como en mujeres, y las mutaciones en el gen que codifica para el receptor de andrógenos se encuentran asociadas con la aparición de cáncer de mama en ciertos hombres. Debido a que el cáncer de mama generalmente no resulta doloroso hasta que alcanza estados avanzados, cualquier nódulo, sin importar cuán pequeño sea, 


\section{Sistema Genito - Urinario y Endocrino}

debe ser informado al médico en forma inmediata. La detección temprana -por autoexamen de mamas y mamografías- es la mejor forma de aumentar las posibilidades de sobrevida.

La técnica más efectiva para la detección de tumores con menos de $1 \mathrm{~cm}$ de diámetro es la mamografía, un tipo de radiografía realizada utilizando una película para radiografías muy sensible. La imagen de la mama, llamada mamografía, se obtiene mejor si se comprimen las mamas, una a la vez, utilizando dos placas horizontales. Un método auxiliar para evaluar las anormalidades de las mamas es la ecografía. A pesar de que la ecografía no puede detectar tumores con menos de $\mathrm{I} \mathrm{cm}$ de diámetro (que si pueden detectarse en la mamografía), puede utilizarse para determinar si un nódulo es benigno, un quiste lleno de líquido o un tumor solido (y posiblemente maligno).

Entre los factores que aumentan el riesgo de desarrollar cáncer de mama se encuentran: I) antecedentes familiares de cáncer de mama, especialmente en madres o hermanas; 2) nuliparidad (nunca haber dado a luz) o haber tenido el primer hijo luego de los 35 años; 3 ) cáncer previo en una mama; 4) exposición a radiaciones ionizantes, como rayos x; 5) ingestión excesiva de alcohol; y 6) tabaquismo. El tratamiento del cáncer de mama se puede realizar con terapia hormonal, quimioterapia, radioterapia, tumorectomia (extirpación del tumor y del tejido circundante). Mastectomía radical modificada o una combinación de estos procedimientos. 


\section{Sistema Genito - Urinario y Endocrino}

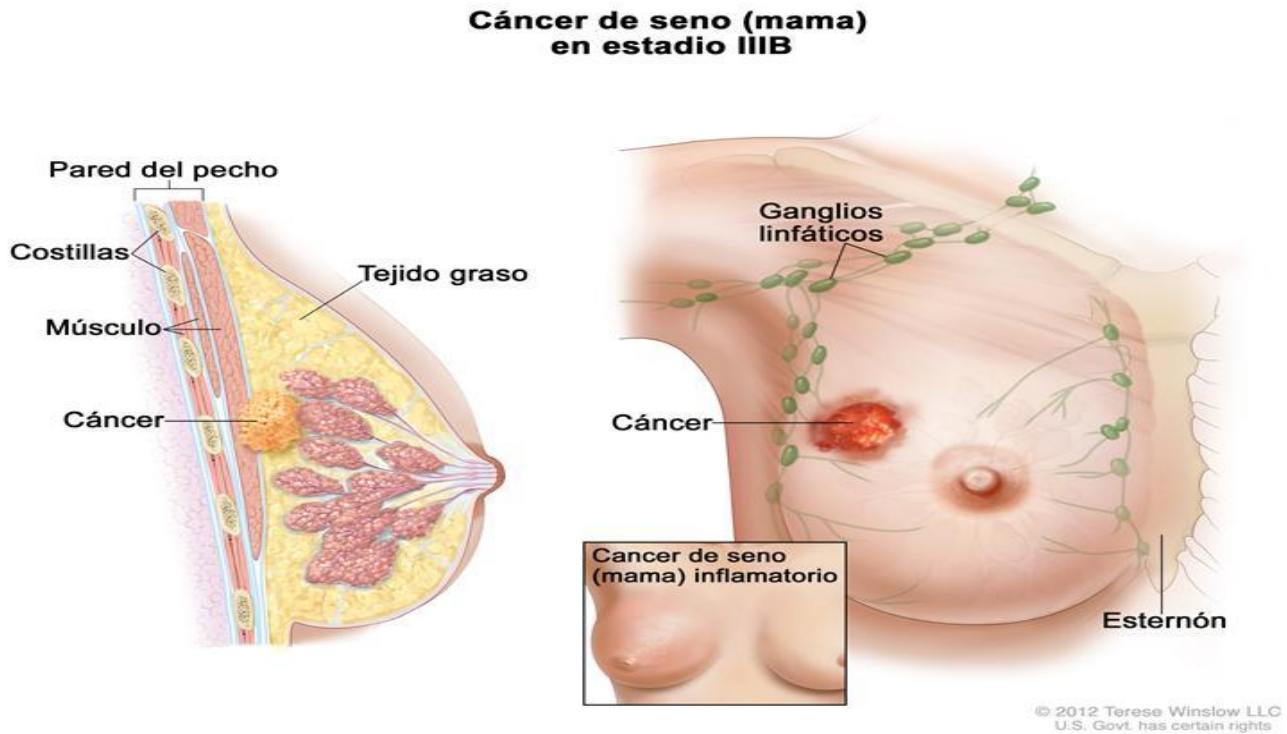

\section{Cáncer de útero}

Es un tipo de cáncer que se puede encontrar en el cuello uterino, o el endometrio, aunque se suele utilizar en el cuello, el cáncer del cuello uterino es más frecuente entre las mujeres que empezaron a tener relaciones sexuales a edad temprana, las que mantuvieron gran número de parejas sexuales o las que han padecido algún tipo de verruga vírica genital. Las células pre cancerígenas son detectable mediante Screening.

Los síntomas de cáncer de cuello incluyen una secreción rosácea por la vagina, hemorragias tras las relaciones sexuales, manchas y, más adelante una secreción vaginal maloliente, teñida de sangre. Un cáncer en cualquier otro punto del útero acostumbra a empezar en el endometrio, desde donde acaba por invadir todo el órgano. Desde ahí se puede extender a las trompas uterinas, ovarios, ganglios linfáticos y a otros órganos. Los tumores del endometrio y de útero crecen y se propagan con gran lentitud, por lo que son más fáciles de tratar que otros tipos de cáncer.

Determinados factores parecen aumentar la susceptibilidad a la enfermedad, como ovulaciones repetidas (ovulación cada mes, durante un periodo prolongado). Esto puede ocurrir en mujeres que han tenido un embarazo precoz, una menopausia tardía o en las que nunca han tenido hijos. Además la exposición a elevados niveles de estrógenos. 


\section{Sistema Genito - Urinario y Endocrino}

La obesidad, asociada a niveles elevados de estrógenos y diabetes mellitus, también aumenta el riesgo de cáncer uterino. Los síntomas de cáncer uterino incluyen hemorragias tras la menopausia, o periodos excesivamente intensos en las mujeres que aún tienen menstruación. También puede haber una secreción vaginal rosácea o marrón maloliente, y dolor intermitente similar al menstruar.

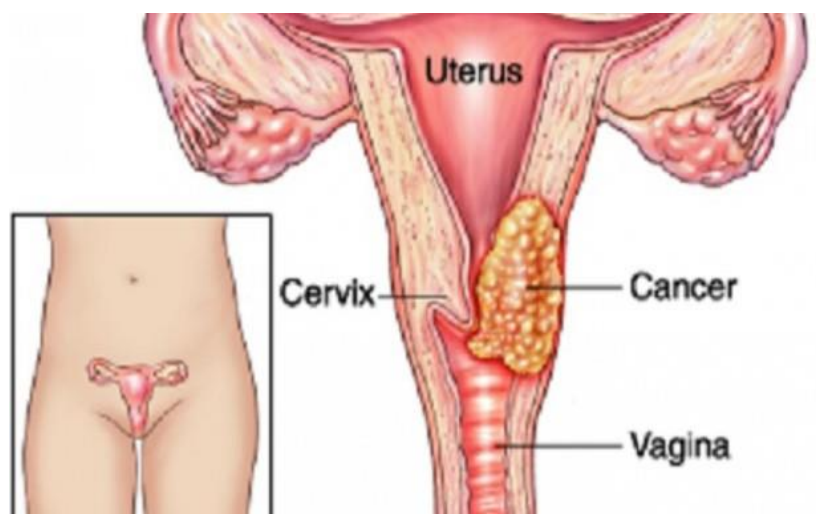

El cáncer de cuello uterino se origina en las células que revisten el cuello del útero. El cuello del útero es la parte inferior del útero (la matriz). Algunas veces se le llama cervix uterino. El cuerpo del útero (parte superior) es el lugar donde se desarrolla un el feto. El cuello uterino conecta el cuerpo del útero con la vagina (el canal por donde nace el bebé).

\section{Diagnóstico diferencial}

La mayoría de las mujeres no tienen signos ni síntomas de pre cáncer. En muchas mujeres con cáncer de cuello uterino en estadio temprano, los síntomas generalmente pueden verse. En mujeres con cáncer avanzado y metastásico, los síntomas pueden ser más graves dependiendo de los tejidos y órganos a los que se ha diseminado la enfermedad. La causa de un síntoma puede ser una afección médica diferente que no es cáncer, por lo que las mujeres deben buscar atención médica si presentan un nuevo síntoma que no desaparece. Cualquiera de los siguientes podría ser un signo o síntoma de cáncer:

I. Manchas de sangre o sangrado leve entre o después de la menstruación

2. Sangrado menstrual que es más prolongado y abundante que lo habitual

3. Sangrado después del coito, el lavado genital o el examen pélvico

4. Mayor secreción vaginal 


\section{Sistema Genito - Urinario y Endocrino}

5. Dolor durante las relaciones sexuales

6. Sangrado después de la menopausia

7. Dolor de espalda y/o pélvico persistente y sin razón aparente.

\section{Diagnóstico definitivo}

En la mayor parte de los tipos de cáncer, una biopsia es la única manera segura para que el médico determine si un área determinada del cuerpo tiene cáncer. Durante la biopsia, el médico toma una pequeña muestra de tejido para hacerle pruebas en un laboratorio. Si no se puede realizar una biopsia, el médico puede sugerir que se lleven a cabo otras pruebas que ayuden a establecer un diagnóstico. Esta lista describe opciones para el diagnóstico de este tipo de cáncer. No todas las pruebas mencionadas a continuación se utilizarán para todas las personas. Algunas o todas estas pruebas pueden ayudar al médico a planificar el tratamiento de su cáncer. El médico puede considerar estos factores al elegir una prueba de diagnóstico:

I. Tipo de cáncer que se sospecha

2. Sus signos y síntomas

3. Su edad y afección médica

4. Los resultados de pruebas médicas anteriores.

Además del examen físico, se pueden utilizar las siguientes pruebas para diagnosticar el cáncer de cuello uterino:

Examen pélvico. En este examen, el médico palpa el útero, la vagina, los ovarios, el cuello uterino, la vejiga y el recto para determinar si hay cambios inusuales. Por lo general, la prueba de Papanicolaou se realiza simultáneamente.

Prueba de Papanicolaou. Durante una prueba de Papanicolaou, el médico raspa ligeramente la parte externa del cuello uterino y la vagina, $y$ toma muestras de las células para su análisis. Los métodos mejorados de pruebas de Papanicolaou han facilitado a los médicos la detección de células cancerosas. Las pruebas de Papanicolaou tradicionales pueden ser difíciles de leer, porque las células pueden haberse secado, estar cubiertas con moco o sangre, o estar aglutinadas en el portaobjetos. 


\section{Sistema Genito - Urinario y Endocrino}

La prueba de citología de base líquida, a menudo denominada ThinPrep o SurePath, transfiere una capa delgada de células sobre un portaobjetos después de retirar la sangre o moco de la muestra. La muestra se preserva, de modo que al mismo tiempo se pueden realizar otras pruebas, como la prueba de HPV (ver Prevención).

En los exámenes de detección por computadora, con frecuencia denominados AutoPap o FocalPoint, se usa una computadora para explorar la muestra a fin de detectar la presencia de células anormales.

Examen pélvico bajo anestesia. En casos en los que es necesario planificar un tratamiento, el especialista puede volver a examinar el área pélvica mientras la paciente se encuentra bajo anestesia para ver si el cáncer se ha diseminado a los órganos que están cerca del cuello uterino, incluidos el útero, la vagina, la vejiga o el recto.

Radiografía. Una radiografía es un modo de crear una imagen de las estructuras internas del cuerpo usando una pequeña cantidad de radiación. La urografía intravenosa o pielografía es un tipo de radiografía que se utiliza para visualizar los riñones y la vejiga.

Exploración por tomografía computarizada (CT O CAT). Una exploración por CT crea una imagen tridimensional del interior del cuerpo utilizando rayos $X$ que se toman desde diferentes ángulos. Una computadora combina estas imágenes en una vista detallada de cortes transversales que muestra cualquier anormalidad o tumor. Una exploración por CT se puede utilizar para medir el tamaño del tumor. En ocasiones, se administra un tinte especial, denominado medio de contraste, antes de la exploración, a fin de obtener mejores detalles en la imagen. Este tinte se puede inyectar en las venas o puede ser administrado en forma de pastilla para tragar.

Imágenes por resonancia magnética (MRI). Una MRI usa campos magnéticos, en lugar de rayos $\mathrm{X}$, para producir imágenes detalladas del cuerpo. Las MRI se pueden usar para medir el tamaño del tumor. Antes de la exploración, se administra un tinte especial denominado medio de contraste a fin de crear una imagen más clara. Este tinte se puede inyectar en las venas o puede ser administrado en forma de pastilla para tragar. 


\section{Sistema Genito - Urinario y Endocrino}

\section{Cáncer de ovario}

A pesar de ser la sexta forma más común de cáncer en las mujeres, el cáncer de ovario es la principal causa de muerte de todos los cáncer ginecológicos (excepto el de mama) debido a que es difícil detectarlo antes de que haga metástasis (se extienda) más allá de los ovarios.

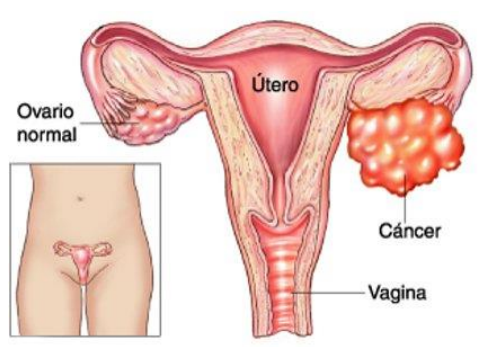

Los factores de riesgo asociados al cáncer de ovario incluyen la edad (habitualmente por encima de los 50 años); la raza (las personas blancas son las que tienen mayor riesgo); los antecedentes familiares de cáncer de ovario; más de 40 años de ovulación activa; nuliparidad o primer embarazo después de los 30 años de edad; una dieta rica en grasas, baja en fibras y deficiente de vitamina $A$; $y$ exposición prolongada al asbesto o al talco.

El cáncer de ovario temprano no causa síntomas o solo algunos síntomas leves asociados a otros inespecíficos, como malestar abdominal, pirosis, náuseas, pérdida del apetito, meteorismo y flatulencia. Los signos y síntomas de los estadios más tardíos incluyen distensión abdominal, dolor abdominal y/o pelviano, alteraciones gastrointestinales persistentes, complicaciones urinarias, irregularidades menstruales y sangrado menstrual profuso.

Es una forma de cáncer que tiende a afectar a mujeres de más de 50 años, a pesar de también puede afectar a otras más jóvenes. Es difícil de detectar, porque los ovarios se encuentran muy metidos en el bajo abdomen. No suele provocar síntomas hasta que está avanzado, apareciendo una hinchazón abdominal, acompañada de incomodidad, nauseas, hemorragias vaginales anormales, cambios en los hábitos de defecación, pérdida de peso y una salud debilitada. Se desconoce cuál es la causa del cáncer de ovario, pero se cree que existe un factor genético que ayuda a que se desarrolle la enfermedad. Las mujeres que 


\section{Sistema Genito - Urinario y Endocrino}

nunca han tenido hijos o que han sido sometidas a un tratamiento de infertilidad, tienen un mayor riesgo.

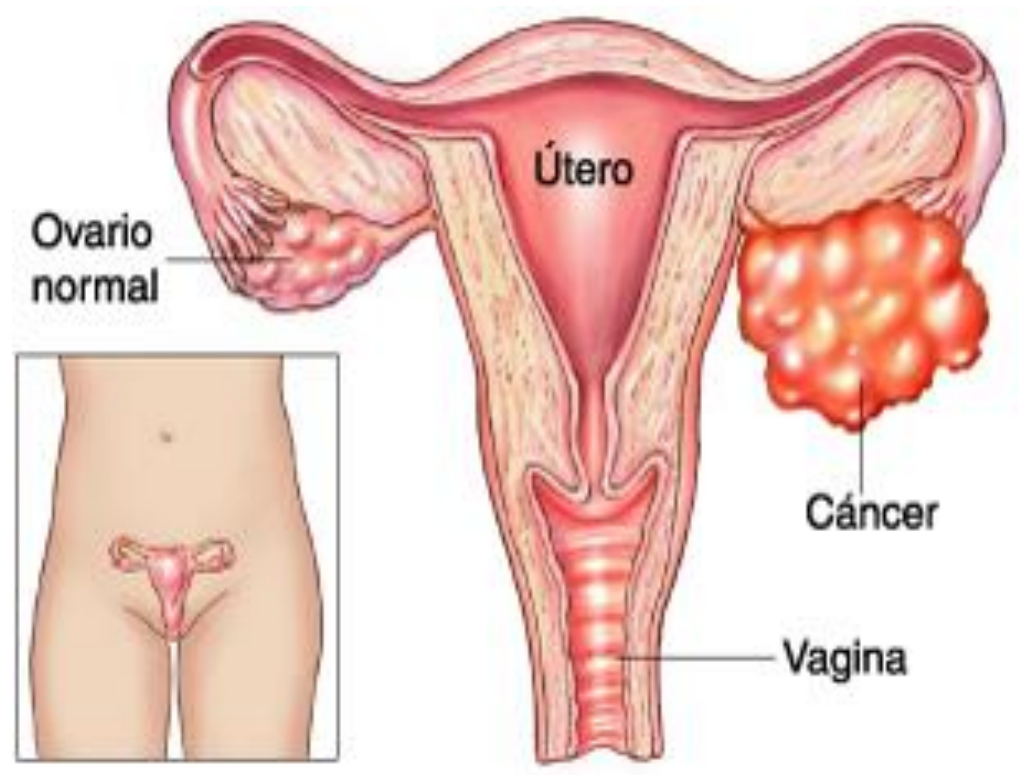

\section{Cáncer cervical}

El cáncer cervical, carcinoma del cuello uterino, comienza como una displasia cervical, con cambios en la forma, crecimiento y número de las células cervicales. Las células pueden regresar a la normalidad o progresar hacia el cáncer. En la mayoría de los casos, el cáncer cervical puede detectarse en sus estadios más tempranos, por medio de un examen de Papanicolaou. Cierta evidencia vincula el cáncer cervical con el virus que causa las verrugas genitales, el virus del papiloma humano (HPV). El riesgo aumentado se asocia con el número de parejas sexuales, con haber tenido la primera relación sexual en edades tempranas y el tabaquismo. 


\section{Sistema Genito - Urinario y Endocrino}

\section{Vaginitis y vulvovaginitis}

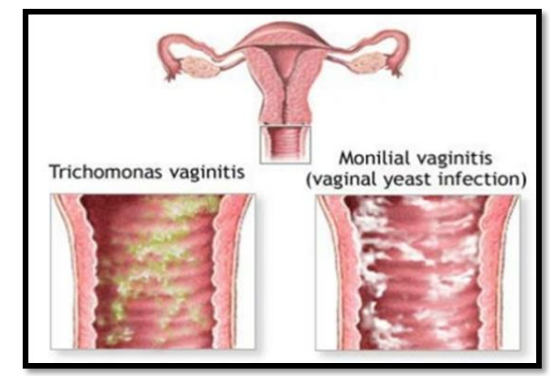

La vaginitis es la inflamación o infección de la vagina. Las causas de que se produzcan irritaciones en vulva y vagina pueden ser el uso de sustancias como las que contienen las duchas o desodorantes vaginales, espermicidas o productos con los que se realiza la higiene. Las vulvovaginitis frecuentemente son causadas por Candidiasis (hongos), Tricomoniasis (parásitos). En muchos casos son provocadas por enfermedades de transmisión sexual o por una higiene deficiente. En los casos de mala higiene se presenta flujo vaginal marrón verdoso y maloliente, producto de una infección causada por bacterias que se encuentran en el recto y son trasladadas a la vagina luego de la defecación.

\section{Síntomas}

-Enrojecimiento en la zona

-Inflamación en vulva o vagina

-Ardor o picazón

-Irritación

-Flujo vaginal anormal

-Ardor al orinar (Disuria) 


\section{Sistema Genito - Urinario y Endocrino}

-Ulceras vaginales o vulvares.

Por tanto, la vaginitis o vulvovaginitis, es una inflamación o infección de la vagina. También puede afectar la vulva, la parte externa de los genitales de la mujer. La vaginitis puede causar picazón, dolor, mucosidad y olor. Es común, especialmente en las mujeres en edad reproductiva. Por lo general, ocurre cuando hay un cambio en el equilibrio de bacterias o levaduras que normalmente se encuentran en su vagina.

\section{Diagnóstico diferencial}

Vaginitis bacteriana: es una infección bacteriana que ocurre cuando se pierde el equilibrio entre los diferentes tipos de bacterias saludables que están en la vagina y estas proliferan. Suele ser causada por una bacteria llamada Gardnerella vaginalis, que es el tipo de bacteria más común en la vagina.

Vaginitis atrófica: está causada, fundamentalmente, por una disminución de los estrógenos, que son la principal hormona sexual femenina. Las manifestaciones más frecuentes de la vaginitis atrófica son: sequedad vaginal, dolor o malestar al mantener relaciones sexuales (dispareunia), escozor o ardor al orinar, incontinencia urinaria, prolapso vaginal; adelgazamiento de las paredes vaginales, ardor vaginal.

Vaginitis por cuerpo extraño: Los cuerpos extraños (por lo general tampones o condones retenidos) causan descargas vaginales de mal olor. El tratamiento consiste en la remoción, para lo cual los fórceps en anillo podrían ser útiles. No se necesitan tratamientos adicionales.

Vaginitis alérgica: se produce cuando se da una reacción exagerada a un componente externo (el alérgeno) en esta zona íntima de la mujer. Los síntomas más comunes se manifiestan clínicamente con alteraciones significativas en esta zona como escozor, prurito, edema o eccema.

\section{Diagnóstico definitivo}

Revisar historia clínica: esto incluye tus antecedentes de infecciones de transmisión sexual o infecciones vaginales. 


\section{Sistema Genito - Urinario y Endocrino}

Realizar un examen pélvico: durante el examen pélvico, el médico puede usar un instrumento (espéculo) para mirar dentro de la vagina en busca de signos de inflamación y flujo anormal.

Tomar una muestra para análisis de laboratorio: el médico podría tomar una muestra de moco cervical o flujo vaginal para enviarla a un laboratorio para su análisis y así confirmar qué tipo de vaginitis tienes.

Realizar una prueba de PH: el médico podría analizar tu $\mathrm{pH}$ vaginal aplicando una tira reactiva o un papel para medir el $\mathrm{pH}$ a la pared vaginal. Un $\mathrm{pH}$ elevado puede indicar la presencia de vaginosis bacteriana o tricomoniasis. Sin embargo, la prueba de $\mathrm{pH}$ por sí sola no es un método de diagnóstico confiable.

\section{Flujo vaginal}

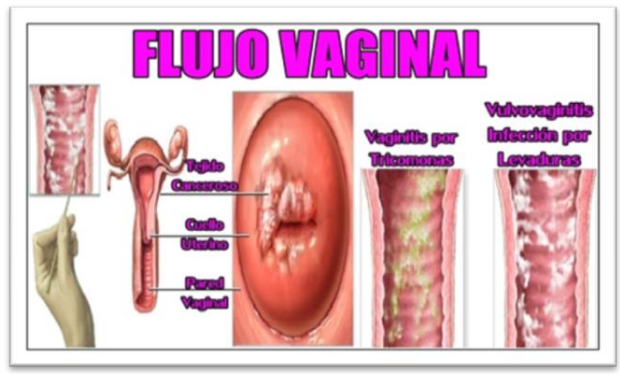

Es una secreción que proviene de la vagina y del cuello del útero. Normalmente en la primer etapa del ciclo menstrual es incoloro y va aumentando a medida que se acerca la ovulación, luego va disminuyendo, tornándose más espeso y más oscuro. Cada mujer tiene un flujo vaginal que es normal en ella, pero se debe prestar atención a los cambios que pueden suceder como por ejemplo un cambio de color, olor fuerte, mucha cantidad, picazón o ardor a nivel vaginal o vulvar. A continuación detallamos los problemas más comunes de flujo vaginal, descenso vaginal o leucorrea. Flujo de color blanco grisáceo o 


\section{Sistema Genito - Urinario y Endocrino}

flujo gris con olor a pescado. En este caso estamos en presencia de una bacteria llamada Gardnerella.

Flujo espeso amarillo verdoso. Este flujo vaginal es provocado por los parásitos Tricomonas. Puede presentar irritación en los genitales externos. Flujo blanco espeso y grumoso es producto de un hongo llamado Cándida.

\section{Cistitis}

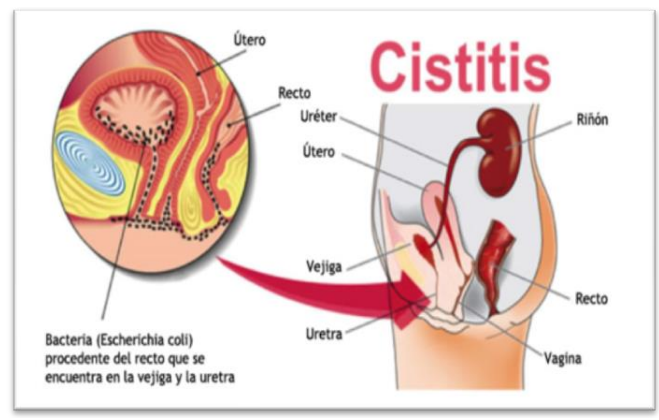

La Cistitis es la inflamación de la vejiga.

La causa de la Cistitis es la bacteria E.coli, que se encuentra normalmente en el intestino, es una de las principales causantes de la Cistitis.

Estas bacterias se eliminan mediante la orina, pero cuando no se orina lo suficiente, o las bacterias se multiplican demasiado rápido se produce la infección. Generalmente, es una infección que se localiza inicialmente en la uretra y luego sube hasta la vejiga.

\section{Síntomas}

Necesidad de orinar con mucha frecuencia

Sensación continua de vejiga llena 


\section{Sistema Genito - Urinario y Endocrino}

Ardor al orinar (Disuria)

Ardor en la zona uretral

Presión en la pelvis

Orina turbia y con olor fuerte

Aparición de sangre en la orina (Hematuria).

\section{Vulvitis}

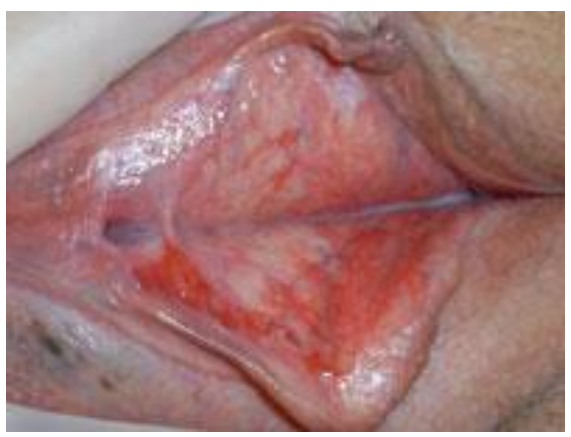

La vulvitis es una inflamación de la vulva, los labios de piel suave afuera de la vagina. Esto no es una condición, sino más bien un síntoma que resulta de tener enfermedades, infecciones, heridas, alergias y otros irritantes. El diagnóstico y el tratamiento de esta condición pueden ser frustrantes porque es difícil, con frecuencia, determinar la causa específica de la irritación. La vulva es vulnerable a muchas inflamaciones producidas por microbios inespecíficos y a trastornos dermatológicos.

Hay muchas formas específicas de infección vulvar producidas por enfermedades de transmisión sexual. Dentro de los agentes infecciosos más frecuentes: el virus del papiloma, herpes genital, infección supurativa gonocócica de las glándulas vulvovaginales, sífilis y la vulvitis candidiásica. 


\section{Sistema Genito - Urinario y Endocrino}

\section{Trastornos epiteliales no neoplásicos}

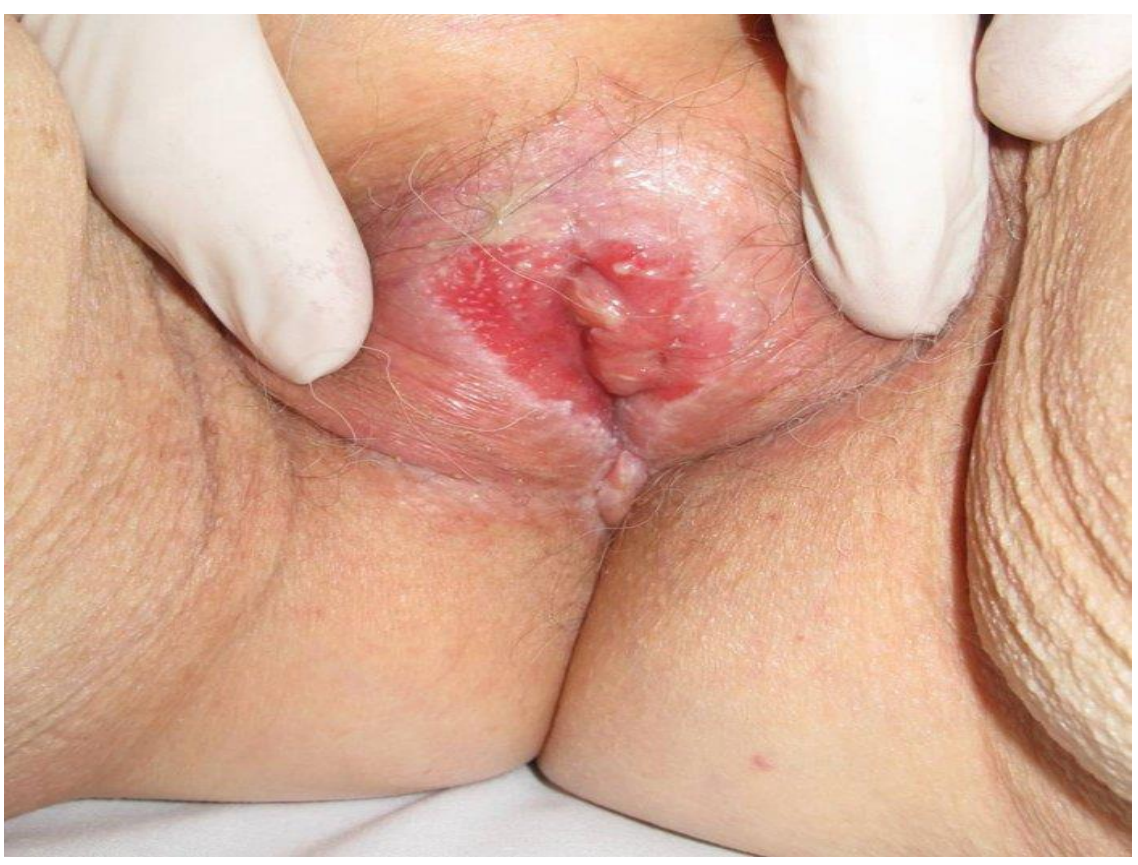

El epitelio de la mucosa vulvar puede sufrir adelgazamiento atrófico o engrosamiento hiperplásico. Hay dos formas de trastornos epiteliales no neoplásicos:

Liquen escleroso y

Liquen simple crónico.

Ambos pueden coexistir en diferentes áreas en la misma persona y pueden tener el aspecto macroscópico de lesiones blancas despigmentadas, llamadas leucoplasia. Se caracteriza por:

-Adelgazamiento de la epidermis y la desaparición de las crestas epidérmicas

-Degeneración hidrópica de las células basales

-Hiperqueratosis superficial y fibrosis dérmica con un escaso infiltrado perivascular de células inflamatorias mononucleares. 


\section{Sistema Genito - Urinario y Endocrino}

\section{Cervicitis}

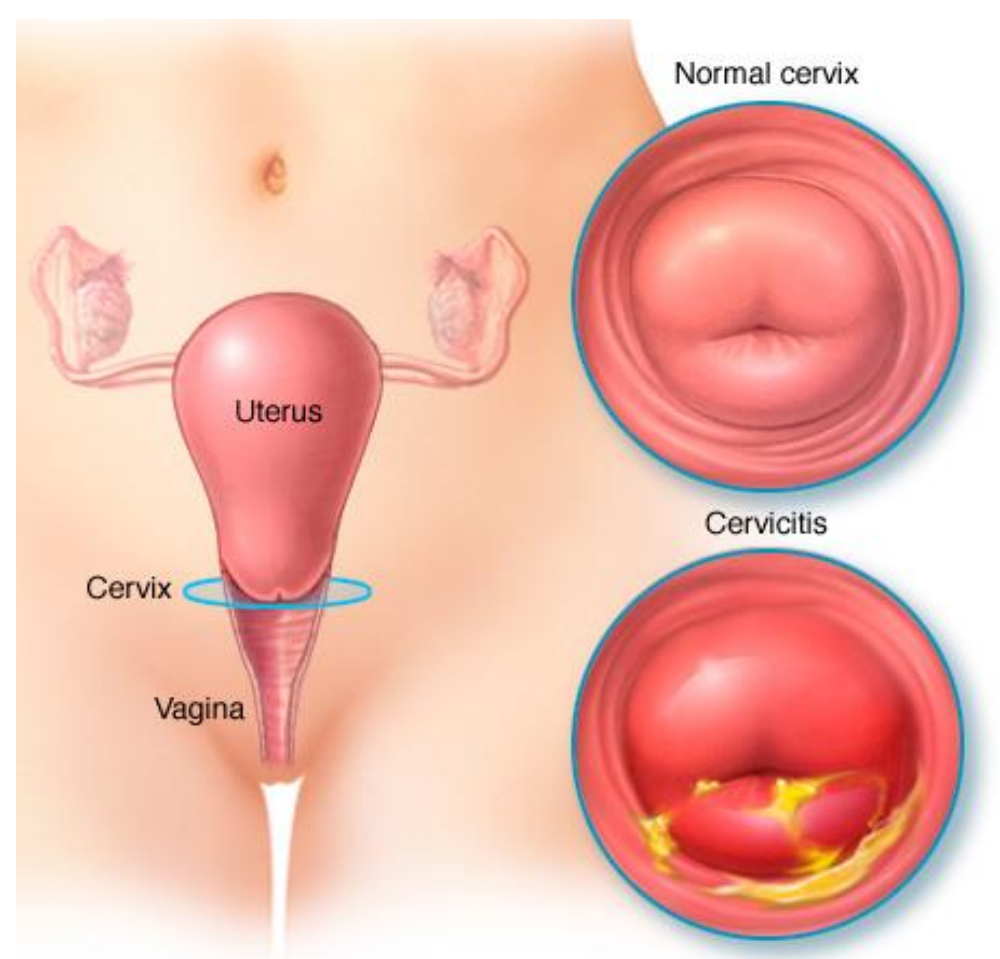

Las inflamaciones del cuello del útero son sumamente frecuentes y se asocian con una secreción vaginal mucopurulenta o purulenta. El estudio citológico de esta secreción revela leucocitos y atipia inflamatoria de las células epiteliales descamadas, así como posibles microorganismos. La cervitis puede ser una enfermedad de trasmisión sexual.

\section{Causas}

-Puede estar causada por infecciones específicas como gonococos, clamidias, Trichomonas vaginalis, Candida y Micoplasma, o bien por aerobios o anaerobios endógenos de la vagina (cervicitis inespecífica).

-La cervitis aguda es más frecuente en el puerperio.

-La cervitis crónica es más frecuente, con frecuencia es de causa desconocida. 


\section{Sistema Genito - Urinario y Endocrino}

\section{Endometritis}

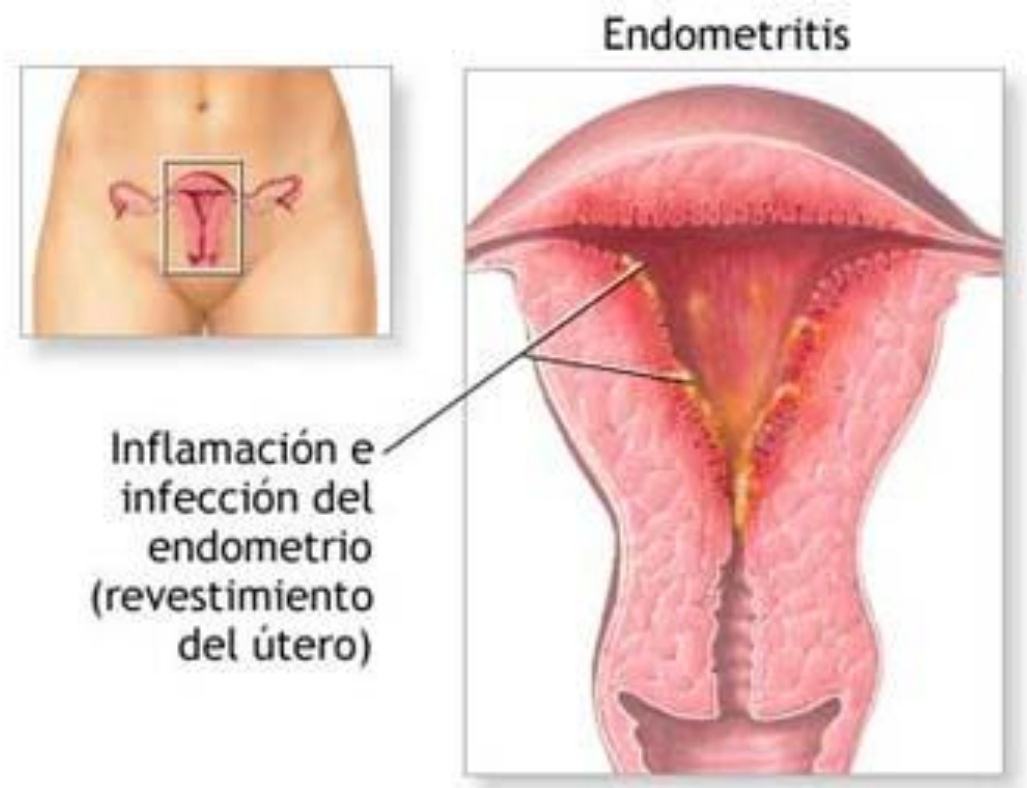

La inflamación del endometrio se considera una parte del espectro más amplio de la enfermedad inflamatoria pélvica. Puede asociarse con retención de los productos de la concepción posterior a abortos o a parto, o a un cuerpo extraño, como un dispositivo intrauterino. Se clasifica como aguda o crónica según haya una respuesta predominante neutrofílica o linfoplasmocitaria. La endometritis aguda es debida, generalmente, a $\mathrm{N}$. gonorrhoeae o a C. trachomatis. 


\section{Sistema Genito - Urinario y Endocrino}

\section{Endometriosis}

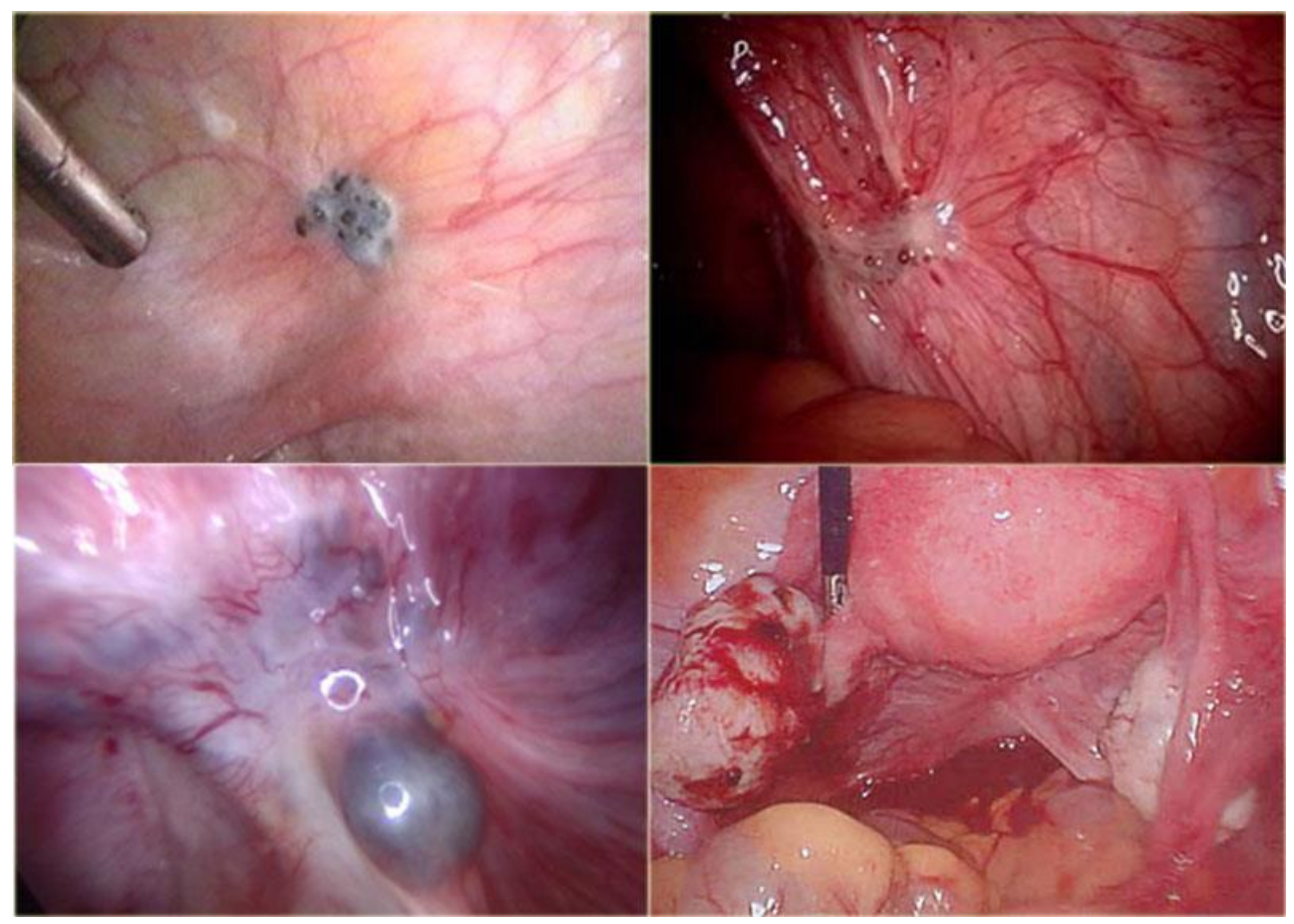

La endometriosis se caracteriza porque las glándulas y la estroma endometrial, se hallan fuera del endomiometrio. Se da en hasta un 10\% de las mujeres en edad fértil y en casi la mitad de las infértiles. Es una causa frecuente de dismenorrea y dolor pélvico, y puede presentarse como una masa pélvica llena de sangre en vías de degeneración (quiste de chocolate). Contiene casi siempre endometrio funcionante, que sufre hemorragia cíclica. Como se acumula sangre en esos focos aberrantes, suelen tener un aspecto macroscópico como nódulos o implantes rojo azulados a amarillo amarronados. 


\section{Sistema Genito - Urinario y Endocrino}

\section{Ovarios poliquísticos}

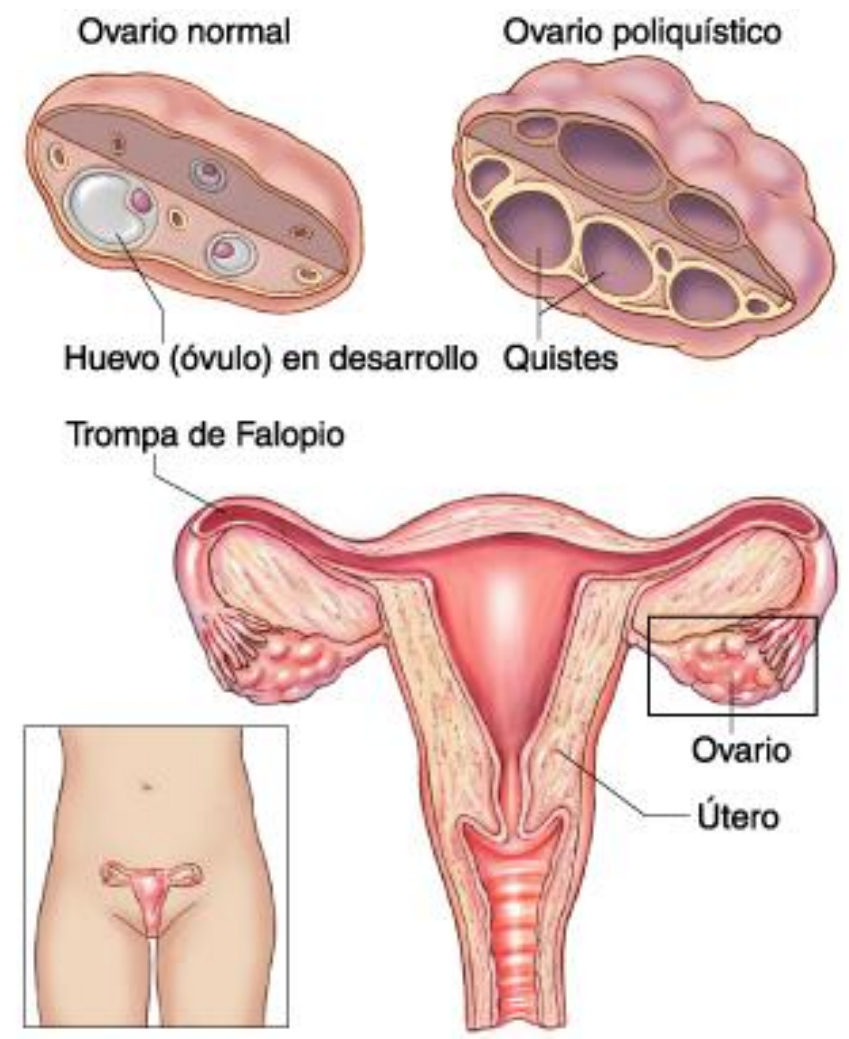

En mujeres jóvenes puede aparecer, infertilidad y, a veces, obesidad, secundariamente a la producción excesiva de estrógenos y andrógeno. Los ovarios suelen tener un tamaño el doble de lo normal, son gris blanquecino con una corteza externa lisa. Las principales anomalías en la mayoría de las pacientes son una producción excesiva de andrógenos, concentraciones elevadas de hormona luteinizante y bajas concentraciones de hormona foliculoestimulante

\section{Prolapso uterino}

El prolapso uterino (prolapso = caída o descenso) puede producirse como resultado de un debilitamiento de los ligamentos y la musculatura que sostienen al útero, asociado con 


\section{Sistema Genito - Urinario y Endocrino}

la edad o enfermedades, al parto vaginal traumático, al esfuerzo crónico por tos o movimientos intestinales dificultosos o a tumores pelvianos. El prolapso puede clasificarse como de primer grado (leve), en el cual el cuello permanece en la vagina; de segundo grado (marcado), en el cual el cuello protruye a través de la vagina hacia el exterior; y de tercer grado (completo), en el cual el útero entero se encuentra fuera de la vagina.

Según el grado de prolapso, el tratamiento puede implicar ejercicios pelvianos, dieta si la paciente tiene sobrepeso, ablandamiento de las deposiciones para minimizar el esfuerzo durante la defecación, terapia con pesario (colocación de un dispositivo de goma alrededor del cuello uterino, que ayuda empujar el útero) o cirugía.

\section{Alteraciones menstruales}

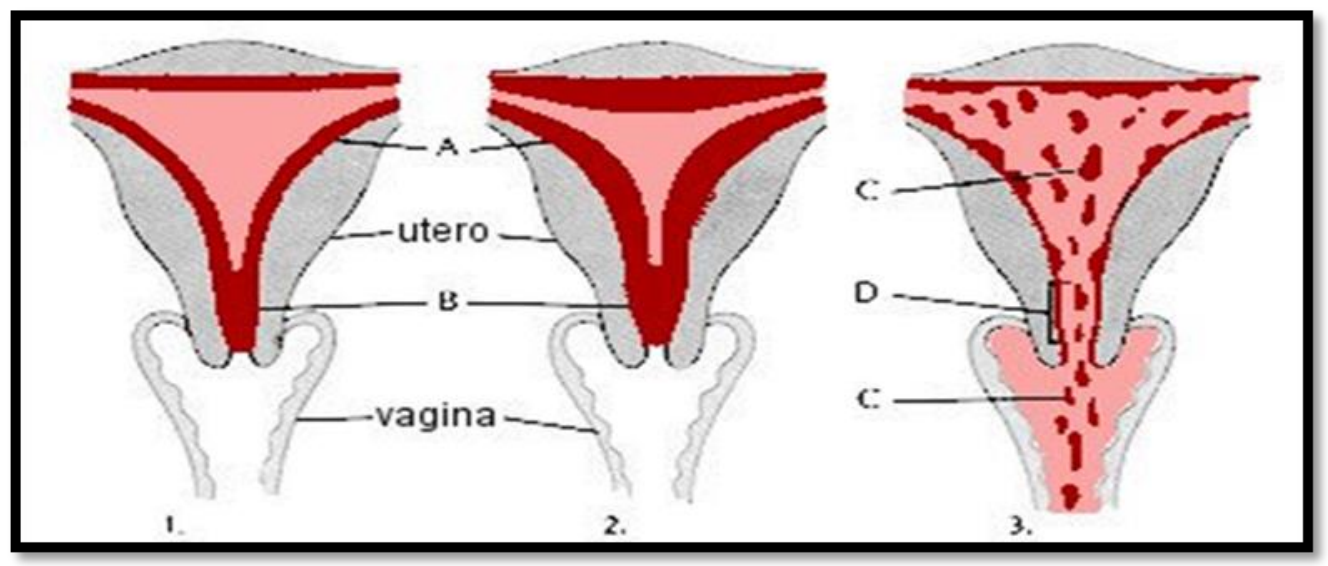

La regla es un proceso natural y necesario. Tras la primera regla las alteraciones son "habituales" porque pasa algún tiempo en que el organismo se regula. Sin embargo, cuando tarda más de 40 días en aparecer la regla o se trata de un periodo irregular o estamos hablando de un embarazo. Algunos trastornos comunes de la menstruación, los cuales pueden dividirse por su frecuencia, duración y cantidad. 


\section{Sistema Genito - Urinario y Endocrino}

\section{Trastornos del ritmo o frecuencia}

\section{Amenorrea}

Es la falta de menstruación en una mujer, bien porque una adolescente no haya llegado a menstruar, o bien porque la regla desaparezca por alguna causa que, en ambos casos, es necesario determinar. $O$ también es la usencia de 2 o más ciclos menstruales consecutivos.

\section{Tipos de amenorrea}

Las amenorreas se pueden dividir en amenorreas primarias y amenorreas secundarias, $y$ cada uno de estos tipos de amenorreas se debe a diferentes causas.

Las amenorreas primarias son poco frecuentes. Podemos hablar de amenorrea primaria cuando al cumplir los 16 años una mujer no ha menstruado ni ha desarrollado caracteres sexuales secundarios (si tiene caracteres sexuales secundarios puede ser normal no menstruar hasta los 18 años).

Las amenorreas secundarias son mucho más frecuentes que las amenorreas primarias, sobre todo porque en este grupo se incluyen las amenorreas fisiológicas, es decir, las falta de menstruación en la mujer por causas naturales. La falta de menstruación de forma puntual en una mujer no es una amenorrea, sólo podemos hablar de amenorrea secundaria cuando falta la menstruación durante al menos seis meses seguidos en una mujer que antes ya había tenido la regla.

\section{Síntomas de amenorrea}

El síntoma principal de amenorrea es la ausencia de menstruación en la mujer. El resto de síntomas que presente puede orientar al médico hacia la causa de esa amenorrea (vómitos en el embarazo, por ejemplo). Excepto en las situaciones fisiológicas, la amenorrea es una manifestación de una alteración hormonal subyacente $y$, en la mayoría de los casos, la supresión de estrógenos y progesterona es la clave del problema. Por ello, muchas mujeres sufren a la vez regresión de caracteres sexuales (disminución de las mamas, desaparición de vello) y alteraciones metabólicas de importancia, siendo la más importante 


\section{Sistema Genito - Urinario y Endocrino}

la osteoporosis. Por ello, en una mujer con una amenorrea prolongada se debe estudiar la densidad ósea de sus huesos, sea cual sea su edad.

Otros síntomas que en ocasiones acompañan a la amenorrea, aunque siempre dependen de la causa que haya provocado la falta de menstruación, son: sequedad vaginal, aumento o pérdida de peso importante, hirsutismo, galactorrea (cuando las mamas de una mujer que no está embarazada secretan leche materna), molestias abdominales cíclicas sin sangrado, dolor de cabeza, acné.

\section{Proiomenorrea}

La menstruación frecuente es aquella en que el sangrado se presenta en ciclos cortos, que duran menos de 21 días.

\section{Causas de la Proiomenorrea}

I. Enfermedades que ocasionan variaciones en los niveles hormonales pueden generar menstruaciones demasiado frecuentes. Algunas enfermedades importantes que deberán investigarse son:

2. Crecimiento o engrosamiento del endometrio

3. Cáncer del útero

4. Miomas uterinos

5. Pólipos uterinos

6. Endometriosis: crecimiento excesivo del endometrio, que puede extenderse fuera del útero.

7. Alteraciones en la hipófisis

8. Alteraciones en la glándula tiroides

9. Otras causas como lesiones, traumatismos, enfermedades de la sangre

10. Uso de medicamentos

II. Uso de DIU (dispositivos intrauterinos)

12. Cambios en la dieta, peso, ejercicio

13. Estrés psíquico y/o físico. 


\section{Sistema Genito - Urinario y Endocrino}

\section{Opsomenorrea}

Ciclos de más de 35 días o retraso de más de 5 días en el inicio de la menstruación.

Trastornos por su duración

\section{Polimenorrea}

Se llama polimenorrea a una enfermedad de la regularidad menstrual caracterizada por un sangrado irregular. La mujer que sufre de esta enfermedad tiene períodos breves, con una duración menor a los $2 \mathrm{I}$ días, y tiene por lo tanto un ciclo excesivamente breve.

\section{Oligomenorrea}

Sangrado menstrual menor de 3 días de duración.

\section{Trastornos por su cantidad}

Hipermenorrea: Reducción del número de menstruaciones (con un intervalo superior a 34 días entre dos períodos de regla) o de la cantidad de flujo menstrual. Puede tratarse de un carácter constitucional y sin significado patológico, o deberse a trastornos endocrinos, genitales o de otro tipo. Aumento considerable en la cantidad del sangrado menstrual habitual.

Hipomenorrea: disminución marcada en la cantidad habitual del sangrado menstrual.

\section{Causas de las irregularidades menstruales}

I. La causa principal de que no llegue la regla es un embarazo. Si no estás embarazada puede deberse a alguno de los siguientes factores

2. Factores emocionales vinculados a estrés y angustia, los cuales alteran la producción hormonal y trastornan el proceso ovulatorio

3. Alteraciones del útero, los ovarios y el endometrio como miomas, fibromas ○ quistes

4. Pérdida o aumento excesivo de peso

5. Desórdenes alimenticios como la anorexia o bulimia

6. Problemas hormonales (principalmente de la tiroides) 


\section{Sistema Genito - Urinario y Endocrino}

7. Demasiado ejercicio (es común que atletas de alto rendimiento presenten amenorrea)

8. Problemas en los órganos de la pelvis

9. Medicamentos (algunos anticonceptivos afectan la frecuencia e intensidad de la menstruación)

10. Amamantar también es otra razón por la que puede haber ausencia de menstruación o periodos irregulares

II. Insuficiencia prematura de ovario causada por radiaciones, cirugías, quimioterapias y tratamiento contra el cáncer

12. Menopausia (alrededor de los 45 años).

\section{Exámenes de laboratorio aparato reproductor femenino}

\section{Citología vaginal}

Citología vaginal, prueba de Papanicolaou o frotis de Pap es una prueba microscópica de células tomadas por raspado de la abertura del cuello uterino. El cuello uterino es la parte más baja del útero que se abre en la parte superior de la vagina. Es una prueba de detección para cáncer de cuello uterino. Preparación para la citología vaginal. Coméntele al médico si:

a) Está tomando algún medicamento o píldoras anticonceptivas

b) Ha tenido una citología vaginal anormal

c) Podría estar embarazada.

Dentro de las 24 horas anteriores al examen, evite:
a) Las duchas vaginales
b) Tener relaciones sexuales
c) Bañarse en la tina
d) Usar tampones.

Evite programar la citología mientras tenga el período (esté menstruando), ya que esto puede afectar la precisión del examen. Si está teniendo un sangrado anormal, el médico 


\section{Sistema Genito - Urinario y Endocrino}

todavía le puede recomendar que se haga el examen.

Orine justo antes del examen

\section{Los valores normales de la citología vaginal}

Un valor normal (negativo) significa que significa que no hay células anormales presentes.

Nota: los rangos de los valores normales pueden variar ligeramente entre diferentes laboratorios. Hable con el médico acerca del significado de los resultados específicos de su examen.

Significado de los valores anormales de la citología vaginal

\section{Los resultados anormales se agrupan como sigue:}

I. CASI (células atípicas de significado indeterminado). (ASCUS ○ AGUS, por sus siglas en inglés). Estos cambios pueden deberse a infección con el VPH, pero también pueden significar que hay cambios precancerosos.

2. LIEBG (lesión intraepitelial de bajo grado) o LIEAG (lesión intraepitelial de alto grado). (LSIL o HSIL, respectivamente, por sus siglas en inglés). Esto significa que hay probabilidad de presencia de cambios precancerosos; el riesgo de cáncer es mayor si el resultado es una lesión intraepitelial de alto grado (LIEAG).

3. Carcinoma in situ (CIS): esto generalmente significa que es probable que los cambios anormales progresen hasta cáncer.

4. Células escamosas atípicas (ASC-H, por sus siglas en inglés): esto significa que se han encontrado cambios anormales y pueden ser lesión intraepitelial de alto grado (LIEAG).

5. Células glandulares atípicas (CGA): se observan cambios celulares que sugieren pre cáncer de la parte superior del canal cervicouterino o dentro del útero.

6. Cuando una citología vaginal muestra cambios anormales, se necesitan pruebas o controles adicionales. El próximo paso depende de los resultados de la citología vaginal, sus antecedentes previos de citologías y factores de riesgo que usted pueda tener para el cáncer de cuello uterino. 


\section{Sistema Genito - Urinario y Endocrino}

\section{Otros exámenes incluyen}

Biopsia: si el ginecólogo considera que tienes una lesión atípica, extraerá una pequeña muestra de la misma para analizar sus características en el laboratorio.

Dilatación y legrado: se hace un pequeño raspado de la pared del útero para diagnosticar anomalías en el endometrio.

Histerosalpingografía: se utiliza para ver el interior del útero. Se introduce una sonda de tres o cuatro milímetros de grosor que porta un sistema óptico. Con esta prueba se estudia el endometrio, la capa interna del útero. Se realiza cuando la mujer padece alteraciones del ciclo menstrual, problemas de fertilidad o para detectar malformaciones de esta cavidad.

Ecografía genital: a través de este estudio se pueden ver alteraciones en la matriz (como miomas, muy frecuentes en mujeres de 40 a 50 años), quistes en los ovarios, alteraciones en las trompas de Falopio, tumores ováricos, uterinos, alteraciones del endometrio, pólipos, o malformaciones. Es una prueba diagnóstica imprescindible ante la sospecha de patología en el útero o los ovarios.

Pruebas de virus de papiloma humano (VPH): existen dos: la Cobas Test, que simultáneamente detecta 14 tipos de VPH de alto riesgo y proporciona información específica de los tipos 16 y 18 , causantes del cáncer de cuello uterino. La citología líquida es una técnica que consiste en que, tras recoger una muestra del cuello del útero, se introduce en un botecito con líquido conservante. En el laboratorio se filtran las células y se transfieren al microscopio. Su finalidad es hacer más fácil la prueba y repetirla si fuese necesario.

Histerosalpingograma: Esta es una clase especial de máquina que permite tomar radiografías de su útero y de sus trompas de Falopio. Antes de que se tomen dichas radiografías, se le inyectará un tinte radiográfico especial formulado a base de agua o de aceite, dentro de su útero y de sus trompas de Falopio. Este tinte le permitirá a su doctor identificar más fácilmente cualquier clase de problema que pudiera haber en sus órganos a través de los rayos $\mathrm{X}$. Este dispositivo es frecuentemente utilizado para localizar 


\section{Sistema Genito - Urinario y Endocrino}

obstrucciones y otra clase de problemas.

\section{Análisis de sangre}

I. Prueba o Análisis de FSH del Día 3: La misma deberá llevarse a cabo el tercer día de su ciclo menstrual, la prueba o análisis de FSH del Día 3 se encargará de medir los niveles de hormona folículo estimulante presentes en su sistema. Altos niveles de $\mathrm{FSH}$ podrían afectar negativamente la calidad de sus óvulos.

2. Prueba de Estradiol del Día 3: La misma también deberá ser realizada durante el tercer día de su ciclo menstrual; este análisis de sangre se realizará para evaluar la cantidad de estrógeno presente en su organismo. Demasiado estrógeno podría afectar negativamente la calidad de sus óvulos.

3. Prueba o Análisis para Medir el Nivel de Progesterona en Plasma: Este análisis se encargará de determinar los niveles de progesterona en su organismo. Dado que los niveles de progesterona se incrementarán hacia el final de su ciclo; esta prueba deberá realizarse justo antes de que comience su período. Si sus niveles de progesterona fueran bajos, probablemente estarían indicando la existencia de algún problema ovulatorio.

4. Prueba de HL y de FSH: Al evaluar los niveles de la hormona luteínica y de la hormona folículo estimulante en su sistema, esta prueba puede realizarse tanto en mujeres como en hombres. Altos niveles de HL y de FSH sugerirán que usted estaría padeciendo problemas de infertilidad causados por problemas en sus ovarios (falla ovárica primaria) o -en caso de tratarse de un hombre- causados por problemas en sus testículos (falla testicular primaria). Bajos niveles de $\mathrm{HL}$ y de FSH estarían indicando que un desorden o trastorno en su glándula pituitaria o en su hipotálamo serían los causantes de sus problemas de infertilidad. 


\section{Sistema Genito - Urinario y Endocrino}

\section{GLOSARIO}

Dispareunia: o coitalgia es el coito doloroso tanto en mujeres como en hombres. Abarca desde la irritación vaginal postcoital hasta un profundo dolor. Se define como dolor o molestia antes, después o durante la unión sexual.

Fibrosis: Formación patológica de tejido fibroso en un órgano del cuerpo.

Hiperqueratosis: es un trastorno caracterizado por el engrosamiento de la capa externa de la piel, que está compuesta de queratina, una fuerte proteína protectora.

Leucoplasia: Enfermedad de las mucosas, especialmente de la bucal y la vaginal, que se caracteriza por la aparición de unas manchas blancas irregulares algo engrosadas.

Leucorrea: Secreción genital blanquecina producida por la inflamación de la membrana mucosa del útero y la vagina.

Liquen escleroso: es una afección de la piel que puede provocar comezón, sarpullido y formación de cicatrices. Por lo general, afecta las áreas genitales y anales.

Liquen simple crónico: es un trastorno cutáneo que lleva a prurito crónico y rascado. Por lo general, afecta las áreas genitales y anales.

Mucopurulento: Que contiene moco y pus.

Purulento: Que tiene pus.

Quiste: Bolsa membranosa que se forma anormalmente en los tejidos del cuerpo y que contiene una sustancia líquida o semisólida de distinta naturaleza.

\section{BIBLIOGRAFÍA SUGERIDA}

I. Khan FA, Gartley Cl, Khanam A. Canine cryptorchidism: An update. Reprod Domest Anim. 20 18;53(6): I 263-I270. doi: I0. I I I I/rda. I323 I

2. Lee PA, Houk CP. Cryptorchidism. Curr Opin Endocrinol Diabetes Obes. 20।3;20(3):2I0-2 I6. doi:I0.1097/MED.0b0I3e32835ffc7d

3. Verkauskas G, Malcius D, Dasevicius D, Hadziselimovic F. Histopathology of Unilateral Cryptorchidism. Pediatr Dev Pathol. 2019;22(I):53-58. doi:I0.I I77//0935266/8789300

4. Chung E, Gilbert B, Perera M, Roberts MJ. Premature ejaculation: A clinical review for the general physician. Aust Fam Physician. 20I5;44(10):737-743. 


\section{Sistema Genito - Urinario y Endocrino}

5. Martin C, Nolen H, Podolnick J, Wang R. Current and emerging therapies in premature ejaculation: Where we are coming from, where we are going. Int J Urol. 2017;24(I):40-50. doi: I0.1 I I I/iju. I3202

6. Cooper K, Martyn-St James M, Kaltenthaler E, Dickinson K, Cantrell A. Interventions to treat premature ejaculation: a systematic review short report. Health Technol Assess. 2015; 19(2I): I-vi. doi: I0.33 I0/hta 192 I0

7. Porter CM, Shrestha E, Peiffer LB, Sfanos KS. The microbiome in prostate inflammation and prostate cancer. Prostate Cancer Prostatic Dis. 20 I8;2I(3):345-354. doi:I0.1038/s4I39I-0I8-004I-I

8. Motrich RD, Salazar FC, Breser ML, et al. Implications of prostate inflammation on male fertility. Andrologia. 20 18;50(I I):el 3093. doi:I0.I I I I/and.I3093

9. Verze P, Cai T, Lorenzetti S. The role of the prostate in male fertility, health and disease. Nat Rev Urol. 2016;13(7):379-386. doi:I0.1038/nrurol.2016.89

10. Wang G, Zhao D, Spring DJ, DePinho RA. Genetics and biology of prostate cancer. Genes Dev. 2018;32(I7-18): I I05-I|40. doi:I0.II0I/gad.315739.II8

II. Murillo-Garzón V, Kypta R. WNT signalling in prostate cancer. Nat Rev Urol. 2017; |4(I I):683-696. doi:10.1038/nrurol.2017.144

12. Rebbeck TR. Prostate Cancer Genetics: Variation by Race, Ethnicity, and Geography. Semin Radiat Oncol. 2017;27(1):3-10. doi:I0.1016/j.semradonc.2016.08.002

13. Khera M. Testosterone Therapies. Urol Clin North Am. 2016;43(2):185-193. doi:10.1016/j.ucl.2016.01.004

14. Goldman AL, Bhasin S, Wu FCW, Krishna M, Matsumoto AM, Jasuja R. A Reappraisal of Testosterone's Binding in Circulation: Physiological and Clinical Implications. Endocr Rev. 20 17;38(4):302-324. doi: I0.I210/er.2017-00025

15. Stárka L. Testosteron a mortalita [Testosterone and mortality]. Vnitr Lek. 2016;62(9 Suppl 3):I27-130.

16. Abduljabbar HS, Bukhari YA, Al Hachim EG, et al. Review of 244 cases of ovarian cysts. Saudi Med I. 20 I5;36(7):834-838. doi:I0.I5537/smj.20I5.7.I I690

17. Trinh TW, Kennedy AM. Fetal ovarian cysts: review of imaging spectrum, differential diagnosis, management, and outcome. Radiographics. 20I5;35(2):62I635. doi: I0.1I48/rg.352140073

18. Odle TG. Precision Medicine in Breast Cancer. Radiol Technol. 20I7;88(4):40IM42 IM.

19. Anastasiadi Z, Lianos GD, Ignatiadou E, Harissis HV, Mitsis M. Breast cancer in young women: an overview. Updates Surg. 2017;69(3):313-317. doi:I0.1007/s I3304-0 I7-0424-I

20. Kolak A, Kamińska M, Sygit K, et al. Primary and secondary prevention of breast cancer. Ann Agric Environ Med. 2017;24(4):549-553. doi:I0.26444/aaem/75943

21. Henley SJ, Miller JW, Dowling NF, Benard VB, Richardson LC. Uterine Cancer Incidence and Mortality - United States, 1999-2016. MMWR Morb Mortal Wkly Rep. 20 I8;67(48): I333-I338. Published 2018 Dec 7. doi:I0.I5585/mmwr.mm6748a I 


\section{Sistema Genito - Urinario y Endocrino}

22. Felix AS, Brinton LA. Cancer Progress and Priorities: Uterine Cancer. Cancer Epidemiol Biomarkers Prev. 20 I 8;27(9):985-994. doi:I 0. I I 58/I 055-9965.EPI- I 8-0264

23. Sundar S, Balega I, Crosbie E, et al. BGCS uterine cancer guidelines: Recommendations for practice. Eur J Obstet Gynecol Reprod Biol. 2017;213:71-97. doi:10.1016/j.ejogrb.2017.04.015

24. Webb PM, Jordan SI. Epidemiology of epithelial ovarian cancer. Best Pract Res Clin Obstet Gynaecol. 2017;41:3-14. doi:10.1016/j.bpobgyn.2016.08.006

25. Ottevanger PB. Ovarian cancer stem cells more questions than answers. Semin Cancer Biol. 20I7;44:67-7I. doi:I0.1016/j.semcancer.2017.04.009

26. Tsikouras $P$, Zervoudis $S$, Manav B, et al. Cervical cancer: screening, diagnosis and staging. I BUON. 2016;2 I (2):320-325.

27. Wardak S. Human Papillomavirus (HPV) and cervical cancer. Med Dosw Mikrobiol. 2016;68(I):73-84.

28. Marquina G, Manzano A, Casado A. Targeted Agents in Cervical Cancer: Beyond Bevacizumab. Curr Oncol Rep. 2018;20(5):40. Published 2018 Apr 2. doi:|0.1007/s||9|2-0|8-0680-3

29. Böcher S, Helmig RB, Arpi M, Bjerrum L. Ugeskr Laeger. 20 I8; I80(3):V03 I 70229.

30. Forrester SD, Towell TL. Feline idiopathic cystitis. Vet Clin North Am Small Anim Pract. 20I5;45(4):783-806. doi:I0.1016/j.cvsm.2015.02.007

3I. Zaitsev AV, Kasyan GR, Spivak LG. Urologiia. 2017;(I Suppl I):34-44. doi: 10.18565/urol.2017.I-supplement.34-44

32. Damiani L, Quadros M, Posser V, Minotto R, Boff AL. Zoon vulvitis. An Bras Dermatol. 2017;92(5 Suppl I):I66-I68. doi:I0.1590/abd I806-484I.20I75622

33. Kitaya K, Takeuchi T, Mizuta S, Matsubayashi H, Ishikawa T. Endometritis: new time, new concepts. Fertil Steril. 2018;110(3):344-350. doi:10.1016/j.fertnstert.2018.04.012

34. Mehedintu C, Plotogea $M N$, lonescu S, Antonovici M. Endometriosis still a challenge. I Med Life. 2014;7(3):349-357.

35. Falcone T, Flyckt R. Clinical Management of Endometriosis. Obstet Gynecol. 2018; I 3 | (3):557-57I. doi:I0.I097/AOG.0000000000002469

36. Meier RK. Polycystic Ovary Syndrome. Nurs Clin North Am. 2018;53(3):407-420. doi: 10.1016/j.cnur.2018.04.008

37. Bednarska S, Siejka A. The pathogenesis and treatment of polycystic ovary syndrome: What's new?. Adv Clin Exp Med. 2017;26(2):359-367. doi: $10.17219 /$ acem/59380

38. Vázquez F, Fernández-Blázquez A, García B. Vaginosis. Vaginal microbiota. Vaginosis. Microbiota vaginal. Enferm Infecc Microbiol Clin. 2019;37(9):592-60I. doi:I0.1016/j.eimc.2018.1I.009 
Sistema Genito - Urinario y Endocrino

Capítulo III

Hormonas sexuales, comportamiento sexual y zonas erógenas 


\section{Sistema Genito - Urinario y Endocrino}

\section{CAPITULO III}

\section{HORMONAS SEXUALES}

Las hormonas son sustancias segregadas por las glándulas de nuestro cuerpo y se encargan de regular diferentes funciones en nosotros, dentro de estas, las funciones sexuales. Las hormonas sexuales son fabricadas y segregadas por las glándulas sexuales, es decir, por los ovarios en la mujer y por los testículos en el hombre. Desde que entramos a la pubertad, las hormonas sexuales despiertan y es entonces cuando producen una serie de cambios a nivel físico y emocional en nosotros.

La liberación de hormonas está regulada por dos partes del cerebro: Hipófisis e Hipotálamo. Ellos detectan el exceso o falta de hormonas y es así como provocan la detención o liberación hormonal. Los niveles de hormonas sexuales varían de una persona a otra, también estos niveles dependen del momento de la vida en el que la persona se encuentre. Las hormonas sexuales son las que marcan muchas de las diferentes características entre hombres y mujeres, y sin lugar a duda, son las que mandan nuestra libido.

\section{Hormonas sexuales femeninas}

Las hormonas sexuales femeninas que produce el ovario son los estrógenos y la progesterona. La función principal de las hormonas sexuales femeninas consiste en la preparación del aparato reproductor para recibir la esperma masculina y mantener las condiciones adecuadas para la implantación del óvulo fecundado.

Estas hormonas se segregan de manera cíclica cada 28 días durante la edad fértil de la mujer, dando lugar a lo que llamamos "ciclo menstrual”. Luego, alrededor de los 50 años, la función ovárica se reduce poco a poco hasta detenerse por completo, cesa la producción hormonal y es entonces cuando la mujer entra a la etapa de su vida conocida como “menopausia”. El deseo sexual femenino también se asocia a la segregación de hormonas durante el ciclo menstrual. También las hormonas femeninas trabajan cuando:

I. Las chicas experimentan cambios al entrar a la pubertad.

2. Se estimula el crecimiento de la vagina, los ovarios y trompas de Falopio. 


\section{Sistema Genito - Urinario y Endocrino}

3. Se desarrollan las mamas.

4. Hay un cambio en la apariencia física al entrar a la adolescencia por la nueva distribución de la grasa corporal.

5. Crecimiento rápido de estatura en la pubertad.

6. Cuando menstruas.

7. Al lubricar durante el sexo

8. Los ovarios también producen testosterona en pequeñas cantidades que los estrógenos son capaces de contrarrestar hasta que llega la menopausia.

\section{Hormonas sexuales masculinas}

El testículo es el encargado de producir andrógenos u hormonas sexuales masculinas. La testosterona es la principal de ellas. La testosterona se produce en unas células especializadas del testículo llamadas células de Leydig. La producción de testosterona en el hombre se reduce también con el envejecimiento, pero su reducción es de forma menos marcada y brusca que como sucede en las mujeres con los estrógenos.

Los andrógenos cumplen con gran cantidad de funciones en los varones e indiscutiblemente, son las que marcan su diferencia con las mujeres. Dentro de estas funciones podemos mencionar:

I. Aumento del tamaño del pene y escroto.

2. Aparición de vello púbico.

3. Crecimiento en estatura.

4. Cambio en el tono de voz al estimular el crecimiento de la laringe.

5. Cambios en la textura de la piel, la hacen más gruesa y grasosa.

6. Aparición de vello corporal.

7. En conjunto con otra sustancia llamada "gonadotropina" maduran la esperma.

8. Ayudan a la síntesis de proteínas y desarrollo muscular, por ello es que los hombres tienen más masa muscular que las mujeres.

9. Los andrógenos también trabajan deteniendo el crecimiento de los huesos largos luego del "estirón puberal" (crecimiento rápido en altura que se da en la pubertad).

10. Todas las hormonas sexuales se sintetizan a partir del colesterol 


\section{Sistema Genito - Urinario y Endocrino}

\section{El comportamiento sexual}

El comportamiento sexual humano reagrupa todos los mecanismos del comportamiento reproductor humano y todos los comportamientos eróticos. En resumen, el comportamiento sexual humano es, a la vez, la necesidad de dar a luz para la supervivencia de la especie y de la búsqueda del placer. Los mecanismos que intervienen son numerosos y, a menudo, muy complejos. Ellos pueden ser físicos (por ejemplo, la erección), hormonales pero también mentales. Los fantasmas, la educación y las normas sexuales admitidas por la sociedad también son factores a tener en cuenta. La conducta sexual se refiere a todo tipo de práctica sexual que una persona puede realizar consigo misma, con otra persona, bien sea homosexual, heterosexual o bisexual, o incluso en grupo. El beso, las caricias, el coito vaginal o anal, la masturbación, el sexo bucal, las fantasías o la combinación de varios de ellos, son algunas de las conductas sexuales más comunes.

\section{Respuesta sexual}

Es un sentido puramente biológico, las personas tienen que involucrarse en las relaciones sexuales para procrear. El incentivo consiste en un deseo innato de sexo, o deseo sexual, unido a la respuesta sexual: los sentimientos placenteros y estimulantes experimentados durante el contacto erótico. En realidad, la mayoría de actos sexuales no tiene una finalidad procreadora, sino que se realizan por motivos de placer, por razones emocionales o sociales, o para establecer un vínculo con la pareja.

La respuesta sexual es la secuencia de cambios fisiológicos o psicológicos que se produce durante e inminentemente después del acto sexual, y que esta medida por el sistema nervioso. Esta respuesta discurre por varias frases, pero en esencia es la misma en hombres y mujeres, aunque más adelante se describen diferencias específicas. En una relación sexual, el contacto acostumbra a terminar cuando el pene se introduce en la vagina hasta que se produce una eyaculación, y se deposita el semen en la porción superior de la vagina y el cuello uterino. Sin embargo, la respuesta sexual del cuerpo 


\section{Sistema Genito - Urinario y Endocrino}

puede producirse tanto si la pareja tiene relaciones con penetración como sin ella, o tanto si es heterosexual como homosexual.

\section{Frases de la respuesta sexual}

Cuando las dos personas están sexualmente motivadas, experimentando deseos y sintiéndose mutuamente atraídas en el plano sexual, sus cuerpos, si están lo bastante estimulados, responderán sexualmente. La respuesta sexual sigue cuatro etapas o fases: excitación, meseta, orgasmo y resolución. En la práctica, estas fases pueden ser imposibles de distinguir, porque se suceden sin interrupción. La duración de cada fase y lo que sucede en concreto durante cada una de ellas varía de una persona a otra, y de un acto sexual a otro.

\section{Excitación}

Durante la excitación, el cuerpo se $<<$ conecta $>>$ sexualmente. Los impulsos nerviosos desencadenan un cierto número de acciones reflejas, estimulados por el tacto y la presión, y detectados por sensores localizados en varios puntos del cuerpo, especialmente el clítoris y otras partes de la vulva, el glande y otras partes del pene y los pezones. Las áreas sexualmente sensibles del cuerpo se conocen como zonas erógenas. Los pensamientos y recuerdos sexuales, así como la visión, sonido olor de la pareja también desencadenan la excitación.

Se estimulan los músculos lisos de las paredes de los vasos sanguíneos genitales para que se relajen, de manera que aumenta el riego sanguíneo. Los órganos genitales, como el clítoris, los labios y el pene, crecen a medida que se llenan de sangre. Se segregan líquidos lubricantes, en particular en la vagina y la vulva de la mujer, y en las glándulas bulbouretrales del glande del hombre, para que la relación sexual sea cómoda y agradable, reduciendo la fricción.

La excitación sexual no se centra exclusivamente en los genitales. El ritmo cardiaco, el respiratorio y la presión sanguínea aumentan, así como la tensión de la musculatura esquelética, a la vez que algunas zonas de la piel pueden enrojecer. Además de percibir 


\section{Sistema Genito - Urinario y Endocrino}

sensaciones placenteras, el cerebro también se encuentra en el acto sexual y en la pareja, y reduce el nivel normal de atención sobre todo lo demás.

\section{Meseta}

Durante la fase de meseta, que puede durar unos segundos, unos minutos o unas horas, el nivel de excitación sexual generado durante la excitación se mantiene hasta la etapa siguiente, el orgasmo, que marca el clímax de la secuencia de respuesta.

\section{Orgasmo}

La culminación del estímulo sexual en ambos sexos viene marcada por un orgasmo, una sensación característica de intenso placer, acompañadas de ondas de contracción muscular y relajación de la tensión. Los impulsos del hipotálamo y del cerebro viajan hasta la parte baja de la medula espinal cuando el estímulo sexual alcanza su punto máximo. Las fibras de la función simpática del sistema nervioso autónomo transportan estos impulsos nerviosos hasta los genitales, lo que provoca la contracción rítmica de la musculatura lisa entre 3 y 15 veces cada 0,8 segundos, combinada con sensaciones de placer. Al mismo tiempo, las neuronas motoras somáticas de la medula espinal inervan los músculos esqueléticos del periné, los músculos de la abertura inferior de la pelvis, para que se contraigan, exprimiendo más los genitales y el ano. En los hombres, el orgasmo va acompañado de una eyaculación.

\section{Resolución}

Después del orgasmo, los órganos genitales inflamados recuperan su tamaño normal, con más rapidez en el hombre que en la mujer, volviendo asimismo el ritmo respiratorio y el cardiaco a valores normales y relajándose también los músculos esqueléticos tensos. La mayoría de hombres y mujer experimentan una sensación de relajación y reducción de la tensión llamada resolución, la fase final de la respuesta sexual.

Cuando están en esta fase, los hombres no experimentan excitación durante un tiempo, minutos, horas o días, dependiendo de su estado de ánimo y su edad, mientras que las mujeres aún son capaces de experimentar otros orgasmos. 


\section{Sistema Genito - Urinario y Endocrino}

Durante la fase de meseta, el tercio inferior de la vagina se estrecha, aumentando la presión sobre el pene durante la relación sexual. Al mismo tiempo, el útero se eleva y los dos tercios superiores de la vagina se expanden y se alargan.

Puede producirse un enrojecimiento o rubor sexual en la piel, sobre todo, el pecho.

Durante el orgasmo, los músculos vaginales y otros se contraen rítmicamente. Cuando se inicia la resolución, el útero desciende $y$, al hacerlo empuja el cuello contra la acumulación de semen depositado en el extremo superior de la vagina dilatada, si se ha producido una eyaculación.

\section{Respuesta sexual masculina}

En el hombre, la erección es el acontecimiento principal de las fases de excitación y meseta, y la eyaculación, el de la fase de orgasmo. Durante la excitación el pene experimenta una erección y los testículos se hinchan a la vez el escroto tira de ellos hacia arriba. En la fase de meseta, el glande continúa su expansión, haciendo que la forma sea más afilada. Tras la eyaculación y el orgasmo, no se puede producir otra excitación, hasta transcurrido un periodo de descanso.

\section{Erección}

La erección es un acto reflejo controlado por la porción parasimpática del sistema nervioso. Normalmente, cuando el pene esta flácido, las arterias y arteriolas que lo riegan permanecen relativamente comprimidas. Durante la excitación sexual el reflejo de la erección se dispara y los impulsos nerviosos se estimulan, para que se relaje la fibra muscular lisa de las paredes de las arterias y arteriolas penianas, de manera que los vasos sanguíneos se dilatan y el volumen de sangre que vierten hacia el pene, aumenta.

Esta cantidad adicional de sangre llena los espacios que hay en los tres cilindros alargados de tejido poroso, que constituyen el cuerpo del pene, haciendo que su eje y el glande se dilaten y se alarguen como lo hace un globo cuando se llena de aire. A medida que los tejidos esponjosos se expanden, comprimen las venas normalmente drenan la sangre de salida del pene, restringiendo así su flujo, y favoreciendo aún más el proceso de erección. 


\section{Sistema Genito - Urinario y Endocrino}

Las glándulas bulbouretrales también se estimulan para segregar su líquido, que lubrica la uretra y el glande. Éstas suelen incitar la erección, como también la excitación en general, la estimulación directa de los sensores del tacto y la presión del pene, especialmente, en el glande. Esto hace que la medula espinal transmita mensajes desde el centro de erección a los vasos sanguíneos del pene. Alternativamente o al mismo tiempo, el cerebro, en respuesta a diversos estímulos internos, manda mensajes al centro de erección de la medula espinal. Además, los hombres pueden despertarse con una erección, bien generada por algún estimulo experimentado durante la fase de sueño REM, o por la presión provocada por la vejiga llena. Asimismo, algunos estímulos no sexuales posibilitan a veces erecciones no deseadas, sobre todo en adolescentes. Los bebes en ocasiones también las experimentan.

\section{Eyaculación}

Durante la eyaculación, el semen se expulsa con fuerza por el pene y si la relación sexual no está protegida, llega hasta la vagina y el cuello uterino. Igual que la erección, la eyaculación es una acción refleja controlada por el sistema nervioso autónomo. Las fibras simpáticas que trasmiten los impulsos hacia el sistema de conductos y el pene surgen del centro eyaculador en la porción inferior de la medula espinal. La eyaculación se inicia cuando la estimulación que provoca mantiene la excitación sexual alcanza un nivel crítico. El proceso, que apenas dura unos segundos, tiene dos fases: emisión y eyaculación.

\section{ZONAS EROGENAS Y RELACIONES SEXUALES}

Habitualmente la culminación de la actividad sexual, el coito, permite la procreación. En las parejas heterosexuales, cuando ambos miembros estas suficientemente excitados, él en erección, y ella excitada y lubricada, el hombre introduce su pene en la vagina. Una vez dentro, lo mueve hacia adelante y hacia atrás. Este movimiento estimula al pene lo suficiente como para provocar la eyaculación y el orgasmo en el hombre. En la mujer, la relación sexual puede que no llegue a producir un orgasmo, porque la estructura reproductora más sensible, el clítoris, no se estimula directamente. Después de la 


\section{Sistema Genito - Urinario y Endocrino}

eyaculación los espermatozoides se mueven rápidamente, y en el plazo de 90 segundos están nadando en el moco que llena la entrada del útero. De los millones de espermatozoides eyaculados, solamente unos pocos cientos penetran en el moco cervical, y se embarcan en un largo viaje a través del útero y las trompas uterinas.

\section{Zonas erógenas}

Las zonas erógenas son todas aquellas partes del cuerpo humano (no exclusivamente los órganos genitales) que presentan una mayor sensibilidad y cuyo estímulo tiene como finalidad y resultado activar sexualmente a una persona. Distintas zonas del cuerpo pueden resultar más o menos erógenas en cada persona, es decir, hay en este sentido, grandes diferencias individuales

\section{Anatomía}

Se puede clasificar de dos maneras: "no específica" y "mental".

No específica: La piel se compone de infinidad de terminaciones nerviosas y folículos de pelo, las áreas más proclives a ser clasificadas como erógenas están situadas a los lados del cuello y su parte posterior, en las axilas y ambos lados del tórax. Acariciar la zona y el nerviosismo previo cuando se produce el acercamiento para realizarla son síntomas de que hay respuesta sensual.

Mental: Con la mente se puede llegar a sitios insospechados siempre que se acompañe de una buena imaginación trayendo imágenes eróticas, y un gran poder de concentración.

\section{Zonas erógenas genitales masculinas}

\section{Pene}

El pene está compuesto de terminaciones nerviosas en todo lo largo y ancho pero particularmente en la zona superior, su simple caricia suele ser por norma motivo de excitación.

\section{Glande y prepucio}

El prepucio al igual que el glande está repleto de terminaciones nerviosas que resguardan el glande, o cabeza del pene, del exterior haciéndole conservar toda su sensibilidad. En muchas culturas, ya sea por tradición, por higiene o por religión, el prepucio es sesgado 


\section{Sistema Genito - Urinario y Endocrino}

justo al nacer el niño o a los pocos años de vida, lo que se conoce como circuncisión. El prepucio es la cobertura de piel fina que poseen los hombres que no están circuncidados. No es muy considerado a la hora de mantener una relación sexual pero si se manipula con prudencia se puede encontrar una mina de placer masculina.

\section{Testículo}

Los testículos también son una importante zona erógena de los hombres, incluso es el lugar donde se puede controlar una eyaculación. Durante el coito, los testículos se van contrayendo hasta un cierto punto donde se concentran los espermatozoides y luego se sueltan con gran fuerza. El sexo oral es un importante medio si se quiere estimular especialmente los testículos.

\section{Punto P}

El punto $\mathrm{P}$ o punto prostático se localiza detrás de los testículos, es una zona responsable de excitación y placer durante el acto sexual. Se localiza en la próstata. La próstata es un órgano glandular del aparato genitourinario masculino ubicada enfrente del recto, debajo y a la salida de la vejiga urinaria. El punto $P$ es un contribuyente clave en el orgasmo masculino.

La próstata se encarga de producir y segregar líquido prostático durante la eyaculación, el cual nutre y protege el esperma durante el acto sexual. La próstata se localiza adyacente al recto, puede ser estimulada manualmente tanto en forma interna como externa. Se puede estimular externamente presionando la zona del periné (zona que va desde el ano hasta los testículos), por cuanto esta zona cuenta con una gran cantidad de terminaciones nerviosa.

\section{BIBLIOGRAFÍA SUGERIDA}

I. Ma WL, Wang X, Mao JF, et al. Zhonghua Yi Xue Za Zhi. 2019;99(24):1875-I880. doi:I0.3760/cma.j.issn.0376-249I.2019.24.008 


\section{Sistema Genito - Urinario y Endocrino}

2. Roved J, Westerdahl H, Hasselquist D. Sex differences in immune responses: Hormonal effects, antagonistic selection, and evolutionary consequences. Horm Behav. 2017;88:95-105. doi:10.1016/i.yhbeh.2016.11.017

3. Baldaçara RP, Silva I. Association between asthma and female sex hormones. Sao Paulo Med I. 2017;135(I):4-I4. doi:10.1590/I516-3180.2016.01।827016

4. Sims ST, Heather AK. Myths and Methodologies: Reducing scientific design ambiguity in studies comparing sexes and/or menstrual cycle phases. Exp Physiol. 2018;|03(I0):|309-1317. doi:I0.1 I I3/EP086797

5. Alexander M, Marson L. Orgasm and SCl: what do we know?. Spinal Cord. 2018;56(6):538-547. doi:10.1038/s4I393-017-0020-8

6. Pastor Z. Female ejaculation orgasm vs. coital incontinence: a systematic review.J Sex Med. 2013;10(7):I682-I69I. doi:I0.IIII/jsm.I2I66

7. Hsu KI, Rosenthal AM, Miller DI, Bailey IM. Sexual Arousal Patterns of Autogynephilic Male Cross-Dressers. Arch Sex Behav. 2017;46(I):247-253. doi: I0.1007/s 10508-016-0826-z

8. Calabrò RS, Cacciola A, Bruschetta D, et al. Neuroanatomy and function of human sexual behavior: A neglected or unknown issue?. Brain Behav. 2019;9(I2):e01389. doi:10.1002/brb3.1389 
Sistema Genito - Urinario y Endocrino

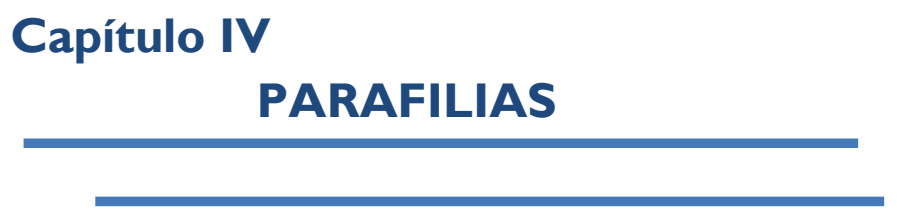




\section{Sistema Genito - Urinario y Endocrino}

\section{CAPITULO IV}

\section{PARAFILIA}

\section{Parafilia}

Una parafilia es un patrón de comportamiento sexual en el que la fuente predominante de placer se encuentra en objetos, situaciones, actividades o individuos atípicos. No existe un consenso para establecer un límite preciso entre el interés sexual inusual y la parafilia. Incluso existe debate sobre si alguna de las consideradas parafilias debería figurar en los manuales de diagnóstico o no.

El número y taxonomía de las parafilias también es controvertido; algunas fuentes listan hasta 549 tipos de parafilias. El DSM-5 tiene especificados ocho desórdenes parafilicos. Se han propuesto varias subclasificaciones de las parafilias pero algunos argumentan que un enfoque psicológico completo podría reflejar mejor la evidencia.

\section{Diagnóstico diferencial}

Se puede confundir con ciertas enfermedades mentales como:

-Esquizofrenia

-Trastorno obsesivo compulsivo

-Las fantasías, los comportamientos o los objetos son considerados parafílicos sólo si provocan malestar o alteraciones clínicamente significativas.

Terapia sexual: Dirigida a facilitar la excitación y orgasmo ante el estímulo no parafílico, es una ayuda adjunta al tratamiento con pacientes que presentan disfunciones sexuales específicas cuando se inician acercamientos no parafílicos con parejas.

Terapia conductual: Es utilizada para reducir la conducta parafílica por medio de un alto nivel de agresión al paciente mediante el uso de choques eléctricos en el momento de exposición al estímulo parafílico aprendido.

\section{Diagnóstico definitivo}




\section{Sistema Genito - Urinario y Endocrino}

Resulta difícil realizar este diagnóstico, ya que determinadas fantasías o conductas parafílicas pueden hallarse incorporadas a unas relaciones sexuales normales, satisfactorias y entre personas que las aceptan. En otros, no obstante, existe una violación de la libertad de la otra persona.

Para diagnosticar una parafilia, el DSM-III-R requiere que ésta constituya una evidente perturbación para el individuo y que se presente, como mínimo, durante 6 meses. Se desconoce la etiología de estos trastornos así como su prevalencia.

Rara vez se diagnostican en la clínica y la mayoría de los parafílicos se descubren a raíz de conflictos con la justicia. Tienden a cronificarse y sus inicios se sitúan en la infancia, la adolescencia o principio de la edad adulta.

También es recomendado usar medicamento como antipsicóticos o antidepresivos y antiandrógenos.

Por tanto, la actividad sexual de los humanos presenta múltiples vertientes: la reproducción, la dimensión afectiva, el erotismo, la pornografía, la moralidad asociada al sexo y un amplio abanico de perspectivas. De una manera algo simplificada podríamos decir que el coito y los preliminares sexuales son la principal fuente de placer. Sin embargo, el placer sexual va mucho más allá, pues puede producirse de muchas maneras. Así, todas aquellas inclinaciones sexuales y eróticas distintas a lo convencional y por las que se puede obtener placer son conocidas como parafilias.

En cuanto a la palabra parafilia, proviene del griego para (al margen de) y filia, que significa amor.

\section{Asfixia erótica}

Consiste en impedir la respiración de la pareja o la propia, ya sea mediante la obstrucción de las vías respiratorias cubriendo la cabeza con elementos plásticos o de látex o recurriendo a la semiestrangulación. Se trata de una práctica sexual peligrosa que ha llegado a ser causa de muerte. Cuando lo practica una persona sola se denomina asfixia autoerótica. El término «autoasfixia erótica» fue acuñado en 1991 en un estudio en una revista científica estadounidense. 


\section{Sistema Genito - Urinario y Endocrino}

Es considerado una parafilia (práctica sexual no ortodoxa). La Asociación Estadounidense de Psiquiatría considera que la privación de oxígeno con el objetivo de aumentar la intensidad del orgasmo se clasifica como hipoxifilia. En la comunidad BDSM, las prácticas de esta naturaleza pueden ser denominadas breathplay (juego con la respiración) o edgeplay (juego de borde, o juego riesgoso), y generalmente incluyen un socio participante. Al igual que otras prácticas sexuales de riesgo, el compañero amplía los límites de lo seguro, sensato y consensuado. El control de las situaciones que afectan a la respiración se puede evaluar, usando algún tipo de señal convenida para avisar a la otra persona del peligro. Esta práctica se realiza casi siempre junto a otras actividades fetichistas.

\section{Necrofilia}

La necrofilia es una parafilia caracterizada por atracción sexual hacia los cadáveres tanto en humanos como en animales. La palabra proviene del griego vekpós (nekros«cadáver»

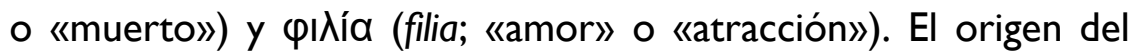
término parece ser la obra escrita en 1886 por el psiquiatra

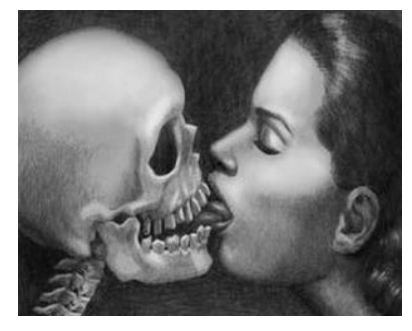
alemán Krafft-Ebing Psychopathia Sexualis(«psicopatía del sexo»)

\section{Fetichismo sexual}

Fetichismo (del latín, facticius, 'artificial', y del portugués feitiço, 'magia', 'manía'; del francés fétiche) es una parafilia que consiste en la excitación erótica o la facilitación y el logro del orgasmo a través de un objeto fetiche, como una prenda de vestir o la termodinámica. El fetichismo sexual se considera una práctica inofensiva, salvo en el caso de que provoque malestar clínicamente significativo o problemas a la persona que lo padece o a terceros, pudiendo en este caso llegar a considerarse un trastorno patológico propiamente dicho.

EI DSM IV lo clasifica como enfermedad siempre y cuando sea una conducta recurrente durante al menos seis meses, necesaria para la excitación sexual y que afecte la vida social 


\section{Sistema Genito - Urinario y Endocrino}

o laboral del sujeto. En el caso de que ésta no afecte la vida social o laboral del paciente, se considera simplemente como una manifestación de su sexualidad.

\section{Pedofilia}

Desde un punto de vista médico, la paidofilia o pedofilia es una parafilia que consiste en la excitación o el placer sexual que se obtiene, principalmente a través de actividades o fantasías sexuales con niños de, generalmente, entre 8 y 12 años. La paidofilia $\circ$ la pedofilia es un trastorno psiquiátrico en el que un adulto $\circ$ un adolescente mayor experimenta una atracción sexual primaria o exclusiva a los niños prepúberes. Aunque las niñas suelen comenzar el proceso de la pubertad a los 10 u II años, y los niños a los II o I 2 años, los criterios para la pedofilia se amplían al punto de corte para la prepubescencia que vendría rodeando a la edad de 13 años. Una persona que es diagnosticada con pedofilia debe tener por lo menos 16 años de edad y, por lo menos, 5 o 6 años más que el niño prepúber, para que la atracción sea diagnosticada como pedofilia.

La pedofilia es un rasgo multifactorial en la personalidad del que la padece, y se compone de aspectos mentales, institucionales, de actividad, de educación sexual, de violencia, de control de las pulsiones, etc. En este sentido, se suelen distinguir dos tipos de pedofilia: una primaria o esencial, muy arraigada en el sujeto, y otra secundaria (u otras), que aparecería motivada por factores circunstanciales.

Las conductas pedófilas son muy heterogéneas, desde casos inofensivos, hasta aquellos en que alcanzan niveles que entran dentro de lo criminal. A la actividad sexual de un pedófilo con un menor pre pubescente o menos de 12 años se la conoce con el nombre de abuso sexual infantil o pederastia (palabra que, etimológicamente, significa lo mismo que pedofilia).

En el uso popular, la palabra pedofilia se suele aplicar a cualquier interés sexual en los niños o el acto de abuso sexual infantil. Este uso confunde la atracción sexual hacia los niños pre púbere con el acto de abuso sexual infantil, y no distingue entre la atracción a pre- púberes y púberes o post-púberes menores de edad. Los investigadores recomiendan 


\section{Sistema Genito - Urinario y Endocrino}

que se eviten estos usos imprecisos, ya que si bien las personas que cometen abuso sexual infantil a veces presentan el trastorno sexual de niños, los infractores de abuso no son pedófilos a menos que tengan un interés sexual primaria o exclusiva en los niños pre púberes, y la literatura indica la existencia de pedófilos que no abusan de los niños.

\section{Masoquismo}

El masoquismo sexual es la participación intencional en una actividad en la cual el sujeto es humillado, golpeado y atado o es objeto de algún otro tipo de abuso para experimentar excitación sexual. El trastorno de masoquismo sexual es el masoquismo sexual que provoca malestar significativo o significativamente perjudica el funcionamiento de la persona.

El masoquismo sexual es una forma de parafilia pero la mayoría de las personas que tienen intereses masoquistas no cumplen los criterios clínicos de un trastorno parafílico, que requieren que el comportamiento, las fantasías o los impulsos intensos de la persona provoquen malestar o deterioro clínicamente significativos. La afección también debe haber estado presente durante 6 meses.

Las fantasías y la conducta sexual sadomasoquistas entre adultos que consienten su práctica es muy frecuente. La actividad masoquista tiende a ser ritual y duradera. En la mayoría de los casos, la práctica en la humillación y los golpes simplemente se representa en fantasías, sabiendo los participantes que es un juego y evitando cuidadosamente una humillación o daños reales. Sin embargo, la intensidad de la actividad aumenta con el tiempo en algunos masoquistas y pueden provocarse lesiones graves o la muerte. Las actividades de los masoquistas pueden ser la manera preferida o exclusiva de producir la excitación sexual. Las personas pueden concretar sus fantasías masoquistas en sí mismos, por ejemplo:

-Atándose ellos mismos

-Pinchando su propia piel

-Aplicándose descargas eléctricas 


\section{Sistema Genito - Urinario y Endocrino}

-Quemándose a sí mismos.

Como con todas las parafilias, el diagnóstico de un trastorno se justifica solamente si hay malestar clínicamente significativo o deterioro funcional. El tratamiento de este trastorno no suele ser eficaz.

\section{Sadismo}

El sadismo sexual comporta actos en los que la persona experimenta excitación sexual al infligir sufrimiento físico o psicológico a otra persona. El trastorno de sadismo sexual es el masoquismo sexual que provoca malestar significativo, afecta sustancialmente al funcionamiento diario del que lo padece o daña a otra persona.

El sadismo sexual es una forma de parafilia. La mayoría de las personas con tendencias sádicas no sufren un trastorno de sadismo sexual. En relaciones sexuales sanas es frecuente que exista un cierto juego de sadismo y masoquismo y las parejas compatibles a menudo lo busca uno en el otro. Por ejemplo, el uso de pañuelos de seda para simular ataduras y las palmadas suaves durante la actividad sexual son prácticas comunes entre parejas que lo consienten, y no son considerados prácticas sadomasoquistas.

La mayoría de los sádicos interaccionan con una pareja que consiente (que puede tener masoquismo sexual). En estas relaciones, la humillación y las palizas son simples actuaciones, donde los participantes saben que es un juego y evitan cuidadosamente la humillación real o las lesiones. Las fantasías de control y dominio total son a menudo importantes, y los sádicos pueden atar y amordazar a su pareja sexual de maneras muy sofisticadas. Por el contrario, el trastorno de sadismo sexual implica una o más de una de las características siguientes:

-La persona está angustiada por su comportamiento o es incapaz de funcionar a causa de este

-Lleva sus actos hasta el extremo, y en algunas ocasiones provoca graves daños corporales o psicológicos o incluso la muerte -Los actos involucran a compañeros no consentidores. 


\section{Sistema Genito - Urinario y Endocrino}

Cuando se practica con compañeros no consentidores, el sadismo sexual se considera delito y es probable que continúe hasta que el sádico sea aprehendido.

El sadismo sexual no es sinónimo de violación, sino que se trata de una compleja mezcla de sexo y poder sobre la víctima. El sadismo sexual se diagnostica en menos de $10 \%$ de los violadores, pero entre el 37 y el 75\% de las personas que han cometido homicidios por motivos sexuales. El sadismo sexual es particularmente peligroso en personas que también sufren trastorno de personalidad antisocial. El tratamiento del trastorno sádico sexual suele ser ineficaz.

\section{BIBLIOGRAFÍA SUGERIDA}

1. Lawrence AA. Autogynephilia: an underappreciated paraphilia. Adv Psychosom Med. 2011;31:135-148. doi:10.1159/000328921

2. Witztum E, Rösler A. Paraphilia. Isr J Psychiatry Relat Sci. 2012;49(4):246247.

3. Lehmann RJB, Schmidt AF, Jahnke S. Stigmatization of Paraphilias and Psychological Conditions Linked to Sexual Offending [published online ahead of print, 2020 Apr 30]. J Sex Res. 2020;1-10. doi:10.1080/00224499.2020.1754748

4. Doshi SM, Zanzrukiya K, Kumar L. Paraphilic infantilism, diaperism and pedophilia: A review. J Forensic Leg Med. 2018;56:12-15. doi:10.1016/j.jflm.2018.02.026

5. Fazio RL. Toward a Neurodevelopmental Understanding of Pedophilia. $J$ Sex Med. 2018;15(9):1205-1207. doi:10.1016/j.jsxm.2018.04.631

6. Bruce SL, Ching THW, Williams MT. Pedophilia-Themed ObsessiveCompulsive Disorder: Assessment, Differential Diagnosis, and Treatment with Exposure and Response Prevention. Arch Sex Behav. 2018;47(2):389402. doi:10.1007/s10508-017-1031-4 
Sistema Genito - Urinario y Endocrino

\section{Capítulo V}

ENFERMEDADES DE TRANSMISION SEXUAL 


\section{Sistema Genito - Urinario y Endocrino}

\section{CAPITULO XII \\ ENFERMEDADES DE TRASMISION SEXUAL}

Se puede tomar diversas medidas para prevenir el contagio de las enfermedades de transmisión sexual u otro trastorno del aparato reproductor.

I. Se debe emplear un preservativo masculino y femenino masculino o femenino para protegerse durante las relaciones sexuales vaginales y anales, se debe comprobar la fecha de caducidad

2. Entre las practica sexuales y segura cabe incluir el sexo sin penetración, este puede ser tan satisfactorio placentero como el sexo con penetración

3. Si se presenta cualquier secreción vaginal anómala o cualquier otro síntoma ETS se debe consultar a un médico de inmediato, a pesar de cualquier sentimiento de vergüenza que se pueda sentir. Es importante que se diagnostique y trate cuanto antes, para evitar que se contagie a otras personas o que los síntomas se agraven y se presente complicaciones importantes, como infertilidad

4. Se deben evitar los contactos sexuales hasta que la ETS se haya tratado con éxito en ambos miembros de la pareja

5. Si se diagnostica una ETS, se debe informar a las parejas sexuales actuales $y$ anteriores, también se tiene que tratar para evitar que la infección se difunda más

6. Las ETS sueles ser múltiple, por lo que si se diagnostica una el médico deberá comprobar para ver si hay otras presentes

7. Las infecciones tales como la candidiasis se puede prevenir evitando el uso de ropa interior de nailon este material sintético impide que el aire circules cerca de la piel y proporciona un entorno cálido y húmedo adecuado para que se desarrolle las infecciones 


\section{Sistema Genito - Urinario y Endocrino}

8. Se debe mantener el área genital bien limpia los genitales y el ano se debe lavar a diario con agua y un jabón suave.

\section{ETS víricas}

Las enfermedades de transmisión sexual provocada por virus incluyen las verrugas genitales y el herpes genital. La más grave es el sida.

\section{Verrugas genitales.}

Las verrugas blandas conocidas como condiloma crecen sobre o alrededor del pene del hombre, y alrededor de la vagina y el ano de la mujer. Está provocando por un papiloma humano VPH y se trasmite por contacto sexual puede tardar hasta 18 meses en aparecer. NO afecta a la fertilidad, aunque se cree que algunas capas están relacionadas con un aumento de riesgo de cáncer de cuello uterino, vaginal, anal, vulvar y peniano.

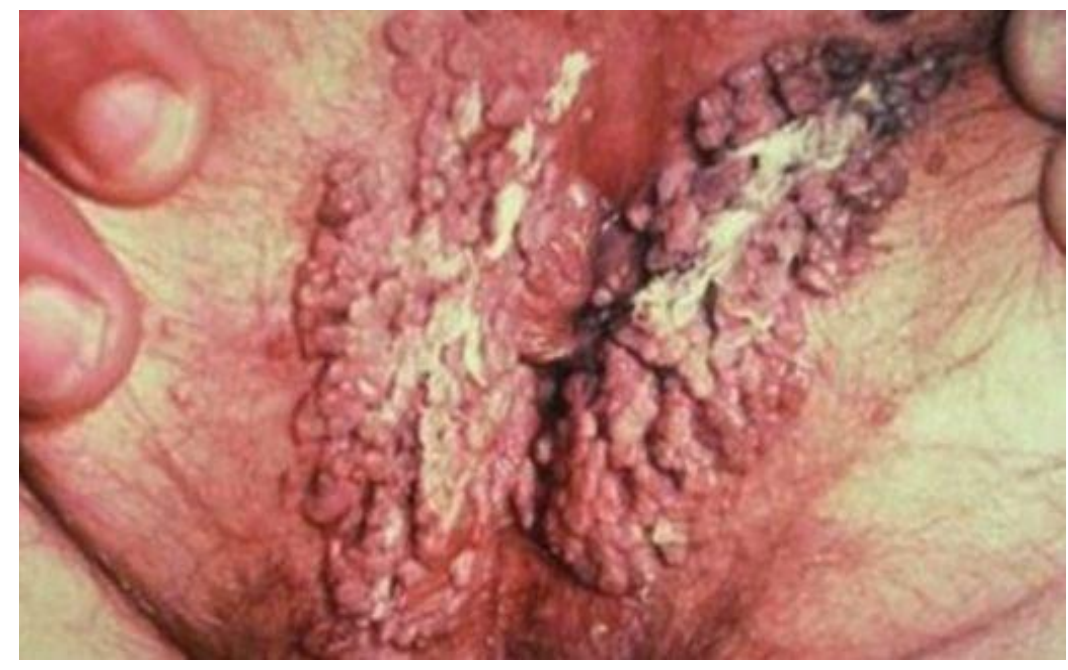

\section{Virus papiloma humano}

\section{Diagnóstico diferencial}

\section{Casos masculinos}

Debe hacerse con las pápulas perladas del surco balanoprepucial. Se debe hacer diagnóstico diferencial con queratosis seborreicas y solares, nevos, acrocordones, callos, 


\section{Sistema Genito - Urinario y Endocrino}

carcinomas espino celulares, melanoma amelanótico, liquen plano, moluscos contagiosos, hemorroides, condilomas planos y glándulas parafrenillo.

\section{Diagnóstico definitivo}

I. Revisión visual de las verrugas en pene, escroto, zona perianal o anal.

2. Un examen especial de la uretra (el conducto que fluye a través de la orina) en busca de verrugas. Generalmente este examen lo hace un médico especialista llamado urólogo.

3. Para una revisión de la zona anal es posible que se use un aparato especial para mirar dentro del ano que se llama proctoscopio.

\section{Casos femeninos}

\section{Diagnóstico diferencial}

Su diagnóstico diferencial es muy similar al del hombre a diferencia de la micropapilomatosis labial, pliegues hipertróficos perianales, neoplasia intraepitelial en útero y vagina, carcinoma de cuello uterino, metaplasia cervical, erosión cervical. Los tumores pequeños y quistes de la vulva, deben de descartarse antes de diagnosticar condilomas acuminados, en particular el molusco contagioso y los quistes epidérmicos son muy similares. Los condilomas planos y una variación de la sífilis secundaria, también debe tomarse en cuenta.

\section{Diagnóstico definitivo}

Displasia del cuello del útero que puede detectarse a través de un examen citológico de células exfoliadas en una prueba de papanicolau o un examen de biopsia de cuello.

-Para lesiones en la vagina y cérvix- citología

-Lesiones de alto riesgo- colposcopia y biopsia.

\section{Tricomoniasis}

\section{Diagnóstico diferencial}

\section{Casos masculinos}

Se lo suele confundir con candidiasis, proctitis y uretritis. Cabe recalcar que esta enfermedad, por lo general, es asintomática y poco frecuente en el hombre 


\section{Sistema Genito - Urinario y Endocrino}

\section{Diagnóstico definitivo}

I. Examen de orina

2. Muestra de semen

3. Muestra de secreción uretral.

4. Liquido prostático

\section{Casos femeninos}

\section{Diagnóstico diferencial}

I. Vaginosis bacteriana

2. Infecciones por Candida SpP

3. Vulvovaginitis de etiología no infecciosa

4. Uretritis infecciosa no gonocócica

5. Debe realizarse un tamizado de los pacientes con trichomonosis para la búsqueda de otros patógenos de transmisión sexual, entre ellos Chlamydia trachomatis, Neisseria gonorrhoeae y el virus de la inmunodeficiencia humana.

\section{Diagnóstico definitivo}

I. Examen pélvico

2. Citología vaginal

3. Fluido vaginal. 


\section{Sistema Genito - Urinario y Endocrino}

\section{Chancroide}

El chancroide es causado por una bacteria llamada Haemophilus ducreyi. Es una infección bacteriana de las mucosas genitales y que se disemina por contacto sexual. Se caracteriza por la aparición de pápulas, úlceras dolorosas y adenomegalias inguinales supuradas.

\section{Diagnóstico diferencial}

\begin{tabular}{|c|c|c|c|c|c|}
\hline Clínica & $\begin{array}{l}\text { Incubación } \\
\text { (días) }\end{array}$ & $\begin{array}{l}\text { Lesión } \\
\text { inicial }\end{array}$ & $\begin{array}{l}\text { Características } \\
\text { de las ulceras }\end{array}$ & $\begin{array}{l}\text { Características } \\
\text { de las } \\
\text { adenopatías } \\
\text { inguinales }\end{array}$ & $\begin{array}{l}\text { Otros } \\
\text { síntomas }\end{array}$ \\
\hline Chancroide & $2-12$ & $\begin{array}{l}\text { Mácula } \\
\text { Pápula } \\
\text { pústula }\end{array}$ & $\begin{array}{l}\text { Purulenta } \\
\text { Irregular } \\
\text { Dolorosas } \\
\text { Múltiples }\end{array}$ & $\begin{array}{l}\text { Puede formar un } \\
\text { cráter y supurar } \\
\text { dolorosa }\end{array}$ & Dolor local \\
\hline $\begin{array}{l}\text { Herpes } \\
\text { simple } 2\end{array}$ & $2-7$ & Vesícula & $\begin{array}{l}\text { Vesículas } \\
\text { múltiples } \\
\text { Generalmente } \\
\text { doloras }\end{array}$ & $\begin{array}{l}\text { Adenopatías } \\
\text { múltiples, } \\
\text { bilaterales, } \\
\text { pequeñas } \\
\text { dolorosas }\end{array}$ & $\begin{array}{l}\text { Mialgias } \\
\text { cefaleas }\end{array}$ \\
\hline Sífilis & 21 & Pápula & $\begin{array}{l}\text { No dolorosa } \\
\text { Profunda } \\
\text { Base limpia } \\
\text { Cura } \\
\text { espontáneamente }\end{array}$ & $\begin{array}{l}\text { Duras } \\
\text { No dolorosas }\end{array}$ & Asintomático \\
\hline
\end{tabular}




\section{Sistema Genito - Urinario y Endocrino}

\section{Diagnóstico definitivo}

I. Evaluación clínica

2. Puede ser necesario cultivo o evaluación con PCR (reacción en cadena de la polimerasa)

La dificultad para el diagnóstico bacteriológico mediante cultivo hace que sea necesario repetir tomas y hacer meticulosamente el diagnóstico diferencial con otras úlceras. Asimismo, se puede realizar una biopsia de las lesiones presentadas, la cual es siempre diagnóstica.

\section{Herpes genital}

Provocada por el virus herpes simple tipo II y de transmisión sexual, en algunas personas el herpes genital no produce síntomas, pero en otra la infecciones causa la aparición de dolorosas vesículas alrededor de los genitales acompañado de un intenso picor local, quemazón e irritación. Si la vesículas estallan, pueden producir ulcera dolorosa.

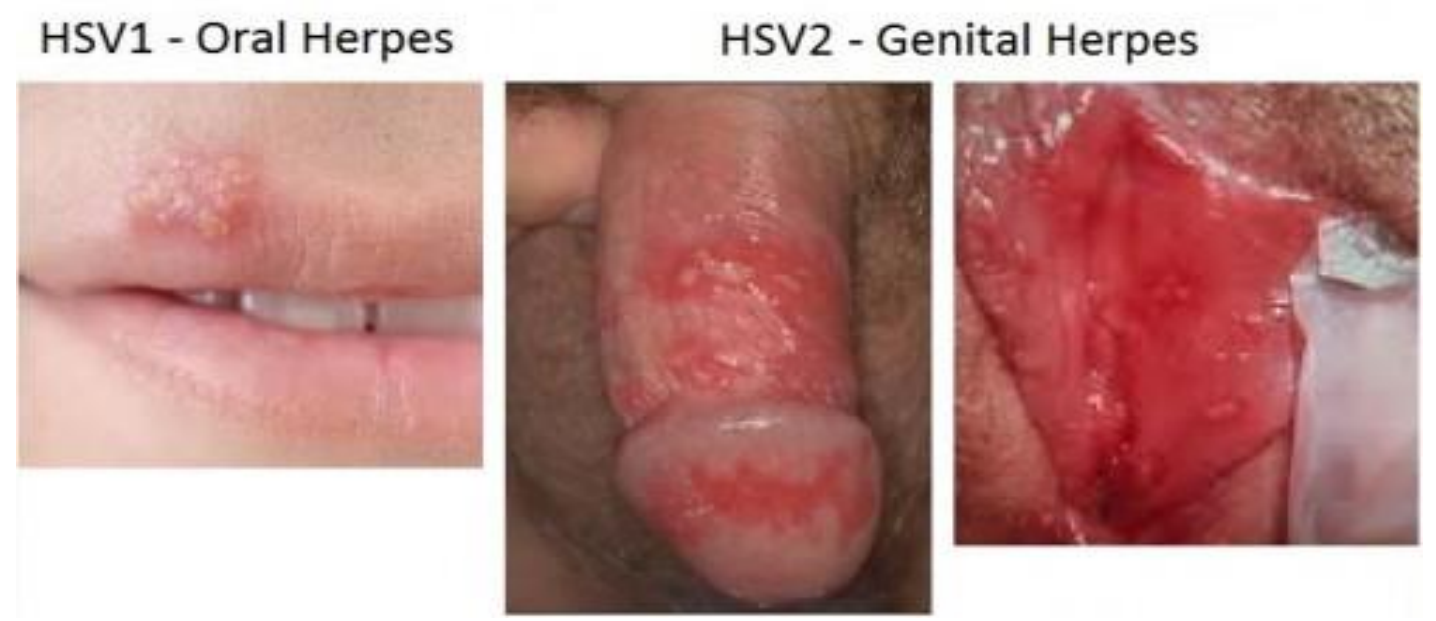

La presencia del virus también posibilitan que el paciente se sienta febril, y los ganglios linfáticos de la ingles a menudo se hinchan. Las mujeres embarazada con vesículas provocada por el herpes genital en el momento de parto deberían recurrir a la cesaría para evitar infectar al recién nacido. 


\section{Sistema Genito - Urinario y Endocrino}

Una vez aparece el virus, permanece durante toda la vida. Sin embargo, el 20 por ciento de los afectados solamente sufre un ataque, y en caso de que se repitan los síntomas suele ser menos intensos. Es importante abstenerse de mantener relaciones sexuales cuando están presentes los síntomas, para evitar contagiar la infección a la pareja. Los ataques pueden ser desencadenados por el estrés, la ansiedad la depresión, menstruación y las relaciones sexuales.

El herpes genital es una enfermedad de transmisión sexual causada por el virus del herpes simple. Puede causar llagas en el área genital o rectal, nalgas y muslos. Puede contagiarse al tener relaciones sexuales vaginales, anales u orales con alguien que lo tenga. El virus puede contagiarse aun cuando las llagas no están presentes. Las madres pueden infectar a sus bebés durante el parto. A los síntomas se los llaman comúnmente brotes. Las llagas aparecen usualmente cerca del área donde el virus ingresó al cuerpo. Existen exámenes que pueden diagnosticar el herpes genital. No existe cura. Sin embargo, las medicinas pueden ayudar a disminuir los síntomas, reducir los brotes y bajar el riesgo de contagio a otras personas.

\section{DIAGNÓSTICO DIFERENCIAL}

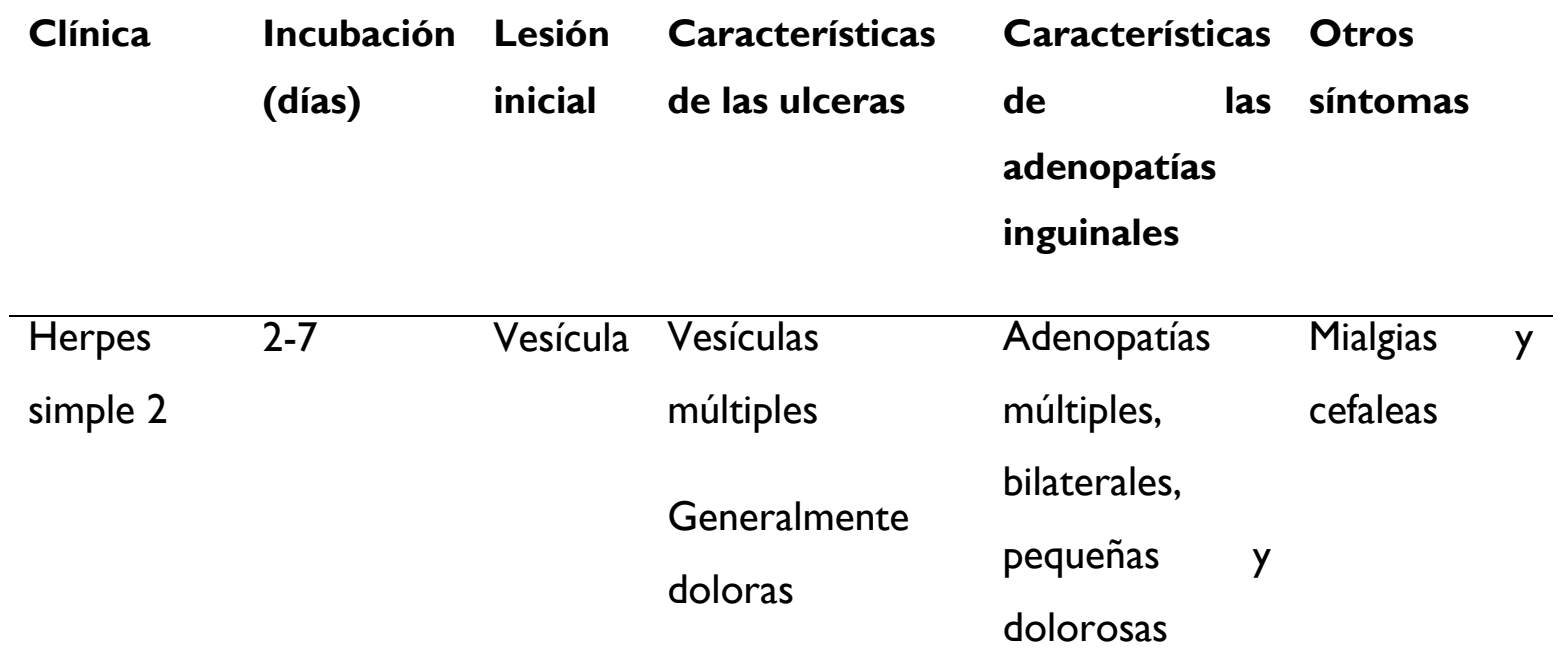




\section{Sistema Genito - Urinario y Endocrino}

\begin{tabular}{|c|c|c|c|c|c|}
\hline Sífilis & 21 & Pápula & No dolorosa & Duras & Asintomático \\
\hline & & & Profunda & No dolorosas & \\
\hline & & & Base limpia & & \\
\hline & & & Cura & & \\
\hline & & & espontáneamente & & \\
\hline Chancroide & $2-12$ & Mácula & Purulenta & Puede formar & Dolor local \\
\hline & & Pápula & Irregular & $\begin{array}{l}\text { un cráter y } \\
\text { supurar }\end{array}$ & \\
\hline & & pústula & Dolorosas & dolorosa & \\
\hline & & & Múltiples & & \\
\hline
\end{tabular}

\section{Diagnóstico definitivo}

Cultivo del virus: Esta prueba consiste en tomar una muestra de tejido o raspado de las llagas para su análisis en el laboratorio.

Prueba de PCR: La prueba de ADN viral requiere la recolección de una muestra del líquido que se encuentra en las ampollas. La muestra se recoge usando un hisopo de algodón. La muestra se envía a un laboratorio para cultivar el virus o para hacer la prueba en busca del ADN del virus del herpes simple. Esta prueba permite determinar qué tipo de virus herpes afecta el paciente (virus herpes I $\circ 2$ ).

Pruebas en sangre: Las pruebas serológicas son análisis de sangre que detectan los anticuerpos contra el virus del herpes. Varias pruebas serológicas basados en ELISA están disponibles comercialmente. 


\section{Sistema Genito - Urinario y Endocrino}

\section{VIH SIDA}

\section{Diagnóstico diferencial}

El VIH está asociado a la aparición de un número variable de otras enfermedades, que pueden ser más leves y pasajeras o más graves y duraderas. Conocer bajo qué condiciones suelen manifestarse y cómo te ayudará a tomar decisiones sobre su prevención y tratamiento.

Candidiasis: La candidiasis o micosis candidiásica es una enfermedad causada por el hongo Cándida albicans. Se trata de una infección oportunista, puesto que se manifiesta y progresa cuando el sistema inmune está muy deteriorado por el avance de la infección por $\mathrm{VIH}$. Las infecciones oportunistas pueden estar causadas por distintos tipos de microorganismos como virus, bacterias, hongos y parásitos

Cáncer cervical: Las lesiones precancerosas de cuello uterino son las precursoras del cáncer cervical y la infección por el virus del Papiloma humano (VPH) es el factor de riesgo más importante para su desarrollo. El cáncer cervical está considerado oficialmente una enfermedad definitoria de SIDA.

La demencia asociada a SIDA es una alteración neurológica y un síndrome que tiene una característica que la hace diferente a otras enfermedades relacionadas con el $\mathrm{VIH}$.

Neumonía bacteriana: La neumonía bacteriana es una enfermedad común entre las personas con VIH y bajos recuentos de CD4. Se trata de una infección de las vías respiratorias y puede ser causada por varios tipos de bacteria. La neumonía por Streptococcus y por Haemophilus influenzae son las más comunes

\section{Diagnóstico definitivo}

El SIDA (síndrome de inmunodeficiencia adquirida) es el estado avanzado de la enfermedad producida por el virus de la inmunodeficiencia humana (VIH). No existen síntomas iniciales que puedan hacer sospechar a una persona que se ha infectado con el virus de inmunodeficiencia humana $(\mathrm{VIH})$. Para comprobarlo, es necesario realizar un examen de sangre específico, denominado Prueba de Anticuerpos al VIH (que es gratuita, inocua y confidencial). Si la prueba es positiva indica que la persona tiene el 


\section{Sistema Genito - Urinario y Endocrino}

virus, pero eso no significa que haya desarrollado la enfermedad, ni que necesariamente vaya a desarrollarla. Hay muchas personas que están infectadas sin saberlo, de ahí la importancia de un diagnóstico precoz, que evitaría nuevos contagios. Hay que tener en cuenta también que, aunque la prueba es muy sensible y capaz de detectar cantidades muy pequeñas de anticuerpos, si el resultado es positivo, es necesario realizar una segunda prueba para confirmar la infección.

\section{SÍFILIS}

\section{Diagnóstico diferencial}

Un médico puede decir si tienes la sífilis con una prueba de sangre o sacándole fluido de las lesiones. A todas las personas que tienen sífilis se les recomienda hacerse la prueba del VIH porque las lesiones de sífilis pueden causar más fácilmente la transmisión del $\mathrm{VIH}$. Las personas que tienen sífilis primaria deberían examinarse para el VIH después de 3 meses si es que el primer examen de $\mathrm{VIH}$ resultó negativo.

\section{Diagnóstico definitivo}

La sífilis es una infección curable, causada por una bacteria llamada Treponema Pallidum. La bacteria ingresa al cuerpo a través de las membranas mucosas o piel erosionada (roto o cortado). Una vez dentro del cuerpo, la sífilis entra en el torrente sanguíneo y se adhiere a las células, órganos dañinos a lo largo del tiempo.

La sífilis no tratada progresa por cuatro etapas. Cada etapa tiene sus propios signos y síntomas únicos: primaria, secundaria, latente, y terciaria (o tarde). La sífilis no tratada puede producir síntomas a partir de 17 días hasta 30 años. Mientras la sífilis es curable con antibióticos, las complicaciones que se pueden presentar en las etapas posteriores no se pueden revertir con el tratamiento.

\section{Otras infecciones}

Los órganos productores también pueden verses afectados por otras infecciones que no necesariamente son de transmisión sexual. Entres ella se incluyen las enfermedades inflamatoria pélvica y a la candidiasis. 


\section{Sistema Genito - Urinario y Endocrino}

\section{BIBLIOGRAFÍA SUGERIDA}

1. Burd EM, Dean CL. Human Papillomavirus. Microbiol Spectr. 2016;4(4):10.1128/microbiolspec.DMIH2-0001-2015.

doi:10.1128/microbiolspec.DMIH2-0001-2015

2. Araldi RP, Sant'Ana TA, Módolo DG, et al. The human papillomavirus (HPV)-related cancer biology: An overview. Biomed Pharmacother. 2018;106:1537-1556. doi:10.1016/j.biopha.2018.06.149

3. Taberna M, Mena M, Pavón MA, Alemany L, Gillison ML, Mesía R. Human papillomavirus-related oropharyngeal cancer. Ann Oncol. 2017;28(10):23862398. doi:10.1093/annonc/mdx304

4. Copeland NK, Decker CF. Other sexually transmitted diseases chancroid and donovanosis. Dis Mon. 2016;62(8):306-313. doi:10.1016/j.disamonth.2016.03.016

5. Vestergaard T. Ugeskr Laeger. 2018;180(20):V01180024.

6. Groves MJ. Genital Herpes: A Review. Am Fam Physician. 2016;93(11):928-934.

7. Koren M, Decker CF. Genital herpes. Dis Mon. 2016;62(8):287-293. doi:10.1016/j.disamonth.2016.03.013

8. Eisinger RW, Fauci AS. Ending the HIV/AIDS Pandemic ${ }^{1}$. Emerg Infect Dis. 2018;24(3):413-416. doi:10.3201/eid2403.171797

9. Shadyab AH, Hale BR, Shaffer RA. HIV/AIDS Securitization: Outcomes and Current Challenges. Curr HIV Res. 2017;15(2):78-81. doi:10.2174/1570162X15666170516163834

10.Salado-Rasmussen K, Katzenstein TL, Larsen HK. Ugeskr Laeger. 2018;180(20):V01180026.

11.Dupin N. Syphilis [Syphilis]. Rev Med Interne. 2016;37(11):735-742. doi:10.1016/j.revmed.2016.05.010

12. Heston S, Arnold S. Syphilis in Children. Infect Dis Clin North Am. 2018;32(1):129-144. doi:10.1016/j.idc.2017.11.007 
Sistema Genito - Urinario y Endocrino

Capítulo VI
Problemas en el embarazo y en el nacimiento 


\section{Sistema Genito - Urinario y Endocrino}

\section{CAPITULO VIII}

\section{PROBLEMAS EN EL EMBARAZO Y EN EL NACIMIENTO}

La mayoría de los embarazos y nacimientos se desarrollan sin problemas pero de vez en cuando las cosas salen mal para la madre, el hijo o ambos. Los problemas con el embarazo y el nacimiento se incluyen en una de estas tres categorías: los que afectan a la madre, los que afectan a la madre y tienen repercusión en el feto y los que afectan al feto. El cuidado prenatal constituye un medio eficaz de anticiparse y controlar estos problemas. De un modo general podemos decir que muchos de los problemas que afectan a la madre también afectaran al feto mientras se encuentre en el útero. De todas maneras, las categorías que aquí se describen nos ayudaran a identificar los diferentes problemas.

\section{Trastornos que afectan a la madre}

Entre las complicaciones maternas que aparecen durante y después del embarazo se cuentan en el embarazo ectópico, aborto, problemas placentarios, preeclampsia y eclampsia. La anemia y la mastitis son menos graves, pero pueden provocar diferentes grados de incomodidad a la madre.

\section{Embarazo ectópico}

Aproximadamente, en uno de cada 150 embarazos, el ovulo, en lugar de implantarse en el útero, se implanta en algún otro lugar. Es lo que se conoce como embarazo ectópico o embarazo extrauterino. Muy ocasionalmente, el ovulo se desarrolla en el ovario, en la capacidad abdominal o en el cuello uterino. Alrededor del $95 \%$ de los embarazos ectópicos el ovulo empieza a desarrollarse en la trompa de uterina. La causa más frecuente de este tipo de embarazo es una enfermedad inflamatoria pélvica, que lesiona la trompa y el delicado recubrimiento interno, sobre él normalmente se desliza el ovulo hasta el útero. 


\section{Sistema Genito - Urinario y Endocrino}

El uso de un dispositivo intrauterino contraceptivo (DIU), manipuladora o fertilización in vitro también aumenta la probabilidad de un embarazo ectópico. Una vez el ovulo ha anidado en la trompa uterina, el embrión empieza a desarrollarse y crecer. Los síntomas aparecen sobre las seis semanas de gestación, y consisten en ligeras hemorragias y dolor. A veces la trompa uterina se llega a romper, provocando dolor abdominal muy intenso y hemorragias, emergencia que requiere de cirugía inmediata para extraer el embrión y reparar la trompa afectada. El diagnostico precoz puede evitar que se rompa la trompa. Aunque se haya extirpado una trompa, se puede desarrollar un embarazo normal, pero si se han dañado ambas se hará necesario un tratamiento de FIV.

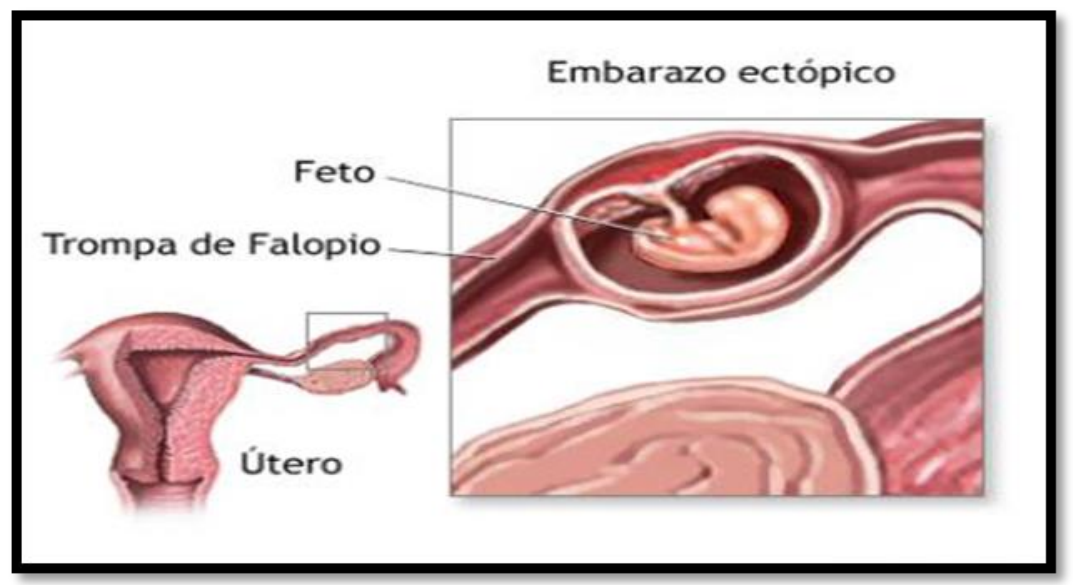

\section{Aborto}

Hasta un tercio de embarazos se cree que terminan en aborto (aborto espontaneo). Muchos abortos pasan desapercibidos, porque antes o aproximadamente en la fecha que debería aparecer el periodo. Sin embargo, cerca de 15-20\% de los embarazos confirmados se pierden en el primer trimestre o a principios del segundo. La mayoría de los abortos se deben a problemas en el ovulo fecundado. El trofoblasto se desarrolla y empiezan a producirse los cambios hormonales propios del embarazo, pero el embrión no consigue desarrollarse. Habitualmente, cuando la mujer vuelve a quedar embarazada, el feto llega sano hasta el nacimiento.

Algunas mujeres (menos del $1 \%$ ) sufren abortos recurrentes, la perdida de tres o cuatro fetos seguidos. Esta clase de aborto puede ser el resultado de una anomalía genética o 


\section{Sistema Genito - Urinario y Endocrino}

uterina, infección crónica, autoinmune, metabólica o trastornos hormonales. Sin embargo, en la mitad de los casos no se conoce el motivo. Los síntomas más habituales del aborto son una hemorragia vaginal y dolor abdominal. Si se produce una hemorragia en cualquier momento del embarazo, se debe consultar a un médico.

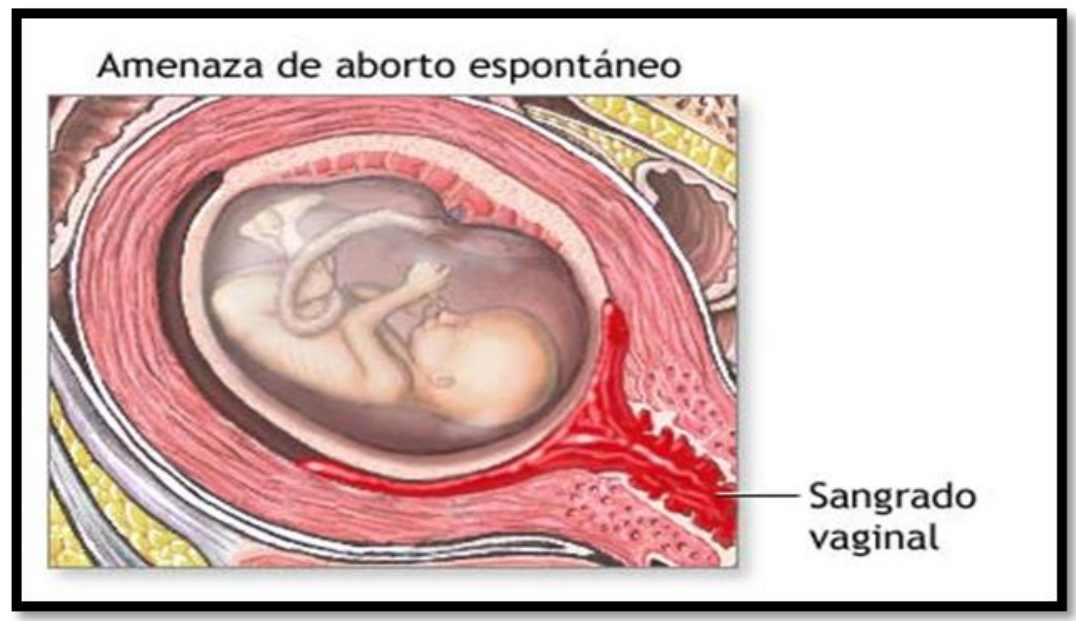

\section{Desprendimiento de placenta y hemorragias antepartum}

La separación completa o parcial de la pared uterina puede provocar una hemorragia vaginal durante el embarazo (hemorragia antepartum). Esta situación puede ir asociada a una preeclampsia, pero a menudo no se le encuentra una causa. Esta enfermedad es de gravedad variable, y si la pérdida es leve y la ecografía muestra que la placenta está bien colocada, el embarazo puede continuar hasta el final. El desprendimiento de la placenta se produce en uno de cada 200 embarazos. En la forma más grave, en la que se separa más de dos tercios de la placenta y se pierden hasta dos litros de sangre, hay un alto riesgo de muerte fetal. Aparece súbitamente un dolor abdominal intenso, y al palpar el feto se nota duro. Es una emergencia médica que requiere una transfusión de sangre inmediata y una cesárea para salvar el feto. 


\section{Sistema Genito - Urinario y Endocrino}

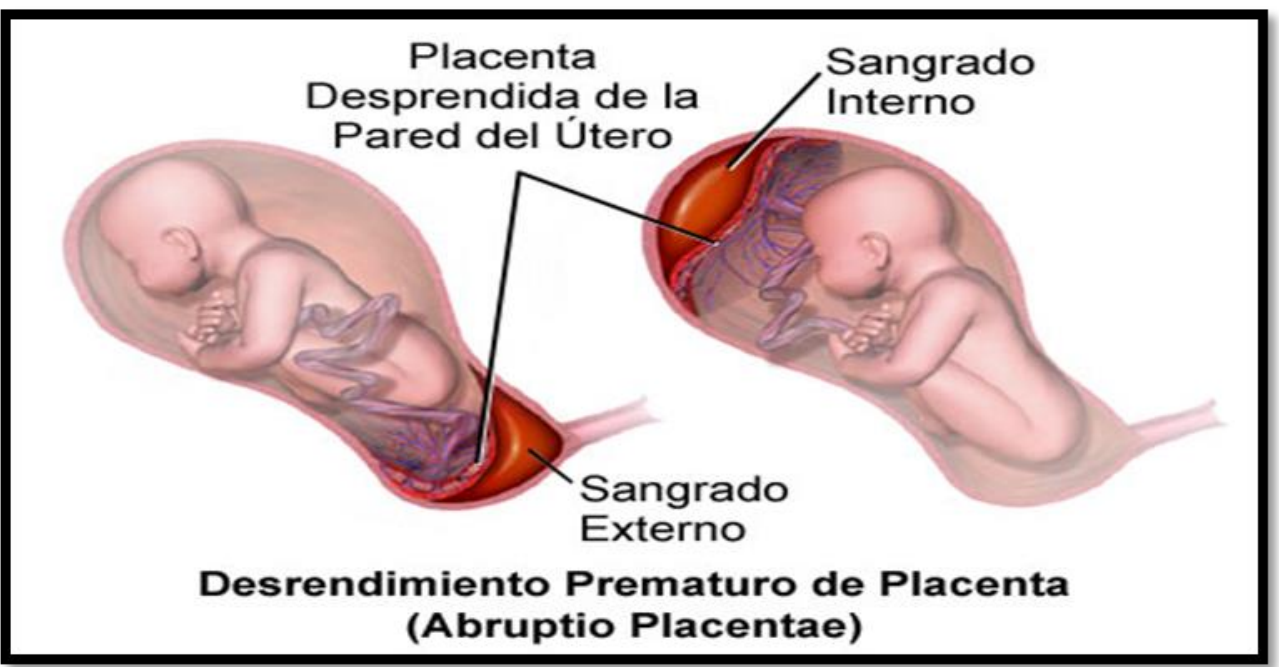

\section{Insuficiencia placentaria}

Se trata de un funcionamiento anómalo de la placenta. Puede darse cuando se alarga el embarazo, o a consecuencia de una elevada presión arterial, preeclampsia, hemorragias preparto o en el caso de una mujer fumadora. La insuficiencia placentaria impide que el feto obtenga oxígeno y nutrientes suficientes y puede necesitar la inducción del parto o cesárea.

\section{INSUFICIENCIA PLACENTARIA}
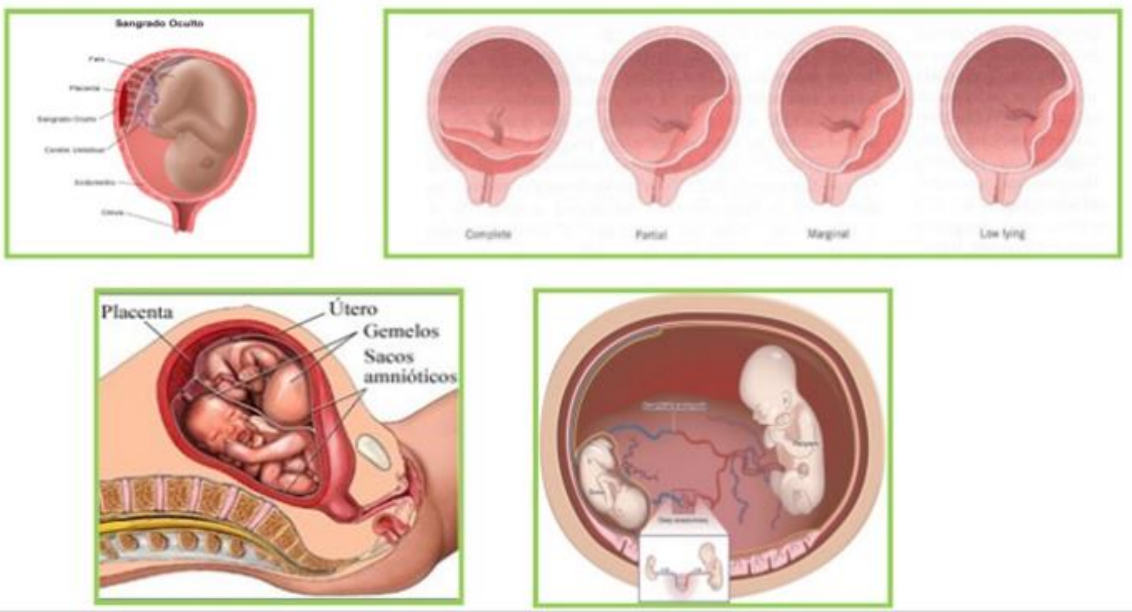


\section{Sistema Genito - Urinario y Endocrino}

\section{Placenta previa}

Si la placenta se encuentra en el segmento uterino inferior, la situación se conoce como placenta previa. Cuando el útero se contrae al final del embarazo, la placenta empieza a desprenderse de la pared uterina, originando hemorragias vaginales. A menudo las ecografías al principio del embarazo muestran una placenta aparentemente baja. Sin embargo, a medida que el útero crece y se dilata, y se va formando el segmento uterino inferior, la placenta va ascendiendo hacia el superior.

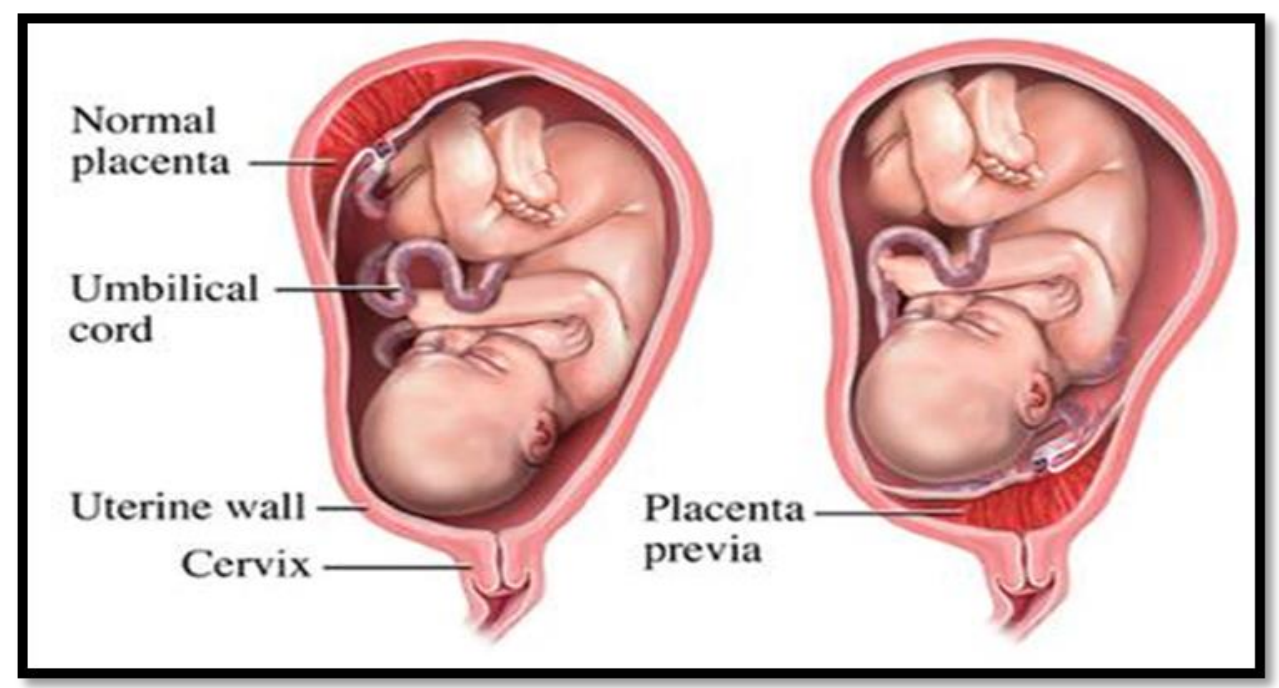

\section{Pre - eclampsia y eclampsia}

La hipertensión inducida por el embarazo (HIE) se conoce como pre - eclampsia, y si no se trata puede llevar a una eclampsia y, posiblemente, a una muerte fetal o materna. La pre - eclampsia se da cerca del $10 \%$ de los embarazos, y es quince veces más probable en la mujeres primerizas que en las que no lo son. Es más frecuente en adolescentes jóvenes y en mujeres de más de 35 años, aunque algunas mujeres parecen tener una predisposición genética a padecerla. La causa de la pre - eclampsia no se conoce.

Cuando se ha dado a luz, el cuadro desaparece.

En la pre - eclampsia las células endoteliales del recubrimiento interno de los vasos sanguíneos se dañan y no cumplen adecuadamente su función. Los vasos sanguíneos de la 


\section{Sistema Genito - Urinario y Endocrino}

placenta se estrechan y se vuelven rígidos, de manera que a través de ellos puede pasar menos sangre y el feto recibe menos oxígeno y nutrientes.

La eclampsia es una emergencia porque el extenso daño de los vasos sanguíneos provoca la muerte del feto $y$, en la madre, fallo renal, hemorragia cerebral y convulsiones.

La pre - eclampsia y eclampsia son dos de los cuadros más graves del embarazo. A pesar de los avances realizados en obstetricia, antes, durante y después del nacimiento, siguen siendo las principales causas de muerte materna y fetal.

\section{Anemia}

Normalmente se debe a un déficit de hierro y afecta negativamente al estado de salud general de la mujer, la anemia influye en la capacidad de defenderse de las infecciones. La anemia grave de la madre, es rara en el mundo desarrollado, puede provocar un fallo cardíaco y dañar su capacidad de transferir oxígeno y otros nutrientes al feto. Sin embargo, estos solamente ocurren en los casos graves de anemia que no reciben tratamiento alguno. La hemorragia preparto y posparto también tiene consecuencia más graves si la madre esta anémica.

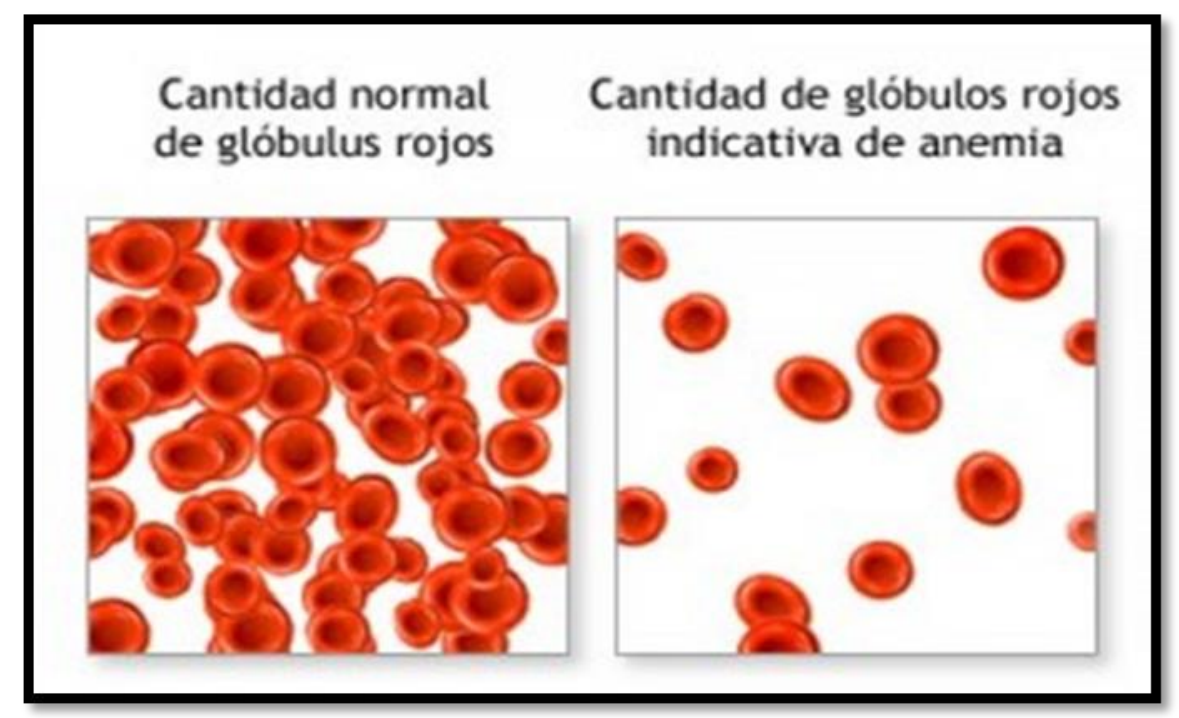




\section{Sistema Genito - Urinario y Endocrino}

\section{Mastitis}

La infección de los pechos, conocida como mastitis, puede aparecer en cualquier momento de la lactancia y afectar a un pecho o a ambos.

La mastitis es frecuente sobre todo en el periodo inmediatamente posnatal, a causa de un excesivo llenado de leche de los pechos (congestión) e irritación de los pezones.

La infección está provocada por la bacteria staphylococcus aureus. Microorganismo responsable de la mayoría de infecciones cutánea. Dicho microorganismo que puede estar presente en la nariz del bebe, entra a través de una grieta en un pezón cuando el niño está mamando. Los síntomas son dolor, la localización de una zona enrojecida, dura y sensible en el pecho, e inflamación de los ganglios axilares.

La madre no se encuentra bien y padece fiebre y aumento de la frecuencia cardíaca.

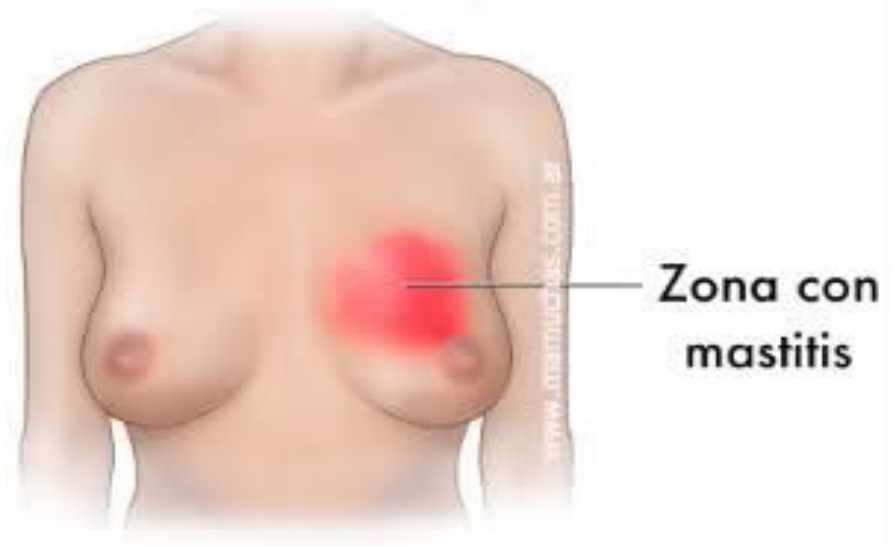

\section{Trastornos maternos que afecta al niño}

El feto en desarrollo puede verse afectado por las infecciones de la madre, incluida las provocadas por las bacterias, trasmisiones sexuales y la rubeola.

\section{Infecciones}

Hay una serie de infecciones de la madre que pueden afectar al desarrollo del feto. La rubeola (sarampión alemán), una enfermedad habitual y normalmente leve, puede provocar sordera, ceguera, malformaciones cardiacas y retraso intelectual en él bebe.

\section{La listeriosis}




\section{Sistema Genito - Urinario y Endocrino}

Provocada por la bacteria listeria monocitogenes, es una infección que puede contraerse al ingerir determinado alimentos como derivados lácteos no pasteurizados.

\section{La Clamidia}

Bacteria que se transmite por vía sexuales y con mayor frecuencia en las mujeres, aumenta en riesgo de embarazo ectópicos pero suele asociarse a mas problemas de infertilidad. Sin embargo, puede aumentar el riesgo de un parto prematuro y de escasez de peso del neonato. Si pasa el bebe cuando desciende por el canal del parto, puede provocarle conjuntivitis y neumonía. La sífilis puede provocar retraso del crecimiento, enfermedades óseas y cerebrales en el feto, nacimiento prematuro o mortonatos.

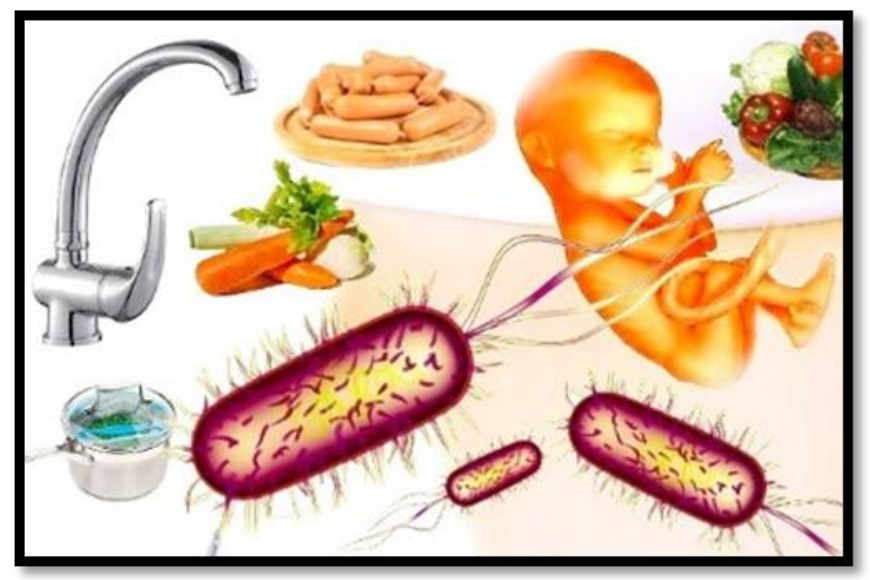

\section{Vacunaciones}

A las mujeres embarazadas no se le debe administrar vacunas formadas por microorganismo vivos, a menos que haya un riego significativo de exposición, por ejemplo, a la fiebre amarrilla o a la poliomielitis, en el que la necesidad de la vacunación compense al riesgo.

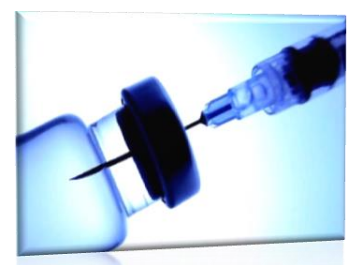




\section{Sistema Genito - Urinario y Endocrino}

\section{Complicación que afectan al feto}

El feto puede verse afectado por algún cuadro que provoque problemas durante el parto como el colapso del cordón umbilical; en ocasiones, éste puede morir mientras esta en el útero, durante el parto o poco después de éste.

\section{Problemas de parto}

Algunas patologías que afectan al feto pueden complicar el parto entre estas se incluye, el prolapso del cordón umbilical, presentación de nalgas y nacimientos prematuros y desproporción pélvicas fetal.

\section{Prolapso del cordón umbilical}

Después de romper aguas, el cordón umbilical pasa por el cuello uterino hacia la vagina por delante del feto, se produce lo que se denomina un prolapso. Puede suceder en cualquier situación en la que la cabeza del feto este muy alta o mal puesta. Existe el riesgo en la que la presión de la cabeza de este contra el cordón corte el suministro del oxígeno de manera que es esencial que él bebe nazca rápidamente. Si el cuello uterino está completamente dilatado cuando se prolapsa el cordón, puede requerirse una episiotomía. Si no está totalmente dilatado se practica una cesaría.

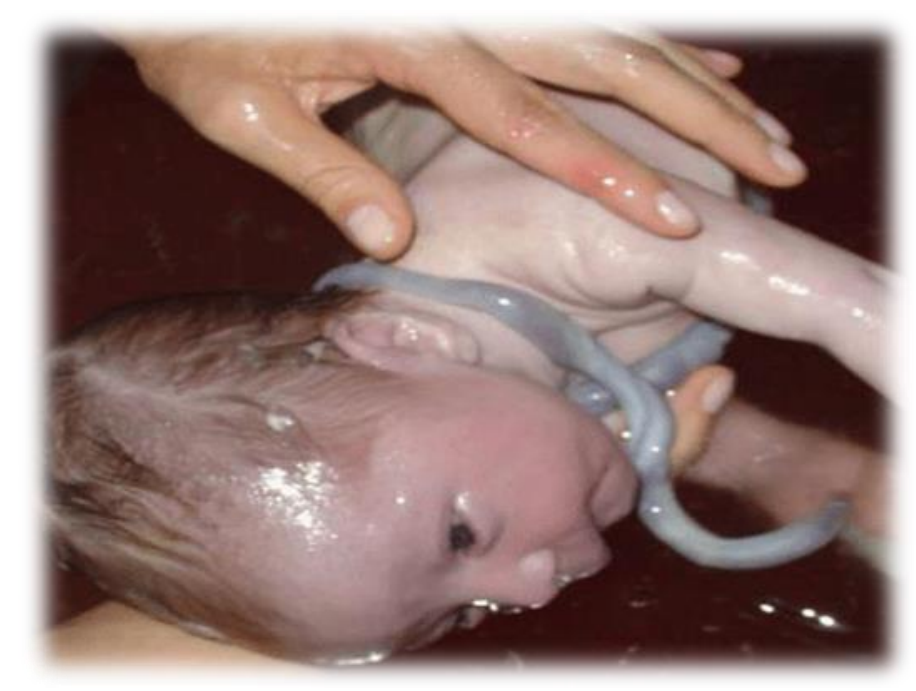




\section{Sistema Genito - Urinario y Endocrino}

\section{Parto de nalgas}

Si el feto tiene un tamaño normal y la pelvis de la madre es adecuada, el parto de nalga no tiene por qué ser más difícil o peligroso que un parto normal. El principal problema que genera ese tipo de parto se halla en que si la cabeza (parte más ancha del feto) no sale en primer lugar, no es seguro que pase fácilmente por la pelvis de la madre una vez que lo haya hecho el resto del cuerpo. Si el feto es grande, su cabeza no se flexiona bien o la pelvis de la madre es estrecha, el parto de nalgas puede tener un cierto riesgo para el bebé y puede ser necesaria una cesárea. El peligro principal es la anoxia, una falta de oxígeno provocada por el aplastamiento del cordón entre la cabeza del feto y la pelvis de la madre, lo cual puede llegar a provocar una lesión cerebral o la muerte del bebe.

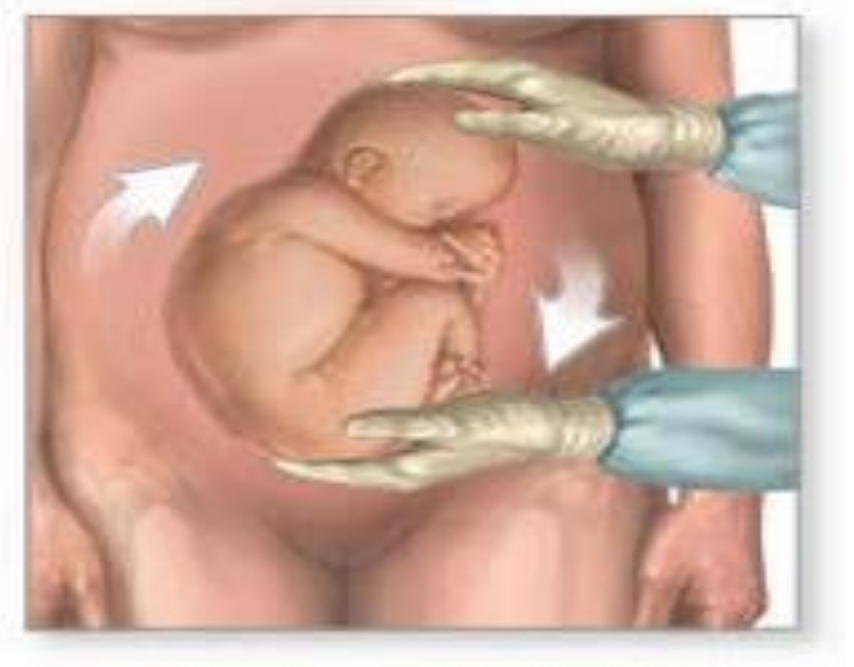

\section{Parto y nacimiento prematuro}

Un parto prematuro es la que empieza antes de las trigésima séptima semana de gestación. Puede ser el resultado de problemas médicos previos, como una diabetes o una tensión arterial elevada, o trastornos generados por el embarazo, como eclampsia o preclamsia. Los partos prematuros son más frecuentes en madres más jóvenes y también en la de más edad, así como los embarazos múltiples. Un bebé prematuro puede sufrir problemas respiratorios para regular la temperatura corporal y tener dificultes alimentarias. 


\section{Sistema Genito - Urinario y Endocrino}

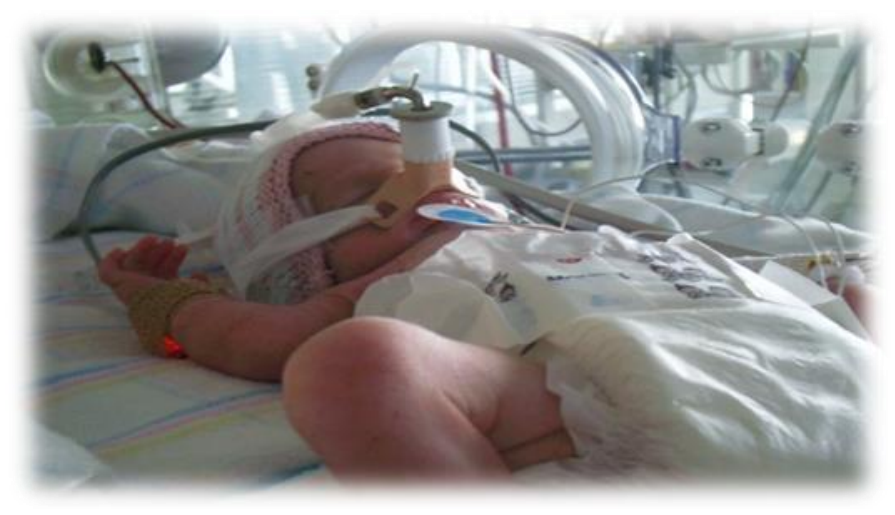

\section{Muerte del feto}

Si un feto muere antes de la vigésima octava semana de gestación se denomina aborto, un feto nacido muerto después de las veinte ocho semana de embarazo se denomina mortinata. La muerte intrapartum se produce cuando el feto muere durante el parto, y la muerte neonatal es la que acontece en las cuatro semanas posterior al parto. El feto tiene un mayor riesgo de morir en una gestación múltiple, bien en el útero o bien tras el nacimiento. Hoy día el peligro de que un bebé nazca muerto o muera poco después del nacimiento se ha producido en $1 \%$ en el mundo occidental.

\section{Mortinato}

Muy rara vez él bebe llega a morir en el útero, puede ser debido a una anomalía congénita o incompatibilidad de factor $\mathrm{RH}$ o desprendimiento de la placenta. La madre nota que ha cesado el movimiento fetal: la ecografía muestra que no hay latidos cardiacos, el útero deja de crecer y puede haber un flujo de color marrón.

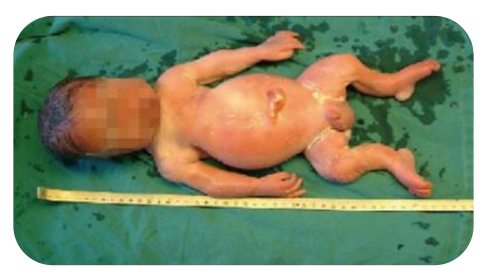




\section{Sistema Genito - Urinario y Endocrino}

\section{Muerte intrapartum}

El feto podría morir durante el parto, puede deberse a la falta de oxígeno durante el parto causada por un accidente con el cordón umbilical, desprendimiento de la placenta, contracciones hipertónicas o partos prolongados.

\section{Muerte neonatal}

Se produce en el plazo de cuatros semanas tras el parto, aunque la mayoría de bebes que mueren fallecen uno o dos días después de nacer. Las causas puede deberse a una sepsis neonatal infecciones respiratoria y gastrointestinal.

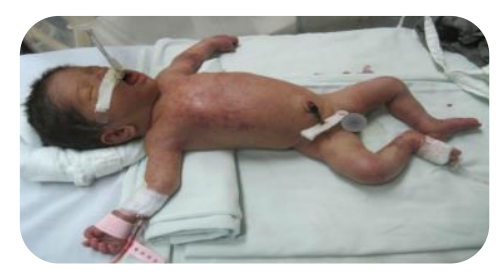

\section{Pérdida de un feto por embarazo múltiple}

Los embarazados múltiples se consideran de mayor riesgo porque los fetos tienen que compartir los recursos de la madre. A veces el feto recibe menos nutrientes que los demás lo que retrasa su crecimiento y en los casos graves puede provocar su muerte. Los fetos de embarazos múltiples también es más probable que nazca prematuramente, la mayoría nacen antes de las 36 semanas y pueden que necesiten pasar más tiempo en una unidad de cuidados neonatales.

\section{Anomalías congénitas}

Presente desde el nacimiento, pueden ser debidas a factores genéticos y alteraciones cromosómicas e infecciones maternas, el consumo de drogas, alcohol y tabaco $\circ$ la exposición a las radiaciones durante el embarazo; la edad de la madre y las deficiencias alimentarias pueden ser responsables. Ejemplos de éstos destacan los gemelos acoplados, 


\section{Sistema Genito - Urinario y Endocrino}

pies deformes, lesiones cardíacas, labios leporinos, y paladar escindo. Alteraciones del sistema nervioso central, parálisis cerebral y síndrome de Down.

\section{Gemelos acoplados}

Dos bebes que nacen físicamente unidos se conocen como gemelos acoplados o siameses. Son gemelos idénticos que por razones desconocidas no se llegan a separar durante el desarrollo a partir de un único ovulo fecundado, pueden ser individuos bien desarrollados unidos únicamente por la piel hasta los que comparten órganos, extremidades o el tronco.

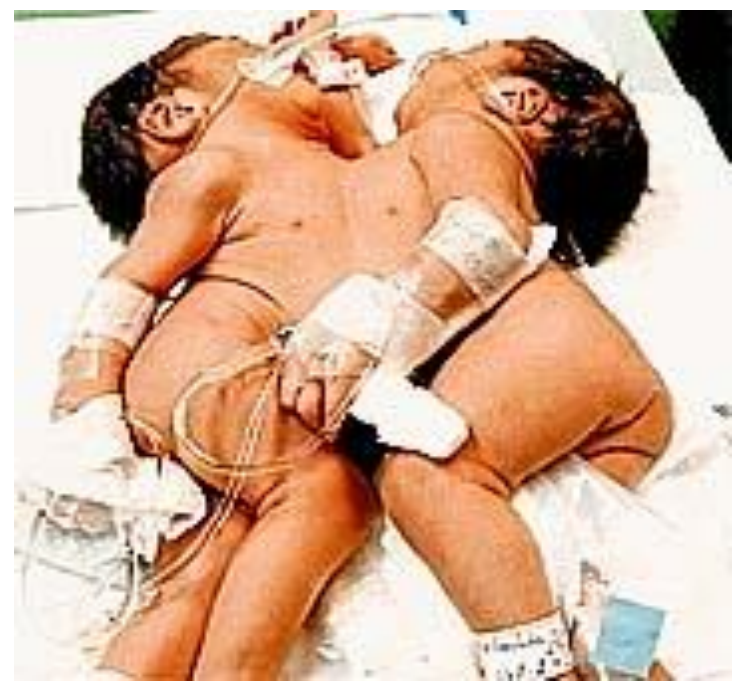

\section{Pie deforme}

Él bebe nace con la planta de un pie o de ambos dirigidos hacia abajo y hacia adentro, o hacia adentro y hacia afuera. 


\section{Sistema Genito - Urinario y Endocrino}

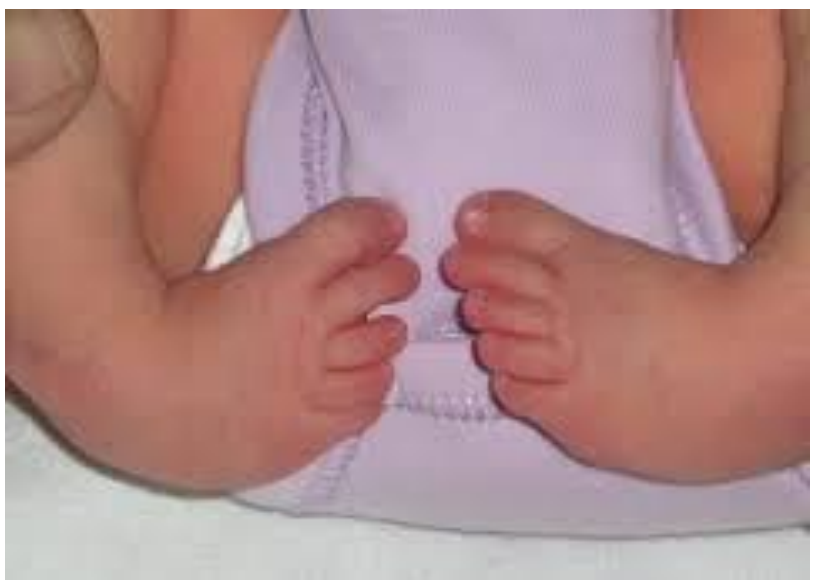

\section{Epispadias e hipospadias}

Son lesiones congénitas de la abertura peniana de la uretra. En las epispadias, la abertura está situada en la cara superior del pene, mientras que en la hipospadias la abertura está bajo el glande.

\section{Labio leporino y paladar escindido}

Son producidos por el desarrollo óseo incompleto de la cara del feto. El labio escindido es una fisura vertical del labio que puede llegar hasta la nariz. El paladar escindido, en cambio, es un hueco que suele aparecer cuando dos mitades del paladar no llegan a soldarse durante el desarrollo. Estas afecciones pueden aparecer aisladas o combinadas y causar dificultades para alimentar a los niños afectados.
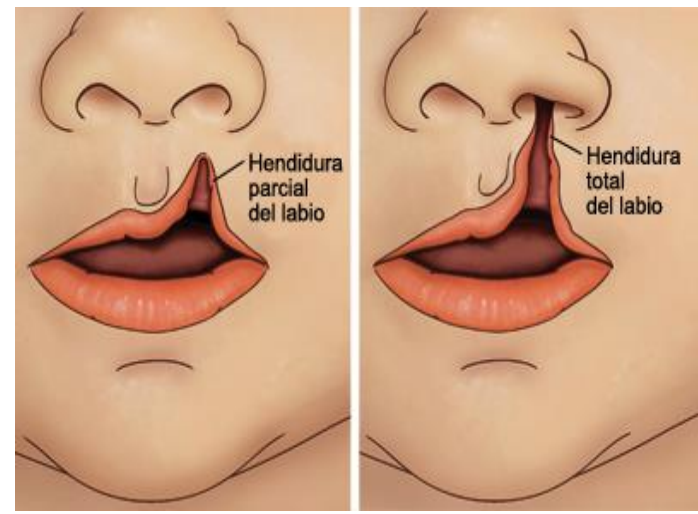


\section{Sistema Genito - Urinario y Endocrino}

\section{Lesiones del sistema nervioso central}

La espina bifídica y la hidrocefalia son anomalías del SNC. La hidrocefalia está causada por un acumulo excesivo de líquido cefalorraquídeo en el cerebro, y con frecuencia va asociada a la espina bifídica. En él bebe, la cabeza se hincha y continúa creciendo con anormal rapidez porque su cráneo es flexible.

\section{Parálisis cerebral}

Aparece debido a las lesiones cerebrales antes, durante o después del nacimiento. Los síntomas acostumbran a no ser evidente hasta que él bebé tiene varios meses y parece que su desarrollo se retrasa, el grado de incapacidad varía desde muy leve en el que el niño puede ser torpe o inestable hasta la inmovilidad total. La parálisis cerebral es incurable; sin embargo, no es progresiva y muchos síntomas pueden aliviarse con fisioterapia

\section{Síndrome de Down}

Es un trastorno genético en el cual una persona tiene 47 cromosomas en lugar de los 46 usuales en el par 21 que afecta a todas las células del cuerpo. Los síntomas del síndrome de Down varían de una persona a otra y pueden ir de leves a graves. Sin embargo, los niños con síndrome de Down tienen una apariencia característica ampliamente reconocida. La cabeza puede ser más pequeña de lo normal y anormalmente formada. Por ejemplo, la cabeza puede ser redonda con un área plana en la parte de atrás. La esquina interna de los ojos puede ser redondeada en lugar de puntiaguda, dedos rechonchos en manos y pies y pliegues característicos en manos y de los pies, lengua grande.

En general todos los niños tienden a ser bajos, rollizos y tener escaso tono muscular. Algunos pueden tener lesiones cardíacas o intestinales. Todos los niños con este tipo de retraso intelectual tienen dificultades de aprendizaje, pero su grado de afectación varia extraordinariamente y gracias a los controles prenatales de la madre cada vez es menos. 


\section{Sistema Genito - Urinario y Endocrino}

\section{MANEJO DE LA COMPLICACIONES DE LOS TRASTORNOS HIPERTENSIVOS GESTACIONALES}

\section{Hematoma Subscapular Hepático}

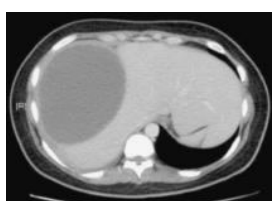

Presencia de sangre libre entre el parénquima hepático y la capsula de Glisson, debido a la confluencia de micro hemorragias provocada por la necrosis hemorrágicas periportal. La rotura del hematoma produce alta morbilidad y mortalidad por el shop hipovolémico subsiguiente.

Diagnóstico de Hematoma Subcapsular Hepático según historia Clínica Perinatal

Anamnesis Diagnostico o sospecha diagnóstica de preeclampsia eclampsia complicada con síndrome de HELLP.

\section{Examen Físico}

I. Persistencia de dolor epigástrico $\circ$ en abdomen superior a pesar del tratamiento con sulfato de magnesio $y$ antihipertensivos

2. Signos de hipovolemia o anemia aguda

3. Pulso rápido y débil ( $110 \times$ min o más)

4. Presión arterial baja (sistólica $0<90 \mathrm{~mm} \mathrm{Hg}$ )

5. Palidez en conjuntivas palmas de las manos y peri bucal

6. Respiración rápida de 30 o más $x$ min

7. Sudoración o piel fría y húmeda

8. Respiración rápida de 30 o más por min.

\section{Exámenes de Laboratorio}

-Visualización de hematoma por imagen: ecografía, TAC, RM.

-Caída del hematocrito- hemoglobina.

-Pruebas de función hepática. 


\section{Sistema Genito - Urinario y Endocrino}

-Protocolo de manejo del hematoma subscapular hepático como complicación de los trastornos hipertensivos gestacionales y síndrome de HELLP.

I. No pierda la calma, piense de manera lógica y concéntrese en las necesidades de la paciente

2. No deje a la paciente desatendida, explique a los familiares y a la paciente del estado de conciencia, cuál es su situación y los pasos a seguir

3. Hágase cargo de la situación, evite confusiones mediante la presencia de una sola persona que comande las acciones

4. Pida ayuda y movilice urgentemente a todo el personal disponible

5. Monitoree los signos vitales (pulso, presión arterial, respiración y temperatura)

6. Coloque a la embarazada del lado izquierdo para reducir al mínimo el riesgo de aspiración en caso de vomito

7. Abrigue a la mujer para evitar el enfriamiento

8. Eleve las piernas para aumentar el retorno venoso (eleve el borde interior de la cama)

9. Si la condición de la paciente es estable y permite realizar ecografía abdominal y hepática donde se confirma diagnóstico de hematoma subcapsular hepático, aplique tratamiento conservador del hematoma.

\section{Coagulación Intravascular Diseminada (CID)}

Trastorno hematológico y sistémico caracterizado por la formación y destrucción acelerada de fibrina, teniendo como etiología alguna patología obstétrica, principalmente, el síndrome de HELLP.

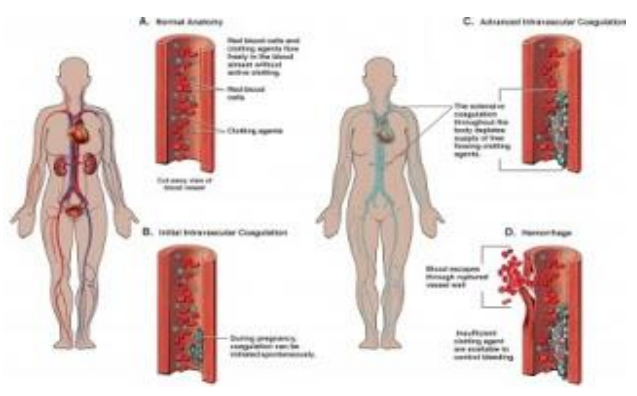




\section{Sistema Genito - Urinario y Endocrino}

\section{Anamnesis}

a. Diagnostico o sospecha diagnóstica de preeclampsia eclampsia complicada con síndrome de HELLP

b. Patología obstétrica de base

c. Preeclampsia

d. Eclampsia

e. Síndrome de HELLP

f. Desprendimiento normo placentario

g. Sangrado tercer periodo

h. Placenta previa.

\section{Examen Físico}

I. Presencia de hematuria

2. Gingivorragia

3. Epistaxis

4. Falta de formación o coagulo inestable.

\section{Edema Agudo de Pulmón}

Paso de líquido desde los capilares pulmonares al espacio alveolar. El desequilibrio entre la presión hidrósfera y la presión incaica del alvéolo determina la presencia de exudado espumoso en el alvéolo que impide la oxigenación normal.

\section{Anamnesis}

Diagnóstico o sospecha diagnóstica de preeclampsia eclampsia complicada con síndrome de HELLP.

\section{Examen Físico}

I. Presencia de disnea grave, generalmente acompañada de tos y de expectoración espumosa rosada

2. Ansiedad, cianosis, taquicardia y taquipnea

3. A la auscultación rales finos húmedos que inician en las bases y tienden a elevarse en los campos pulmonares

4. Sobrecarga de líquidos.

\section{Exámenes de Laboratorio}

I. Oximetría de pulso disminuida 


\section{Sistema Genito - Urinario y Endocrino}

2. Gasometría con acidosis respiratoria y metabólica.

\section{Insuficiencia Renal Aguda}

Representa la interrupción brusca y potencialmente reversible de la función renal, manifestada por anuria.

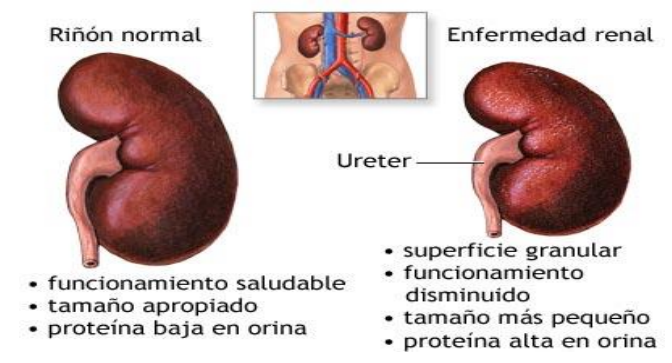

\section{Insuficiencia Pre renal}

Causada por hipovolemia (deshidratación o depleción de sodio o anemia aguda) reversible si se mejora a la percusión renal.

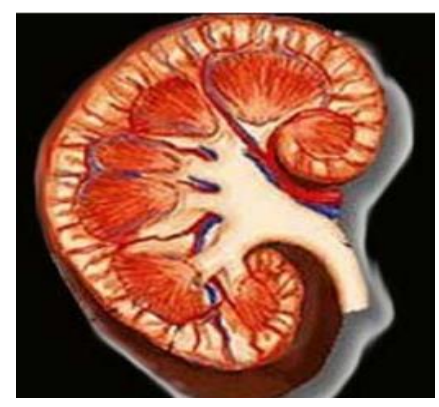

\section{Insuficiencia Renal}

-Verdadera insuficiencia del parénquima renal

-Necrosis tubular aguda, frecuente, reversible en relación al número de nefronas comprometidas

-Necrosis cortical aguda, menos frecuente, y reversible si es bilateral. 


\section{Sistema Genito - Urinario y Endocrino}

\section{Insuficiencia Pos renal}

-Obstrucción del tracto urinario más allá del glomérulo (calculo enclavado, ligadura del uréter, etc)

-Reversible en función de la duración y de la corrección rápida de la obstrucción

-Transmisión sexual, pero a veces se transmite al recién nacido durante el parto cuando desciende por el canal de una mujer infectada. En los bebés cuando hay gonorrea puede causar una infección ocular que en ocasiones provoca ceguera.

-La gonorrea está más extendida entre aquellos adultos que tiene varios compañeros sexuales, en particular, en edades comprendidas entre 15 y 25 años. Aproximadamente, el $40 \%$ de la mujeres y algunos hombres no presentan ningún síntoma hasta que la enfermedad ha progresado y se encuentra en un estado bastante avanzado. En los hombres, los síntomas suelen ser inflación a la uretra, con pus y dolor agudo durante la micción. La próstata y el epidídimo también puede ser afectado. Los síntomas en las mujeres suele ser flujo vaginal, sensación de ardor durante la micción y dolor en el bajo vientre.

\section{BIBLIOGRAFÍA SUGERIDA}

1. Carusi D. Pregnancy of unknown location: Evaluation and management. Semin doi:10.1053/j.semperi.2018.12.006

2. Holness N. High-Risk Pregnancy. Nurs Clin North Am. 2018;53(2):241-251. doi:10.1016/j.cnur.2018.01.010

3. Horvath S, Schreiber CA. Unintended Pregnancy, Induced Abortion, and Mental Health. Curr Psychiatry Rep. 2017;19(11):77. Published 2017 Sep 14. doi:10.1007/s11920-017-0832-4

4. Tobasía-Hege C, Pinart M, Madeira S, et al. Irrespeto y maltrato durante el parto y el aborto en América Latina: revisión sistemática y metaanálisis [Disrespect and abuse during childbirth and abortion in Latin America: systematic review and meta-analysisDesrespeito e maus-tratos durante 0 parto e o aborto na América Latina: revisão sistemática e metaanálise]. Rev Panam Salud Publica. 2019;43:e36. Published 2019 May 3. doi:10.26633/RPSP.2019.36 


\section{Sistema Genito - Urinario y Endocrino}

5. Volkov VG, Granatovich NN, Survillo EV, Pichugina LV, Achilgova ZS. Abortion in the Structure of Causes of Maternal Mortality. Aborto na estrutura das causas da mortalidade materna. Rev Bras Ginecol Obstet. 2018;40(6):309-312. doi:10.1055/s-0038-1657765

6. Mota VMR, Cavalcanti LPG, Delfino ADS, Lopes TECF, Pessoa ALS, Ribeiro EM. Abortion in Cases of Zika Virus Congenital Infection. Aborto nos casos de infecção congênita pelo vírus Zika. Rev Bras Ginecol Obstet. 2018;40(7):417-424. doi:10.1055/s-0038-1648219

7. Heerema-McKenney A. Defense and infection of the human placenta. APMIS. 2018;126(7):570-588. doi:10.1111/apm.12847

8. Roberts RM, Green JA, Schulz LC. The evolution of the placenta. Reproduction. 2016;152(5):R179-R189. doi:10.1530/REP-16-0325

9. Martell Claros N. La hipertensión arterial en la embarazada [Gestational hypertension]. Hipertens Riesgo Vasc. 2017;34 Suppl 2:22-25. doi:10.1016/S1889-1837(18)30071-0

10. Wisner K. Gestational Hypertension and Preeclampsia. MCN Am J Matern Child Nurs. 2019;44(3):170. doi:10.1097/NMC.0000000000000523

11. Maheu-Cadotte MA, Pépin C, Lavallée A, et al. CE: Gestational Hypertension, Preeclampsia, and Peripartum Cardiomyopathy: A Clinical Review. Am J Nurs. 2019;119(11):32-40. doi:10.1097/01.NAJ.0000605352.84144.a2

12. Shen M, Smith GN, Rodger M, White RR, Walker MC, Wen SW. Comparison of risk factors and outcomes of gestational hypertension and pre-eclampsia. PLoS One. 2017;12(4):e0175914. Published 2017 Apr 24. doi:10.1371/journal.pone.0175914 
Sistema Genito - Urinario y Endocrino

\section{Capítulo VII}

Métodos anticonceptivos y estirilidad 


\section{Sistema Genito - Urinario y Endocrino}

\section{CAPITULO IX METODOS ANTICONCEPTIVOS}

Un método anticonceptivo es cualquier acto, dispositivo o medicación para impedir una concepción o un embarazo viable. También es llamado anticoncepción o contracepción. Se usa en vistas del control de la natalidad. La planificación, provisión y uso de métodos anticonceptivos es llamado planificación familiar.

Hay varios métodos anticonceptivos. Todos son seguros y efectivos, se adaptan a estilos de vida, etapas de la vida y necesidades diferentes. Por tanto, incluso si lleva años utilizando un anticonceptivo concreto, es normal cambiar de método a medida que experimente cambios en su vida y su cuerpo. Existen muchos tipos de métodos anticonceptivos para elegir. Los principales son:

I. Anticoncepción natural.

2. Anticonceptivos de barrera.

3. Anticonceptivos hormonales.

4. Esterilización.

\section{Anticoncepción natural}

Son métodos que se basan en la abstinencia sexual durante determinados días del ciclo menstrual. En cada ciclo existen numerosos días en los que mantener relaciones sexuales sin protección no dará lugar a un embarazo. Así, la anticoncepción natural requiere determinar cuáles son esos días $y$, por tanto, también cuáles suponen un riesgo de embarazo. Son métodos sin efectos secundarios de los que preocuparse y que no requieren interrumpir las relaciones sexuales. Estos son algunos ejemplos de los diversos tipos de anticoncepción natural:

\section{Coito interrupto o método del retiro}

Durante el coito, el hombre retira el pene de la vagina antes de eyacular. El hombre retira el pene de la vagina antes o cuando siente que ha llegado el punto donde ya no puede 


\section{Sistema Genito - Urinario y Endocrino}

contener la eyaculación. El hombre eyacula fuera de la vagina, teniendo mucho cuidado de que el semen no tenga contacto con la vulva de su pareja.

\section{Monitor de anticoncepción Clearblue}

Es un método anticonceptivo natural. Carece de efectos secundarios, es fácil de usar. Su funcionamiento se basa en el control de los cambios hormonales en la orina para determinar qué días del ciclo menstrual presentan una mayor probabilidad de embarazo, tiene un $94 \%$ de fiabilidad.

\section{Método del ritmo o del calendario}

Algunos métodos anticonceptivos parten del hecho de que la ovulación se produce alrededor del día 14, aunque esto es algo que varía de un ciclo a otro y de una mujer a otra. Requiere anotar precisamente durante algunos meses el inicio de cada ciclo menstrual en un diario para poder calcular cuándo se produce la ovulación y poder así tener cierta idea de los días en que es necesario abstenerse de mantener relaciones sexuales y de los que suponen un riesgo más bajo.

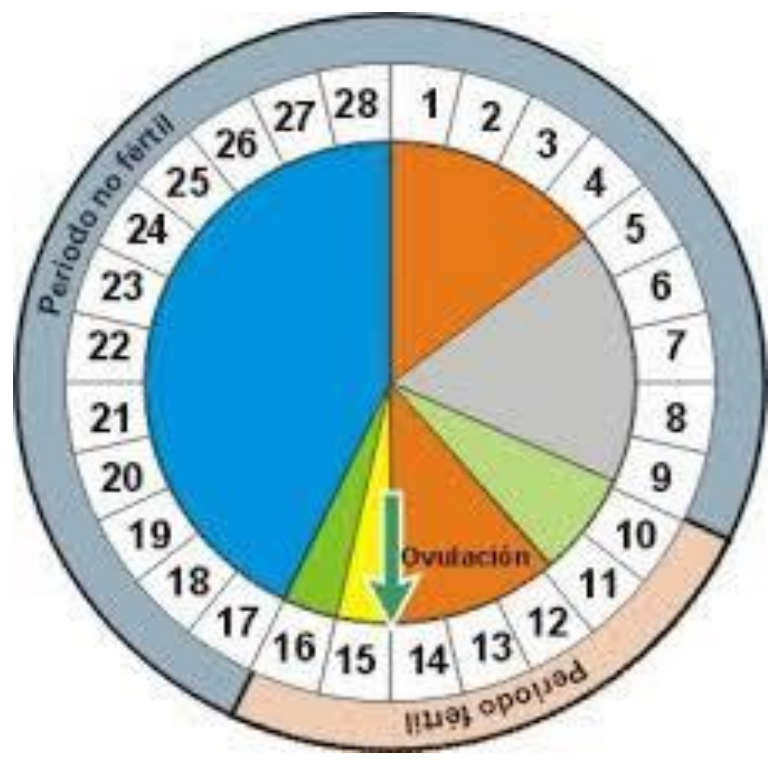




\section{Sistema Genito - Urinario y Endocrino}

\section{Anticonceptivos de barrera}

Son anticonceptivos que impiden la llegada del esperma al óvulo a través de una barrera física.

\section{Preservativo masculino}

I. Hecho de látex fino (también está disponible sin látex).

2. Se coloca sobre el pene en erección antes de las relaciones sexuales.

3. Protege de las ETS.

4. Presenta un $98 \%$ de eficacia si se utiliza correctamente.

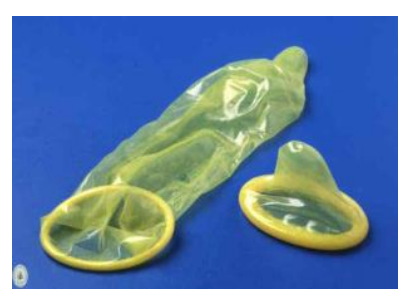

\section{Preservativo femenino}

I. Hecho de poliuretano fino.

2. Se coloca en la vagina antes de mantener relaciones sexuales.

3. Protege de las ETS.

4. Eficacia de hasta el $95 \%$ si se utiliza correctamente. 


\section{Sistema Genito - Urinario y Endocrino}

\section{Diafragma o capuchón cervical}

I. Es un casquete de goma fina.

2. Se coloca en la vagina antes de mantener relaciones sexuales para cubrir el cuello uterino.

3. Puede utilizarse con espermicida (gel o crema que destruye el esperma).

4. Presenta entre un $92 \%$ y un $96 \%$ de eficacia si se utiliza correctamente.

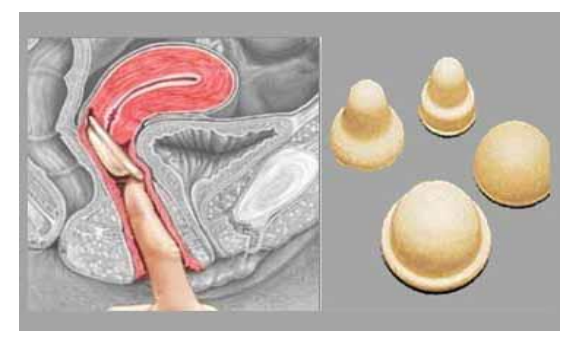

\section{Anticonceptivos hormonales}

Por lo general, son versiones sintéticas de los estrógenos o de la progesterona que alteran los niveles hormonales naturales para impedir que el cuerpo ovule o se prepare para tener un bebé. Son métodos muy fiables si se utilizan correctamente. Algunas mujeres dicen sufrir efectos secundarios indeseados y la píldora puede no ser conveniente para todas las mujeres por motivos médicos.

\section{Píldora anticonceptiva}

\section{Paquete de pastillas de 21 días}

Esta clase de pastillas son combinadas, y se empiezan a tomar el primer día que se tiene la regla, tomando un comprimido cada día a la misma hora, durante los 21 días. Pasados los 2 I días, se descansa durante 7 días, que es cuando tendremos la menstruación, y luego se empieza de nuevo a tomar la pastilla otros 2 I días más y así sucesivamente. La pastilla se deja de tomar cuando se tiene el periodo.

\section{Paquete de pastillas de 28 días}




\section{Sistema Genito - Urinario y Endocrino}

Estas pastillas son de uso diario, son combinadas, y se tienen que tomar todos los días del año a la misma hora, no se tiene que descansar ningún día, ya que el envase es de 28 pastillas. Esta clase de pastillas se toman cada día, ya que las últimas 7 píldoras del envase no son eficaces, por tanto durante esos 7 días tiene que venir la regla. Por lo general, las 7 píldoras ineficaces son de distinto color que las otras. Este tipo de pastillas las utilizan mujeres que se les olvida tomar la píldora, o no cuentan el día de empezar a tomarlas, al tomar la pastilla diariamente sin descanso, cogen el hábito y no se olvidan de tomarla.

\section{Paquete de pastillas para I 2 semanas}

En este caso se tiene que tomar la píldora anticonceptiva cada día a la misma hora, durante 12 semanas seguidas, y luego descansar durante 7 días, que será el periodo en el que tendrá la menstruación. Pasados los 7 días de descanso, se vuelve a tomar la píldora 12 semanas y así sucesivamente. Con este método se disminuye el número de períodos a uno cada 3 meses, en lugar de uno cada mes.

\section{Toma de 24 pastillas anticonceptivas:}

En este caso, el paquete contiene 24 pastillas anticonceptivas, y 4 que no tienen ningún efecto, de otro color para diferenciarlas de las otras. Estas pastillas se toman diariamente a la misma hora durante 24 días, descansando 4 días que será cuando baje la menstruación.

\section{Minipíldora}

I. Se toma durante 28-35 días (dependiendo de la marca), sin descanso.

2. Impide el engrosamiento del endometrio como preparación para el óvulo fecundado.

3. Presenta un $99 \%$ de eficacia si se utiliza correctamente.

\section{Píldora del día después}

Es un anticonceptivo de emergencia al que se puede recurrir cuando falla o no se ha usado un método anticonceptivo planificado en unas relaciones sexuales después de un coito sin protección.

Evita el embarazo, en un alto porcentaje. Se toma la pastilla antes de las 72 horas de haber realizado el acto sexual. A medida de que vaya pasando más tiempo será menos efectiva. 


\section{Sistema Genito - Urinario y Endocrino}

\section{Implantes, inyecciones y parche anticonceptivo}

I. Son anticonceptivos de larga duración.

2. Impiden la ovulación.

3. Hacen que el endometrio no sea receptivo a óvulos fecundados.

4. Hacen que resulte más difícil que los espermatozoides se desplacen por la mucosidad cervical.

5. Eficacia superior al $99 \%$ si se utiliza correctamente.
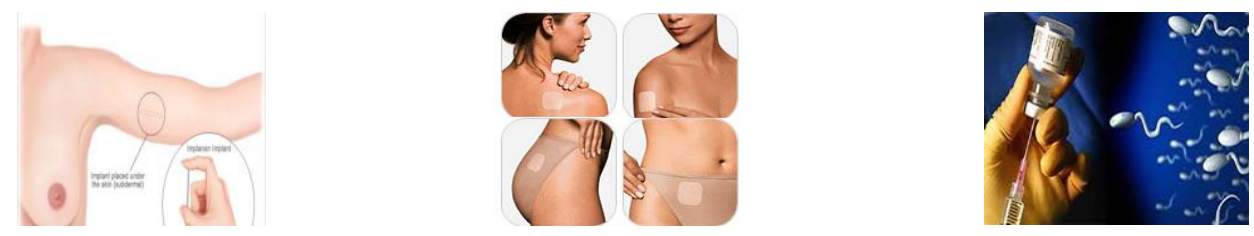

\section{SIU (sistema intrauterino)}

I. Es un anticonceptivo de larga duración.

2. Se trata de un dispositivo en forma de $T$ que se implanta en el útero y contiene una hormona que se libera lentamente.

3. La implantación la realiza el médico y dura 5 años.

4. Hace que el endometrio no sea receptivo a óvulos fecundados.

5. Hace que resulte más difícil que los espermatozoides se desplacen por la mucosidad cervical.

6. Eficacia superior al $99 \%$.

\section{DIU (dispositivo intrauterino)}

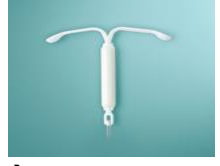

Se parece al SIU en que también lo implanta un profesional sanitario en el útero, pero no contiene hormonas. Crea un entorno donde el esperma no puede fecundar el óvulo.

I. Es un anticonceptivo de larga duración.

2. Se trata de un dispositivo en forma de $T$ que se implanta en el útero. 


\section{Sistema Genito - Urinario y Endocrino}

3. La implantación la realiza el médico y dura entre 5 y 10 años.

4. Impide que los espermatozoides fecunden el óvulo.

5. Los nuevos tipos de DIU presentan una eficacia aproximada del $99 \%$ \%*. Los modelos anteriores son menos eficaces.

\section{Esterilización}

Prevista como anticonceptivo permanente que requiere intervención quirúrgica. Dado que suele ser irreversible, considere esta opción solo si está segura de que no va a desear tener hijos en el futuro.

\section{Esterilización masculina (vasectomía)}

I. Impide el desplazamiento de los espermatozoides desde los testículos al pene.

2. Aproximadamente, I de cada 2000 vasectomías fallan.

\section{Esterilización femenina (ligadura de trompas)}

I. Impide la bajada del óvulo por las trompas de Falopio.

2. Aproximadamente, I de cada 200 esterilizaciones femeninas fallan.

\section{Esterilidad}

\section{Diagnóstico definitivo}

\section{Causas femeninas}

Factor ovárico: Incluye todos aquellos casos en que no se produce la ovulación. Suelen deberse a fallos hormonales ya sea por defecto, o por exceso de alguno de los reguladores de la función endocrina: síndrome de ovario poliquístico (SOP), anovulación, insuficiencia ovárica, menopausia precoz.

Factor tubárico: se incluyen todas aquellas anomalías de las trompas de Falopio que dificultan el encuentro del óvulo y el espermatozoide: ausencia, impermeabilidad u obstrucción de las trompas, salpingitis.

Factor cervical: en este caso, la causa proviene de alteraciones anatómicas y/o funcionales del cuello del útero que interfieren con la correcta migración de los 


\section{Sistema Genito - Urinario y Endocrino}

espermatozoides hacia el útero y las trompas de Falopio en su intento de aproximación al óvulo: impermeabilidad del cuello del útero (pólipos, quistes), cirugía previa (conización).

Factor genético: anomalías cromosómicas que causan abortos espontáneos.

\section{Causas masculinas}

Factor genético: la mayoría se asocian con anomalías del esperma, ya sea directa o indirectamente: fibrosis quística, anomalías del cariotipo como el síndrome de Klinefelter, translocaciones.

En la mayoría de los casos de infertilidad masculina y baja calidad de esperma no hay causas claras que puedan ser identificadas con los métodos de diagnóstico actuales. Se ha especulado que las mutaciones del cromosoma $Y$ pueden ser un factor importante.

Factor anatómico: las obstrucciones de los conductos por donde pasa el esperma pueden causar esterilidad al bloquear parcial o totalmente la salida del líquido seminal. Algunas de estas anomalías pueden ser de origen congénito (presentes al nacer) o adquiridas (infecciones, cicatrices tras intervenciones quirúrgicas del tracto urogenital). Factor ambiental: el estilo de vida puede reducir la cantidad y la calidad espermática (tabaco, alcohol, otras drogas).

Otros tipos de enfermedades: hay enfermedades que pueden aparecer después del nacimiento y pueden influir en la esterilidad masculina: infección por el virus de la parotiditis (paperas), disfunciones hormonales.

\section{Diagnóstico diferencial}

Hipogonadismo hipogonadotropo

Síndrome de Klinefelter

Criptorquidia

Varicocele

Hidrocele

Disgenesia gonadal $X Y$

Mioma 


\section{Sistema Genito - Urinario y Endocrino}

Hipertrofia prostática

\section{BIBLIOGRAFÍA SUGERIDA}

I.

Pritt NM, Norris AH, Berlan ED. Barriers and Facilitators to Adolescents' Use of Long-Acting Reversible Contraceptives. I Pediatr Adolesc Gynecol. 2017;30(I):18-22. doi:I0.1016/j.jpag.2016.07.002

2.

Lortscher D, Admani S, Satur N, Eichenfield LF. Hormonal Contraceptives and Acne: A Retrospective Analysis of 2147 Patients. J Drugs Dermatol. 2016;15(6):670-674.

3.

Robin G, Plouvier P, Delesalle AS, Rolland AL. Contraception hormonale en pratique hors dispositifs intra-utérins. RPC Contraception CNGOF [Effectiveness and use of hormonal contraceptives (except for intrauterine devices): CNGOF Contraception Guidelines]. Gynecol Obstet Fertil Senol. 2018;46(12):845-857. doi:I0.1016/j.gofs.2018.10.003

4.

Hsia IK, Creinin MD. Intrauterine Contraception. Semin Reprod Med. 20 I6;34(3):I75-I82. doi:I0.1055/s0036- I57| 438 
Sistema Genito - Urinario y Endocrino

\section{Capítulo $\mathbf{X}$}

Sistema urinario 


\section{Sistema Genito - Urinario y Endocrino}

\section{CAPITULO VIII SISTEMA URINARIO}

Conjunto de órganos que participan en la formación y evacuación de la orina. Está constituido por dos riñones, órganos densos productores de la orina, de los que surgen sendas pelvis renales como un ancho conducto excretor que al estrecharse se denomina uréter, a través de ambos uréteres la orina alcanza la vejiga urinaria donde se acumula, finalmente, a través de un único conducto como lo es la uretra, la orina se dirige hacia el meato urinario y el exterior del cuerpo.

Los riñones filtran la sangre y producen la orina y se encarga del proceso de osmorregulacion (es la forma activa de regular la presión osmótica del medio interno al cuerpo para mantener la homeostasis de los líquidos del cuerpo; esto evita que el medio interno llegue a estados diluidos o concentrados). El sistema urinario contribuye con la homeostasis mediante la alteración de la composición de la sangre, el pH, el volumen y la presión, el mantenimiento de la osmolaridad de la sangre, la excreción de desechos y sustancias extrañas y la producción de hormonas. Es un conjunto de órganos encargados de la producción y expulsión de la orina. A través de la orina se eliminan del organismo los desechos nitrogenados de metabolismo (urea, creatinina, ácido úrico) y otras sustancias toxicas.

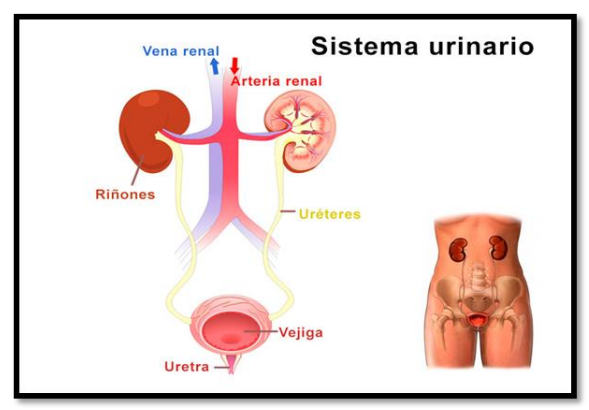




\section{Sistema Genito - Urinario y Endocrino}

\section{Generalidades de las funciones del riñón y su anatomía}

Las funciones de los riñones son las siguientes:

\section{Regulación de la composición iónica de la sangre.}

Los riñones ayudan a regular los niveles plasmáticos de diversos iones

\section{Regulación de la volemia.}

Los riñones regulan la volemia a través de la conservación o la eliminación de agua en la orina.

\section{Regulación de la tensión arterial.}

Los riñones también intervienen en la regulación de la tensión arterial, mediante la secreción de la enzima renina, que activa el sistema renina-angiotensina aldosterona

\section{Mantenimiento de la osmolaridad de la sangre.}

A través de la regulación de la perdida de agua y, por otro sistema, de la pérdida de solutos en la orina, los riñones mantienen la osmolaridad sanguínea relativamente constante alrededor de 300 miliosmoles por litro (mOsm/L) *.

\section{Producción de hormonas.}

Los riñones producen dos hormonas.

\section{Regulación de la glucemia.}

Al igual que el hígado, los riñones pueden utilizar el aminoácido glutamina para la gluconeogénesis, que es la síntesis de nuevas moléculas de glucosa, y luego liberar glucosa hacia la sangre para mantener una glucemia normal

\section{Excreción de desechos y sustancias extrañas.}

Mediante la formación de la orina, los riñones contribuyen a la excreción de desechos, o sea sustancias que no cumplen una función útil en el cuerpo. 


\section{Sistema Genito - Urinario y Endocrino}

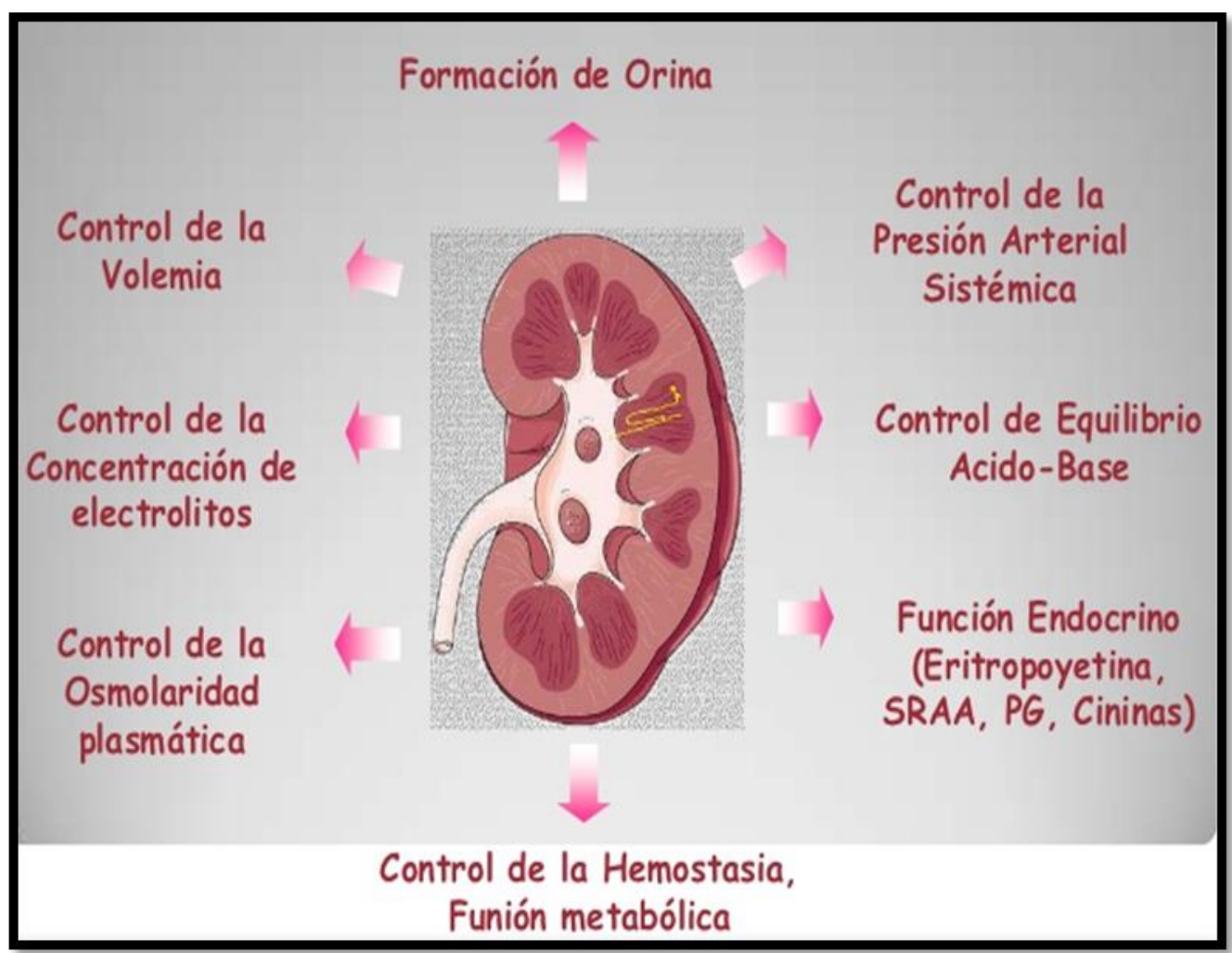

\section{Anatomía externa de los riñones}

Los riñones están situados en el abdomen a ambos lados de la región dorsolumbar de la columna vertebral, aproximadamente entre la $12^{\mathrm{a}}$ vértebra dorsal y la $3^{\mathrm{a}}$ vértebra lumbar, situándose el derecho en un plano inferior al izquierdo, debido a la presencia del hígado. La cara posterior de cada riñón se apoya en la pared abdominal posterior formada por los músculos posas mayor, cuadrado de los lomos y transverso del abdomen de cada lado, su cara anterior está recubierta por el peritoneo, de ahí que se consideren órganos retroperitoneales.

El riñón típico de un adulto mide entre 10 y $12 \mathrm{~cm}$ de longitud (4-5 pulgadas), entre 5 y 7 $\mathrm{cm}$ de ancho (2-3 pulgadas) y $3 \mathrm{~cm}$ de espesor ( $\mathrm{l}$ pulgada), es decir el tamaño aproximado de una barra de jabón de tocador, y pesa entre I 35 y I50 g (4,5-5 onzas). El borde medial cóncavo de cada riñón se orienta hacia la columna vertebral. Cerca del centro de este 


\section{Sistema Genito - Urinario y Endocrino}

borde cóncavo hay una escotadura llamada hilio renal, a través del cual emerge el uréter junto con los vasos sanguíneos, los vasos linfáticos y los nervios.

\section{Morfologia interna: seno, parénquima renal}

\section{(Corteza y médula) y vascularización}

En un corte frontal del riñón observamos dos elementos bien diferenciados: una cavidad llamada seno renal, cuyo orificio es el hilio renal y el tejido llamado parénquima renal. (El parénquima renal es la parte del riñón que asegura sus funciones, está constituido por las nefronas, cada una con una porción en la corteza y otra en la medula renal) que, a su vez, presenta dos zonas de distinto aspecto y coloración: la corteza renal lisa y rojiza, en la periferia y la médula renal de color marrón, situada entre la corteza y el seno renal.

\section{LA NEFRONA}

Al observar microscópicamente el parénquima renal, se constata que cada riñón está constituido por más de I millón de elementos tubulares plegados y ordenados, sustentados por tejido conjuntivo muy vascularizado que denominamos nefronas. En función de la posición en el parénquima se distinguen las nefronas corticales ( $80 \%$ aprox.)

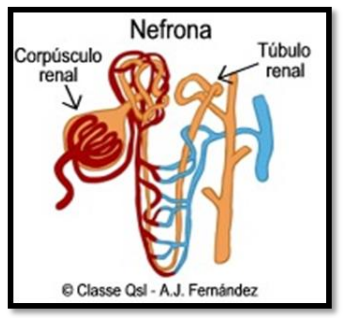
con el corpúsculo situado en la zona más externa de la corteza y el segmento tubular denominado asa de Henle que penetra apenas en la zona superficial de la pirámide medular y las nefronas yuxtamedulares (20\%) que tienen el corpúsculo situado en la zona de la corteza próxima a la médula y el asa de Henle larga que penetra profundamente en la pirámide medular.

Las nefronas son las unidades funcionales de los riñones. Cada nefrona consta de dos partes: un corpúsculo (cuerpo diminuto) renal, donde se filtra el plasma sanguíneo, y un túbulorenal, hacia el que pasa el líquido filtrado. Los dos componentes del corpúsculo renal son el glomérulo (red capilar) y la cápsula glomerular, que es una bolsa epitelial en forma de copa de pared doble, que rodea los capilares glomerulares. El plasma sanguíneo se filtra en la cápsula glomerular y luego el líquido filtrado ingresa en el túbulo renal, el cual tiene tres sectores principales. En el orden en que el líquido 


\section{Sistema Genito - Urinario y Endocrino}

los recorre, estos sectores son: I) el túbulo contorneado proximal, 2) el asa de Henle y 3 ) el túbulo contorneado distal.

I. El túbulo contorneado proximal es un tubo sinuoso de $13 \mathrm{~mm}$ de longitud aprox., se dispone a continuación del corpúsculo renal; consta de un epitelio cuboide simple, cuyas células poseen un borde en cepillo de microvellosidades que aumenta su capacidad de absorción. Su función principal es la de reabsorber el $80 \%$ aprox. del filtrado glomerular.

2. El asa de Henle está constituida por dos ramas en forma de horquilla: la rama descendente que parte a continuación del tubo contorneado proximal y se introduce en la pirámide medular a más o menos profundidad, dependiendo de si se trata de una nefrona cortical o yuxtamedular y la rama ascendente, a continuación, que retorna hacia la corteza renal. En la porción ascendente del asa de Henle de las nefronas yuxtamedulares, se distingue el segmento delgado seguido del segmento grueso; este último presenta un epitelio cuboide simple, a diferencia del resto del asa que se caracteriza por un epitelio escamoso simple. Estas asas largas crean un gradiente de concentración de sodio en el intersticio de la médula renal (mayor concentración salina cuanto más cerca de la papila) que hace posible la formación de escasa orina concentrada cuando el cuerpo necesita ahorrar agua.

3. El túbulo contorneado distal es de epitelio cuboide simple con algunas células principales poseedoras de receptores para las hormonas antidiurética y aldosterona. Este segmento sigue la rama ascendente del asa de Henle y, en su porción inicial, se sitúa entre las arteriolas aferente y eferente. La confluencia de estas tres estructuras, forma el denominado aparato yuxtaglomerular que presenta células muy especializadas reguladoras de la tasa de filtración glomerular

4. El túbulo o conducto colector, es un tubo rectilíneo que se forma por confluencia de los túbulos contorneados distales de varias nefronas, a su vez, varios túbulos colectores confluyen en un conducto papilar que junto con otros similares drena 


\section{Sistema Genito - Urinario y Endocrino}

en un cáliz menor. Estos conductos, se prolongan desde la corteza hasta la papila renal, atravesando en altura toda la pirámide. El colector se asemeja al distal en cuanto al tipo de epitelio que lo constituye, además de las células principales, posee muchas células intercaladas que intervienen en la homeostasis del $\mathrm{pH}$ sanguíneo.

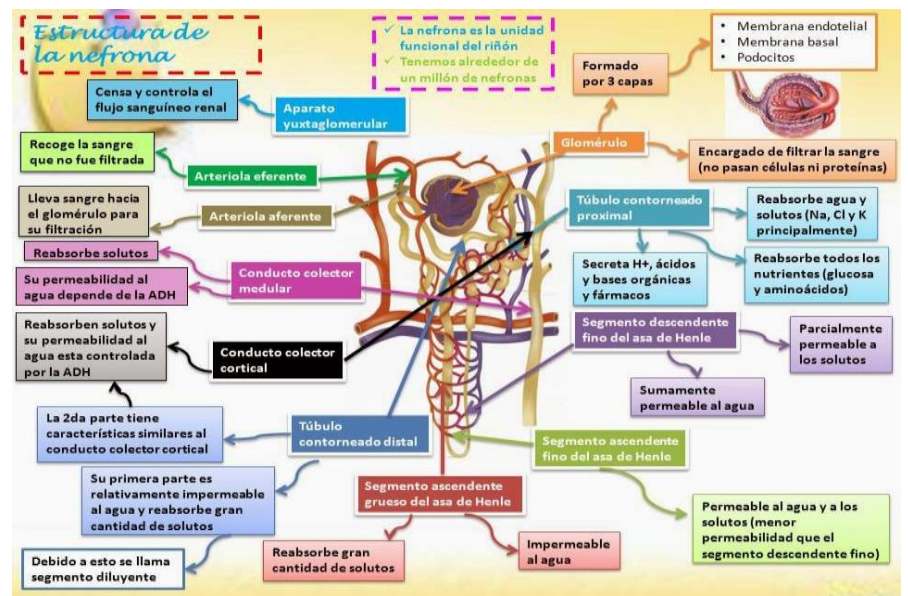

\section{Vías urinarias intrarrenales: cálices y pelvis renal}

Son el conjunto de canales excretores que conducen la orina definitiva desde su salida del parénquima renal hasta el exterior del riñón: los cálices menores y mayores, la pelvis Los cálices menores son unas estructuras visibles macroscópicamente, en forma de copa, situados en el seno Recogen la orina procedente de los conductos papilares que desembocan en la papila renal (vértice agujereado de cada

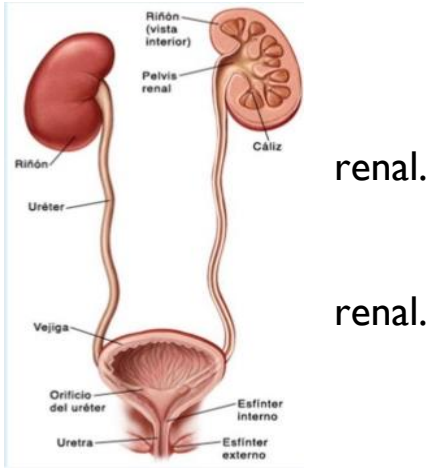
pirámide medular). En cada riñón hay tantos cálices menores como pirámides, es decir entre 8 y 18 aprox. Los cálices mayores, en número de 2 a 3 por riñón, conducen la orina de los cálices menores a la pelvis renal. La pelvis renal se forma por la reunión de los 


\section{Sistema Genito - Urinario y Endocrino}

cálices mayores y es un reservorio con capacidad para 4-8 cm3 de orina, la cual tiene actividad contráctil que contribuye al avance de la orina hacia el exterior. La pelvis renal tiene una porción intrarrenal, situada en el seno renal y una porción extrarrenal, a partir del hilio, que se hace progresivamente más estrecha hasta continuarse con el uréter.

\section{Extrarrenales: uréteres, vejiga y uretra}

Los uréteres miden entre 25 y $30 \mathrm{~cm}$ de largo ( $10-12$ pulgadas), sus paredes son gruesas y su diámetro es pequeño; fluctúa entre I y $10 \mathrm{~mm}$ a lo largo de su trayectoria entre la pelvis renal y la vejiga.

$\mathrm{Al}$ igual que los riñones, los uréteres son retroperitoneales. En la base de la vejiga, los uréteres giran en sentido medial y adoptan una dirección oblicua, a través de la pared vesical posterior.

\section{Uréter}

Los uréteres pasan por debajo de los conductos deferentes, mientas que en la mujer lo hacen por debajo de las arterias uterinas. Finalmente, los dos uréteres llegan al fondo vesical donde se abocan, atraviesan la pared vesical siguiendo un trayecto oblicuo de arriba abajo y de fuera adentro.

La pared de los uréteres consta de tres capas: la mucosa, que recubre la luz del tubo, la muscular intermedia, compuesta por células musculares lisas con actividad contráctil y la serosa externa constituida a base de fibras conjuntivas

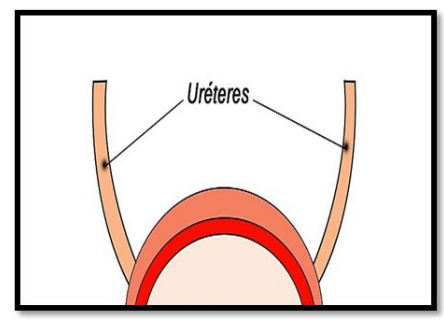




\section{Sistema Genito - Urinario y Endocrino}

\section{Uretra}

La uretra femenina es un conducto de unos $3-4 \mathrm{~cm}$. de longitud destinado exclusivamente a conducir la orina. Nace en la cara inferior de la vejiga, desciende describiendo un

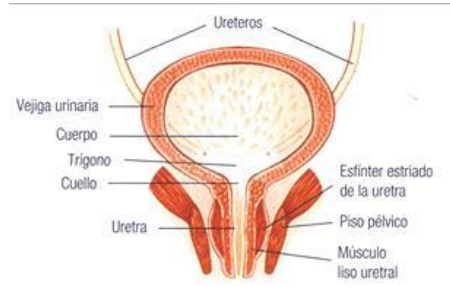
trayecto ligeramente cóncavo hacia delante, entre la sínfisis púbica por delante y la pared vaginal por detrás, desemboca en el meato uretral externo de la vulva, entre el clítoris por delante y el orificio vaginal por detrás. Poco antes del meato, la uretra atraviesa el músculo transverso profundo del periné que constituye su esfínter externo, de control voluntario. La uretra masculina tiene una longitud de entre $20-25 \mathrm{~cm}$ repartidos en varios segmentos:

I. Uretra prostática, segmento de unos $3-4 \mathrm{~cm}$ de longitud y $\mathrm{Icm}$ de diámetro que atraviesa la próstata.

2. Uretra membranosa de $\mathrm{Icm}$ aprox. de longitud, que atraviesa el músculo transverso profundo del periné, el esfínter voluntario del conducto.

3. Uretra esponjosa, que se dispone a todo lo largo del cuerpo esponjoso del pene, hasta el meato uretral.

\section{Vejiga}

Tres capas forman la pared de la vejiga. La más profunda es la mucosa, una membrana compuesta por epitelio de transición y una lámina propia subyacente, similar a la de los uréteres. También hay pliegues que permiten la expansión de la vejiga. Alrededor de la mucosa, se encuentra la túnica muscular, también llamada músculo detrusor (detrusor, que impulsa), formada por tres capas de fibras musculares lisas: la longitudinal interna, la circular media y la longitudinal externa. Alrededor del orificio uretral, las fibras circulares forman el esfínter uretral interno, y más abajo se encuentra el esfínteruretral externo, constituido por musculo esquelético, que se considera una modificación de los músculos profundos del periné. La capa más superficial de la vejiga en las paredes posterior e 


\section{Sistema Genito - Urinario y Endocrino}

inferior es la adventicia, una capa de tejido conectivo areolar continuo con la de los uréteres. En la región superior de la vejiga está la serosa, que es una capa de peritoneo visceral.

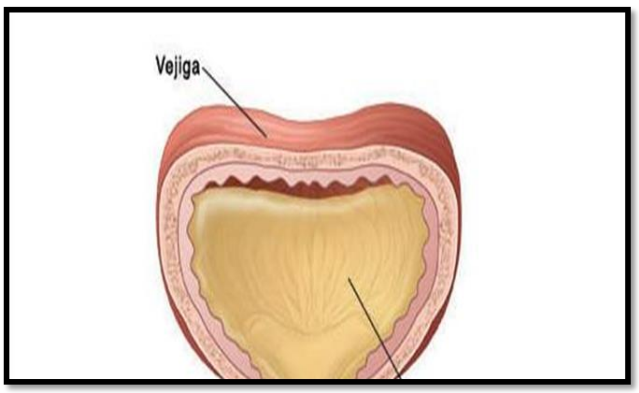

\section{Esfínteres}

Es usualmente un músculo con forma circular o de anillo, que permite el paso de una sustancia de un órgano a otro por medio de un tubo u orificio a la vez que impide su regreso. Existen más de 50 esfínteres diferentes en el cuerpo humano, algunos microscópicamente pequeños en particular, los millones de esfínteres precapilares

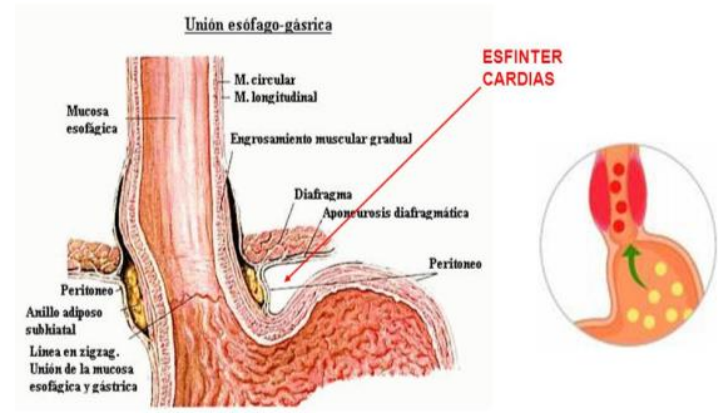

\section{La orina}

La orina es un líquido compuesto por agua y sustancias que el organismo separa y es secretada por los riñones después de la filtración de la sangre. La orina se almacena en la vejiga y se elimina durante la micción.

Olor

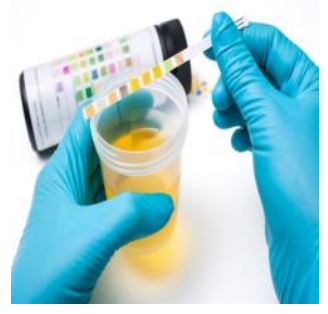




\section{Sistema Genito - Urinario y Endocrino}

Cuando es normal la orina no huele pero en ciertos casos también puede generar un mal olor. El olor inusual puede ser debido o bien a causas benignas y sin importancia (ciertos alimentos, medicamentos) o bien a enfermedades más o menos graves sobre todo las infecciones de orina de la vejiga o de los riñones.

La orina normalmente es estéril, es decir, está desprovista de gérmenes infecciosos. Su colonización por bacterias puede provocar reacciones que provoquen un cierto olor en la orina.

\section{Fisiopatologías del riñón}

\section{Ptosis renal}

La ptosis renal (caída), o riñón flotante, es el desplazamiento hacia abajo o caída del riñón cuando se desliza de su posición normal porque los órganos adyacentes o la cubierta adiposa no lo sostienen en forma adecuada. La ptosis renal se desarrolla más a menudo en personas muy delgadas cuya cápsula de tejido adiposo o la fascia renal es deficiente. Es peligroso porque el uréter puede acodarse y obstruir el flujo de orina. La acumulación de orina resultante ejerce presión sobre el riñón, lo que daña el tejido renal. El acodamiento del uréter también provoca dolor.

La ptosis renal es muy frecuente. Alrededor de I cada 4 personas presenta cierto grado de debilidad en las bandas fibrosas que sostienen al riñón en su lugar. Es 10 veces más común en las mujeres que en los hombres. Como aparece en el transcurso de la vida, resulta muy fácil distinguirla de las malformaciones congénitas.

\section{Cálculos renales}

Los cristales de las sales presentes en la orina precipitan en forma ocasional y se solidifican

para formar concreciones insolubles denominadas cálculos renales (piedras). En general, contienen cristales de oxalato de calcio, ácido úrico o fosfato de calcio. Las situaciones que promueven la formación de cálculos son la ingesta excesiva de calcio, la escasa ingesta de agua, la acidez o la alcalinidad anormal de la orina y la hiperactividad de las glándulas paratiroides. 


\section{Sistema Genito - Urinario y Endocrino}

Cuando un cálculo se aloja en un conducto estrecho, como el uréter, el dolor puede ser muy intenso. La litotricia por onda de choque (lithos-, piedra) es un procedimiento que utiliza ondas de choque de alta energía para desintegrar los cálculos renales y representa un tratamiento alternativo a la extirpación quirúrgica. Luego de localizar los cálculos renales mediante radiología, un instrumento llamado litotritor emite pulsos cortos de ondas sonoras de alta intensidad, que atraviesan una almohadilla llena de agua $\circ$ gel colocada debajo de la espalda. Durante 30 a 60 minutos, 1000 ondas de choque o más pulverizan el cálculo y crean fragmentos pequeños, que pueden eliminarse con la orina.

\section{Fisiopatologías que provoca la filtración glomerular.}

En algunas enfermedades renales, los capilares glomerulares están dañados y se vuelven tan permeables a las proteínas plasmáticas que ingresan en el filtrado glomerular. Como consecuencia, el filtrado ejerce una presión osmótica coloidal que promueve la salida del agua de la sangre. En esta situación, la PFN aumenta, lo que significa que se filtra más líquido. Simultáneamente, desciende la presión osmótica coloidal de la sangre porque se pierden proteínas plasmáticas con la orina. Como se filtra más líquido de los capilares hacia los tejidos de todo el cuerpo que el que retorna por reabsorción, el volumen sanguíneo disminuye y el volumen del líquido intersticial aumenta. Por lo tanto, la pérdida de proteínas plasmáticas en la orina causa edema, que es un volumen de líquido intersticial elevado en forma anormal.

\section{Fisiopatologías provocadas en la reabsorción y secreción tubular.}

El volumen de líquido que entra en los túbulos contorneados proximales en media hora es mayor que el volumen total del plasma sanguíneo porque el índice normal de filtración glomerular es muy alto, parte de este líquido debe retornar de alguna manera al torrente sanguíneo. La reabsorción (el retorno de la mayor parte del agua filtrada y de muchos solutos al torrente sanguíneo) es la segunda función básica de la nefrona y el túbulo colector. Normalmente, cerca del $99 \%$ del agua filtrada se reabsorbe.

La tercera función de las nefronas y los túbulos colectores es la secreción tubular, la transferencia de sustancias desde la sangre y las células tubulares hacia el líquido tubular. 


\section{Sistema Genito - Urinario y Endocrino}

Este proceso elimina cantidades excesivas de ciertas sustancias corporales disueltas, y también mantiene la sangre a un $\mathrm{pH}$ normal y saludable.

\section{Glucosuria}

Cuando la concentración de glucosa de la sangre es superior a los $200 \mathrm{mg} / \mathrm{ml}$, los cotransportadores renales no pueden trabajar lo suficientemente rápido como para reabsorber toda la glucosa que ingresa en el filtrado glomerular. Como resultado, parte de la glucosa permanece en la orina, un fenómeno denominado glucosuria. La causa más común de glucosuria es la diabetes mellitus, en la cual el nivel de glucosa sanguínea puede elevarse bastante más que lo normal porque la actividad de la insulina es deficiente. Existen mutaciones genéticas raras en el cotransportador $\mathrm{Na}$-glucosa renal que reducen mucho su límite (Transporte máximo: Tm) y causan glucosuria. En estos casos, aparece glucosa en la orina a pesar de que el nivel de glucemia es normal. El exceso de glucosa en el filtrado glomerular inhibe la reabsorción de agua en los túbulos renales. Esto lleva al aumento del volumen urinario (poliuria), la disminución del volumen sanguíneo y la deshidratación.

\section{Enfermedad renal poliquística}

La enfermedad renal poliquística (ERP) es uno de los trastornos hereditarios más frecuentes. En la ERP, los túbulos renales presentan cientos o miles de quistes (cavidades llenas de líquido). Además, una falla en la apoptosis (muerte celular programada) de las células de los túbulos que no contienen quistes lleva al deterioro progresivo de la función renal $y$, finalmente, a la insuficiencia renal terminal.

Las personas con esta enfermedad también pueden presentar quistes y apoptosis en el hígado, el páncreas, el bazo y las gónadas: mayor riesgo de aneurismas cerebrales; defectos en las válvulas cardíacas y divertículos colónicos. Por lo general, los síntomas no aparecen hasta la adultez, $y$, en ese momento, los pacientes pueden presentar dolor lumbar, infecciones urinarias, hematuria, hipertensión y tumores abdominales de gran tamaño. El uso de fármacos para restablecer la presión arterial normal, la restricción de proteínas y 


\section{Sistema Genito - Urinario y Endocrino}

sal en la dieta y el control de las infecciones urinarias puede retrasar la progresión hacia la insuficiencia renal.

\section{Fisiopatología provocadas por la producción de orina diluida y concentrada.}

\section{Diuréticos}

Los diuréticos son sustancias que disminuyen la reabsorción renal de agua, y produce diuresis y aumenta el flujo urinario, lo que, a su vez, reduce la volemia. Los diuréticos suelen indicarse para tratar la hipertensión arterial cuando está elevada, ya que la disminución de la volemia, en general, desciende la tensión arterial. Los diuréticos naturales son: la cafeína del café, el té y algunas bebidas gaseosas, que inhiben la secreción de $\mathrm{ADH}$. La mayoría de los diuréticos interfiere en un mecanismo de reabsorción de $\mathrm{Na}+$ filtrado. Por ejemplo, los diuréticos de asa como la furosemida (Lasix) inhiben en forma selectiva los transportadores de $\mathrm{Na}+-\mathrm{K}+-2 \mathrm{Cl}$ - en la rama ascendente gruesa del asa Henle. Los diuréticos tiazídicos, como la clorotiazida (Diuril), actúan en el túbulo contorneado distal, donde promueven la pérdida de $\mathrm{Na}+$ y $\mathrm{Cl}$ - en la orina, por inhibición de los transportadores de $\mathrm{Na}+-\mathrm{Cl}-$.

\section{Infección urinaria}

Debido a la anatomía de nuestro sistema urinario, la orina que se encuentra almacenada en la vejiga es estéril, por lo que no aloja bacterias ni otros microorganismos infecciosos. La uretra, es el conducto que lleva la orina desde la vejiga al exterior, y el recorrido en condiciones normales, también es estéril. Para que se produzca una cistitis, el tracto urinario debe ser invadido por microorganismos.

\section{Fisiopatologías provocadas por el mal funcionamiento renal INSUFICIENCIA RENAL.}

La insuficiencia renal es la disminución o el cese de la filtración glomerular.

En la insuficiencia renal aguda (IRA), los riñones dejan de funcionar en forma abrupta por completo (o casi por completo). La principal característica de la IRA es la supresión del flujo urinario, que comúnmente se manifiesta con oliguria (diuresis diaria entre 50 y 250 


\section{Sistema Genito - Urinario y Endocrino}

$\mathrm{mL}$ ) o anuria (diuresis diaria menor que $50 \mathrm{~mL}$ ). Las causas incluyen hipovolemia (ej., por hemorragia), descenso del gasto cardíaco, lesión de los túbulos renales, cálculos renales, medios de contraste utilizados para visualizar los vasos sanguíneos en angiografías, antiinflamatorios no esteroides y algunos antibióticos. También se desarrolla con frecuencia en pacientes afectados por enfermedades graves o traumatismos masivos, en cuyo caso puede relacionarse con una insuficiencia orgánica más generalizada conocida como síndrome de disfunción multiorgánica.

La insuficiencia renal provoca múltiples trastornos. Se produce edema debido a la retención de agua y sales, y acidosis metabólica, como consecuencia de la incapacidad de los riñones de excretar sustancias ácidas. A nivel de la sangre, se eleva la concentración de urea debido a la alteración de la excreción renal de productos de desecho metabólico y las concentraciones de potasio aumentan, lo que puede ocasionar un paro cardíaco. A menudo hay anemia porque los riñones no producen suficiente eritropoyetina para estimular una producción adecuada de eritrocitos. Dado que los riñones ya no son capaces de convertir la vitamina $D$ en calcitriol, el cual es necesario para la correcta absorción de calcio en el intestino delgado, también puede aparecer osteomalacia.

La insuficiencia renal crónica (IRC) consiste en un descenso progresivo $y$, en general, irreversible de la tasa de filtración glomerular (TFG). Puede deberse a glomerulonefritis crónica, pielonefritis, enfermedad renal poliquística o a la pérdida traumática de tejido renal. La IRC evoluciona en tres estadios. En el primer estadio, que se conoce como disminución de la reserva renal, se destruyen nefronas hasta que se pierden alrededor del $75 \%$ de las nefronas funcionantes.

En este estadio, el paciente puede no presentar signos o síntomas, ya que las nefronas remanentes aumentan de tamaño y compensan la función de las que se perdieron. Una vez que se pierde el $75 \%$ de las nefronas funcionales, el paciente ingresa en el segundo estadio, denominado insuficiencia renal, caracterizado por descenso de la TFG y aumento de la concentración sanguínea de desechos nitrogenados y creatinina. Asimismo, los riñones no pueden concentrar ni diluir la orina. El estadio final, insuficiencia renal terminal, se 


\section{Sistema Genito - Urinario y Endocrino}

produce cuando se pierden cerca del $90 \%$ de las nefronas. En este estadio, la TFG disminuye al $1015 \%$ de su valor normal, aparece oliguria y las concentraciones sanguíneas de desechos nitrogenados y de creatinina aumentan aún más. Las personas con insuficiencia renal terminal requieren diálisis y son posibles candidatos a un trasplante de riñón.

\section{Fisiopatologías del transporte almacenamiento y eliminación de la orina}

Desde los túbulos colectores, la orina drena a través de los cálices menores, los cuales se unen para constituir los cálices mayores, que a su vez confluyen y forman la pelvis renal. Desde la pelvis renal, la orina primero drena en los uréteres y luego en la vejiga, para por último, abandonar el cuerpo a través de la uretra. Las principales fisiopatologías que se dan en el transporte, almacenamiento y eliminación de la orina son:

\section{Incontinencia funcional urinaria}

La falta de control voluntario sobre la micción se llama incontinencia urinaria. En los niños menores de 2 a 3 años de edad, la incontinencia es normal, ya que las neuronas que controlan el esfínter uretral externo no están desarrolladas por completo y la micción tiene lugar cuando la vejiga se encuentra lo suficientemente distendida como para estimular el reflejo miccional. La incontinencia urinaria también puede producirse en los adultos. Hay cuatro tipos de incontinencia urinaria: de esfuerzo, de urgencia, por rebosamiento y funcional.

La incontinencia de esfuerzo es el tipo más común de incontinencia en las mujeres jóvenes y de mediana edad y es el resultado de la debilidad de los músculos profundos del piso de la pelvis. Como consecuencia cualquier episodio de estrés físico que aumente la presión abdominal, como la tos, el estornudo, la risa, el ejercicio, los esfuerzos, el levantamiento de objetos pesados y el embarazo, provoca la pérdida de orina de la vejiga.

La incontinencia de urgencia o apremio es más común en las personas mayores y se caracteriza por la necesidad abrupta e intensa de orinar, seguida por la pérdida involuntaria de orina. Puede deberse a la irritación de la pared de la vejiga, como resultado 


\section{Sistema Genito - Urinario y Endocrino}

de una infección o por cálculos, un accidente cerebrovascular, esclerosis múltiple, lesión de la médula espinal o ansiedad.

La incontinencia por rebosamiento es el goteo involuntario de pequeñas cantidades de orina causado por algún tipo de bloqueo o por contracciones débiles de los músculos de la vejiga. Cuando el flujo urinario está bloqueado (p. ej., en presencia de una próstata agrandada o por cálculos) o cuando los músculos vesicales ya no se pueden contraer, la vejiga se llena en forma excesiva y la presión en su interior aumenta hasta que se escapan pequeñas cantidades de orina al exterior. La incontinencia funcional es la pérdida de orina resultante de la imposibilidad de acudir al cuarto de baño, como resultado de un accidente cerebrovascular, artritis grave o enfermedad de Alzheimer. La elección del tratamiento adecuado depende del diagnóstico correcto del tipo de incontinencia.

\section{Cáncer de vejiga}

Cada año, cerca de 1200 estadounidense muere debido a cáncer de vejiga. En general, afecta a las personas de más de 50 años y es tres veces más frecuente en los varones que en las mujeres. La enfermedad suele evolucionar sin dolor y, en la mayoría de los casos, la hematuria es el primer signo de la enfermedad. Con menor frecuencia, los pacientes experimentan disuria, polaquiuria o ambos. Si la enfermedad se detecta y se trata en forma temprana, el pronóstico es favorable. Por fortuna, cerca del $75 \%$ de estos cánceres está confinado al epitelio de la vejiga y pueden extirparse con facilidad mediante cirugía. Las lesiones tienden a ser de bajo grado de malignidad, es decir, tienen bajo potencial metastásico. Con frecuencia, el cáncer de vejiga se debe a la presencia de un carcinógeno. Cerca de la mitad de los casos se observa en personas que fuman o han fumado cigarrillos alguna vez. También tiende a desarrollarse en personas expuestas a sustancias químicas llamadas aminas aromáticas. Los trabajadores de las industrias del cuero, tinturas, goma y aluminio, así como los pintores, con frecuencia, están expuestos a estas sustancias.

\section{Valores de laboratorio}




\section{Sistema Genito - Urinario y Endocrino}

Cuando disminuye la función renal, ciertas sustancias comienzan a acumularse en el torrente sanguíneo. Los análisis de sangre y orina le ayudan al médico a saber cómo están funcionando los riñones. Los siguientes son análisis comunes que se utilizan para evaluar la función renal:

Tasa de Filtración Glomerular (TFG): este análisis de sangre brinda el mejor valor para indicar cómo están funcionando los riñones. Es como un porcentaje de la función renal. Por ejemplo, una TFG de 30 significa que usted tiene un $30 \%$ de funcionamiento renal normal. La TFG revela la «etapa» de la enfermedad renal. Los valores altos de TFG significan que los riñones están funcionando mejor. Los valores bajos de TFG indican que sus riñones no están funcionando tan bien. Según la TFG hay cinco etapas de enfermedad renal crónica:

Etapa I: la TFG es de 90 o superior. Puede haber una lesión renal leve.

Etapa 2: la TFG es de 60 a 90 . Hay una disminución leve de la función renal.

Etapa 3: la TFG es de 30 a 60. Disminución moderada de la función renal.

Etapa 4: la TFG es de 15 a 30. Hay una disminución grave de la función renal.

Etapa 5: la TFG es de 15 o menos. Se considera enfermedad renal. Se necesita un tratamiento como diálisis o trasplante renal para mantener al paciente con vida.

Para tener una idea precisa de la función de los riñones, es suficiente con realizar un sencillo análisis de sangre con determinación de Urea y creatinina y un análisis de una muestra de orina en la que se valore la presencia de células (glóbulos rojos y leucocitos) y/o proteínas (albumina). Hoy en día, estos 2 tipos de análisis forman parte de la rutina de cualquier estudio analítico.

En este apartado comentaré brevemente el significado de las pruebas analíticas relacionadas con el estudio de la función renal. El objetivo es que usted se informe y entienda el significado de las pruebas que le realizarán, pero de ninguna manera, se pretende que usted pueda tomar decisiones médicas sobre su enfermedad, dado que éstas dependen de un análisis profundo y complejo propio de profesionales con experiencia.

\section{Análisis de sangre}




\section{Sistema Genito - Urinario y Endocrino}

I.- Urea:

La urea es un residuo de la descomposición de las proteínas y, por lo tanto, está directamente relacionada con la cantidad de proteínas que comemos. Normalmente, los riñones filtran la urea de la sangre, pero cuando los riñones no funcionan bien, la cantidad de Urea filtrada es menor y aumenta en la sangre. El nivel normal en sangre es inferior a $40 \mathrm{mg} / \mathrm{dl}$.

El aumento de Urea puede producir malestar digestivo (náuseas y vómitos) y cuando los niveles son muy altos, alteraciones en el nivel de conciencia (uremia). Cuando hay Insuficiencia renal, se disminuye la cantidad de proteínas de la dieta para tener menos síntomas de uremia.

\section{2.- Creatinina:}

La creatinina sérica es un residuo de la masa y actividad muscular. Su nivel en sangre es el dato más objetivo y fiable para conocer cómo funcionan los riñones. De este dato y en base a unas fórmulas en la que se tiene en cuenta la edad, el sexo y el peso, podemos calcular, lo que podríamos decir, el porcentaje de función renal (filtrado glomerular). A medida que la creatinina sube en sangre, vemos que el porcentaje de función renal o filtrada, baja.

El nivel normal en sangre varía según el sexo: Mujeres inferior a $0.96 \mathrm{mg} / \mathrm{dl}$ y varones inferior a $1.3 \mathrm{~m} / \mathrm{dl}$. A veces, si se ha hecho un ejercicio intenso las horas antes de hacerse el análisis de sangre, podemos encontrarnos con ligeros aumentos de creatinina que no se corresponden con una insuficiencia renal, sino que es un reflejo de la actividad muscular.

3.- Filtrado glomerular (FG):

Hasta hace poco tiempo, la función renal se calculaba mediante el cálculo del Aclaramiento de Creatinina, para lo que era necesario recoger la orina de todo el día anterior. Cuando esta orina no se recogía bien, los resultados no eran fiables. Actualmente, la recogida de orina de todo el día se obvia, al ser suficiente con disponer de la Creatinina en sangre que junto a la edad, sexo y peso corporal según los casos se obtiene un dato en mililitros 


\section{Sistema Genito - Urinario y Endocrino}

minuto, reflejo de lo que podemos decir es el porcentaje de función renal. Las fórmulas más frecuentemente utilizadas son:

\section{-Ecuación de Cockroft-Gault}

FG: ( 140 -edad) $\times$ peso/72 $\times$ creatinina plasmática

-MDRD (Modification of diet in renal disease)

FG: $186 \times$ creatinina plasmática - I,I $54 \times$ edad - 0,203 x 0,742 (si es mujer) x I,2I (si es raza negra)

Dependiendo del nivel de filtrado que resulte en la fórmula, podemos establecer el grado de Insuficiencia renal del siguiente modo:

$\begin{array}{cc}\text { GRADO IRC } & \text { MDRD }(\mathrm{ml} / \mathrm{min}) \\ \text { I } & >90 \\ \text { II } & 60-90 \\ \text { III } & 30-60 \\ \text { IV } & 15-30 \\ \text { V } & <\end{array}$

Pequeños aumentos de Creatinina en la sangre, puede dar lugar a filtrados de 60 a 100 $\mathrm{ml} / \mathrm{min}$ y, por lo tanto, a efectos prácticos en clínica, sólo se tiene en cuenta cuando el filtrado es inferior a $60 \mathrm{ml} / \mathrm{min}$. Por lo general, cuando el filtrado de sus riñones es inferior a $30 \mathrm{ml} / \mathrm{min}$, debe ser remitido al Nefrólogo, que es el médico especialista que estudia, controla y trata la insuficiencia renal y las enfermedades que la producen.

\section{3.- Potasio:}

El potasio es un mineral que hay en su sangre que ayuda a que su corazón y sus músculos trabajen apropiadamente. Procede fundamentalmente de la dieta (frutas y verduras, chocolate, frutos secos etc.).

Debe mantenerse en unos niveles muy estrictos $(3.5-5.5 \mathrm{meq} / \mathrm{l})$ porque su aumento o disminución, aunque sea leve, puede producir graves alteraciones en nuestro organismo, fundamentalmente, el corazón. Cuando no funcionan bien los riñones, este mineral se elimina menos por la orina $y$, por tanto, aumenta en la sangre, pudiendo llegar a niveles 


\section{Sistema Genito - Urinario y Endocrino}

peligrosos.

Por eso cuando hay insuficiencia renal, siempre se recomienda tomar máximo 2 piezas de fruta (pera o manzana) y cocer la verdura 2 veces, desechando el agua. Si con una dieta cuidadosa no se consigue mantener el potasio en unos niveles adecuados, se suele asociar medicamentos quelantes, que disminuyen su absorción en el intestino.

4.- Albúmina sérica:

La albúmina es la proteína más abundante del plasma sanguíneo, es decir, lo que quedaría de la sangre cuando quitamos todas las células (glóbulos rojos, glóbulos blancos y plaquetas). Se produce en el hígado y tiene muchas funciones, como transportar distintas sustancias por todo el organismo (hormonas, vitaminas, medicamentos, enzimas e iones como el calcio), controla la salida y entrada de líquido de los vasos sanguíneos, es un buen indicador de nuestro estado global de nutrición.

Se consideran valores normales, entre 3,5 y 5,0 gramos por decilitro. Cuando los niveles son bajos, suelen aparecer edemas. Un nivel bajo de albúmina en su sangre puede deberse a que no consume suficientes proteínas en su dieta, que su hígado no la forma correctamente o que sus riñones tienen una enfermedad que favorece su pérdida por orina en grandes cantidades.

5.- Albuminuria:

La albuminuria es la presencia de cierta cantidad de albúmina en la orina, se detecta mediante un análisis de orina de 24 horas o en una muestra de orina y relacionándola la creatinina en orina, mediante el cociente Albumina/Creatinina. Normalmente, la albúmina se encuentra en la sangre y su presencia en orina puede ser normal cuando es inferior a $30 \mathrm{mg} / \mathrm{dl}$ al día; entre 30 a $299 \mathrm{mg} / \mathrm{dl}$ se considera microalbuminuria y ya indica un daño renal incipiente aunque aún no exista síntomas o refleja una enfermedad vascular generalizada.

6.- Calcio:

Los valores normales oscilan de $8.5-10.8 \mathrm{mg} / \mathrm{dl}$. Estos niveles están mantenidos por un complejísimo mecanismo en el que participan otros minerales, hormonas 


\section{Sistema Genito - Urinario y Endocrino}

(Paratohormona), vitamina D etc. Cuando no funcionan bien los riñones, este mecanismo se desequilibra y, finalmente, se produce una alteración en la cantidad y calidad del hueso. 7.- Fósforo:

Los niveles óptimos están $3.5-5 \mathrm{mg} / \mathrm{dl}$ y en insuficiencia renal se sabe que es importantísimo y, a veces, muy difícil mantenerlos. Un nivel alto de fósforo puede provocar huesos débiles, y tiene un efecto negativo sobre todo el sistema cardiovascular. En insuficiencia renal, el control de los niveles de fósforo es muy difícil, dado que está presente en la mayor parte de los alimentos que tomamos, desde lácteos (leche, yogurt, queso), proteínas, salsas y condimentos, integrales etc. Por ello, cuando una dieta cuidadosa no es capaz de mantener los niveles correctamente, se dan medicamentos para disminuir la absorción del intestino, son los llamados quelantes y que se toman siempre con las comidas.

8.- Hormona paratiroidea (PTH):

La PTH es producida por las glándulas paratiroides que se encuentran en el cuello a los lados del tiroides. La función de la PTH es controlar en un rango muy estrecho, los niveles de calcio en la sangre. Esta hormona puede aumentar en sangre por 2 circunstancias, una enfermedad propia de la glándula (Hiperparatiroidismo Primario) o por un estímulo externo continuo, fundamentalmente, que el calcio en la sangre esté bajo o el fósforo esté alto (Hiperparatiroidismo secundario). Esta segunda circunstancia es la típica que se da en la Insuficiencia renal. La consecuencia de esta mayor función es la formación de un hueso de peor calidad. También produce un Hiperparatiroidismo secundario problemas intestinales que disminuyen la absorción intestinal de calcio y vitamina $D$, etc. El tratamiento es complejo e individual $y$, totalmente, orientado a la causa que lo ha producido.

\section{9.- Vitamina D:}

Es una Vitamina que obtenemos de 2 fuentes: la irradiación solar y la dieta. A partir de estas 2 fuentes se forma una vitamina $D$ no activa en el hígado, que se activa al pasar por el riñón. Los niveles en sangre óptimos están por encima de $30 \mathrm{ng} / \mathrm{ml}$, pero pueden ser 


\section{Sistema Genito - Urinario y Endocrino}

suficientes por encima de $20 \mathrm{ng} / \mathrm{ml}$; se habla de deficiencia cuando los niveles están por debajo de $10 \mathrm{ng} / \mathrm{ml}$. Hoy en día, por razones que no están bien explicadas, un porcentaje importante de la población (incluso en lugares con mucho sol) tiene niveles bajos de la vitamina $D$ inactiva $y$, por tanto, tendrá menos Vitamina $D$ activa. Las consecuencias de este déficit son múltiples, las más conocidas son las relacionadas con la formación de huesos débiles (raquitismo en los niños). Pero la Vitamina $D$ tiene funciones a otros muchos niveles: inmunidad, protege de ciertos tumores (colon), protege del envejecimiento vasos sanguíneos etc.

\section{0.- Colesterol:}

- Colesterol total: es un tipo de grasa que se encuentra presente en su sangre. Gran parte es producido por nuestro propio organismo y una parte también se absorbe a través de las grasas de origen animal de la dieta. Un nivel alto de colesterol puede aumentar sus probabilidades de tener problemas cardíacos y circulatorios. Los valores recomendables de colesterol total varían en base a sus enfermedades y su riesgo cardiovascular (porcentaje de riesgo de padecer una enfermedad cardiovascular en 10 años, como los infartos). Para muchos pacientes, un nivel bueno de colesterol total se recomienda que sea inferior a 200. Si el nivel de su colesterol es demasiado elevado, es posible que su médico le pida que modifique su dieta, que aumente su nivel de actividad física y que adelgace si es que está con sobrepeso. En algunos casos, si con esto no es suficiente, necesitará además tomar medicamentos.

- Colesterol HDL: El colesterol HDL es el llamado “colesterol bueno”, que protege su corazón y a medida que es más alto disminuye el riesgo cardiovascular (como los infartos). Los niveles normales son por encima de $35 \mathrm{mg} / \mathrm{dl}$. Ayuda a transportar el colesterol desde las arterias hasta el hígado. Se eleva con el ejercicio físico, la dieta con aceite de oliva virgen y el vino tinto en pequeña cantidad. No existen medicamentos claramente eficaces para aumentar sus niveles.

- Colesterol LDL: El colesterol LDL es el llamado colesterol "malo". Un nivel alto de LDL puede aumentar sus probabilidades de tener problemas cardíacos y circulatorios. El nivel 


\section{Sistema Genito - Urinario y Endocrino}

de colesterol LDL recomendable varía en cada paciente en relación a su riesgo cardiovascular (porcentaje de posibilidades de padecer una enfermedad cardiovascular a los 10 años). Para muchos pacientes, el nivel ideal de colesterol LDL es inferior a 100 o incluso $80 \mathrm{mg} / \mathrm{dl}$. Si su nivel de LDL es demasiado elevado, es posible que su médico le pida que modifique su dieta, su nivel de actividad física y adelgace si está con sobrepeso. Si con estas medidas no se alcanza el nivel óptimo, será necesario tomar medicación para reducir sus niveles.

I I.- Triglicéridos:

Los triglicéridos son un tipo de grasa que se encuentra en su organismo y que proviene de los alimentos, fundamentalmente dulces y alcohol. En la Diabetes mal controlada es muy frecuente que estén altos. Un nivel alto de triglicéridos junto con niveles altos de colesterol total y colesterol LDL pueden aumentar sus probabilidades de tener problemas cardíacos y circulatorios. Los valores normales son hasta $200 \mathrm{mg} / \mathrm{dL}$.

12.- Hematocrito y Hemoglobina:

El hematocrito es la concentración de los glóbulos rojos que tiene en la sangre (en $100 \mathrm{ml}$ y por eso se da en porcentaje). La Hemoglobina es la proteína que compone el glóbulo rojo y es la que lleva el oxígeno de sus pulmones a todas las partes de su cuerpo. Un hematocrito y una Hemoglobina baja pueden significar que usted tiene anemia por pérdidas o por falta de hierro, de vitamina B o ácido fólico. Una Hemoglobina baja es normal en el embarazo. Los valores normales:

-Hombre: Hematocrito 40,7 - 50,3\% y Hemoglobina 13.8 a 17.2 gr/dl

-Mujer: 36,I - 44,3\% y Hemoglobina 12.1 a 15.1 gr/dl

Cuando hay Insuficiencia renal, además de las anteriores causas, está la menor formación de Eritropoyetina (EPO) que estimula la fabricación de glóbulos rojos. Al haber menos cantidad de EPO, se forman menos glóbulos rojos. Los síntomas más frecuentes de la anemia son palidez, cansancio, mareo y sensación de poca energía. El objetivo del tratamiento es dar aquello de lo que carecemos (hierro, vitamina BI2, ácido fólico, 


\section{Sistema Genito - Urinario y Endocrino}

eritropoyetina). En insuficiencia renal, se consideran niveles de Hemoglobina adecuados de $12-13 \mathrm{gr} / \mathrm{dl}$.

\section{3.- Glóbulos Blancos:}

Los glóbulos blancos o leucocitos son las células de la sangre que forman parte de la inmunidad. Intervienen en la defensa del organismo contra sustancias extrañas e infecciones. Se producen en la médula ósea y en los ganglios linfáticos. Existen 5 tipos de glóbulos blancos: los neutrófilos, los linfocitos, los monocitos, los eosinófilos y los basófilos. Cada uno tiene una función diferente dentro del sistema inmunológico. Por ejemplo, los neutrófilos tienen como misión el control de las infecciones bacterianas, los linfocitos contra las infecciones víricas y los eosinófilos actúan contra los parásitos y también participan en los mecanismos de la alergia. Los valores normales son entre 4.500 y 11.000 por $\mathrm{mm} 3$.

\section{BIBLIOGRAFÍA SUGERIDA}

I. Didier RA, Chow JS, Kwatra NS, Retik AB, Lebowitz RL. The duplicated collecting system of the urinary tract: embryology, imaging appearances and clinical considerations. Pediatr Radiol. 2017;47(II):I526-I538. doi: 10.1007/s00247-017-3904-z

2. Cięszczyk K, Puderecki M, Wronecki L, Burdan F, Szumiło J. Malakoplakia of the urinary system. Folia Med Cracov. 2019;59(2):67-74.

3. Savic S, Vlajnic T, Bubendorf L. Das Paris-System zur Klassifikation der Urinzytologie [The Paris system for classification of urinary cytology]. Pathologe. 20 I7;38(5):45 I-462. doi:I 0.1007/s00292-0 I7-0325-6

4.

Chung EM, Soderlund KA, Fagen KE. Imaging of the Pediatric Urinary System. Radiol Clin North Am. 2017;55(2):337-357. doi:10.1016/j.rcl.2016.10.010 
Sistema Genito - Urinario y Endocrino

\section{Capítulo IX}

\section{Enfermedades renales}




\section{Sistema Genito - Urinario y Endocrino}

\section{CAPITULO XI \\ ENFERMEDADES RENALES}

Aproximadamente el 10\% de la población mundial presenta algún grado de enfermedad renal; desafortunadamente, pasa desapercibida debido a que sus síntomas se presentan en forma muy tardía. Sus principales factores de riesgo para desarrollarla, como la hipertensión arterial, la diabetes, la obesidad, la historia familiar de enfermedad renal y la edad mayor de 60 años, son muy prevalentes a nivel global.

Debido a su alto costo, las terapias de reemplazo de la falla renal, como la diálisis y el trasplante renal, son inaccesibles para la mayoría de la población, especialmente en países en vías desarrollo. De ahí la importancia de detectar la enfermedad renal en forma oportuna y establecer medidas terapéuticas para retardar su progresión. La enfermedad renal puede prevenirse si se detecta a tiempo. Un examen de creatinina en sangre, así como una examen para detectar proteína en la orina son suficientes para detectar su presencia.

\section{Introducción}

El riñón es un órgano extraordinario que mantiene nuestro organismo limpio y saludable mediante la eliminación de substancias tóxicas de deshecho. Aunque su función principal es la de excretar toxinas de nuestro organismo, esta no es la única función.

El riñón juega también un papel muy importante en la regulación de la presión arterial, así como en el volumen y composición de los líquidos corporales. Aunque la mayoría de nosotros nacemos con dos riñones, uno solo basta para efectuar todas estas funciones.

\section{El riñón y sus funciones}

El riñón está entre los órganos más vitales del cuerpo humano. Si no funciona pude llevar a enfermar seriamente $o$ incluso la muerte. Tiene una estructura y funciones complejas. Sus dos funciones más importantes son eliminar productos de desecho, que son tóxicos y peligrosos, así como mantener el equilibrio del agua, fluido, químico y mineral. 


\section{Sistema Genito - Urinario y Endocrino}

\section{Estructura del riñón}

Los riñones producen orina removiendo del cuerpo productos de desecho toxico y el exceso de agua. La orina formada en los riñones pasa por el uréter, fluye hacia la vejiga antes de ser excretada, finalmente, a través de la uretra.

I. La mayoría de la gente (hombres y mujeres) tiene dos riñones.

2. Los riñones están localizados arriba y detrás del abdomen, a cada lado de la columna (ver diagrama). Se encuentran protegidos por las costillas inferiores.

3. Los riñones están muy dentro del abdomen por lo que normalmente no podemos sentirlos.

4. Los riñones son un par de órganos en forma de frijol. En los adultos miden aproximadamente $10 \mathrm{~cm}$ de longitud, $6 \mathrm{~cm}$ de ancho y $4 \mathrm{~cm}$ de grosor. Pesan aproximadamente $150-170 \mathrm{gr}$.

5. La orina formada por los riñones fluye hacia la vejiga urinaria a través de los uréteres. El uréter es una estructura en forma de tubo hueco de unos $25 \mathrm{~cm}$ de longitud hecha de músculos especiales.

6. La vejiga urinaria es un órgano hueco hecho de músculo que se encuentra en la parte baja y delantera del abdomen. Actúa como reservorio de orina.

7. La vejiga en un adulto puede guardar alrededor de 400-500 $\mathrm{ml}$ de orina y cuando se llena cerca de su máxima capacidad, la persona siente la urgencia de dejar pasar la orina.

8. La orina en la vejiga se excreta a través de la uretra durante la micción. En las mujeres la uretra es más bien corta, mientras que en los hombres es mucho más larga.

9. La localización, estructura y funciones de los riñones es la misma en hombres y mujeres.

\section{¿Por qué es el riñón esencial para el cuerpo?}

I. Consumimos diferente cantidad y tipos de comida cada día.

2. La cantidad de agua, sales, y ácidos en nuestro cuerpo también varían cada día. 


\section{Sistema Genito - Urinario y Endocrino}

3. El proceso continuo de convertir comida en energía produce materiales tóxicos peligrosos.

4. Estos factores llevan a cambios en la cantidad de fluidos, electrólitos y ácidos en el cuerpo. Esta acumulación de materiales tóxicos indeseados puede poner en riesgo la vida.

5. Los riñones cargan con el trabajo de limpieza extremadamente esencial de remover ácidos peligrosos y venenosos así como productos tóxicos.

\section{Funciones del riñón}

La principal función del riñón es producir orina y purificar la sangre. El riñón remueve materiales de desecho, sales extras y otros químicos que no requiere el cuerpo. Funciones importantes del riñón se describen a continuación:

\section{Remoción de productos de desecho :}

La purificación de la sangre a través de la remoción de productos de desecho es la función más importante del riñón. La comida que consumimos contiene proteínas. La proteína es necesaria para el crecimiento y reparación del cuerpo. Pero conforme se utilizan proteínas por el cuerpo se generan productos de desecho. La acumulación de estos productos de desecho puede ser venenoso para el cuerpo. El riñón filtra la sangre, y los productos de desecho son excretados en la orina.

\section{Remoción del exceso de fluido:}

La segunda función más importante del riñón es la regulación del balance de fluidos al excretar cantidades extra de agua en forma de orina y reteniendo la cantidad necesaria de agua en el cuerpo. Por lo tanto, los riñones mantienen en el cuerpo la cantidad adecuada de agua. Cuando los riñones fallan, pierden la habilidad para remover el exceso de agua en forma de orina. El exceso de agua en el cuerpo lleva a hinchazón.

\section{Balance de minerales y químicos:}

El riñón juega otro rol importante al regular minerales y químicos como el sodio, potasio, hidrógeno, calcio, fósforo, magnesio y bicarbonato; y al mantener la composición normal del fluido corporal. Cambios en los niveles de sodio pueden afectar a nivel sensorial, 


\section{Sistema Genito - Urinario y Endocrino}

mientras que cambios en el potasio pueden llevar a efectos serios sobre el ritmo del corazón y la función de los músculos. El mantenimiento del nivel normal de calcio y fósforo es esencial para la salud de los huesos y dientes.

\section{Control de la presión arterial:}

El riñón produce diferentes hormonas (renina, angiotensina, aldosterona, prostaglandinas, etc.) y regula el agua y las sales del cuerpo, lo que juega un papel vital en el control de la presión arterial. Alteraciones en la producción hormonal y regulación de sales y agua en un paciente con insuficiencia renal, causa hipertensión arterial

\section{Producción de glóbulos rojos:}

La eritropoyetina producida en el riñón, juega un rol importante en la producción de glóbulos rojos. En la insuficiencia renal la producción de eritropoyetina es menor, lo que conduce a una producción disminuida de glóbulos rojos resultando en hemoglobina baja (anemia). Debido a la baja producción de eritropoyetina en los pacientes con insuficiencia renal, el conteo de hemoglobina no mejora a pesar de suplementar con hierro y vitaminas.

\section{Mantener los huesos sanos:}

El riñón convierte a la vitamina $D$ a su forma activa, la cual es esencial para la absorción del calcio de los alimentos, crecimiento de los huesos y dientes, y mantener sanos a los huesos. En la insuficiencia renal, debido a disminución de la vitamina $D$ activa, el crecimiento de los huesos es reducido y también se vuelven débiles. El retraso en el crecimiento puede ser el primer signo de insuficiencia renal en los niños.

\section{Formación de la orina}

En el proceso de la purificación sanguínea el riñón retiene todas las sustancias necesarias y de forma selectiva excreta fluido extra, minerales y productos de desecho. Déjanos explicar este asombroso y complejo proceso de la formación de orina.

I. Sabías que cada minuto entran en los riñones $1200 \mathrm{ml}$ de sangre para ser purificados, eso es $\mathbf{2 0 \%}$ del total de la sangre bombeada por el corazón. Por lo que en un día se purifican 1700 litros de sangre.

2. Este proceso ocurre en pequeñas unidades de filtro conocidas como nefronas. 


\section{Sistema Genito - Urinario y Endocrino}

3. Cada riñón tiene aproximadamente un millón de nefronas. Cada nefrona está hecha de glomérulos y túbulos.

4. Los glomérulos son filtros con poros muy pequeños con la característica de la filtración selectiva. El agua y las sustancias de pequeño tamaño son fácilmente filtradas a través de ellos. Pero los glóbulos rojos de gran tamaño, glóbulos blancos, plaquetas, proteínas, etc. no pueden pasar a través de estos poros. Por lo tanto, en la orina de una persona sana, las sustancias de gran tamaño están ausentes.

5. El primer paso en la formación de la orina ocurre en el glomérulo, donde $125 \mathrm{ml}$ de orina se filtran por minuto. Es bastante sorprendente que en 24 horas se forman I80 litros de orina. ësta contiene no solo productos de desecho, minerales y sustancias toxicas, sino también glucosa y otras sustancias útiles.

6. El riñón lleva a cabo el proceso de reabsorber con gran inteligencia. Cerca de 180 litros de fluido entran en los túbulos, $99 \%$ de este fluido es reabsorbido de forma selectiva quedando únicamente $I \%$ del fluido que se excreta en forma de orina.

7. Mediante este proceso inteligente todas las sustancias esenciales y 178 litros de fluido son reabsorbidos en los túbulos y en solamente I-2 litros de agua se excretan productos de desecho, minerales extras y otras sustancias peligrosas.

8. La orina formada en el riñón fluye hacia el uréter, pasa a través de la vejiga urinaria $y$, finalmente, se excreta a través de la uretra.

\section{Insuficiencia renal aguda}

La insuficiencia renal aguda se diagnostica aproximadamente en $5 \%$ de los pacientes hospitalizados. Sus principales causas se relacionan con la alteración del flujo sanguíneo renal, sea por depleción de volumen, baja perfusión renal o por distribución intrarrenal inadecuada y obstrucción del árbol urinario.

El diagnóstico parte de la historia clínica y un buen examen físico que corrobore el estado de volemia del paciente y se complementa con el uso adecuado de los índices urinarios (excreción de sodio y osmolaridad), el uroanálisis y la ecografía renal. 


\section{Sistema Genito - Urinario y Endocrino}

Su tratamiento consiste en una adecuada recuperación del volumen, manejo de los diuréticos, soporte nutricional, conservación del equilibrio hidroelectrolítico y brindar terapia de diálisis si hay toxicidad urémica, hipercalcemia severa $(>6.5 \mathrm{mEq} / \mathrm{l})$, acidosis metabólica o sobrecarga severa de volumen.

Los riñones cumplen la misión de mantener el equilibrio hidroelectrolítico y son los órganos mejor irrigados de la economía con $20 \%$ del gasto cardíaco. Poseen un sistema de regulación único, que responde a cambios en el aporte sanguíneo y cambios en el ultra filtrado con disminución en la función.

\section{Clasificación, etiología y fisiopatología}

Para efectos de clasificación y por ser anatómicamente correlacionada, la IRA se clasifica en tres grupos:

\section{Origen prerrenal:}

También se llama hiperazoemia prerrenal, porque se debe a una disminución real o efectiva del volumen circulante, lo que disminuye el flujo sanguíneo renal, desencadena efectos sobre la filtración glomerular, pero las estructuras renales se conservan íntegras. Como la disminución del volumen intravascular (vómito y diarrea), redistribución del volumen (peritonitis, ascitis, sepsis), disminución del gasto cardíaco.

\section{Origen intrarrenal:}

Los mecanismos son múltiples y se relacionan con las estructuras renales:

a) Glomerulares: Hay lesión de tipo inmunológico, con depósitos de complemento, infiltración con células inflamatorias que disminuyen la superficie de filtración y llevan a disminuir el filtrado. Primarias (estreptococo) y secundarias (lupus).

b) Intersticial: Corresponde a fenómeno inflamatorio desencadenado por la presencia de células de la inmunidad y, generalmente, secundario a uso de fármacos, aunque también se puede desencadenar por procesos metabólicos, tóxicos, infecciosos, inmunes e infiltrativos.

c) Necrosis tubular aguda: Se debe a isquemia a nivel tubular ocasionada, generalmente, por redistribución del flujo sanguíneo a nivel cortical/medular, 


\section{Sistema Genito - Urinario y Endocrino}

secundaria a disminución real y severa del volumen circulante, tiene una fase inicial o de establecimiento, una fase de estabilización y una fase de recuperación a la vez; por el volumen urinario se clasifica en oliguria y no oliguria.

d) Vascular: Debida a la interrupción del flujo sanguíneo a nivel de arterias o pequeñas arteriolas, pero que en conjunto impiden la adecuada irrigación al glomérulo.

\section{Origen postrenal.}

Se debe a obstrucción funcional o mecánica del flujo urinario. Como urolitiasis, neoplasias.

\section{Diagnóstico}

\section{Historia clínica:}

El interrogatorio es fundamental y analiza la presencia de enfermedades que soporten el diagnóstico de vasculitis, uso de medicamentos, entidades como cirrosis y enfermedad cardiovascular, pérdida marcada de volumen (vómito, sudoración marcada, diarrea), episodios de hipotensión y diagnóstico previo de enfermedad renal. En el examen físico, además, es necesario descartar la presencia o ausencia de hipovolemia, o signos externos que sugieran diagnóstico de hiperazoemia prerrenal o enfermedad obstructiva. Si el paciente está hospitalizado se debe revisar su historia clínica completa.

\section{Uroanálisis:}

Se encuentra "benigno" en la modalidad prerrenal y obstructiva. En las lesiones renales, se presenta proteinuria, hematuria dismorfa, cilindruria (grasa, hemática y granular), que apoyan el diagnóstico de síndrome nefrótico, glomerulonefritis o necrosis tubular.

\section{3. Índices urinarios:}

El riñón intacto tiene capacidad para reabsorber agua y sal, y concentrar la orina, situación que se altera con la presencia de alteración tubular y se conserva en la hiperazoemia prerrenal. La fracción excretada de sodio es menos de I\% en la hiperazoemia prerrenal y mayor de $1 \%$ en la NTA; la osmolaridad que alcanza hasta 1,200 mosm $/ \mathrm{kg}$ de agua, disminuye alrededor de 300-350 mosm/kg en la NTA. 


\section{Sistema Genito - Urinario y Endocrino}

\section{Ayudas de imagenología:}

La ecografía renal se constituye en el examen más importante, no invasivo y sin efectos adversos, para excluir la presencia de nefropatía obstructiva. La urografía excretora no se recomienda si hay insuficiencia renal aguda.

\section{Complicaciones}

\section{Sistema cardiovascular:}

Se presentan hasta en $35 \%$ de los casos, siendo más frecuente la sobrecarga de volumen y el edema pulmonar en el enfermo oligúrico. Hoy, rara vez, se observa la peri-carditis.

\section{Complicaciones pulmonares:}

Se encuentran con frecuencia infiltrados pulmonares debidos a edema o infección; sin embargo, no hay que olvidar que existen procesos vasculíticos que comprometen pulmón y riñón.

\section{Complicaciones gastrointestinales:}

Las más frecuentes son náusea, vómito y anorexia; en ocasiones, se encuentran úlceras y gastritis.

\section{Complicaciones neurológicas:}

La letargia, la somnolencia acompañan frecuentemente a la insuficiencia renal; pueden progresar a confusión, desorientación, asterixis, mioclonus, convulsiones y hasta coma.

\section{Complicaciones infecciosas:}

No sólo la septicemia complica la insuficiencia renal, también hay focos urinarios, pulmonares y peritoneales que afectan el curso de la IRA.

\section{Complicaciones endocrinas:}

Se presentan alteraciones en el metabolismo de los iones divalentes, disminución de los niveles de T3 y T4, y niveles altos de pTHi y de angiotensina II.

\section{Desórdenes del metabolismo electrolítico:}




\section{Sistema Genito - Urinario y Endocrino}

Para dar el tratamiento adecuado se debe buscar intencionalmente hipercalcemia, hiponatremia, acidosis metabólica e hiperuricemia. La hipocalcemia y la hiperfosfatemia se pueden presentar en situaciones como la rabdomiólisis.

\section{Tratamiento}

\section{Reanimación:}

El paciente con IRA puede estar enfermo en extremo y ameritar un proceso rápido y cuidadoso de repleción de volumen para impedir el edema pulmonar; en esta misma fase, se descarta la presencia de hipercalcemia $y$, si es posible, se practica el diagnóstico etiológico para dar tratamiento dirigió.

\section{Hiperazoemia prerrenal:}

Se restaura el volumen circulante normal; la velocidad de repleción depende del estado del paciente y de la monitoría continua. En situaciones como la insuficiencia renal en el contexto de enfermedad hepática, el reposo, la restricción de sal y la terapia diurética con espironolactona son útiles; ocasionalmente, la paracentesis con o sin albúmina aportan al tratamiento. En caso de insuficiencia cardíaca, los diuréticos son la piedra angular del tratamiento.

\section{Necrosis tubular aguda:}

El tratamiento es sobre todo de sostenimiento, que brinda soporte nutricional adecuado con restricción del aporte proteico y un promedio calórico de 35-40 Kcal/kg, y mantiene el equilibrio hidroelectrolítico; el uso de diuréticos puede facilitar la permanencia del gasto urinario, aunque no modifica el pronóstico.

\section{Insuficiencia obstructiva:}

Según el nivel obstructivo es necesario crear un drenaje de orina, tan simple como un catéter o tan complejo como una nefrostomía.

\section{Terapia de reemplazo:}

La diálisis de soporte se indica en marcada sobrecarga de volumen, hipercaliemia severa (>6.5 mEq/l), signos y síntomas urémicos, acidosis metabólica severa y BUN > $00 \mathrm{mg} / \mathrm{dl}$. 


\section{Sistema Genito - Urinario y Endocrino}

Sin embargo, las condiciones clínicas pueden indicar la terapia con niveles inferiores de nitrógeno, pero con situaciones catabólicas y/o sépticas.

\section{Insuficiencia renal crónica}

La insuficiencia renal crónica (IRC) se define como la pérdida progresiva, permanente e irreversible de la tasa de filtración glomerular a lo largo de un tiempo variable, a veces incluso de años, expresada por una reducción del aclaramiento de creatinina estimado < $60 \mathrm{ml} / \mathrm{min} / \mathrm{I}, 73 \mathrm{~m} 2$.

También se puede definir como la presencia de daño renal persistente durante al menos 3 meses, secundario a la reducción lenta, progresiva e irreversible del número de nefronas con el consecuente síndrome clínico derivado de la incapacidad renal para llevar a cabo funciones depurativas, excretoras, reguladoras y endocrino metabólicas. El término insuficiencia renal crónica terminal (IRCT) se ha utilizado, fundamentalmente, para referirse a aquella situación subsidiaria de inicio de tratamiento sustitutivo de la función renal, bien mediante diálisis o trasplante, con unas tasas de incidencia y prevalencia crecientes en las dos últimas décadas.

\section{Etiología de la IRC}

Es conveniente distinguir entre aquellos procesos capaces de causar lesión renal con posterior evolución a IRC y los procesos que actúan independientemente de la enfermedad inicial y contribuyen a la progresión de la enfermedad. A la hora de analizar la etiología de la IRC en el anciano, respecto a otros grupos de edad, se evidencian diferencias importantes entre ambos.

\section{Manifestaciones clínicas y signos de IRC}

En general, las manifestaciones clínicas de la IRC aparecen de forma progresiva, manteniendo una gran variabilidad de un paciente a otro, en función de la velocidad de progresión y de la cantidad de masa renal funcionante.

Aclaramientos de creatinina inferiores a $30 \mathrm{ml} / \mathrm{min}$ marcan habitualmente la frontera en la que la IRC se hace sintomática, desarrollándose a partir de entonces un amplio espectro de manifestaciones clínicas paralelas al estadio evolutivo. Puntualizar que la clínica de la 


\section{Sistema Genito - Urinario y Endocrino}

IRC en el anciano carece de rasgos propios y que en muchas ocasiones el hallazgo casual de cifras elevadas de urea y creatinina nos apuntan al diagnóstico.

diferenciación

\begin{tabular}{|c|c|c|}
\hline Función renal & Aclaramiento de creatinina & \\
\hline$<$ Reserva funcional renal & $120-60$ & $\begin{array}{l}\text { Disminución de nefronas funcionantes y aumento del } \\
\text { filtrado en nefronas residuales. Balance equilibrado de } \\
\text { sodio, agua y ácido. }\end{array}$ \\
\hline Deterioro renal & $59-30$ & $\begin{array}{l}\text { Disminución del filtrado glomerular. Aumento de PTH. } \\
\text { Disminución de 1,25 (OH) D3. Anemia leve. }\end{array}$ \\
\hline Insuficiencia renal & $20-10$ & $\begin{array}{l}\text { Aumento del P. hiperparatiroidismo. Osteodistrofia. } \\
\text { Acidosis. Uremia. Anemia. Hipocalcemia (no siempre). } \\
\text { Astenia. Hiponatremia. Falta de concentración y } \\
\text { dilución de la orina. }\end{array}$ \\
\hline Uremia & $<10$ & $\begin{array}{l}\text { Irritabilidad. Letargia. Anemia severa. Coagulopatía. } \\
\text { Inmunosupresión. HTA. Anorexia. Vómitos. Neuropatía } \\
\text { periférica. Osteodistrofia: fracturas. Impotencia. } \\
\text { Esterilidad. Homeostasis del } \mathrm{K}_{\text {y } \mathrm{H}_{2} \mathrm{O} \text { dependiente de }} \\
\text { diuresis. Gastritis. Disnea y edema agudo de pulmón. }\end{array}$ \\
\hline
\end{tabular}

\section{Diagnóstico y evaluación de la IRC}

Ante toda sospecha de deterioro de la función renal, es indispensable la realización de una correcta investigación que nos ayude a diferenciarla de la IRA. La base diagnóstica se fundamenta en una exhaustiva historia clínica donde se recojan antecedentes personales y familiares, síntomas clínicos, parámetros analíticos y pruebas de imagen.

I. Antecedentes personales y familiares: factores de riesgo cardiovascular, uso de drogas, exposición a elementos tóxicos, así como malformaciones o enfermedades hereditarias.

2. Síntomas clínicos: previamente descritos. Destacar que en numerosas ocasiones la ausencia de síntomas o clínica inespecífica puede estar presentes, sin olvidar que la clínica urémica se manifiesta en fases muy avanzadas.

3. Parámetros analíticos: es frecuente observar las siguientes alteraciones:

\section{Hematología y metabolismo:}

a) Anemia: normocítica, normocrómica (déficit de eritropoyetina). En ocasiones, patrón microcítico (relación con sangrado o intoxicación por aluminio) o macrocítico (relacionado con déficit de ácido fólico o vit. BI2) 


\section{Sistema Genito - Urinario y Endocrino}

b) Tiempo de hemorragia: alargado (toxinas urémicas)

c) Productos del metabolismo proteico: aumentan con la disminución de la función renal

d) Creatinina: niveles en relación directa con masa muscular. Es preciso una reducción del $20-30 \%$ del FG para que se incremente su valor

e) Urea: influenciable por múltiples factores, como el aporte de proteínas en la dieta, la deshidratación, fármacos-diuréticos y corticoides, no siendo considerada como cifra única, parámetro idóneo que traduzca el FG

f) Ácido úrico: puede reflejar exclusivamente una alteración del metabolismo de las purinas. Es importante conocer que la elevación de la creatinina en sangre y la disminución de su aclaramiento estimado, son predictores tanto de muerte como de futuros eventos cardiovasculares.

\section{lones:}

a) Sodio y potasio: cifras normales hasta fases avanzadas. Hipo e hipernatremia en situaciones de sobrecarga y depleción de volumen. Hiperpotasemia en fases avanzadas (salvo en nefropatía diabética y nefropatía intersticial crónica.

b) Calcio: normal o bajo en relación al hiperparatiroidismo secundario

c) Fósforo: hiperfosforemia con IRC moderada-severa. Depósito de fosfato cálcico favorecido por hiperPTH

d) Magnesio: hipermagnesemia ligera

e) Acidosis metabólica: mal manejo de bicarbonato e incapacidad renal para excretar aniones orgánicos

f) Técnicas de imagen: importantes a la hora de aportar información complementaria. Ecografía: considerada como la prueba de elección, permite visualizar ecogenicidad, tamaño, asimetrías, posición, estado del sistema y cortico-medular.

\section{Consideraciones terapéuticas}




\section{Sistema Genito - Urinario y Endocrino}

Teniendo en cuenta el progresivo incremento en el número de ancianos afectos de IRC, tanto la monitorización cuidadosa como el tratamiento predialítico adecuado, adquieren cada vez mayor importancia. Una valoración temprana por el nefrólogo ha demostrado un aumento en la supervivencia en esta población; esto y los beneficios del tratamiento con diálisis en el anciano, son cuestiones fuera de discusión en la actualidad.

El tratamiento de los pacientes con IRC contempla los siguientes aspectos:

I. Detección de factores de reagudización y causas tratables de IRC.

2. Prevenir o, en su caso, ralentizar la progresión de la IRC:

a) Modificación de la dieta: restricción proteica moderada $(0,6-0,8 \mathrm{~g} / \mathrm{kg} / \mathrm{d}$ áa) en particular en pacientes con FG $<20 \mathrm{ml} / \mathrm{min}$, con estrecha monitorización de parámetros nutricionales, especialmente. en ancianos (asociación de dietas específicas, completas, hipoproteicas e hipercalóricas enriquecidas). La dieta debe contener unas calorías aproximadas de 35-40 Kcal/kg/día; de ellas, el 50$60 \%$ deben ser aportadas como hidratos de carbono y el resto con lípidos.

b) Control de la hipertensión arterial: medida más eficaz para enlentecer la progresión hacia la IRC. El objetivo se centra en mantener una TA diastólica aproximada a $80 \mathrm{mmHg}$. Se recomienda la reducción de la sal en la dieta, la eliminación del consumo de alcohol y el control del sobrepeso. Los IECAs y probablemente los ARA II son considerados, desde el punto de vista farmacológico, como de elección, obteniendo mayores beneficios a mayor precocidad de uso. No olvidar que en ancianos con IRC avanzada o diabetes mellitus pueden provocar deterioro de la función renal e hiperpotasemia. Los diuréticos se administrarán en situaciones de hiperhidratación, debiendo ser de asa con FG $<30 \mathrm{ml} / \mathrm{min}$. Contraindicados los ahorradores de potasio.

c) Control de la hiperlipemia: su control podría tener un efecto beneficioso en su evolución. En numerosas ocasiones las medidas dietéticas resultan insuficientes (basadas en la reducción de hidratos de carbono y aumento de grasas 


\section{Sistema Genito - Urinario y Endocrino}

poliinsaturadas), requiriendo la utilización de inhibidores de la HMG-CoA reductasa en hipercolesterolémicos y fibratos en hipertrigliceridé- micos.

d) Control de metabolismo calcio-fósforo: se recomienda la restricción de la ingesta de $\mathrm{P}$, disminuyendo el contenido proteico de la dieta. En caso de ineficacia, se recomiendan suplementos de $\mathrm{Ca}$ en forma de carbonato o acetato cálcico (2 a 6 g) cuando el FG $<40 \mathrm{ml} / \mathrm{min}$. y metabolitos de la vit. D incluido el calcitriol 0,25-I,25 mcg/día, en caso de que persista la hipocalcemia o el hiperPTH secundario.

e) Control de la hiperglucemia: se recomienda un control intensivo, con el fin de evitar la micro albuminuria $y$, por consiguiente, la neuropatía asociada. Contraindicados el uso de antidiabéticos orales (ADO) tipo sulfonilureas y biguanidas por el elevado riesgo de hipoglucemias severas y acidosis láctica, siendo necesario el uso de insulina para su control.

3. Tratamiento sintomático de las complicaciones: requiere la total individualización con monitorización estricta del tratamiento, siendo su establecimiento en el anciano difícil, en ocasiones, dada la complejidad en la valoración de los síntomas.

a) Trastornos cardiovasculares: en la insuficiencia cardíaca congestiva es primordial el control de la tensión arterial. La administración de diuréticos, la corrección de la anemia grave y de posibles arritmias (fibrilación auricular) ayudan en su tratamiento y prevención.

b) Trastorno del metabolismo del agua y del sodio: restricción hídrica en situaciones especiales (insuficiencia cardiaca (IC), HTA, edemas, hiponatremia...) vigilando probables cuadros de deshidratación. En IC adición de diuréticos de asa $y$, en ocasiones, tiacidas, para el control de edemas refractarios. En las fases poliúricas establecer balances exactos de líquidos (diuresis de 24 horas $+500 \mathrm{ml}$ ), de $\mathrm{Na}$ (ionograma en orina de 24 horas) y de K (potasemia). Se recomienda, a su vez, una dieta hiposódica para el control de la HTA. 


\section{Sistema Genito - Urinario y Endocrino}

c) Hiperpotasemia: restricción de alimentos ricos en potasio (frutas, verduras, frutos secos). Corrección de la acidosis añadiendo, en casos necesarios, resinas de intercambio iónico, vigilando el estreñimiento.

d) Acidosis metabólica: debe controlarse con suplementos de bicarbonato sódico (2-6 g/día) para mantener niveles de bicarbonato en plasma en torno a $22 \mathrm{mEq} / \mathrm{l}$. Se inicia tratamiento cuando el bicarbonato sérico es inferior a $18 \mathrm{mEq} / \mathrm{l}$.

4. Tratamiento sustitutivo renal: basado en la diálisis, bajo cualquiera de sus modalidades, o en el trasplante renal.

a) Diálisis: se define como un tratamiento sustitutivo, que cumple como principal función la de la depuración a nivel renal. La inclusión de un paciente en un programa de diálisis se debe individualizar en función de las condiciones clínicas, físicas, mentales y sociales del mismo. Actualmente, según comisiones de expertos, influenciado, a su vez, por los avances tecnológicos, no existe contraindicación alguna para desestimar este tipo de tratamiento.

b) Trasplante renal: constituye un tratamiento alternativo para la IRCT en adultos de edad avanzada. Los resultados en torno a la supervivencia han mejorado en los últimos años gracias a la meticulosidad en la selección del receptor, los cuidados perioperatorios y el uso de nuevos fármacos inmunosupresores, más seguros y eficaces, reduciendo, de forma considerable, los límites en torno a la edad del paciente previamente establecidos.

\section{Cálculos renales}

Los Cálculos renales o piedras en el riñón es uno de los desórdenes más comunes, con casi un $10 \%$ de la población que ha tenido, al menos, un cálculo renal en algún momento de su vida. Los hombres tienen cálculos más frecuentemente que las mujeres, como sucede con quienes tienen historia familiar de cálculos renales o aquellas personas que han padecido de cálculos anteriormente.

También en los niños se pueden desarrollar cálculos renales. Esto puede deberse a factores genéticos como: bajo peso al nacer, alimentación intravenosa y deformidades o 


\section{Sistema Genito - Urinario y Endocrino}

anatomía anormal del tracto urinario. De todas formas, los niños también están en riesgo de desarrollarlos si no beben suficientes líquidos o ingieren demasiada comida rápida, la cual contiene altos niveles de sal.

Los cálculos renales son como masas de cristal que se forman en el riñón. El desarrollo de los cálculos depende de los químicos que se encuentran en la orina. Ciertos químicos pueden acelerar el crecimiento de los cálculos, mientras que otros previenen la formación de estas piedras. La insuficiente ingesta de líquidos puede también contribuir a la formación de los cálculos. Si usted no bebe suficiente agua, la orina tendrá menos fluidos y más alta concentración de químicos que forman los cálculos.

Por ello, bebiendo más cantidad de agua usted ayuda a prevenir la combinación de esos químicos que forman los cálculos. La mayoría de cálculos está compuesta de calcio pero otros pueden estar conformados por ácido úrico, fosfato y otros químicos. Estos comienzan siendo de tamaño pequeño y van haciéndose más grandes a través del tiempo. Las piedras pueden permanecer en el riñón o pueden trasladarse a través del uréter (el tubo que transporta la orina desde los riñones hasta la vejiga). Los cálculos también pueden formarse en la vejiga o en la uretra (tubo que transporta la orina hacia el exterior del cuerpo).

\section{Tipos de cálculos renales}

\section{I) Cálculos de calcio}

Es el tipo de piedra más común. El calcio es un mineral que forma parte de nuestra dieta normal. El calcio que no se necesita para los huesos y los músculos pasa a los riñones. En la mayoría de las personas, los riñones eliminan ese calcio que sobra junto con el resto de la orina. Las personas que forman piedras de calcio retienen ese calcio en los riñones. El calcio que no se elimina se une a otros desperdicios para formar una piedra.

La nefrolitiasis por cálculos de sales de calcio representa entre el $75 \%$ y el $85 \%$ de todos los tipos, es más frecuente en varones; y los tipos de sales son las de oxalato de calcio y las de fosfato de calcio, esta última puede ser en forma de hidroxiapatita o en forma de 


\section{Sistema Genito - Urinario y Endocrino}

brushita. La edad de inicio de formación de estos cálculos está generalmente entre los 20 y los 39 años de edad.

\section{2) Cálculos de ácido úrico}

Se puede formar cuando hay demasiado ácido en la orina $(\mathrm{pH}<5,4)$, debido a un exceso de ácido úrico en la sangre.

Representan entre el $5 \%$ y el $10 \%$ de los casos de nefrolitiasis, y es más frecuente en varones. Las personas con cálculos de ácido úrico pueden tener o no gota, la frecuencia de gota en este grupo es de $50 \%$.

\section{3) Cálculos de cistina}

Son poco comunes. La cistina es una de las sustancias que forman los músculos, nervios y otras partes del cuerpo. La cistina se puede acumular en la orina hasta formar una piedra. La enfermedad que causa la formación de piedras de cistina es hereditaria.

Son muy poco comunes ( 1 \% de las nefrolitiasis) y son el producto de un transporte defectuoso de aminoácidos dibásicos (cisteina $\rightarrow$ disulfuro de cisteía o cistina y la lisina ornitina, arginina) en el intestino y en los túbulos renales.

\section{4) Cálculos de estruvita}

También conocida como triple fosfato, puede formarse después de una infección del sistema urinario o por presencia de cuerpos extraños en este sistema. Estas piedras contienen el mineral magnesio y el producto de desperdicio, amoníaco además de fosfato. Este tipo de piedras es producto de la infección del tracto urinario por bacterias productoras de ureasa como Proteus. Producen un cálculo mixto: carbonato de calcio (CaCO3) y estruvita (MgNH4PO4), el cual forma un cristal en forma de «Tapa de féretro» (prismas rectangulares). Es frecuente en mujeres.

\section{Patogenia}

La nefrolitiasis surge al romperse el delicado equilibrio que debe mantener la solubilidad y evitar la precipitación de las sales. Para que se forme un cálculo se necesita de: 


\section{Sistema Genito - Urinario y Endocrino}

\section{a. Sobresaturación}

La sobresaturación se produce cuando la concentración de litogénicos sobrepasa el límite hasta el que la orina puede mantenerlos en solución. Este límite lo determinan muchos factores como el pH y la concentración y la presencia de otros compuestos. Por ejemplo, el calcio con el oxalato y el fosfato con el citrato forman muchas sustancias solubles entre sí, por lo tanto, si disminuyen las concentraciones de citrato en la orina, se produce más sobresaturación, al igual que si disminuye la cantidad de agua en la orina, lo que facilita la formación de cristales.

$\mathrm{El} \mathrm{pH}$ también influye, porque al aumentar este, aumenta también la cantidad total de fosfato ionizado que se une al $\mathrm{Ca}+2$ y hace que se precipiten cada vez más brushita y apatita. Por el contrario, cuando el $\mathrm{pH}<5,5$ disminuye la frecuencia de cristales de fosfato, pero se eleva la de los cristales de ácido úrico.

\section{b. Cristalización}

Comienza con la formación de núcleos de cristales que pueden ser restos celulares o hasta otros cristales (núcleos heterogéneos). Estos núcleos se retienen en la pelvis renal; esto es posible a través de las excrecencias o proliferaciones sobre placas de apatita en papilas renales (Placas de Randall). Las Placas de Randall, que surgen en la membrana basal de la porción fina del asa de Henle, pasan a través del intersticio hacia la membrana basal del endotelio papilar cuando estas células endoteliales son lesionadas. Esto deja expuesta las placas, haciéndolas bases para la cristalización de oxalato de calcio.

Inhibidores de la formación de cristales:

a) Pirofosfato inorgánico: mayor acción contra cristales de fosfato de calcio que contra los de oxalato de calcio

b) Citrato: forma complejos solubles con el calcio

c) Glucoproteínas: inhiben la cristalización de oxalato de calcio

d) Fitato: inhibe la nucleación del oxalato cálcico, con una potencia 1000 veces superior al citrato; inhibe la nucleación del fosfato cálcico y el crecimiento cristalino del oxalato cálcico. 


\section{Sistema Genito - Urinario y Endocrino}

\section{Factores de riesgo}

Los factores que aumentan el riesgo de padecer cálculos renales son:

a) Antecedentes familiares o personales. Si alguien de tu familia tiene cálculos renales, tienes más probabilidad de padecer la enfermedad. Además, si alguna vez tuviste uno o más cálculos renales, corres un mayor riesgo de tener otro.

b) Deshidratación. No beber suficiente agua todos los días puede aumentar el riesgo de tener cálculos renales. Las personas que viven en climas cálidos y que transpiran mucho pueden presentar un riesgo mayor que otras personas.

c) Ciertas dietas. Llevar una dieta rica en proteínas, sodio (sal) y azúcar puede aumentar el riesgo de tener algunos tipos de cálculos renales. Esto es sobre todo cierto con una dieta rica en sodio. El exceso de sal en la dieta incrementa la cantidad de calcio que el riñón tiene que filtrar y aumenta, de manera importante, el riesgo de tener cálculos renales.

d) Ser obeso. Un índice de masa corporal alto, un perímetro de la cintura ancho y el aumento de peso se pueden asociar con un incremento del riesgo de tener cálculos renales.

e) Cirugía y enfermedades digestivas. La cirugía de bypass gástrico, la enfermedad inflamatoria intestinal o la diarrea crónica pueden provocar cambios en el proceso digestivo que afectan la absorción de calcio y de agua, lo que aumenta los niveles de sustancias que forman cálculos en la orina.

f) Otras enfermedades. Las enfermedades y los trastornos que pueden aumentar el riesgo de tener cálculos renales comprenden la acidosis tubular renal, la cistinuria, el hiperparatiroidismo, ciertos medicamentos y algunas infecciones de las vías urinarias.

\section{Tratamiento}

A todo paciente con nefrolitiasis debe indicarse consumir cantidades copiosas de agua y evitar siempre la deshidratación.

\section{Técnicas para la eliminación de cálculos:}




\section{Sistema Genito - Urinario y Endocrino}

a) Bloqueadores adrenérgicos al V.O.: Estos relajan el músculo ureteral y facilitan la eliminación del cálculo sin dolor

b) Las indicaciones para la extracción del cálculo son: obstrucción grave, dolor rebelde, hemorragia interna, infección

c) Litotricia extracorporal: Es la fragmentación en el sitio del cálculo por ondas de choque, en la cual el medio de transporte de estas ondas es el agua.

Nefrolitotomía percutánea: Es una técnica en la cual se hace una pequeña incisión en el flanco del lado afectado y se utiliza un transductor de ultrasonido o láser de holmio para desintegrar el cálculo (ureteroscopia con desintegración del cálculo por medio de láser holmio).

\section{BIBLIOGRAFÍA SUGERIDA}

I. Webster AC, Nagler EV, Morton RL, Masson P. Chronic Kidney Disease. Lancet. 20I7;389(I0075):I238-I252. doi:I0.I0I6/S0 I40-6736(I6)32064-5

2.

Chawla LS, Bellomo R, Bihorac A, et al. Acute kidney disease and renal recovery: consensus report of the Acute Disease Quality Initiative (ADQI) 16 Workgroup. Nat Rev Nephrol. 20 I7;13(4):24I-257. doi:I0.1038/nrneph.20I7.2

3. Hocker SE. Renal Disease and Neurology. Continuum (Minneap Minn). 2017;23(3, Neurology of Systemic Disease):722-743. doi: I 0.12 I 2/CON.0000000000000469

4.

Kalantar-Zadeh K, Fouque D. Nutritional Management of Chronic Kidney Disease. N Engl J Med. 2017;377(I8):I765-1776. doi:I0.I056/NEJMra I7003 I 2

5.

Kemmner S, Verbeek M, Heemann U. Renal dysfunction following bone marrow transplantation.J Nephrol. 2017;30(2):201-209. doi: 10.1007/s40620-0 I6-0345-y 
Sistema Genito - Urinario y Endocrino

\author{
Capítulo $\mathbf{X}$ \\ Sistema endocrino
}




\title{
Sistema Genito - Urinario y Endocrino
}

\author{
CAPITULO XII \\ SISTEMA ENDOCRINO
}

\begin{abstract}
ANATOMÍA

\section{Glándulas endocrinas}

El sistema endocrino es el conjunto de órganos y tejidos del organismo, que segregan un tipo de sustancias llamadas hormonas, que son liberadas al torrente sanguíneo y regulan algunas de las funciones del cuerpo. El cuerpo contiene dos tipos de glándulas: exocrinas y endocrinas. Las glándulas exocrinas (exo-, de exo = fuera) secretan sus productos dentro de conductos que llevan las secreciones a las cavidades corporales, a la luz de un órgano o a la superficie corporal. Las glándulas exocrinas incluyen las glándulas sudoríparas (sudor), las sebáceas (sebo), las mucosas y las digestivas. Las glándulas exocrinas se clasifican en apocrinas, holocrinas o merocrinas, según el producto que secretan.

Las glándulas endocrinas (endo-, de endon $=$ dentro) secretan sus productos (hormonas) hacia el líquido intersticial circundante más que hacía conductos. Desde el líquido intersticial, las hormonas difunden hacia los capilares y la sangre las lleva hacia las células diana distribuidas por todo el cuerpo. Las glándulas endocrinas se caracterizan por haber perdido su unión con el epitelio que las originó, por lo cual, están desprovistas de conductos excretores. Debido a que las hormonas se requieren en muy pequeñas cantidades, los niveles circulantes son bajos. Dado que dependen del aparato cardiovascular para distribuir sus productos, las glándulas endocrinas son de los tejidos más vasculares izados del cuerpo.

Las glándulas endocrinas incluyen la hipófisis, la tiroides, la paratiroides, las suprarrenales y la pineal. Aparte de las glándulas endocrinas especializadas para tal fin, existen otros órganos como el riñón, hígado, corazón y las gónadas, que tiene una función endocrina secundaria. Por ejemplo, el riñón secreta hormonas endocrinas como la eritropoyetina y
\end{abstract}




\section{Sistema Genito - Urinario y Endocrino}

la renina. La ciencia que estudia la estructura y función de las glándulas endocrinas y el diagnóstico y tratamiento de los trastornos del sistema endocrino es la endocrinología (endo-, de endon = dentro; crino-, de krinein = secreta, $y$-logia, de logos = estudio).

\section{EI hipotálamo y la glándula hipófisis}

Durante mucho tiempo, se consideró a la hipófisis o glándula pituitaria como la glándula endocrina "maestra" porque secreta varias hormonas que controlan otras glándulas endocrinas. Hoy sabemos que la hipófisis tiene a su vez un maestro: el hipotálamo. Las células en el hipotálamo sintetizan al menos 9 hormonas distintas, y la glándula hipófisis secreta 7. Juntas, estas 16 hormonas juegan papeles importantes en la regulación de, virtualmente, todos los aspectos del crecimiento, el desarrollo, el metabolismo y la homeostasis. El Hipotálamo posee una población neuronal muy variada y abundante.

El hipotálamo es una región anatómica del diencéfalo localizada entre el tercer ventrículo y la lámina terminal (límite interno), tálamo (límite superior) y globo pálido, cápsula interna, región subtalámica y pedúnculos cerebrales (limite posterior y lateral). Hacia abajo el hipotálamo se conecta con la glándula hipófisis a través del tallo hipofisario.

La glándula hipófisis es una estructura con forma de guisante que mide $1-1,5 \mathrm{~cm}$ de diámetro y descansa en la fosa hipofisaria de la silla turca del hueso esfenoides. Está unida al hipotálamo mediante un tallo, el infundíbulo y tiene dos lóbulos separados, tanto desde el punto de vista funcional como anatómico. Sus estructuras anatómicas, embriológicas y funcionales se separan en 2 porciones, el lóbulo anterior o adenohipófisis (también conocida como pars distalis) que abarca las $2 / 3$ partes del peso total de la glándula del adulto normal y el lóbulo posterior o neurohipófisis.

El lóbulo anterior de la hipófisis, también llamado adenohipófisis, constituye aproximadamente el $75 \%$ del peso total de la glándula y está compuesto de tejido epitelial. El lóbulo anterior está formado por 2 partes en el adulto: la par distalis es la porción más grande y la pars tuberales forma una vaina alrededor del infundíbulo. La adenohipófisis de origen embriológico no neurogénico es una evaginación de la orofaringe primitiva, de origen ectodérmico, conocida como bolsa de Rathke desarrollándose ésta dorsalmente y 


\section{Sistema Genito - Urinario y Endocrino}

encontrándose hacia abajo con una extensión del diencéfalo, el infundíbulo que forma el tallo y la hipófisis posterior. El lóbulo posterior de la hipófisis, llamado neurohipófisis, está compuesto de tejido neural y también consta de 2 partes: la pars nervosa, la porción bulbar más grande y el infundíbulo. Una tercera región de la glándula hipófisis llamada pars intermedia se atrofia durante el desarrollo humano fetal y deja de existir como lóbulo separado en los adultos. Embriológicamente, la neurohipófisis junto con el hipotálamo deriva del diencéfalo

\section{Tipos de células del lóbulo anterior de la hipófisis y sus hormonas}

Cinco tipos de células del lóbulo anterior de la hipófisis o adenohipófisis (somatotropas, tirotropas, gonadotropas, lactotropas y corticotropas) secretan 7 hormonas:

I. Las células somatotropas tienen forma ovoide, con gránulos secretores, y son acidofílicas (absorben ácidos fácilmente). Entre el 35 y $40 \%$ de la adenohipófisis (lóbulo anterior de la hipófisis) está constituido por células somatotropas, las cuales tardan varios años en desarrollarse y madurar. Las somatotropas secretan hormona de crecimiento humano $(\mathrm{hGH})$ o somatotropina (somato-, de sómatos = cuerpo y -tropa, de tropos = giro, cambio). La hormona de crecimiento humano, a su vez, estimula diversos tejidos para que secreten factores de crecimiento similares a la insulina, hormonas que estimulan el crecimiento general del cuerpo y regulan aspectos del metabolismo.

2. Son células basófilas, pequeñas $(100 \mu \mathrm{m})$ poco numerosas. No se sitúan en un área específica y se diferencian de las células gonadotropas por la utilización de anticuerpos específicos dirigidos sobre la subunidad $\beta$ de los dos grupos de hormonas (las unidades a son idénticas). Las tirotropas secretan hormona tiro estimulante $(\mathrm{TSH})$ o tirotropina (tiro- = relativo a la glándula tiroides). La TSH controla las secreciones y otras actividades de la glándula tiroides.

3. Las gonadotropas (gonado-, de gonée = simiente, generación) secretan 2 hormonas: la hormona foliculoestimulante $(\mathrm{FSH})$ y la hormona luteinizante (LH). Tanto la FSH como la LH actúan sobre las gónadas. Estimulan la secreción de 


\section{Sistema Genito - Urinario y Endocrino}

estrógenos y progesterona y la maduración de los ovocitos en los ovarios, y estimulan la producción de esperma y la secreción de testosterona en los testículos. Las células gonadotropas son basófilas en preparaciones histológicas.

4. Son células acidófilas que se agrupan a lo largo de capilares fenestrados ubicados en la pars distalis de la adenohipófisis. Morfológicamente, son células poliédricas con un núcleo ovalado central, su retículo endoplásmico rugoso y aparato de Golgi se hipertrofian durante el periodo de lactancia debido a la producción de prolactina. Las células somatótropas constituyen alrededor del 15\% de las células cromafines de la adenohipófisis. Las lactotropas (lacto-, de lactis $=$ leche) secretan prolactina (PRL), que inicia la producción de leche en las glándulas mamarias.

5. Son células basófilas grandes sin forma uniforme y fácilmente identificables mediante microscopía de luz debido a que sus gránulos secretorios miden de 400 a $550 \mathrm{~nm}$. Se encuentran en toda la porción anteromedial de la pars distalis. Vistas al microscopio, se caracterizan por un extenso aparato de Golgi, escaso retículo endoplásmico periférico y un núcleo que aparece excéntrico y con una escotadura. Presentan frecuentemente inclusiones lipídicas en el citoplasma. Las corticotropas secretan hormona adrenocorticotropa $(\mathrm{ACTH})$ o corticotropina (cortico- = corteza), que estimula a la corteza suprarrenal a secretar glucocorticoides como el cortisol.

Algunas hormonas corticotropas, remanentes de la pars intermedia, también secretan hormona melanocito estimulante (MSH).

\section{Hormona de crecimiento humano y factores de crecimiento similares a la insulina}

Las somatotropas son las células más numerosas en el lóbulo anterior de la hipófisis, y la hormona de crecimiento humano $(\mathrm{hGH})$ es la hormona adenohipofisaria más abundante. La hormona de crecimiento es un polipéptido de 191 aminoácidos de una sola cadena sintetizada, almacenada y secretada por las células somatótropas dentro de las alas 


\section{Sistema Genito - Urinario y Endocrino}

laterales de la adenohipófisis. La función principal de la hGH es promover la síntesis y secreción de hormonas proteicas pequeñas llamadas factores de crecimiento similares a la insulina (IGF) o somatomedinas.

\section{Hormona tiroestimulante (tirotrofina)}

Es una glicoproteina sintetizada por las células tirotropas de la hipófisis anterior (adenohipofisis). Está compuesta por dos subunidades y $B$, unidas en forma no covalente. La subunidad es común a otras hormonas glicoproteicas, LH, FSH y HCG. La subunidad B es diferente para cada hormona y es la que le confiere la especificidad biológica. La hormona tiro estimulante o tirotropina (TSH) estimula la síntesis y secreción de las 2 hormonas tiroideas, triyodotironina (T3) y tiroxina (T4), ambas producidas por la glándula tiroides. La hormona liberadora de tirotropina (TRH) del hipotálamo controla la secreción de TSH. La liberación de TRH, a su vez, depende de los niveles sanguíneos de T3 y T4; los niveles altos de T3 y T4 inhiben la secreción de TRH por retroalimentación negativa. No existe una hormona inhibidora de la tirotropina.

La TSH no atraviesa la placenta en concentraciones fisiológicas. En la semana 16 de gestación se advierte un incremento extraordinario del contenido de TSH en las células de la adenohipófisis, que permanece constante desde la semana $22^{\circ}$ hasta el final del embarazo.

Existe una estricta correlación entre TSH y la función tiroidea en el feto, la cual es relativamente independiente del eje hipotálamo-hipofiso-tiroideo materno.

La placenta actúa como una barrera totalmente impermeable a la TSH, parcialmente permeable a la triyodotironina (T3) y a la tetrayodotironina (T4) y permeable a los yoduros y a algunas drogas antitiroideas.

\section{Hormona folículo-estimulante}

La hormona estimulante del folículo (también llamada hormona folículo-estimulante, abreviada como FSH) es una hormona gonadotropina sintetizada y secretada por las células gonadotropas en la glándula pituitaria anterior. La FSH regula el desarrollo, el crecimiento, la maduración en la pubertad y los procesos reproductivos del cuerpo 


\section{Sistema Genito - Urinario y Endocrino}

humano. La FSH y la hormona luteinizante (LH) actúan de forma sinérgica en la reproducción.

En las mujeres, los ovarios son las dianas de la hormona foliculoestimulante (FSH). Cada mes la FSH inicia el desarrollo de varios folículos ováricos y hace que las células secretoras que rodean al ovocito en desarrollo comiencen a formar un saco. La FSH también estimula a las células foliculares a secretar estrógenos (hormonas sexuales femeninas). Estimula el crecimiento y el reclutamiento de los folículos ováricos inmaduros en el ovario, afectando específicamente a las células granulosas. Cuando los folículos maduran, uno de ellos se convierte en dominante.

En los hombres, la FSH estimula la producción de esperma en los testículos. La hormona liberadora gonadotrofina $(\mathrm{GnRH})$ del hipotálamo estimula la liberación de FSH. La producción de proteínas de unión a los andrógenos mediante las células de Sertoli de los testículos son esenciales para la espermatogénesis. Induce a las células de Sertoli para que secreten inhibina, y estimula la formación de uniones estrechas Sertoli-Sertoli (zónula occludens).

\section{Hormona luteinizante}

Es una hormona gonadotrópica de naturaleza glicoproteica que, al igual que la hormona folículo- estimulante o FSH, es producida por el lóbulo anterior de la hipófisis o glándula pituitaria. En las mujeres, la hormona luteinizante (LH) desencadena la ovulación, la liberación de un ovocito secundario (futuro óvulo) por un ovario. La LH estimula la formación de un cuerpo lúteo (estructura formada luego de la ovulación) en el ovario y la secreción de progesterona (otra hormona sexual femenina) por el cuerpo lúteo. Juntas, la FSH y la LH también estimulan la secreción de estrógenos por las células ováricas. Los estrógenos y la progesterona preparan al útero para la implantación de un óvulo fertilizado y ayudan a preparar a las glándulas mamarias para la secreción de leche.

En los hombres, la LH estimula a las células testiculares a secretar testosterona actuando sobre las células de Leydig en los testículos. La hormona liberadora de gonadotrofinas hipotalámica $(\mathrm{GnRH})$ controla tanto la secreción de LH como la de FSH. La LH estimula la 


\section{Sistema Genito - Urinario y Endocrino}

ovulación femenina y la producción de testosterona masculina.

\section{Prolactina}

Es una hormona peptídica segregada por células lactotropas de la parte anterior de la hipófisis, la adenohipófisis, que estimula la producción de leche en las glándulas mamarias y la síntesis de progesterona en el cuerpo lúteo. Tiene una masa molecular aproximada a 22500 daltons y su cadena polipeptídica consta de unos 199 residuos aminoácidos.

La prolactina (PRL), junto con otras hormonas, inicia y mantiene la secreción de leche en las glándulas mamarias. Por sí sola, la prolactina tiene un efecto débil. Sólo después de que las glándulas mamarias han sido estimuladas por los estrógenos, la progesterona, los glucocorticoides, la hormona de crecimiento humano, la tiroxina y la insulina, que ejercen efectos permisivos, la PRL provoca la secreción de leche.

Las hormonas que tienen un efecto sinérgico son: los estrógenos, la progesterona y la GH. La succión del pezón durante la lactancia favorece la síntesis de mayor cantidad de esta hormona. Se regula por retroalimentación positiva.

\section{Hormona adrenocorticotropa}

La ACTH es un polipéptido de 39 aminoácidos cuya secuencia varía según las especies. De los 39 aminoácidos, sólo 13 tienen actividad biológica conocida. Los restantes determinan la actividad inmunológica.

Las células corticotropas secretan, principalmente, hormona adrenocorticotropa o corticotropina (ACTH). La ACTH controla la producción y secreción de cortisol y otros glucocorticoides en la corteza (porción externa) de las glándulas suprarrenales. La hormona liberadora de corticotropina $(\mathrm{CRH})$ del hipotálamo estimula la secreción de ACTH en las células cortico tróficas.

La ACTH es sintetizada por células basófilas de la hipófisis anterior o adenohipófisis por estímulo del factor hipotalámico estimulante de la corticotropina $\mathrm{CRH}$ (corticotrofhin releasing factor), a partir de un precursor que es la proopiomelanocortina, que también da lugar a opiáceos endógenos como betaendorfinas y metaencefalinas, lipotropina (LPH) 


\section{Sistema Genito - Urinario y Endocrino}

y hormona estimulante de melanocitos $(\mathrm{MSH})$. Estímulos relacionados con el estrés, como glucosa sanguínea baja o traumatismos, y la interleucina-I, una sustancia producida por los macrófagos, también estimulan la liberación de ACTH. Los glucocorticoides inhiben la liberación de $\mathrm{CRH}$ y $\mathrm{ACTH}$ por retroalimentación negativa.

\section{Hormona melanocitoestimulante}

Las hormonas estimulantes de melanocitos (MSH) o melanotropinas son un tipo de hormonas peptídicas encargadas de estimular la producción de melanocitos en los vertebrados. Son producidas por la parte intermedia de la hipófisis (lóbulo medio) que está atrofiada en el humano y más desarrollada en los otros animales. Quizás provocan el celo en vertebrados primitivos y, por ello, entre otros cambios, inducen el cambio de color en la piel indicando celo a otros individuos de la misma especie y raza.

La hormona melanocito estimulante $(\mathrm{MSH})$ aumenta la pigmentación de la piel en anfibios estimulando la dispersión de los gránulos de melanina en los melanocitos. Su papel exacto en los seres humanos no se conoce, pero la presencia de receptores de MSH en el cerebro sugiere que podría influir sobre la actividad cerebral. Hay poca MSH circulante en los seres humanos. Sin embargo, la administración continua de $\mathrm{MSH}$ durante varios días produce oscurecimiento de la piel.

La hormona estimulante de melanocitos $\circ(\mathrm{MSH})$ en el hombre actúa sobre los melanocitos, asociados con el cambio de color en la piel. La hormona es segregada en el lóbulo intermedio de la glándula pituitaria o hipófisis. A través de la sangre, llegan a los melanocitos, unas células que se encuentran en la capa externa de la piel, epidermis, y que sintetizan la melanina, un pigmento o molécula que produce pigmentación en la piel.

Un déficit en producción de melanina, por diversos mecanismos llamado albinismo. Niveles excesivos de hormona liberadora de corticotropina $(\mathrm{CRH})$ pueden estimular la liberación de $\mathrm{MSH}$; la dopamina inhibe la liberación de $\mathrm{MSH}$.

\section{Oxitocina}

La oxitocina (del griego ỏ̧ús oxys "rápido" y Tókoৎ tokos "nacimiento") es una hormona producida por los núcleos supraóptico y paraventricular del hipotálamo que 


\section{Sistema Genito - Urinario y Endocrino}

es liberada a la circulación a través de la neurohipófisis. Durante y después del parto, la oxitocina afecta a 2 tejidos diana: el útero y las mamas de la madre. Durante el parto, el estrechamiento del cuello del útero estimula la liberación de oxitocina que, a su vez, estimula la contracción de las células del músculo liso en la pared del útero; luego del parto, estimula la eyección de la leche ("bajada") de las glándulas mamarias en respuesta al estímulo mecánico ejercido por la succión del lactante. También se piensa que su función está asociada con el contacto y el orgasmo.

En el cerebro parece estar relacionada con el reconocimiento y establecimiento de relaciones sociales y podría estar involucrada en la formación de relaciones de confianza y generosidad entre personas. Ejemplo de ello es que investigaciones han descubierto que la ausencia de la hormona oxitocina podría jugar un papel relevante en la aparición del autismo.

\section{Hormona antidiurética}

La hormona antidiurética (HAD o por sus siglas en inglés $A D H)$, también conocida como arginina vasopresina (AVP), o argipresina, es una hormona producida en el hipotálamo y que se almacena y libera a través de la neurohipófisis presente en la mayoría de mamíferos, incluyendo a los humanos.

Como su nombre lo indica, un antidiurético es una sustancia que disminuye la producción de orina. La ADH hace que los riñones devuelvan más agua a la sangre, disminuyendo el volumen urinario. La vasopresina es una hormona peptídica que controla la reabsorción de moléculas de agua mediante la concentración de orina y la reducción de su volumen en los túbulos renales, afectando así la permeabilidad tubular. En ausencia de ADH, la excreción de orina se incrementa más de 10 veces, de I a 2 litros normales hasta cerca de 20 litros por día. La ADH también disminuye la pérdida de agua a través del sudor y provoca contracción arteriola, lo cual incrementa la presión sanguínea. El otro nombre de esta hormona, vasopresina, refleja este efecto sobre la presión sanguínea. La cantidad de ADH secretada varía con la presión osmótica sanguínea y el volumen sanguíneo. 


\section{Sistema Genito - Urinario y Endocrino}

\section{Glándula tiroides}

Es una glándula endocrina, situada justo debajo de la nuez de Adán, junto al cartílago tiroides sobre la tráquea. Pesa entre 10 y 20 gramos en el adulto, y está formada por dos lóbulos en forma de mariposa a ambos lados de la tráquea, ambos lóbulos unidos por el cuello. La glándula tiroides tiene forma de mariposa y está localizada justo debajo de la laringe. Está compuesta por los lóbulos laterales derecho e izquierdo, uno a cada lado de la tráquea, conectados por un istmo (pasaje angosto) anterior a la tráquea. Casi el $50 \%$ de las glándulas tiroides tienen un tercer lóbulo pequeño, llamado lóbulo piramidal, que se extiende hacia arriba desde el istmo. La tiroides pesa, en condiciones normales, alrededor de 30 g. Sacos esféricos microscópicos llamados folículos tiroideos forman la mayor parte de la glándula tiroidea.

La tiroides tiene una cápsula fibrosa que la cubre totalmente y envía tabiques interiormente que le dan el aspecto lobuloso a su parénquima. Además, la aponeurosis cervical profunda se divide en dos capas cubriendo a la tiroides en sentido anterior y posterior dándole un aspecto de pseudocápsula, que es el plano de disección usado por los cirujanos.

La pared de cada folículo consiste principalmente en células llamadas células foliculares, la mayoría de las cuales se extienden hacia la luz (espacio interno) del folículo. Una membrana basal recubre cada folículo. Cuando las células foliculares están inactivas, su forma es achatada a escamosa, pero bajo la influencia de la TSH comienzan a secretar y adoptan una forma entre cuboides y cilíndrica achatada. Las células foliculares producen 2 hormonas: la tiroxina, que también se llama tetrayodotironina o T4 porque contiene 4 átomos de yodo, y la triyodotironina o T3, que contiene 3 átomos de yodo. La T3 y la T4 también se conocen como hormonas tiroideas.

Unas pocas células llamadas células parafoliculares o células $C$ yacen entre los folículos. Producen la hormona calcitonina, que ayuda a regular la homeostasis del calcio. Estas hormonas regulan el metabolismo basal y afectan el crecimiento y grado de funcionalidad de otros sistemas del organismo. El yodo es un componente esencial tanto para T3 como 


\section{Sistema Genito - Urinario y Endocrino}

para T4. Las glándulas paratiroides ubicadas en la cara posterior de la tiroides sintetizan la hormona paratohormona que juega un papel importante en la homeostasis del calcio. La tiroides es controlada por el hipotálamo y la glándula pituitaria (o hipófisis).

\section{Las glándulas paratiroides.}

Las glándulas paratiroides son glándulas endocrinas situadas en el cuello, por detrás de los lóbulos tiroides. La glándula paratiroides tiene forma de lenteja, con medidas aproximadas de $5 \times 3 \times 3 \mathrm{~mm}$ y un peso de $30 \mathrm{mg}$ cada una. Su color es variable entre tonos amarillos, rojizos o marrón y tiene consistencia blanda. Las glándulas paratiroideas inferiores se encuentran en estrecha relación con la arteria tiroidea inferior y el nervio laríngeo recurrente.

Estas producen la hormona paratiroidea o parathormona (PTH). Por lo general, hay cuatro glándulas paratiroides, dos superiores y dos inferiores, pero de forma ocasional puede haber cinco o más. Cuando existe alguna glándula adicional, ésta suele encontrarse en el mediastino, en relación con el istmo, o dentro de la glándula tiroides.

Histológicamente, están rodeadas de una cápsula y están formadas por tres tipos de células, las células principales encargadas de la producción de hormona paratiroidea (PTH), las células oxífilas y las células acuosas de las que se desconoce su función. Las glándulas paratiroides controlan el calcio en nuestros cuerpos, la cantidad de calcio en nuestros huesos y la cantidad de calcio en la sangre. El calcio es el elemento más importante en nuestro cuerpo (lo usamos para controlar varios sistemas), por lo que es regulado con mucho cuidado. Las glándulas paratiroides controlan el nivel de calcio en la sangre.

\section{Glándulas suprarrenales}

Las glándulas suprarrenales son dos, cada una de las cuales descansa en el polo superior de cada riñón en el espacio retroperitoneal, tienen forma de pirámide aplanada. En el adulto, cada glándula suprarrenal tiene $3-5 \mathrm{~cm}$ de altura. $2-3 \mathrm{~cm}$ de anchura y un poco menos de $\mathrm{lcm}$ de espesor, con un peso de 3,5-5 g. Al nacer apenas la mitad de este tamaño. Durante el desarrollo embrionario, las glándulas suprarrenales se diferencian 


\section{Sistema Genito - Urinario y Endocrino}

desde los puntos de vista estructural y funcional, en dos regiones distintivas: una grande, localizada periféricamente, la corteza suprarrenal (que conforma el $80 \%-90 \%$ de la glándula) y una pequeña, localizada centralmente, la medula suprarrenal. Una cápsula de tejido conectivo cubre la glándula. Las glándulas suprarrenales, igual que la glándula tiroides son muy vascularizadas.

La corteza suprarrenal produce hormonas esteroides que son esenciales para la vida. La pérdida completa de las hormonas adrenocorticales lleva a la muerte por deshidratación y desequilibrio electrolítico en el periodo de unos pocos días a una semana, a menos que se comience de inmediato con una terapia de reposición hormonal. La medula suprarrenal produce tres hormonas catecolaminas: noradrenalina, adrenalina y una pequeña cantidad de dopamina.

\section{Corteza suprarrenal}

La parte exterior de la glándula, llamada corteza suprarrenal, produce las hormonas cortisol y aldosterona. La parte interior de la glándula, llamada médula suprarrenal, produce las hormonas adrenalina y noradrenalina. La corteza suprarrenal se subdivide en tres zonas, cada una de las cuales secreta distintas hormonas. La zona externa, justo por debajo de la capsula de tejido conectivo, es la zona glomerulada. Sus células que están dispuestas en forma compacta unas cerca de otras y organizadas en racimos esféricos y columnas ramificadas, secretan hormonas llamadas mineral corticoides porque afectan la homeostasis mineral.

La zona medida o zona fasciculada, es la más ancha de las tres y tiene células organizadas en columnas largas y rectas. Las células de la zona fasciculada secretan principalmente, glucocorticoides y cortisol, llamados así porque afectan la homeostasis de la glucosa. Las células de la zona interna y la zona reticular están organizadas en cordones ramificados. Sintetizan cantidades pequeñas de andrógenos débiles, hormonas esteroideas que tienen efectos masculinizantes.

\section{Mineralocorticoides}

El principal y más potente es la aldosterona, que aumenta notablemente la concentración 


\section{Sistema Genito - Urinario y Endocrino}

de sodio, cloruros y bicarbonatos en los líquidos extracelulares, aumento considerable de los electrolitos totales en los líquidos extracelulares, lo que provoca un aumento de la reabsorción de agua por los túbulos renales causando sed y provocando polidipsia. La aldosterona también promueve la excreción de $\mathrm{H}$ en la orina; esta remoción de ácidos del cuerpo puede ayudar a prevenir la acidosis ( $\mathrm{pH}$ de la sangre por debajo de 7,35).

El sistema renina-angiotensina-aldosterona (RAA) controla la secreción de aldosterona y es el aumento de $\mathrm{K}$ en la sangre (o el líquido intersticial). La disminución en el nivel sanguíneo de $\mathrm{K}$ tiene el efecto contrario.

\section{Glucocorticoides}

Los glucocorticoides son hormonas de la familia de los corticosteroides que participan en la regulación del metabolismo de carbohidratos favoreciendo la gluconeogénesis y la glucogenólisis; poseen además actividad inmunosupresora. Su acción reguladora se extiende también al metabolismo intermedio de grasas y proteínas. Los glucocorticoides se producen principalmente en la corteza suprarrenal de los seres humanos y son el cortisol, la cortisona y la corticosterona. El cortisol es el glucocorticoide más importante en el ser humano.

Los glucocorticoides, que regulan el metabolismo y la resistencia al estrés, son el cortisol (hidrocortisona), la corticosterona y la cortisona. De estas tres hormonas secretadas por la zona fasciculada, el cortisol es el más abundante, y se le atribuye alrededor de $95 \%$ de la actividad glucocorticoide.

El control de la secreción de glucocorticoides se produce a través de un típico sistema de retroalimentación negativa. Los niveles sanguíneos bajos de glucocorticoides, primordialmente, cortisol estimula a las células neurosecretoras en el hipotálamo y secreta hormona liberadora de corticotropina $(\mathrm{CRH})$; la $\mathrm{CRH}$ junto con el nivel bajo de cortisol, promueven la liberación de ACTH en la adenohipófisis. La ACTH fluye en la sangre a la corteza suprarrenal donde estimula la secreción de glucocorticoides (en mucha menor medida, la ACTH también estimula la secreción de aldosterona).

Los glucocorticoides tienen los siguientes efectos: 


\section{Sistema Genito - Urinario y Endocrino}

I. Degradación de proteínas

2. Formación de Glucosa

3. Lipolisis

4. Resistencia al estrés

5. Efectos antinflamatorios

6. Depresión de las respuestas inmunitarias.

\section{Andrógenos}

Los andrógenos son hormonas sexuales masculinas y corresponden a la testosterona, la androsterona y la androstenediona. Los andrógenos son hormonas esteroideas del ciclopentanoperhidrofenantreno, cuya función principal es estimular el desarrollo de los caracteres sexuales masculinos. Luego de la pubertad en los hombres, el andrógeno testosterona también se libera en una cantidad mucho mayor en los testículos. En situaciones de estrés y durante el ejercicio, los impulsos del hipotálamo estimulan a las neuronas simpáticas preganglionares, que, a su vez, estimulan a las células cromafines a secretar adrenalina y noradrenalina. Estas dos hormonas aumentan en gran medida la respuesta de lucha o huida. Por otra parte, aumentan el gesto cardíaco y, por ende, la tensión arterial mediante el incremento de la frecuencia cardíaca y la fuerza de concentración

También aumentan la irrigación del corazón, el hígado, los músculos esqueléticos y el tejido adiposo, dilatan las vías aéreas y aumentan los niveles sanguíneos de glucosa y de ácidos grasas.

\section{Medula suprarrenal}

La región interna de la glándula suprarrenal, la medula suprarrenal, es un ganglio simpático modificado del sistema nervioso autónomo (SNA). Se desarrolla del mismo tejido embrionario que los otros ganglios simpáticos, pero sus células, que carecen de axones, forman cúmulos alrededor de los grandes vasos sanguíneos. En lugar de liberar un neurotransmisor, las células de la medula suprarrenal secretan hormonas. Las células productoras de hormonas, llamadas células cromafines, están inervadas por neuronas 


\section{Sistema Genito - Urinario y Endocrino}

simpáticas preganglionares en el SNA. Debido a que el SNA ejerce un control directo sobre las células cromafines, la liberación hormonal puede producirse de manera muy rápida.

Las dos hormonas principales sintetizadas por la medula suprarrenal son la adrenalina y la noradrenalina. Las células cromafines de la medula suprarrenal secretan una cantidad singular de estas hormonas (un $80 \%$ de adrenalina y un $20 \%$ noradrenalina) Las hormonas de la medula suprarrenal intensifican la respuesta simpática que ocurre en otras partes del cuerpo.

\section{Islotes pancreáticos}

El páncreas es tanto una glándula endocrina como una glándula exocrina. Órgano aplanado que mide cerca de $12,5-15 \mathrm{~cm}$ de largo, el páncreas se localiza en el marco duodenal, la primera parte del intestino delgado, y tiene una cabeza, un cuerpo y una cola. Casi el $99 \%$ de las células del páncreas se disponen en racimos llamados acinos.

Estructuras microscópicas irregulares, consistentes en cuerdas de células endocrinas que están dispersas por todo el páncreas, entre los acinas exocrinos. Cada islote está rodeado de fibras de tejido conjuntivo y penetrado por una red de capilares. Hay cuatro tipos principales de células. Las más abundantes son las células beta (50-80 por ciento), que segregan insulina. Las células alfa (5-20 por ciento) segregan glucagón. Las células PP (I035 por ciento) segregan polipéptido pancreático. Las células delta (aproximadamente un 5 por ciento) segregan somatostatina.

Los acinos producen enzimas digestivas, que fluyen al tubo digestivo a través de una red de conductos. Diseminados entre los acinos exocrinos hay I-2 millones de pequeños racimos de tejido endocrino llamados islotes pancreáticos o islotes de Langerhans. Abundantes capilares irrigan a las porciones exocrina y endocrina del páncreas.

\section{Tipos celulares en los islotes pancreáticos}

Cada islote pancreático incluye 4 tipos de células secretoras de hormonas:

I. Las alfa o células A constituyen cerca del 17\% de las células de los islotes pancreáticos y secretan glucagón 


\section{Sistema Genito - Urinario y Endocrino}

2. Las betas o células B constituyen cerca del $70 \%$ de las células de los islotes pancreáticos y secretan insulina

3. Las deltas o células $\mathrm{D}$ constituyen cerca del $7 \%$ de las células de los islotes pancreáticos y secretan somatostatina

4. Las células $F$ constituyen el resto de las células de los islotes pancreáticos y secretan polipéptido pancreático.

Las interacciones de las 4 hormonas pancreáticas son complejas y no están completamente dilucidadas. Si sabemos que el glucagón eleva el nivel de glucosa sanguínea y la insulina lo baja. La somatostatina actúa de manera paracrina inhibiendo la liberación de insulina y de glucagón de las células beta y alfa vecinas. También puede actuar como una hormona circulante disminuyendo la absorción de nutrientes desde el tubo digestivo. Además, la somatostatina inhibe la secreción de la hormona de crecimiento. El polipéptido pancreático inhibe la secreción de somatostatina, la contracción de la vesícula biliar y la secreción de enzimas digestivas por el páncreas

\section{Ovarios y testículos}

Las gónadas son los órganos que producen los gametos: espermatozoides en los hombres y ovocitos en las mujeres. Además de su función reproductiva, las gónadas secretan hormonas. Los ovarios, cuerpos ovalados pares localizados en la cavidad pelviana femenina, producen diversas hormonas esteroideas incluyendo 2 estrógenos (estradiol y estrona) y progesterona. Estas hormonas sexuales femeninas, junto con la FSH y la $\mathrm{LH}$ de la adenohipófisis, regulan el ciclo menstrual, mantienen el embarazo y preparan las glándulas mamarias para la lactancia.

También promueven el crecimiento de las mamas y el ensanchamiento de las caderas en la pubertad y ayudan a mantener estos caracteres sexuales secundarios. Los ovarios también producen inhibina, una hormona proteica que inhibe la secreción de la hormona foliculoestimulante (FSH). Durante el embarazo, los ovarios y la placenta producen una hormona peptídica llamada relaxina $(R L X)$, que aumenta la flexibilidad de la sínfisis del pubis durante el embarazo y ayuda a dilatar el cuello uterino durante el trabajo de parto y 


\section{Sistema Genito - Urinario y Endocrino}

el nacimiento. Estas acciones ayudan a facilitar el pasaje del bebé, agrandando el canal de parto.

Las gónadas masculinas, los testículos, son glándulas ovaladas que yacen en el escroto. La hormona principal producida y secretada por los testículos es la testosterona, un andrógeno u hormona sexual masculina. La testosterona estimula el descenso de los testículos antes del nacimiento, regula la producción de espermatozoides y estimula el desarrollo y el mantenimiento de los caracteres sexuales masculinos, como el crecimiento de la barba y la tonalidad más grave de la voz. Los testículos también producen inhibina, que inhibe la secreción de FSH. La estructura detallada de los ovarios y los testículos y los papeles específicos de las hormonas sexuales.

\section{Glándula pineal y timo}

Su forma se asemeja a un pequeño cono de pino (de ahí su nombre), y está ubicada en el epitálamo cerca del centro del cerebro, entre los dos hemisferios, metida en un surco donde las dos mitades del tálamo se unen. Es una glándula endocrina pequeña adosada al techo del tercer ventrículo del cerebro en la línea media. Forma parte del epitálamo y se localiza entre los 2 colículos superiores, tiene una masa de 0,I-0,2 g y está cubierta por una cápsula formada por la piamadre. La glándula consiste de masas de neuroglía y células secretoras llamadas pinealocitos. Produce melatonina, una hormona derivada de la serotonina que afecta a la modulación de los patrones del sueño, tanto a los ritmos circadianos como estacionales.

El timo es un sistema linfoide primario especializado del sistema inmunológico. Dentro de la glándula timo, maduran las células $T$ o linfocitos $T$. Las células $T$ son imprescindibles para el sistema inmune adaptativo, mediante el cual el cuerpo se adapta específicamente a los invasores externos.

El timo está localizado detrás del esternón entre los pulmones. Debido a su papel en la inmunidad Las hormonas producidas por el timo (timosina, factor humoral tímido, factor tímido y timopoyetina) promueven la maduración de las células $\mathrm{T}$ (un tipo de glóbulo blanco sanguíneo que destruye microbios y otras sustancias extrañas) y pueden retardar el 


\section{Sistema Genito - Urinario y Endocrino}

proceso de envejecimiento.

A pesar de su pequeño tamaño (aproximadamente: $5-6 \mathrm{~cm}$ de longitud, 4-5 cm de ancho, 6-8 mm de espesor y 30-40 g de peso), esta glándula cumple una función primordial en el sistema inmunitario, tanto que su ausencia por accidente o defecto genético provoca una inmunodeficiencia severa y una alta propensión a las infecciones.

Concretamente, la función del timo es la de madurar y diferenciar los linfocitos T provenientes de la médula ósea (estas células son un tipo de leucocito o glóbulo blanco, cuyo cometido general es reconocer y destruir sustancias extrañas o agentes infecciosos).

\section{Fisiología del sistema endocrino}

Los sistemas nervioso y endocrino actúan juntos para coordinar las funciones de todos los aparatos y sistemas del cuerpo. Cabe recordar que el sistema nervioso actúa a través de impulsos nerviosos (potenciales de acción) conducidos por los axones de las neuronas. El sistema endocrino también controla las funciones corporales liberando mediadores llamados hormonas, pero los medios de control de los dos sistemas son muy diferentes.

\section{El hipotálamo y la glándula hipófisis}

La función principal del hipotálamo es mantener la homeostasis o equilibrio de todo el cuerpo. Esta estructura desempeña de intermediario entre el sistema nervioso y el sistema endocrino. Su función endocrina fundamental es el control de la glándula pituitaria produciendo sustancias químicas que estimulan o suprimen las secreciones hormonales de la hipófisis. (jimenez, 2015)

Este sistema se conoce como el eje hipotálamo-hipofisario. Cuando el hipotálamo recibe ciertas señales del sistema nervioso, libera unas sustancias denominadas neurohormonas.

Éstas estimulan o inhiben la secreción de hormonas de la glándula pituitaria, que controlarán, a su vez, la liberación de hormonas de otras glándulas del cuerpo.

El hipotálamo posee neuronas que liberan y captan noradrenalina, serotonina y dopamina, permitiendo la regulación de los niveles hormonales. Las hormonas del hipotálamo más destacadas son:

a) Hormona liberadora de corticotropina. Como su nombre indica, promueve 


\section{Sistema Genito - Urinario y Endocrino}

la liberación de corticotropina. De esta forma, envía señales a la glándula pituitaria para que estimule a las glándulas suprarrenales. Éstas últimas liberan corticosteroides (cortisol), una sustancia importante para el metabolismo y el sistema inmunológico.

b) Hormona antidiurética, también llamada arginina vasopresina. Controla la cantidad de fluidos, glucosa y sales en la sangre. Además de producir una mayor concentración en la orina, así como una disminución de su cantidad.

c) Hormona liberadora de gonadotropina. Es esencial para la reproducción sexual. Esta hormona estimula a la hipófisis (pituitaria) para liberar dos hormonas esenciales para un correcto funcionamiento de los ovarios o testículos. Éstas son la hormona folículo estimulante (FSH) y la hormona luteinizante (LH).

d) Hormona liberadora de la hormona del crecimiento (somatocrinina). Segrega hormona del crecimiento, que sirve para mantener un tamaño y composición corporal adecuados en los niños. En los adultos, es útil para mantener los huesos sanos y una masa muscular propicia. También parece influir en la distribución de la grasa.

\section{La Hipófisis}

La hipófisis es la glándula "reina" de nuestro organismo debido a que en ella se producen o segregan múltiples hormonas, algunas de ellas son hormonas reguladoras que dirigen el funcionamiento de gran parte del sistema endocrino. Esta glándula consta de dos partes bien diferenciadas: hipófisis anterior o adenohipófisis e hipófisis posterior o neurohipófisis. Ambas glándulas intervienen en el control de la secreción hormonal de múltiples glándulas periféricas, a saber: tiroides, suprarrenales, y gónadas masculinas (testículos) y femeninas (ovarios). (Neonatales, 2016). En la hipófisis anterior o adenohipófisis se producen y segregan 6 hormonas diferentes:

a) Gh u hormona de crecimiento: fundamental para el crecimiento lineal durante la infancia y la adolescencia y también necesaria para el mantenimiento de la salud y el bienestar durante la edad adulta. 


\section{Sistema Genito - Urinario y Endocrino}

b) TSH u hormona estimulante del tiroides: esencial para la regulación de la glándula tiroides.

c) LH y FSH u hormonas reguladoras de las gónadas: responsables del correcto funcionamiento de los ovarios en las mujeres y los testículos en los varones.

d) ACTH u hormona reguladora de la corteza suprarrenal: esencial en el mantenimiento del equilibrio metabólico.

e) Prolactina: necesaria para la lactancia e influye también en la función sexual.

f) En la hipófisis posterior o neurohipófisis se liberan hormonas que previamente se han segregado en el hipotálamo y han sido transportadas hasta aquí a través del tallo hipofisario. Son fundamentalmente vasopresina y oxitocina.

g) La Vasopresina u hormona antidiurética: regula la cantidad de orina que eliminan nuestros riñones permitiendo que éstos ahorren agua y no tengamos que estar orinando continuamente.

h) La Oxitocina aumenta la fuerza de las contracciones del útero durante la fase final del parto y también facilita la lactancia.

\section{Glándulas tiroides}

La tiroides, que se encuentra en la parte frontal del cuello inferior, tiene forma de corbata o mariposa y produce las hormonas tiroideas tiroxina y triyodotironina (pronunciada: tryojo-oh-doe-THY-ruh-neen). Estas hormonas controlan la velocidad a la que las células queman combustibles de los alimentos para producir energía.

La producción y liberación de hormonas tiroideas está controlada por la tirotropina (pronuncia: thy-ruh-TRO-pin), que es secretada por la glándula pituitaria. Cuanta más hormona tiroidea hay en el torrente sanguíneo de una persona, las reacciones químicas se producen más rápidamente en el cuerpo. El 50\% de las glándulas tiroides tienen un tercer lóbulo pequeño, llamado lóbulo piramidal, que se extiende hacia arriba desde el istmo. La tiroides pesa alrededor de $30 \mathrm{~g}$ en lo normal.

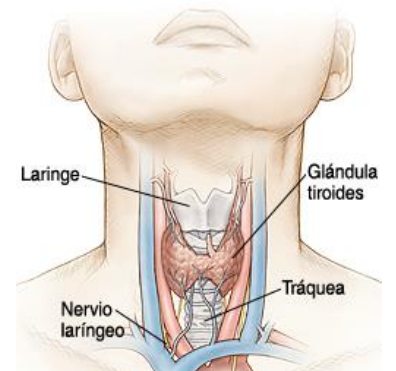
Los sacos esféricos llamados folículos tiroideos forman parte de la 


\section{Sistema Genito - Urinario y Endocrino}

glándula tiroidea. La pared de cada folículo consiste principalmente en células llamadas células foliculares, los cuales se extienden hacia la luz (espacio interno) del folículo, cuando las células foliculares están inactivas, su forma es achatada a escamosa, pero bajo la influencia del TSH comienzan a secretar y adoptan una forma entre cuboides y cilíndrica achatada.

Las células foliculares producen 2 hormonas:

- Tiroxina que también se llama Tetrayodotironina o T4 (4 átomos de yodo), y la Triyodotironina o T3 (3 átomos de yodo). Aunque la T4 y T3 también se conoce como hormonas tiroideas.

Células parafoliculares o células $C$ yacen entre los folículos. Producen la hormona Calcitonina, que ayuda a regular la homeostasis de calcio.

\section{Formación, Almacenamiento y Liberación de hormonas tiroideas}

La tiroides es la única glándula endocrina que almacena su producto secretorio en grandes cantidades, normalmente, un abastecimiento para unos 100 días. La síntesis y secreción de T3 y T4 ocurre de la siguiente manera.

I. Atrapamiento de yoduro. Las células foliculares tiroideas atrapan iones yoduro (I) por transporte activo desde la sangre hacia el citosol.

2. Síntesis de tiroglobulina. Mientras las células foliculares están atrapando I, la tiroglogulina (TGB) se están sintetizando.

3. Oxidación del yoduro. Algunos aminoácidos en la TGB son tirosinas que van a ser yodadas. Sin embargo, los iones de yoduro cargados negativamente no pueden unirse a la tirosina hasta que sufran una oxidación (perdida de electrones) a yodo molecular.

4. Yodación de Tirosina. Se forman las moléculas de yodo (12) y reaccionan con las tirosinas que son parte de la molécula de tiroglobulina. La unión de un átomo de yodo produce monoyodotirosina (TI) y la segunda produce diyodotirosina T2.

5. Unión de $\mathbf{T I}$ y T2. Durante el último paso en la síntesis de la hormona tiroidea, 2 moléculas de T2 se unen para formar T4 o T1, y T2 se unen para formar T3.

6. Pinocitosis y digestión del coloide. Gotitas de coloide vuelven a entrar en los 


\section{Sistema Genito - Urinario y Endocrino}

celulares foliculares por pinocitosis y se unen a los lisosomas.

7. Secreción de hormonas tiroideas. Como la T3 y la T4 son liposolubles, difunden a través de la membrana plasmática hacia el líquido intersticial y luego hacia la sangre.

8. Transporte en la sangre. El $99 \%$ de la T3 y la T4 se combina con proteínas de transporte en la sangre, principalmente, con la globulina de unión a la tiroxina.

\section{Acciones de las hormonas tiroideas}

La mayoría de las células del cuerpo tienen receptores para hormonas tiroideas, la T3 y la T4 ejercen sus efectos en todo el organismo.

a) Las hormonas tiroideas aumentan el índice metabólico basal (IMB) o metabolismo basal, o la tasa de consumo de oxígeno en condiciones estándar o basales (despierto, en reposo y en ayunas), estimulando el uso de oxigeno celular para producir ATP

b) Un segundo efecto importante de las hormonas tiroideas es estimular la síntesis de bombas de sodio-potasio adicionales (ATPasa $\mathrm{Na}+/ \mathrm{K}+$ ), las cuales emplean grandes cantidades de ATP para transportar continuamente iones de sodio $(\mathrm{Na}+)$ desde el citosol hacia el líquido extracelular e iones de potasio $(\mathrm{K}+)$ y desde el líquido extracelular hacia el citosol

c) En la regulación del metabolismo, las hormonas tiroideas estimulan la síntesis de proteínas y aumentan el empleo de glucosa y ácidos grasos para la producción de ATP

d) Juntos con la hormona de crecimiento humano y la insulina, las hormonas tiroideas aceleran el crecimiento corporal, en particular, el crecimiento del sistema nervioso y el sistema esquelético.

\section{Control de la secreción de hormonas tiroideas}

La hormona liberadora de tirotrofina $(\mathrm{TRH})$ del hipotálamo y la hormona tiroestimulante (TSH) de la adenohipófisis estimulan la síntesis y liberación de hormonas tiroideas.

I) Niveles sanguíneos bajos de T3 y T4 o el índice metabólico bajo estimulan al hipotálamo a secretar TRH

2) La TRH entran en las venas portales hipofisarias y fluye hacia la adenohipófisis, donde estimula a las células tirotróficas a secretar TSH 


\section{Sistema Genito - Urinario y Endocrino}

3) La TSH estimula virtualmente todos los aspectos de la actividad de la célula folicular tiroidea, incluyendo la captación de yoduro

4) Los celulares foliculares tiroideas liberan T3 y T4 hacia la sangre hasta que el índice metabólico regresa a normalidad

5) El nivel elevado de T3 inhibe la liberación de TRH y de TSH (inhibición por retroalimentación negativa).

\section{Glándulas paratiroides}

Incluidas y rodeadas parcialmente por la cara posterior de los lóbulos laterales de la glándula tiroides, hay varias masas pequeñas y redondeadas llamadas glándulas paratiroides. Cada una tiene una masa de alrededor de $40 \mathrm{mg}(0,04 \mathrm{~g})$. En general, hay una glándula paratiroides superior y una inferior adosadas a cada lóbulo tiroideo lateral, para un total de 4.

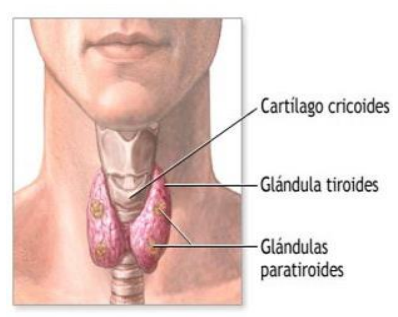

Desde el punto de vista microscópico, las glándulas paratiroides contienen 2 clases de células epiteliales. Las células más numerosas, llamadas las células principales, producen hormona paratiroidea (PTH), también llamada parathormona. Se desconoce la función del otro tipo de células, llamadas células oxífilas. No obstante, su presencia claramente ayuda a identificar la glándula paratiroides en el análisis histopatológico debido a sus características típicas de tinción. Además, en un cáncer de las glándulas paratiroides, las células oxífilas secretan PTH.

\section{Hormona paratiroidea}

La hormona paratiroidea es el regulador principal de los niveles de calcio $(\mathrm{Ca} 2+)$, 


\section{Sistema Genito - Urinario y Endocrino}

magnesio (Mg2+) e iones fosfato (HPO42-) en la sangre. La acción específica de la PTH es incrementar el número y la actividad de los osteoclastos. El resultado es un aumento de la resorción ósea, que libera calcio iónico $(\mathrm{Ca2+)}$ y fosfatos (HPO42-) hacia la sangre. La PTH también actúa sobre los riñones. Primero, disminuye la velocidad de pérdida del $\mathrm{Ca} 2+y$ el Mg2+de la sangre hacia la orina. Segundo, aumenta la pérdida de HPO42-desde la sangre hacia la orina. Debido a que se pierde más HPO42-en la orina que el que se gana desde los huesos, la PTH disminuye el nivel sanguíneo deHPO42-y aumenta los niveles sanguíneos de $\mathrm{Ca} 2+y \mathrm{Mg} 2+$. Un tercer efecto de la PTH en los riñones, es el de promover la producción de la hormona calcitriol, forma activa de la vitamina $\mathrm{D}$. El calcitriol, también conocido comol, 25-dihidroxivitamina D3, incrementa la velocidad de absorción de Ca2+, HPO42-y Mg2+desde el tubo digestivo hacia la sangre. El nivel de calcio sanguíneo controla en forma directa la secreción de calcitonina y hormona paratiroidea por una vía de retroalimentación negativa que no involucra la hipófisis.

\section{Glándulas suprarrenales}

La corteza suprarrenal produce hormonas esteroides que son esenciales para la vida. La pérdida completa de las hormonas adrenocorticales lleva a la muerte por deshidratación y desequilibrio electrolítico en el periodo de unos pocos días a una semana, a menos que se comience de inmediato con una terapia de reposición hormonal. La médula suprarrenal produce tres hormonas catecolaminas: noradrenalina, adrenalina y una pequeña cantidad de dopamina.

Las glándulas suprarrenales son órganos extraperitoneales ubicados en el polo superior de los riñones. Están conformadas por la corteza suprarrenal que constituye $90 \%$ de la glándula y que envuelve otra zona, la médula. Ambas están contenidas en una cápsula fibrosa. Estas glándulas están muy irrigadas y además presentan una circulación de tipo sinusoidal ubicada en la corteza que lleva las hormonas esteroides allí sintetizadas a la médula suprarrenal (MS); este hecho tiene una importante implicación en la comunicación funcional entre ambas zonas como se verá más adelante. Ambas zonas son drenadas por una vena única. Por otra parte, la glándula suprarrenal recibe inervación proveniente del 


\section{Sistema Genito - Urinario y Endocrino}

sistema nervioso autónomo que regula la secreción de catecolaminas por la MS, las que modulan, a su vez, la secreción de esteroides suprarrenales.

La glándula suprarrenal al igual que la hipófisis tiene un doble origen embriológico. La corteza deriva del mesodermo y la médula del ectodermo; sin embargo, ambas zonas están relacionadas funcionalmente. Esta glándula es imprescindible para la vida y las alteraciones en el funcionamiento de ambas zonas, dan lugar a graves patologías.

Durante el desarrollo fetal la corteza suprarrenal representa $0.5 \%$ del peso corporal. Está formada por tres zonas, la subcapsular o definitiva, una zona transicional y la llamada corteza fetal que es la de mayor tamaño y que involuciona después del nacimiento. La corteza suprarrenal fetal sintetiza el andrógeno dehidroepiandrosterona (DHEA), que es el precursor que utiliza la placenta para la síntesis de estrógenos en el embarazo. La placenta humana no cuenta con las enzimas que transforman progesterona a andrógenos y, por tanto, no puede sintetizar por sí misma los estrógenos.

En la corteza suprarrenal del adulto pueden diferenciarse tres zonas histológica y fisiológicamente diferentes: glomerulosa, fascicular y reticular, que se diferencian durante el crecimiento del niño. La presencia de enzimas esteroidogénicas que participan en las etapas finales de la síntesis de glucocorticoides (GC), mineralocorticoides (MC) y andrógenos suprarrenales es diferente en las tres zonas y este hecho les confiere sus particulares características fisiológicas. (Marta C. Romano, 20I6)

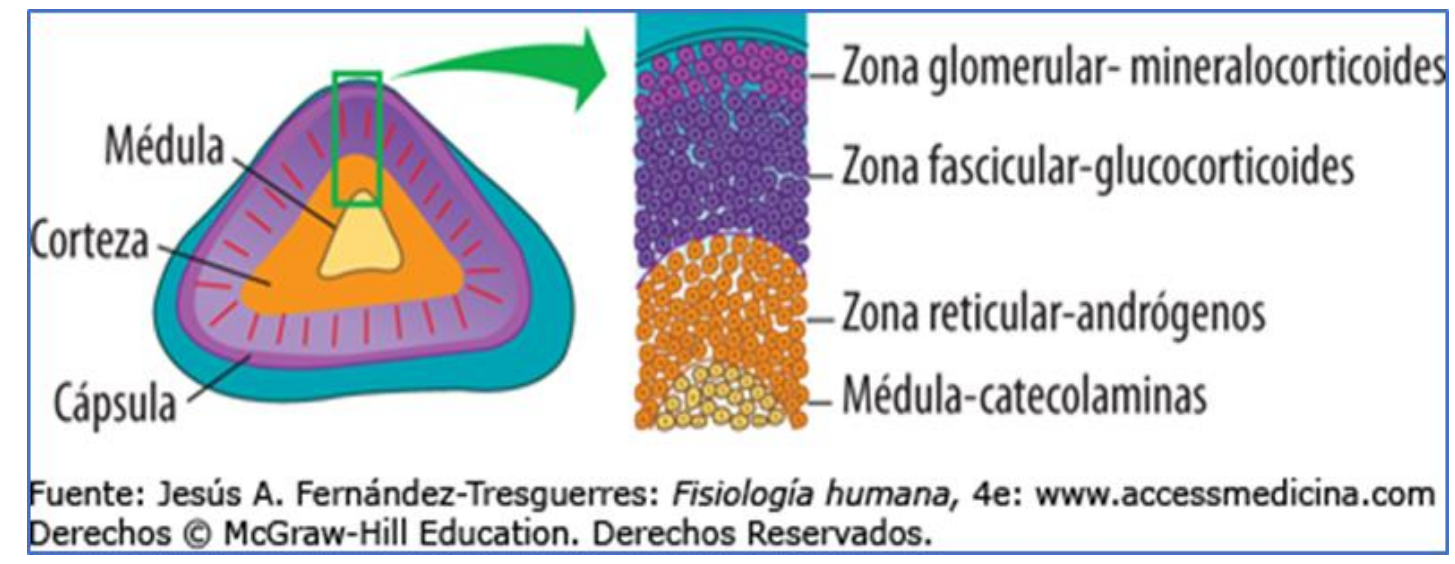




\section{Sistema Genito - Urinario y Endocrino}

\section{Islotes pancreáticos}

El páncreas, es un órgano aplanado que mide cerca de $12,5-15 \mathrm{~cm}$ de largo, el páncreas se localiza en el marco duodenal, la primera parte del intestino delgado, y tiene una cabeza, un cuerpo y una cola. Casi el $99 \%$ de las células del páncreas se disponen en racimos llamados ácinos.

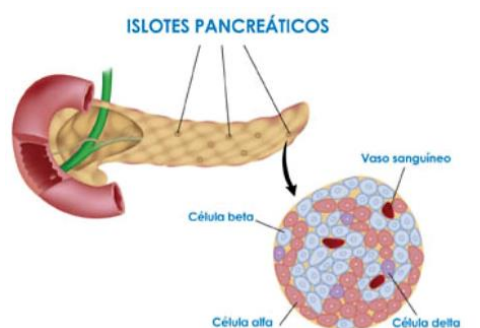

Los ácinos producen enzimas digestivas, que fluyen al tubo digestivo a través de una red de conductos. Diseminados entre los ácinos exocrinos hay I-2 millones de pequeños racimos de tejido endocrino llamados islotes

pancreáticos o islotes de Langerhans.

Tipos celulares en los islotes pancreáticos

Cada islote pancreático incluye 4 tipos de células secretoras de hormonas:

I. Las alfa o células A: constituyen cerca del $17 \%$ de las células de los islotes pancreáticos y secretan glucagón.

2. Las beta o células B: constituyen cerca del $70 \%$ de las células de los islotes pancreáticos y secretan insulina.

3. Las delta o células $\mathrm{D}$ : constituyen cerca del $7 \%$ de las células de los islotes pancreáticos y secretan somatostatina.

4. Las células F: constituyen el resto de las células de los islotes pancreáticos y secretan polipéptido pancreático.

Las interacciones de las 4 hormonas pancreáticas son complejas y no están completamente dilucidadas. Si sabemos que el glucagón eleva el nivel de glucosa sanguínea y la insulina lo baja, la somatostatina actúa de manera paracrina inhibiendo la liberación de insulina y de glucagón de las células beta y alfa vecinas. También puede actuar como una hormona circulante disminuyendo la absorción de nutrientes desde el tubo digestivo. Además, la somatostatina inhibe la secreción de la hormona de crecimiento. El polipéptido pancreático inhibe la secreción de somatostatina, la 


\section{Sistema Genito - Urinario y Endocrino}

contracción de la vesícula biliar y la secreción de enzimas digestivas por el páncreas.

\section{Regulación de la secreción de glucagón e insulina}

La acción principal del glucagón es la de elevar el nivel de glucosa sanguínea cuando cae por debajo de lo normal. La insulina, por otro lado, ayuda a disminuir el nivel de glucosa cuando está muy alto. El nivel de glucosa sanguínea controla la secreción de glucagón e insulina por retroalimentación negativa. El nivel bajo de glucosa sanguínea (hipoglucemia) estimula la secreción de glucagón en las células alfa de los islotes pancreáticos. El glucagón actúa en los hepatocitos acelerando la conversión de glucógeno en glucosa (glucogenolisis) y promoviendo la formación de glucosa a partir del ácido láctico y ciertos aminoácidos (gluconeogenesis).

Como resultado, los hepatocitos liberan glucosa hacia la sangre más rápidamente, y el nivel sanguíneo de glucosa se eleva. Si la glucosa sanguínea sigue subiendo, el nivel de glucosa sanguínea alto (hiperglucemia) inhibe la liberación de glucagón (retroalimentación negativa). La glucosa sanguínea alta (hiperglucemia) estimula la secreción de insulina en las células beta de los islotes pancreáticos.

La insulina actúa en varias células del cuerpo acelerando la difusión facilitada de glucosa hacia las células, especialmente, las fibras de músculo esquelético, acelerando la conversión de glucosa en glucógeno (glucogenogenesis), aumentando la captación de aminoácidos por las células y la síntesis de proteínas, acelerando la síntesis de ácidos grasos (lipogenesis), disminuyendo la conversión de glucógeno en glucosa (glucogenolisis) y disminuyendo la formación de glucosa a partir de ácido láctico y aminoácidos (gluconeogenesis).

\section{Glándula pineal y timo}

La glándula pineal (en forma de piña) es una glándula endocrina pequeña adosada al techo del tercer ventrículo del cerebro en la línea media. Forma parte del epitálamo y se localiza entre los 2 colículos superiores, tiene una masa de 0,I-0,2 g y está cubierta por una cápsula formada por la piamadre. La glándula consiste de masas de neuroglia y células secretoras llamadas pinealocitos

El timo está localizado detrás del esternón entre los pulmones. Debido a su papel en la 


\section{Sistema Genito - Urinario y Endocrino}

inmunidad, las hormonas producidas por el timo (timosina, factor humoral tímido, factor tímido y timopoyetina) promueven la maduración de las células $\mathrm{T}$ (un tipo de glóbulo blanco sanguíneo que destruye microbios y otras sustancias extrañas) y pueden retardar el proceso de envejecimiento.

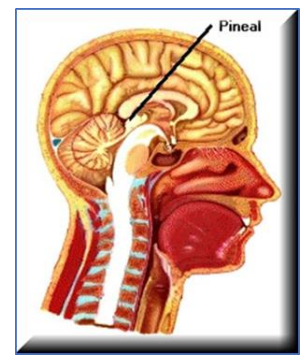

La glándula pineal es una pequeña glándula endocrina adosada al techo del tercer ventrículo cerebral, en la línea media. Pese a que muchas características anatómicas de dicha glándula se han conocido de tiempo atrás todavía no se dilucida su función fisiológica. Se sabe que secreta la metonina hormona de tipo amina derivadas de la serotodina; se libera en mayores cantidades cuando hay oscuridad y en cantidades menores bajo la luz solar bajo esta secuencia:

I. La luz entra en los ojos, llega a la retina y estimula a los fotorreceptores

2. Las hormonas retinianas activadas por los fotorreceptores transmiten impulsos al núcleo supraquiasmático del hipotálamo

3. Desde el núcleo mencionado, viajan impulsos nerviosos al ganglio cervical superior.

4. Fibras postganglionares del ganglio cervical superior se proyectan a la glándula pineal y forman sinapsis con las células de dicha glándula

5. En la oscuridad, las neuronas retinianas transmiten menos impulsos a la glándula pineal por intermediación del núcleo y ganglio citado

6. La ausencia de noradrenalina estimula la secreción de melatonina de la célula de la glándula pineal y el resultado es la somnolencia

7. Bajo condiciones de luz brillante, la noradrenalina que secreta fibras simpáticas, inhibe la liberación de la melatonina en la glándula pineal

8. La inhibición de la secreción de la melatonina tiene como efecto falta de somnolencia. Así pues, es la liberación de esta hormona depende del ciclo circadiano de luz-oscuridad.

Entre otras funciones que puede presentar dicha glándula se dice que favorece la regeneración celular, la regulación del sueño, la disminución del estrés y la cura de 


\section{Sistema Genito - Urinario y Endocrino}

enfermedades como el cáncer, cardiopatías, SIDA y Alzheimer. Por otro lado, se dice que la melatonina está estrechamente relacionada con el desánimo característico del invierno por la alta secreción de la melatonina, ya que ésta se elabora en base a la serotonina $y$, al disminuir sus niveles cerebrales, se afectaría el estado de ánimo. Incluso se afirma que bastarían dos semanas de insuficiencia de luz en individuos predispuestos, para reducir los niveles de serotonina, produciéndose una depresión.

\section{El timo}

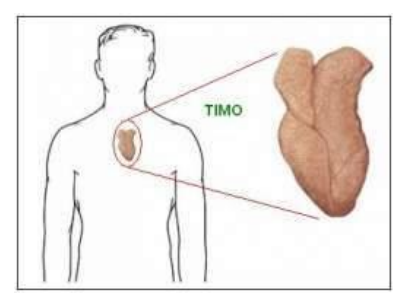

El timo es un órgano hematopoyético y endocrino de carácter temporal, que deja de crecer durante la pubertad y luego empieza a disminuir de tamaño; pesa $15 \mathrm{~g}$ al nacimiento, $35 \mathrm{~g}$ a la pubertad, $25 \mathrm{~g}$ a los veinticinco años, menos de $15 \mathrm{~g}$ a los sesenta años y $6 \mathrm{~g}$ a los setenta. Morfológicamente, tiene -durante la época en que es más activo- dos lóbulos laterales en estrecho contacto con la línea media, situado en parte en el tórax y en parte en el cuello, y se extiende desde el cuarto cartílago costal hacia arriba, hasta el borde inferior de la glándula tiroides. Está detrás del esternón y arriba del pericardio, separado del aórtico y de los grandes vasos por una fascia. Es de color gris rosado, blando y de superficie lobulada y estructura aplanada. Cada lóbulo lateral se compone de numerosos lóbulos unidos entre sí por un tejido fino, encontrándose toda la glándula envuelta en una cápsula un poco más densa. Los lóbulos de diferentes tamaños- están constituidos por nodulitos o folículos de uno a dos milímetros de diámetro, que tienen una porción cortical conformada por células linfoides y otra medular, con menos células linfoides y los corpúsculos concéntricos de Hassall. Cada folículo está rodeado de un plejo vascular.

Los linfocitos que pasan por el timo se transforman en células $T$, cuyo desarrollo y diferenciación son estimulados por las hormonas tímicas o timosinas; entre estas se conocen la fracción 5 de la limosina (TF5) -un extracto del timo que contiene cuarenta o más péptidos relacionados que son las llamadas timosinas, la timopentina (TP5), la protimosina I (ProTI), la timosina I (TI), las timosinas 7, 3 y 4 (T4), gen de la timosina 


\section{Sistema Genito - Urinario y Endocrino}

10, la timosina 10 y la I5, y el factor humoral tímico gama 2 (THF-2). Otra es la timopoyetina, que tiene un fragmento activo llamado timopentina, que baja los niveles del anterior péptido y reduce las respuestas endocrinas y de conducta durante el estrés experimental; el estrés contribuye a la depresión y durante esta enfermedad hay una hiperactividad del eje hipotálamo-hipófisis-suprarrenales. (HIDALGO, 20I I)

En las últimas décadas se ha conformado un concepto fisiológico unificado de la regulación hormonal de la respuesta inmunitaria. A partir de las células madre hematopoyéticas, los linfocitos $\mathrm{T}$ inmuno-competentes se produce en el timo. Este proceso es complejo requiere interacciones directas célula a célula, mediadas por receptores- e información paracrina a través de citoquinas y de hormonas tímicas.

Estas son polipéptidos localizados en las células retículo-epiteliales e in situ inducen la diferenciación de las células $T$, su expresión y funciones. Varios factores tímicos específicos y otras moléculas intervienen en dicha maduración; la fracción 5 de la timosina y sus péptidos constituyentes influencian varias propiedades de los linfocitos como los niveles de nucleótidos cíclicos, la producción de factor inhibitorio de la migración, la producción de anticuerpos T-dependientes y la expresión de varios marcadores de superficie celular, de maduración y de diferenciación. Varias neoplasias producen limosinas, cuya medición sirve para la detección del tumor. En estudios clínicos se ha visto que las hormonas tímicas fortalecen los efectos de los inmuno-moduladores en la inmunodeficiencia, enfermedades auto-inmunes y en cánceres. Los tratamientos oncológicos quimo-inmuno-terapéuticos combinados parecen ser más efectivos que la simple quimoterapia, reduciéndose también, de esta manera, la toxicidad hematopoyética. Las hormonas tímicas aumentan las linfoquinas, seúales inmunológicas clave que incluyen la interleukina 2 (IL-2), interferones, factores estimulantes de colonias y otros. Las limosinas logran que los linfocitos $\mathrm{T}$ desarrollen más rápidamente receptores para IL-2, lo que permite una rápida proliferación y activación de las células blancas para combatir gérmenes invasores.

Pueden prevenir la pérdida catabólica de tejido, como ocurre en el Sida y reducir 


\section{Sistema Genito - Urinario y Endocrino}

reacciones auto-inmunes como las que ocurren en la artritis reumatoide, previenen la lesión medular tóxica causada por la radioterapia y quimioterapia del cáncer, pueden aumentar ciertos anticuerpos necesarios para combatir algunas enfermedades, pero también reducir los niveles de la IgE en pacientes con rinitis alérgica, asma y dermatitis atípica. Con la mayor edad hay disminución de las hormonas tímicas; por ejemplo, entre los veinte y los cuarenta años caen los niveles de timosina y los de timulina -una hormona tímica activada por zinc- caen también en personas sanas que envejecen y en pacientes hipotiroideos. Es interesante observar que hay un cierto paralelismo de las hormonas tímicas con la hormona del crecimiento, a través de las células $\mathrm{T}$ que segregan tanto esta hormona como la $\mathrm{GH}-\mathrm{RH}$, y en experimentos en los que se remueve el timo se produce una degeneración de los somatotrofos hipofisiarios.

\section{Ovarios y testículos}

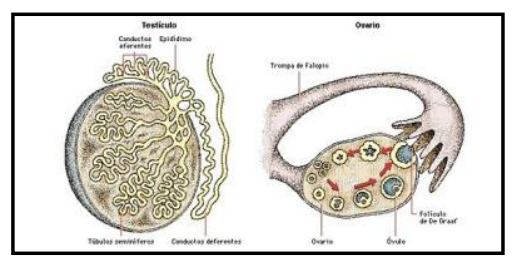

Las gónadas son los órganos que producen los gametos: espermatozoides en los hombres y ovocitos en las mujeres. Además de su función reproductiva, las gónadas secretan hormonas.

En los individuos las gónadas masculinas, o los testículos (pronunciado: TES-teez), se localizan en el escroto. Ellos secretan hormonas llamadas andrógenos (pronunciado: ANdruh-junz), el más importante de los cuales es la testosterona (pronunciado: tess-TOSStuh-rone). Estas hormonas dicen el cuerpo de un individuo cuando es hora de hacer los cambios asociados con la pubertad, como crecimiento del pene y de la altura, extensión de la voz, y crecimiento en pelo facial y púbico. Trabajando con hormonas de la glándula pituitaria, la testosterona también le dice al cuerpo de un individuo cuando es el momento de producir espermatozoides en los testículos.

Los ovarios, cuerpos ovalados pares localizados en la cavidad pelviana femenina, producen diversas hormonas esteroideas incluyendo 2 estrógenos (estradiol y estrona) y progesterona. Estas hormonas sexuales femeninas, junto con la FSH y la $\mathrm{LH}$ de la 


\section{Sistema Genito - Urinario y Endocrino}

adenohipófisis, regulan el ciclo menstrual, mantienen el embarazo y preparan las glándulas mamarias para la lactancia. También promueven el crecimiento de las mamas y el ensanchamiento de las caderas en la pubertad y ayudan a mantener estos caracteres sexuales secundarios. Los ovarios también producen inhibina, una hormona proteica que inhibe la secreción de la hormona foliculoestimulante (FSH).

Durante la pubertad, una niña experimentará el crecimiento del pecho, comenzará a acumular grasa corporal alrededor de las caderas y muslos, y tendrá un brote de crecimiento. El estrógeno y la progesterona también están involucrados en la regulación del ciclo menstrual de una niña. Estas hormonas también juegan un papel en el embarazo. Los ovarios y la placenta producen una hormona peptídica llamada relaxina (RLX), que aumenta la flexibilidad de la sínfisis del pubis durante el embarazo y ayuda a dilatar el cuello uterino durante el trabajo de parto y el nacimiento. Estas acciones ayudan a facilitar el pasaje del bebé, agrandando el canal de parto.

\section{Bloqueo de Receptores Hormonales.}

Los receptores hormonales son proteínas especiales que se encuentran en el interior y sobre la superficie de ciertas células del cuerpo, incluidas las células mamarias. Dichas proteínas tienen la función de ser ojos y oídos para las células, ya que reciben mensajes de sustancias que circulan por el torrente sanguíneo y les indican qué hacer. Todo informe patológico incluye los resultados de un análisis de receptores de hormonas, una prueba que indica si las células del cáncer de mama tienen o no receptores para las hormonas estrógeno y progesterona. Los receptores de hormonas son proteínas (ubicadas dentro y sobre las células mamarias) que reciben las señales hormonales que ordenan a las células multiplicarse.

Algunas hormonas sintéticas, que bloquean los receptores de algunas hormonas naturales, se utilizan como fármacos. Por ejemplo, el RU486 (mifepristona), usado para inducir abortos, se une a los receptores de progesterona (una hormona sexual femenina) y evita que ésta ejerza su efecto normal, en este caso, preparar el endometrio para la implantación. Cuando se administra RU486 a una mujer embarazada, las condiciones 


\section{Sistema Genito - Urinario y Endocrino}

necesarias en el útero para nutrir el embrión no pueden mantenerse, el desarrollo embrionario se detiene y el embrión es expulsado junto con el revestimiento uterino. Este ejemplo ilustra un importante principio endocrino: si se impide que una hormona interactúe con sus receptores, la hormona no puede desempeñar sus funciones normales. $\mathrm{Si}$ el cáncer posee receptores de estrógeno, se denomina receptor de estrógeno positivo (o RE+). Esto quiere decir que las células cancerígenas, al igual que las células mamarias normales, pueden recibir señales del estrógeno que estimulan su crecimiento. Si el cáncer posee receptores de progesterona, se denomina receptor de progesterona positivo (RP+). Nuevamente, esto quiere decir que las células cancerígenas pueden recibir señales de la progesterona que estimulan su crecimiento. Aproximadamente, dos de cada tres casos de cáncer de mama poseen receptores de hormonas positivos.

El análisis para la detección de receptores de hormonas es importante, ya que los resultados permiten determinar si es probable que el cáncer responda a la hormonoterapia u otros tratamientos. La hormonoterapia utiliza medicamentos que (I) reducen la cantidad de estrógeno en el cuerpo o (2) bloquean el estrógeno e impiden el crecimiento y funcionamiento de las células mamarias. Si las células del cáncer de mama poseen receptores de hormonas, estos medicamentos sirven para reducir e incluso detener su crecimiento. Pero si el cáncer es de tipo receptor de hormonas negativo (no hay receptores presentes), es probable que la hormonoterapia no funcione. Tú y tu médico deberán elegir otro tipo de tratamiento.

\section{Efecto diabetogénico de la hGH.}

Un síntoma del exceso de hormona de crecimiento humano $(\mathrm{hGH})$ es la hiperglucemia. La hiperglucemia persistente, a su vez, estimula al páncreas a secretar insulina en forma continua. Tal estimulación excesiva, si persiste por semanas o meses, puede causar “agotamiento de las células beta”, una gran disminución de la capacidad de las células beta del páncreas para sintetizar y secretar insulina. Por lo tanto, la secreción excesiva de hormona de crecimiento humano puede tener un efecto diabetogénico; esto es, causar diabetes mellitus (falta de actividad de la insulina). 


\section{Sistema Genito - Urinario y Endocrino}

Estudios que se han realizado últimamente han demostrado que los niveles excesivos de HGH pueden causar algunos problemas de salud bastante graves. La Hormona de Crecimiento Humano afecta muchas áreas del cuerpo, lo que incluye efectuar el mantenimiento y la función de los islotes pancreáticos. Cuando se usa de una manera correcta, la hormona del crecimiento humano probablemente no aumentará sus probabilidades de desarrollar diabetes. Pero, en realidad, no estamos hablando sobre el uso de la hormona de crecimiento humana de forma adecuada.

Administrado en dosis más altas, la hormona del crecimiento humano puede tener algunos efectos secundarios bastante positivos. Estos incluyen: reducción de la grasa corporal, aumento de la masa muscular, aumento de la energía, recuperación de la elasticidad en la piel, afectando positivamente el estado de ánimo general de una persona, capacidad de salud de una lesión más rápida y la capacidad de combatir enfermedades comunes de manera más efectiva.

Junto con lo bueno viene lo malo. Aquí hay algunos posibles efectos secundarios negativos de la $\mathrm{HGH}$ cuando se administra en dosis más altas: tumores de la pituitaria, engrosamiento de los huesos en la mandíbula, dedos de los pies y el dedo conocido como acromegalia que, a su vez, causa problemas propios, debilidad muscular, RESISTENCIA A LA INSULINA, DIABETES TIPO 2, agrandamiento del corazón y reducción de la función sexual. Esos son algunos efectos secundarios negativos muy graves causados por HGH. Por no hablar de todos los malos sentimientos que la gente tendrá hacia ti por alguna razón, como todas las celebridades que toman la controversia $\mathrm{HGH}$.

El uso excesivo de la hormona del crecimiento humano no solo es utilizado por celebridades y atletas profesionales. Los culturistas han estado utilizando HGH durante años para aumentar su ganancia muscular y los aspectos antienvejecimiento de la $\mathrm{HGH}$ se han ido apoderando últimamente de los incendios forestales. Supongo que no es tan sorprendente teniendo en cuenta que la última gran locura fue inyectar botulismo en las "áreas problemáticas" de tu rostro para paralizar el músculo y crear una apariencia más suave ... ¿Botox a alguien? En una época en que la diabetes ha alcanzado proporciones casi 


\section{Sistema Genito - Urinario y Endocrino}

epidémicas, es alarmante para mí ver que hay personas que aumentan voluntariamente sus posibilidades de desarrollar diabetes, ya sea por fama, profesión o vanidad.

\section{Hiperplasia suprarrenal congénita}

La hiperplasia suprarrenal congénita es un grupo de trastornos autosómicos recesivos que resultan de la deficiencia de una de las enzimas necesarias para la síntesis de cortisol en la corteza suprarrenal. El más frecuente es la deficiencia de esteroide 2I-hidroxilasa, que representa más del 90 por ciento de los casos. Este artículo analiza los mecanismos moleculares, el diagnóstico y el tratamiento de esta enfermedad y destaca los nuevos desarrollos, incluidas las correlaciones genotipo-fenotipo, el diagnóstico prenatal específico del gen y la terapia prenatal. La hiperplasia suprarrenal congénita (HSC) es un trastorno genético en el cual una o más enzimas necesarias para la síntesis de cortisol están ausentes. Debido a que el nivel de cortisol es bajo, la secreción de ACTH por la adenohipófisis es alta por falta de retroalimentación negativa.

La ACTH, a su vez, estimula el crecimiento y la actividad secretora de la corteza suprarrenal. Como resultado, las dos glándulas suprarrenales se agrandan. Sin embargo, ciertos pasos de la síntesis de cortisol están bloqueados. De esta manera, se acumulan moléculas precursoras y algunas de éstas son andrógenos débiles que pueden sufrir conversión a testosterona. El resultado es la virilización (virilismo) o masculinización. En la mujer, las características viriles incluyen el crecimiento de la barba, desarrollo de una voz más grave y una distribución masculina del vello, agrandamiento del clítoris de manera que se asemeja un pene, atrofia de las mamas y aumento de la musculatura que produce un físico masculino.

En los hombres prepúberes, el síndrome causa las mismas características que en las mujeres, más un rápido desarrollo de los órganos sexuales masculinos y la aparición del deseo sexual. En los hombres adultos, los efectos virilizantes de la HSC, por lo general, son ocultados por los efectos virilizantes normales de la testosterona secretada por los testículos. Como resultado, la HSC es a menudo difícil de diagnosticar en los hombres adultos. El tratamiento incluye terapia con cortisol, que inhibe la secreción de ACTH y así 


\section{Sistema Genito - Urinario y Endocrino}

reduce la producción de andrógenos suprarrenales.

\section{Trastorno afectivo estacional}

El trastorno afectivo estacional (seasonal affective disorder, SAD) es un tipo de depresión que afecta a algunas personas durante los meses del invierno, cuando el día es corto. Se piensa que se debe, en parte, a la sobreproducción de melatonina. Afectivo Emocional no son del todo claras, pero es bien sabido que la falta de luz solar juega un papel muy importante en ambas condiciones. Se cree que la cantidad de luz que recibe el cuerpo afecta a algunas hormonas y sustancias químicas específicas, como la melanina o la serotonina, además de a una parte del cerebro llamada hipotálamo. El hipotálamo controla la temperatura, hambre, sed, algunos aspectos del comportamiento y el sueño. Mientras los días se acortan y la cantidad de luz solar a la que nos exponemos se ve reducida, estas características cambian. El hipotálamo también controla los ritmos cardiacos, o el reloj corporal, provocando síntomas similares a los del jet lag, fatiga o agotamiento.

La terapia con luz brillante de espectro total (dosis repetidas de varias horas de exposición a luz artificial tan brillante como la luz solar) proporciona alivio a algunas personas. De 3 a 6 horas de exposición a la luz brillante también parece acelerar la recuperación del jet lag, el cansancio sufrido por los viajeros que cruzan varios husos horarios en poco tiempo.

\section{Trastornos de la glándula hipófisis.}

Los trastornos hipofisarios o pituitarios se caracterizan por un exceso o un déficit de una o varias de las hormonas sintetizadas por la glándula pituitaria. La pituitaria es una glándula del tamaño de un guisante localizada en el centro de la cabeza, detrás de la cavidad nasal, en la parte inferior del cerebro, justo por debajo del hipotálamo. El hipotálamo y la pituitaria forman parte del sistema endocrino, y ambos actúan conjuntamente en la síntesis y regulación de las hormonas que ejercen su acción sobre tejidos de todo el organismo. El hipotálamo, en comunicación con el cerebro y el sistema nervioso, detecta las necesidades del organismo para una determinada hormona y envía una señal a la hipófisis para que ésta aumente o disminuya la síntesis de determinadas hormonas.

Enanismo hipofisario, gigantismo y acromegalia. Varios trastornos de la adenohipófisis 


\section{Sistema Genito - Urinario y Endocrino}

anterior involucran a la hormona de crecimiento humano $(\mathrm{hGH})$. La hiposecreción de hGH disminuye el crecimiento óseo, y las epífisis se cierran antes de que se alcance la estatura normal. Este trastorno se llama enanismo hipofisario. Otros órganos del cuerpo también fallan en su crecimiento y las proporciones corporales son infantiles. El tratamiento requiere la administración de hGH durante la niñez, antes de que se cierren las epífisis. La hipersecreción de hGH durante la niñez causa gigantismo, un aumento anormal de la longitud de los huesos largos. La persona crece y se vuelve muy alta, pero las proporciones corporales son casi normales.

La hipófisis o pituitaria está formada por una porción anterior y una posterior que producen hormonas distintas. En la hipófisis anterior, se sintetiza la hormona del crecimiento $(\mathrm{GH})$, la adrenocorticotropina $(\mathrm{ACTH})$, la hormona estimulante del tiroides (TSH), la hormona luteinizante (LH), la hormona folículoestimulante (FSH) y la prolactina. Estas hormonas intervienen en la regulación del crecimiento óseo, de la masa muscular, de la respuesta del organismo al estrés, de los niveles de glucosa en sangre, de la velocidad de utilización de la energía por el organismo (tasa metabólica), del desarrollo de las características sexuales secundarias, de la fertilidad y de la producción de leche. Actúan sobre tejidos "diana" del organismo, incluyendo la glándula tiroides, las glándulas suprarrenales o adrenales, los ovarios (en las mujeres) y los testículos (en los varones).

Los gemelos idénticos; un hermano desarrolló gigantismo debido a un tumor hipofisario. La hipersecreción de hGH durante la adultez se llama acromegalia. Como la hGH no puede producir el alargamiento de los huesos largos porque las epífisis ya están cerradas, los huesos de las manos, los pies, las mejillas y la mandíbula se engrosan y otros tejidos se agrandan. Además, los párpados, los labios, la lengua y la nariz se agrandan y la piel se hace más gruesa y forma arrugas, especialmente, en la frente y las plantas de los pies.

\section{Diabetes insípida.}

La anormalidad más comúnmente asociada con la disfunción de la neurohipófisis es la diabetes insípida. Este trastorno se debe a defectos en los receptores de la hormona antidiurética (HAD o a una incapacidad para secretarla). La diabetes insípida neurogénica resulta de la hiposecreción de HAD causada, en general, por un tumor cerebral, 


\section{Sistema Genito - Urinario y Endocrino}

traumatismo de cráneo o cirugía cerebral que daña la neurohipófisis o el hipotálamo. En la diabetes insípida nefrogénica, los riñones no responden a la HAD. Los receptores de HAD pueden ser no funcionales, o los riñones pueden estar dañados.

Un síntoma común de ambas formas de DI es la excreción de grandes volúmenes de orina, con la deshidratación y sed resultantes. Es común que los niños afectados mojen la cama. Debido a que se pierde tanta agua en la orina, una persona con DI puede morir de deshidratación si se la priva de agua durante solo un día o dos. Durante el día, los riñones filtran toda la sangre muchas veces. Normalmente, la mayor parte del agua se reabsorbe y solo se elimina una pequeña cantidad de orina concentrada. La DI ocurre cuando los riñones no pueden concentrar la orina normalmente y se elimina una gran cantidad de orina diluida.

La cantidad de agua eliminada en la orina es controlada por la hormona antidiurética (HAD). La HAD también se conoce como vasopresina. La HAD se produce en una región del cerebro llamada hipotálamo. Luego se almacena y se secreta desde la hipófisis. Esta es una pequeña glándula ubicada justo debajo de la base del cerebro. La DI causada por falta de HAD se denomina diabetes insípida central. Cuando la DI es ocasionada por la insuficiencia del riñón para responder a la HAD, la afección se denomina diabetes insípida nefrógena. Nefrógena significa relacionada con el riñón

\section{Trastornos de la glándula tiroides}

Se sitúan entre los trastornos más comunes. Estos trastornos afectan, principalmente, a todos los aparatos y sistemas.

\section{Hipertiroidismo}

El hipertiroidismo o secreción excesiva de hormonas tiroideas aumenta de forma importante la tasa metabólica. Muchos de los nutrientes se queman en las células con rapidez excesiva y los pacientes sufren pérdida de peso, irritabilidad y aumento del apetito; muchas veces muestran protrusión de los ojos, debida en parte a edema de los tejidos retrooculares.

Teniendo en cuenta lo anteriormente mencionado, el hipertiroidismo se divide en varios 


\section{Sistema Genito - Urinario y Endocrino}

grados que son primarios y secundarios. Este último grado muestra anomalías que producen una cantidad muy elevada de TSH. Las de primer grado destacan la supresión de TSH y la elevación de sustancia importantes para el cuerpo.

\section{Hipertiroidismo primario}

El exceso de HT se debe a una enfermedad primaria del tiroides, con lo que estas se elevan en sangre y suprimen la producción de TSH. Las enfermedades pueden ser:

I. Enfermedad e Graves-Basedow: Una enfermedad de etiología autoinmunitaria en la que se producen inmunoglobulinas contra el receptor de la TSH que estimula la producción de HT y el crecimiento difuso del tiroides. Los anticuerpos estimulan continuamente la glándula tiroides a crecer y producir hormonas tiroideas. Un signo primario es una tiroides agrandada, que puede tener dos o tres veces su tamaño normal. Los pacientes con Graves tienen a menudo un edema peculiar detrás de los ojos, llamado exoftalmos, que hace que los ojos protruyan hacia afuera.

El tratamiento puede incluir resección quirúrgica de parte o de toda la glándula tiroides (tiroidectomía), uso de yodo para destruir en forma selectiva el tejido tiroideo y uso de fármacos asteroideos para bloquear la síntesis de hormonas tiroideas.

2. Adenoma tiroideo toxico o enfermedad de Plummer: Es un tumor benigno del tiroides que se manifiesta como un nódulo único que produce HT en exceso. El resto de la tiroides se atrofia al suprimirse la producción de TSH, la gammagrafía tiroidea muestra la presencia de un nódulo mientras que el resto de la tiroides no capta yodo.

3. Tiroiditis: se puede producir una tirotoxicosis por una brusca destrucción de la tiroides con la salida de las HT almacenada a la sangre, el tiroides inflamado no capta yodo radioactivo o lo capta escasamente.

4. Hipertiroidismo inducido por yodo: enfermedad de Jod-Basedow. Aparece al administrar yodo a pacientes con bocio multinodular cuya producción de HT era baja precisamente por la falta de yodo.

\section{Hipertiroidismo secundario}

Se produce por el exceso de TSH por adenomas hipofisiarios productores de TSH (muy 


\section{Sistema Genito - Urinario y Endocrino}

infrecuente).

\section{Hipertiroidismo por gonadotropina coriónica}

Los tumores trofoblásticos, como el coriocarcinoma, producen enormes cantidades de esta hormona, molecularmente emparentada con al TSH, que puede activar el receptor tiroideo normal de la TSH.

\section{Tirotoxicosis por secreción ectópica de HT}

Puede verse en el rarísimo struma ovárico (teratoma ovárico que tiene tejido tiroídeo funcional).

\section{Tirotoxicosis por ingestión de hormonas tiroideas en exceso}

Puede ser un efecto buscado por el médico, puede deberse a error en la dosis o a la ingestión de HT con fines manipulativos $y$, en alguna ocasión, a la ingestión de hamburguesas con tejido tiroideo.

\section{Hipotiroidismo}

La falta de HT produce enlentecimiento general del metabolismo, una disminución de la generación de calor y descenso en la síntesis proteica, pero con una disminución mayor del catabolismo que, de la síntesis de determinadas sustancias, tienden a acumularse (lípidos plasmáticos, mucopolisacáridos cutáneos). Muchas de las manifestaciones del hipotiroidismo, los fallos, se deben acción de las hormonas tiroideas y a la acumulación en los tejidos de una sustancia mucoide rica en ácido hialurónico. A esta manifestación se la denomina mixedema.

El hipotiroidismo congénito, la hiposecreción de hormonas tiroideas que está presente en el nacimiento, tiene consecuencias devastadoras si no se trata rápidamente. Antes llamada cretinismo, esta condición causa retardo mental severo e impide el crecimiento oseo. En el momento del nacimiento, él bebe es generalmente normal porque las hormonas tiroideas maternas liposolubles cruzaron la placenta durante el embarazo y permitieron el desarrollo normal. Si existe hipotiroidismo congénito, se debe empezar tratamiento oral con hormona tiroidea poco después del nacimiento y continuarlo de por vida.

Durante los años de la adultez se produce mixedema, la cual ocurre con una incidencia 


\section{Sistema Genito - Urinario y Endocrino}

casi cinco veces mayor en las mujeres que en los hombres. Una persona con mixedema tiene una frecuencia cardiaca baja, baja temperatura corporal, sensibilidad al frio, cabello y piel secos, debilidad muscular, letargo general y tendencia a aumentar de peso con facilidad. Debido a que el cerebro ya ha alcanzado la madurez, no hay retardo mental, pero la persona puede estar menos alerta. Las hormonas tiroideas por vía oral reducen los síntomas.

\section{Hipotiroidismo primario}

Se debe a una alteración primaria de la tiroides, que es incapaz de sintetizar HT. El descenso de la T4 circulante induce una elevación de la TSH plasmática. Es la forma más frecuente de hipotiroidismo, y puede ser congénito o adquirido.El hipotiroidismo congénito tiene como causas las anomalías de la embriogénesis del tiroides, anomalía en los genes de las proteínas implicadas en las síntesis de HT y el tratamiento con yodo o con antitiroideos durante el embarazo.

El hipotiroidismo adquirido tiene como causas la atrofia autoinmunitaria del tiroides (más frecuente), ausencia del tiroides por tratamiento con yodo radiactivo o cirugía, las tiroiditis, el hipotiroidismo por la deficiencia de yodo el hipotiroidismo inducido por yodo en pacientes con tiroiditis y el producido por fármacos.

\section{Hipotiroidismo secundario}

Es cualquier lesión hipofisiaria que impida la secreción de TSH. La TSH es indetectable. En general, a un hipotiroidismo menos marcado que el anterior ya que pude conservarse una cierta secreción tiroidea autónoma, independiente de TSH.

\section{Hipotiroidismo terciario}

Se refiere a la lesión hipotalámica que impide la secreción de TRH, aquí se puede detectar TSH en el plasma pero al no estar glucosada, es biológicamente inactiva

Hipotiroidismo por resistencia familiar a la acción de las HT

Debido a la mutación en el gen de los receptores tiroideos.

\section{Bocio}

Según, es simplemente una glándula tiroides agrandada. Puede asociarse con 


\section{Sistema Genito - Urinario y Endocrino}

hipertiroidismo, hipotiroidismo. Esto significa secreción normal de la hormona tiroidea. En algunos lugares del mundo, la ingesta de yodo de la dieta es inadecuada; el nivel bajo de hormona tiroidea en la sangre estimula la secreción de TSH, que causa el agrandamiento de la glándula tiroides.

I. Estimulación excesiva por la TSH, que origina en principio, un bocio difuso. Una estimulación crónicamente mantenida puede seleccionar diversos clones celulares con más capacidad de crecimiento lo que lleva a un bocio multinodular. El bocio endémico es debido a la deficiencia de yodo en la dieta y afecta a más de 200 millones de personas en el mundo

2. Estimulación por inmunoglobulinas que se unen al receptor tiroideo de la TSH y remedan sus efectos. Hay Ig que solo estimulan el crecimiento del tiroides, sin modificar su función, mientras que otras estimulan el crecimiento y la función, provocando hipertiroidismo

3. Crecimiento autónomo de las células foliculares. Puede manifestarse como una hiperplasia policlonal, que evoluciona a la multinodularidad. También puede aparecer un nódulo único monoclonal, benigno o maligno

4. El tiroides puede aumentar por causas inflamatorias (tiroiditis), infiltrantes (amiloidosis), tumorales (metástasis), o porque aparecen otras lesiones ocupantes de espacio (hemorragias, quistes, etc.).

\section{Trastornos de la glándula paratiroides}

\section{Hipoparatiroidismo}

Presenta una limitación de hormona paratiroidea que conduce a la deficiencia de $\mathrm{Ca} 2+$ sanguíneo, lo cual hace que las neuronas y las fibras musculares produzcan potenciales de acción en forma espontánea. Esto lleva a sacudidas, espasmos y tetania (contracción sostenida) del músculo esquelético. La causa principal del hipoparatiroidismo es la lesión accidental de las glándulas paratiroides o de su irrigación durante la tiroidectomía.

Síndromes de resistencia a la hormona paratiroidea o pseudohipoparatiroidismo 


\section{Sistema Genito - Urinario y Endocrino}

El pseudohipoparatiroidismo (ShPT) incluye varios procesos que tienen en común una resistencia a la acción de la PTH, lo que provoca un cuadro bioquímico indistinguible del hipoparatiroidismo auténtico (hipocalcemia e hiperfosfatemia), pero con aumento de la concentración sérica de PTH e hiperplasia de las paratiroides.

La PTH ejerce su efecto uniéndose a un receptor de la membrana celular, que está acoplado a una proteína G. Una vez formado el complejo receptor-PTH, la proteína G fija guanosina trifosfato (GTP), lo que le confiere capacidad para estimular la unidad catalítica de la adenilato ciclasa. Así se produce el $A M P c$, el típico, aunque no único, segundo mensajero de la PTH. El AMPc derivado de la acción de la PTH, activa toda una serie de enzimas que son las responsables de los efectos celulares de la PTH (por ejemplo, aumentar la fosfaturia). La proteína Gs (stimulating $\mathrm{G}$ protein) acoplada al receptor de la PTH está constituida por tres subunidades. La subunidad al fijar GTP se disocia de las otras subunidades y activa la adenilatociclasa.

\section{Hiperparatiroidismo}

Presenta un nivel elevado de hormona paratiroidea, se debe la mayoría de veces a un tumor en una de las glándulas paratiroides. Un nivel elevado de PTH provoca resorción excesiva de la matriz ósea, que aumenta los niveles sanguíneos de los iones de calcio y fosfato y hace que los huesos se tomen; también, promueve la formación de cálculos renales. En pacientes con hiperparatiroidismo se ve también fatiga, cambios en la personalidad y letargo.

\section{Hiperparatiroidismo primario (HPTP)}

Se da por el exceso de secreción de hormona paratiroidea, cantidad que está por encima a las necesidades de esta hormona para mantener la calcemia y la remodelación normal del hueso, lo que provoca hipercalcemia y trastornos óseos y renales en grado variable.Es una de las causas más frecuentes de hipercalcemia, con un espectro amplio de cifras de calcio, desde una elevación muy ligera, asintomática, hasta una grave muy sintomática.

\section{Hiperparatiroidismo secundario y terciario}

Diferente circunstancias de la vida diaria provocan un descenso mantenido de la calcemia 


\section{Sistema Genito - Urinario y Endocrino}

y desencadena una hiperfunción paratiroidea que intenta compensar la hipocalcemia (hiperparatiroidismo secundario). Las causas más frecuentes son la insuficiencia renal crónica y la hipovitaminosis D. En algunos casos se producen cambios en las paratiroides, de manera que éstas cada vez producen más exceso de PTH, lo que acaba originando hipercalcemia. Esta situación se denomina “hiperparatiroidismo terciario”.

\section{Hipercalcemia hipocalciúrica familiar (HHF)}

Se caracteriza por hipercalcemia e hipocalciuria relativa (la calciuria es baja para la hipercalcemia simultánea); asimismo, por cifras de PTH inapropiadamente normales o ligeramente elevadas; sin embargo, es de herencia autosómica dominante con muy alta penetrancia y puede ser responsable del $2 \%$ de los casos de las hipercalcemias asintomáticas. La mayoría de los casos ocurren por diversas mutaciones en el gen del sensor del calcio, que disminuyen la capacidad de las células paratiroideas para detectar la concentración extracelular de calcio, de manera que se mantienen unas cifras de calcio superiores a las normales. Además de la anomalía de las paratiroides, existe un aumento en la reabsorción tubular renal de calcio y magnesio. Este trastorno se localiza en el asa de Henle, y se debe a la disfunción del sensor del calcio en estas células, no al efecto de la PTH.

\section{Trastornos de la glándula suprarrenal}

\section{Síndrome de Cushing}

La hipersecreción de cortisol por la corteza suprarrenal produce síndrome de Cushing. Las causas incluyen un tumor de la glándula suprarrenal que secreta cortisol o un tumor en otro lado que secreta hormona adrenocorticotrófica (ACTH), estimulando la secreción excesiva de cortisol. Este trastorno se caracteriza por la degradación de las proteínas musculares y redistribución de la grasa corporal, que conduce a brazos y piernas extremadamente largas acompañados de una "cara de luna llena” redonda, "giba de búfalo" abdomen péndulo.

La piel de la cara está enrojecida, y en la piel que cubre el abdomen forma estrías. Se produce hematomas con facilidad y la cicatrización de heridas es inadecuada. El nivel 


\section{Sistema Genito - Urinario y Endocrino}

elevado de cortisol provoca hipoglucemia, osteoporosis, astenia, hipertensión, susceptibilidad aumentada de la infección, resistencia al estrés disminuida y cambios en el estado de ánimo. Las personas que necesitan tratamiento prolongado con glucocorticoides (por ej., para evitar el rechazo de un órgano trasplantado) pueden adquirir una apariencia de tipo cushingoide.

\section{Hipersecrecíon hipotalámicu de CRH}

De manera muy poco común, los pacientes con síndrome de Cushing presenta una hiperplasia difusa de las células coreticotrópicas hipotásrias que es la responsable de la hipersecreción de ACTH.

Es probable que la hiperplasia se deba a la hipersecreción de $\mathrm{CRH}$ por parte del hipotálamo o de tumores no hipotalámicos que secretan CRH ectópica. La hipersecreción crónica de CRII no ocasiona adenomas hipotirarios.

\section{Enfermedad de Addison.}

La enfermedad de Addison (insuficiencia adrenocortical crónica) es provocada por la hiposecreción de glucocorticoides y aldosterona. Son trastornos autoinmunitarios en los cuales los anticuerpos provocan la destrucción de la corteza suprarrenal o el bloqueo de la unión de la $\mathrm{ACTH}$ a sus receptores. Ciertos patógenos, como la bacteria que causa la tuberculosis, también pueden desencadenar la destrucción de la corteza suprarrenal.

Los síntomas, que normalmente no aparecen hasta que el $90 \%$ de la corteza suprarrenal ha sido destruido, incluyen letargo, anorexia, náuseas y vómitos, pérdida de peso, hipoglucemia y debilidad muscular. La pérdida de aldosterona lleva al aumento de potasio y la disminución de sodio en la sangre, tensión arterial baja, deshidratación, gasto cardíaco disminuido, arritmias y hasta paro cardíaco. La piel tiene un aspecto "bronceado" que a menudo se confunde con el bronceado por el sol. El tratamiento consiste en el reemplazo de los glucocorticoides y mineralocorticoides y el aumento de sodio en la dieta.

\section{Feocromacitomas}

Los feocromocitomas son muy pequeños. En general son tumores benignos de las células cromafines de la médula suprarrenal, producen hipersecreción de adrenalina y 


\section{Sistema Genito - Urinario y Endocrino}

noradrenalina. El resultado es una versión prolongada de la respuesta de lucha o huida: frecuencia cardíaca elevada, tensión arterial alta, niveles altos de glucosa en sangre y orina, un índice metabólico basal elevado (IMB), rubefacción, nerviosismo, sudoración y motilidad gastrointestinal disminuida. El tratamiento es la extirpación quirúrgica del tumor.

\section{Hiperproducción de esteroides androgénicos}

La hiperproducción de esteroides androgénicos (testosterona y hormonas similares) es un trastorno que causa virilización, es decir, el desarrollo de características masculinas exageradas, ya sea en los varones o en las mujeres. La hiperproducción moderada de andrógenos es frecuente, y tiene como único efecto un aumento del crecimiento del cabello (hirsutismo). La verdadera enfermedad virilizante es rara y sólo afecta de una a dos mujeres de cada 100 000. La incidencia de la enfermedad de virilización en los varones es prácticamente imposible de cuantificar.

\section{Hiperproducción de aldosterona}

La hiperproducción de aldosterona (hiperaldosteronismo) por parte de las glándulas suprarrenales es una enfermedad que modifica la concentración sanguínea de sodio, potasio, bicarbonato y cloro y, en consecuencia, produce hipertensión, causa debilidad y, en raras ocasiones, períodos de parálisis. La información que llega al riñón es trasmitida por la aldosterona, una hormona producida y secretada por las glándulas suprarrenales, para que excrete menos sodio y más potasio. Su secreción se halla regulada, en parte por la adrenocorticotropina de la hipófisis y en parte por un mecanismo de control en los riñones (el sistema renina-angiotensina- aldosterona). La enzima renina es producida en los riñones que controla la activación de la hormona angiotensina, la cual estimula, a su vez, las glándulas suprarrenales para producir aldosterona.

La causa del hiperaldosteronismo puede ser un tumor (por lo general no canceroso) en la glándula suprarrenal (el denominado síndrome de Conn), o bien otras enfermedades. Por ejemplo, las glándulas suprarrenales secretan grandes cantidades de aldosterona si la presión arterial es muy elevada o si se obstruye la arteria que transporta la sangre a los riñones. 


\section{Sistema Genito - Urinario y Endocrino}

\section{Trastornos de los islotes pancreáticos}

\section{Diabetes mellitus}

Se origina debido a la incapacidad de la insulina de promover el transporte de la glucosa hacia las células del cuerpo, puesto que el nivel de glucosa sanguínea es alto y la glucosa se pierde en la orina (glucosuria). La diabetes mellitus es la cuarta causa de muerte por enfermedad en los Estados Unidos, principalmente por su daño al aparato cardiovascular. Existen factores genéticos y ambientales que contribuyen a la aparición de los dos tipos de diabetes mellitus (de tipo I y de tipo 2).

\section{Diabetes de tipo I}

Diabetes de tipo I o también conocida como diabetes mellitus insulino-dependiente (IDDM), se ocasiona porque el sistema inmunitario de la persona destruye las células beta del páncreas, debido a esto se produce poco o nada de insulina.

La presencia de la IDDM es más común en personas menores de 20 años. El metabolismo celular de un diabético tipo I no tratado es similar al de una persona que sufre de inanición. Debido a que no hay insulina presente para contribuir a la entrada de glucosa a las células del organismo, la mayoría de las células usa ácidos grasos para producir ATP.

\section{Diabetes de tipo 2 o diabetes mellitus no insulino-dependiente (NIDDM),}

La diabetes de tipo 2 aparece más frecuentemente en personas obesas de más de 35 años. Sin embargo, el número de niños y adolescentes obesos con diabetes de tipo 2 está aumentando. Los síntomas clínicos son leves y los niveles altos de glucosa sanguínea, a menudo, pueden controlarse con dieta, ejercicio y disminución de peso.

\section{Cetoacidosis}

Este trastorno se debe al aumento de lascetonas, el cual hace que el pH sanguíneo baje. Puede producir la muerte sino es tratada a tiempo.

\section{Hiperinsulinismo}

El hiperinsulinismo, a menudo, aparece cuando un diabético se inyecta demasiada insulina. El síntoma principal es la hipoglucemia, nivel bajo de glucosa sanguínea, que ocurre debido a que el exceso de insulina estimula demasiado la captación de glucosa por las células del 


\section{Sistema Genito - Urinario y Endocrino}

cuerpo. La hipoglucemia resultante estimula la secreción de adrenalina, glucagón y hormona de crecimiento humano. Como consecuencia, aparecen ansiedad, sudoración, temblor, aumento de la frecuencia cardíaca, hambre y debilidad. Cuando la glucosa sanguínea cae, las células cerebrales se ven privadas del aporte de glucosa que necesitan para funcionar en forma efectiva.

La hipoglucemia grave produce desorientación mental, convulsiones, pérdida de la conciencia y shock. El shock producido por una sobredosis de insulina es conocido como shock insulínico. EL Shock insulínico oreacción insulinica ocurre cuando existe demasiada insulina en el cuerpo y este exceso reduce rápidamente el nivel de azúcar en sangre y las células cerebrales resultan afectadas. Una reacción insulínica puede ser causada por tomar mayores dosis de un medicamento, por dejar de comer, por ejercicio muy intenso y por factores emocionales.

La muerte puede ocurrir rápidamente, a menos que se eleve el nivel de glucosa. Clínicamente los diabéticos que están sufriendo una crisis de hiperglucemia o de hipoglucemia pueden tener síntomas muy parecidos: alteraciones mentales, coma, convulsiones y demás. El coma diabético ocurre cuando existe demasiado azúcar y muy poca insulina en sangre, y las células del cuerpo no reciben suficiente alimento.

El coma diabético puede ser ocasionado por comer demasiado azúcar, por no tomar los medicamentos prescriptos, por tensión y por una infección. Es importante identificar con rapidez la causa de los síntomas y tratarlos adecuadamente.

\section{Diagnóstico diferencial}

\section{Análisis FTA-ABS}

También conocida como prueba de absorción de anticuerpos treponémicos fluorescentes, es un análisis de sangre utilizado para detectar anticuerpos contra la bacteria Treponema pallidum que produce la sífilis. Este examen se utiliza para confirmar si una prueba de detección positiva para sífilis significa que hay una infección verdadera.

\section{Forma en que se realiza el análisis}

La sangre se extrae de una vena, usualmente, de la parte interior del codo o del dorso de 


\section{Sistema Genito - Urinario y Endocrino}

la mano. El sitio se limpia con un desinfectante (antiséptico). El médico coloca una banda elástica alrededor de la parte superior del brazo, con el fin de aplicar presión en el área y hacer que la vena se llene de sangre.

Luego, el médico introduce suavemente una aguja en la vena y recoge la sangre en un frasco hermético o en un tubo adherido a la aguja. La banda elástica se retira del brazo.

Una vez que se ha recogido la muestra de sangre, se retira la aguja y se cubre el sitio de punción para detener cualquier sangrado.

En bebés $o$ en niños pequeños, se puede utilizar un instrumento puntiagudo llamado lanceta para punzar la piel y hacerla sangrar. La sangre se recoge en un tubo pequeño de vidrio llamado pipeta, en un portaobjetos o en una tira reactiva. Finalmente, se puede colocar un vendaje sobre el área si hay algún sangrado.

\section{Preparación para el análisis}

No se requiere de preparación especial para este examen.

\section{Lo que se siente durante el análisis}

Cuando se inserta la aguja para extraer la sangre, se puede sentir un dolor moderado o sólo una sensación de pinchazo o picadura. Posteriormente, puede haber algo de sensación pulsátil.

\section{Razones por las que se realiza el análisis}

Este examen se utiliza de manera rutinaria para confirmar si una prueba de detección positiva para sífilis (ya sea el VDRL o RPR) refleja una infección real con sífilis. También, se puede realizar cuando se sospecha de sífilis primaria o terciaria y las pruebas de detección iniciales sean negativas, ya que dichas pruebas durante estas etapas de la sífilis pueden ser falsamente negativas.

\section{Los valores normales de análisis FTA-ABS}

Un resultado negativo o no reactivo significa que no existe infección presente ni pasada con sífilis.

\section{Significado de los valores anormales de análisis FTA-ABS}

Un FTA-ABS positivo, por lo general, indica infección con sífilis y es un resultado que 


\section{Sistema Genito - Urinario y Endocrino}

seguirá siendo positivo de por vida aún si esta enfermedad ha sido tratada en forma apropiada. Por lo tanto, no se puede utilizar para vigilar el tratamiento de la sífilis.

Otras enfermedades como el pian y la pinta también pueden producir resultados para FTA-ABS positivos. Ocasionalmente, puede haber un resultado falso positivo, con mayor frecuencia en las mujeres con lupus.

\section{Cuáles son los riesgos}

Las venas y las arterias varían en tamaño de un paciente a otro y de un lado del cuerpo a otro, razón por la cual extraer sangre de algunas personas puede ser más difícil que de otras.

Otros riesgos asociados con la extracción de sangre son leves, pero pueden ser:

-Sangrado excesivo

-Desmayo o sensación de mareo

-Hematoma (acumulación de sangre debajo de la piel)

-Infección (un riesgo leve cada vez que se presenta ruptura de la piel).

\section{Datos de laboratorio clínico}

Las pruebas de laboratorio clínico en el diagnostico endocrino se realizan para medir los niveles de hormonas en los fluidos corporales, los efectos de la hormona en células específicas, o las secuelas sistemáticas del proceso subyacente. Las pruebas se pueden realizar bajo condiciones aleatorias o basales, condiciones definidas con precisión, o en respuesta a algún estimulo provocado o sustituido. Al medir los niveles hormonales, la sensibilidad del análisis se refiere a las concentraciones más bajas de la hormona que puede ser detectado con precisión y, la especificidad alude a la extensión en el cual existen reacciones cruzadas que clasifican el estudio como inapropiado.

Hay pruebas complementarias para la valoración del eje hipotálamo-hipofisario, que se realizan mediante la determinación en suero de los niveles de cada hormona.

\section{Prueba de laboratorio}

\section{Eje hipotálamo- hipofisario anterior (adenohipófisis)}




\section{Sistema Genito - Urinario y Endocrino}

Las alteraciones de la regulación del eje hipotálamo-hipofisario anterior producen deficiencia o aumento en la función de cada uno de los órganos endocrinos donde se realiza su acción (tiroides, suprarrenales, gónadas).

\section{Examen para hormona del crecimiento (HC)}

Este examen mide la cantidad de hormona del crecimiento en sangre.

La glándula pituitaria produce hormona del crecimiento, lo que hace que un niño crezca. Esta glándula está localizada en la base del cerebro.

\section{Razones por las que se realiza el examen}

Esta hormona puede ser chequeada si el patrón de crecimiento de una persona es anormal o si se sospecha otra afección.

La presencia de demasiada hormona del crecimiento $(\mathrm{HC})$ puede causar aumento anormal en los patrones de crecimiento. En adultos, esto se llama acromegalia. En niños se llama gigantismo.

La presencia de muy poca hormona del crecimiento puede provocar una tasa invariable o lenta de crecimiento en niños. En adultos puede causar cambios en la energía, la masa muscular, los niveles de colesterol y la fortaleza ósea.

El examen de HC se puede emplear para monitorear la respuesta al tratamiento de la acromegalia.

\section{Resultados normales}

Hombres: I a $9 \mathrm{ng} / \mathrm{mL}$

Mujeres: I a $16 \mathrm{ng} / \mathrm{mL}$

La $\mathrm{HC}$ es secretada en pulsos. El tamaño y la duración de los pulsos varían con el momento del día, la edad, y el género. Por esta razón, las mediciones de esta hormona al azar rara vez son útiles. Un nivel más alto puede ser normal si la sangre se extrajo durante un pulso. Un nivel más bajo puede ser normal si la sangre se extrajo hacia el final del pulso. La HC es más útil cuando se mide como parte de una prueba de estimulación o inhibición. 


\section{Sistema Genito - Urinario y Endocrino}

\section{Significado de los resultados anormales}

Un alto nivel de la hormona del crecimiento puede indicar:

-Demasiada hormona $\mathrm{HC}$ en adultos, llamada acromegalia (se realiza una prueba especial para confirmar el diagnóstico)

-Crecimiento anormal debido al exceso de HC durante la infancia, llamado gigantismo (se realiza una prueba especial para confirmar el diagnóstico)

-Resistencia a la HC

-Tumor de la hipófisis

-Un bajo nivel de hormona de crecimiento puede indicar:

-Crecimiento lento observado en la infancia o niñez, causado por bajos niveles de la HC (se realiza una prueba especial para confirmar el diagnóstico)

-Hipopituitarismo (funcionamiento bajo de la hipófisis).

\section{Examen para hormona Prolactina}

La prolactina es una hormona segregada por la hipófisis. Esta es una glándula pequeña que se encuentra en la base del cerebro. Regula el equilibrio de muchas hormonas en el organismo. La prolactina estimula el desarrollo mamario y la producción de leche en las mujeres. No existe una función normal conocida de la prolactina en los hombres. La prolactina generalmente se mide cuando se buscan tumores en la hipófisis y la causa de:

I. Producción de leche en las mamas que no tiene relación con un parto (galactorrea)

2. Disminución del deseo sexual (libido) en hombres y mujeres

3. Problemas para conseguir una erección en hombres

4. Incapacidad para quedar embarazada (infertilidad)

5. Períodos menstruales irregulares o ausentes (amenorrea).

\section{Resultados normales}

Los valores normales para la prolactina son los siguientes:

I. Hombres: menos de $20 \mathrm{ng} / \mathrm{dl}(425 \mathrm{mlU} / \mathrm{l})$

2. Mujeres que no estén embarazadas: 5 - $40 \mathrm{ng} / \mathrm{dl}$ (I 06 - $850 \mathrm{mUl} / \mathrm{l})$

3. Mujeres embarazadas: 80 - $400 \mathrm{ng} / \mathrm{dl}(\mathrm{I}, 700-8,500 \mathrm{mUl} / \mathrm{l})$. 


\section{Sistema Genito - Urinario y Endocrino}

\section{Significado de los resultados anormales}

Las personas con las siguientes afecciones pueden tener niveles altos de prolactina:

I. Lesión o irritación de la pared torácica

2. Enfermedad de una zona del cerebro llamada hipotálamo

3. La glándula tiroides no produce suficiente hormona tiroidea (hipotiroidismo)

4. Enfermedad renal

5. Tumor hipofisario que produce prolactina (prolactinoma)

6. Otros tumores y enfermedades de la hipófisis en la zona de la hipófisis.

\section{Eje hipotálamo- hipofisario posterior (neurohipófisis)}

Viene condicionada fundamentalmente por las alteraciones en la producción de ADH (hormona antidiurética). Los dos procesos que se relacionan con esta alteración son la diabetes insípida (déficit de $A D H$ ) y el síndrome de secreción inadecuada de antidiurética (SIADH) causado por el aumento de secreciones de la misma.

\section{Examen de hormona antidiurética en la sangre (HAD)}

Este examen mide la cantidad de hormona antidiurética (HAD) en la sangre.

\section{Razones por las que se realiza el examen}

La HAD es una hormona que se produce en una parte del cerebro llamada el hipotálamo. Luego se almacena y es segregada desde la hipófisis, una pequeña glándula en la base del cerebro. La HAD actúa sobre los riñones para controlar la cantidad de agua excretada en la orina. El examen de HAD en la sangre se realiza cuando se sospecha lo siguiente:

I. Acumulación de líquidos en el cuerpo que están causando inflamación o hinchazón (edema)

2. Cantidades excesivas de orina

3. Niveles bajos de sodio (sal) en la sangre

4. Sed intensa o incontrolable

5. Ciertas enfermedades afectan la secreción normal de HAD. Se deben hacer pruebas del nivel de HAD en la sangre para determinar la causa de la enfermedad. La HAD se puede medir como parte de una prueba de restricción hídrica para 


\section{Sistema Genito - Urinario y Endocrino}

encontrar la causa de una enfermedad.

\section{Resultados normales}

Los valores normales para HAD pueden fluctuar de I a $5 \mathrm{pg} / \mathrm{mL}$.

\section{Significado de los resultados anormales}

Un nivel superior a lo normal puede presentarse cuando se secreta demasiada HAD, ya sea del cerebro donde se produce 0 de otro lugar en el cuerpo. Esto se denomina síndrome de secreción inadecuada de hormona antidiurética (SIHAD). Las causas de SIHAD incluyen:

I. Lesión o traumatismo cerebral

2. Tumores cerebrales

3. Desequilibrio de líquidos después de cirugía

4. Infección cerebral o del tejido que rodea el cerebro

5. Infección en los pulmones

6. Cáncer pulmonar de células pequeñas

7. Accidente cerebrovascular.

Un nivel por debajo de lo normal puede indicar:

I. Daño a la hipófisis o al hipotálamo

2. Diabetes insípida. Una afección en la cual los riñones no son capaces de conservar el agua.

3. Sed excesiva (polidipsia)

4. Demasiado líquido en el cuerpo (sobrecarga de volumen).

\section{TIROIDES}

\section{Examen de T3}

La triyodotironina (T3) es una hormona tiroidea. Juega un papel importante en el control corporal del metabolismo (los muchos procesos que hace el cuerpo para funcionar). 


\section{Sistema Genito - Urinario y Endocrino}

\section{Razones por las que se realiza el examen}

Este examen se hace para evaluar la actividad tiroidea. El funcionamiento de la tiroides depende de la acción de la T3 y otras hormonas, incluidas la hormona estimulante de la tiroides (TSH) y la T4. El examen de T3 mide tanto la T3 que está unida a proteínas como la que está flotando libre en la sangre.

Se presenta signos de un trastorno tiroideo, como:

I. La hipófisis no produce cantidades normales de algunas o de todas sus hormonas

2. Hipertiroidismo

3. Hipotiroidismo.

\section{Resultados normales}

El rango para los valores normales es de 100 a $200 \mathrm{ng} / \mathrm{dL}$ o 1.54 a $3.08 \mathrm{nmol} / \mathrm{L}$

\section{Significado de los resultados anormales}

Un nivel de T3 por encima de lo normal puede ser un signo de:

I. Hipertiroidismo (por ejemplo, enfermedad de Graves)

2. Tirotoxicosis por T3 (poco común)

3. Bocio nodular tóxico

4. Tomar medicamentos o ciertos suplementos (común)

5. Enfermedad hepática.

Un nivel alto de T3 puede ocurrir con el embarazo o con el uso de píldoras anticonceptivas o estrógenos.

Un nivel por debajo de lo normal puede deberse a:

I. Enfermedad corta o prolongada

2. Tiroiditis (hinchazón o inflamación de la glándula tiroides: la enfermedad de Hashimoto es el tipo más común)

3. Inanición

4. Hipotiroidismo.

\section{Examen de T4}




\section{Sistema Genito - Urinario y Endocrino}

La T4 (tiroxina) es la principal hormona producida por la glándula tiroides.

\section{Razones por las que se realiza el examen}

Se puede recomendar este examen si tiene signos de un trastorno de la tiroides, incluyendo:

I. Hallazgos anormales de otros análisis de tiroides, tales como TSH o T3

2. Síntomas de un hipertiroidismo

3. Síntomas de un hipotiroidismo

4. Hipopituitarismo (la hipófisis no produce suficiente cantidad de sus hormonas)

5. Bultos o nódulos en la tiroides

6. Glándula tiroides agrandada o irregular

7. Problemas para quedar embarazada.

Este examen también se usa para monitorear a personas que están siendo tratadas por problemas de tiroides.

\section{Resultados normales}

Un rango normal y típico va de 4.5 a II.2 $\mu \mathrm{g} / \mathrm{dL}$ o 57919.50 a I44I55.20 pmol/L).

\section{Significado de los resultados anormales}

Para entender completamente los resultados de un examen de T4 libre, se pueden necesitar los resultados de otros exámenes de sangre de tiroides, tales como TSH o T3.

Los resultados de los exámenes también pueden ser afectados por el embarazo, el nivel de estrógeno, los problemas hepáticos, enfermedades más graves que afectan a todo el cuerpo, y cambios hereditarios en una proteína que se una a la T4. Los niveles de T4 superiores a lo normal pueden deberse a afecciones que involucran una hiperactividad de la tiroides, como:

I. Enfermedad de Graves 


\section{Sistema Genito - Urinario y Endocrino}

2. Tomar mucho medicamento de hormona tiroidea

3. Tiroiditis

4. Bocio tóxico o nódulos de la tiroides tóxicos

5. Algunos tumores de los testículos o los ovarios (raro)

6. Tener pruebas de imágenes con medios de contraste que contengan yodo (raro, y sólo si hay un problema con la tiroides)

7. Comer muchas comidas que contengan yodo (muy raro, y sólo si hay un problema con la tiroides)

8. Los niveles de T4 inferiores a lo normal pueden deberse a:

9. Hipotiroidismo (lo que incluye enfermedad de Hashimoto y otros trastornos que involucran hipoactividad de la tiroides)

10. Enfermedad aguda severa

II. Desnutrición o ayuno

12. Uso de ciertos medicamentos.

\section{Examen de la hormona estimulante de la tiroides (TSH)}

El TSH es un examen que mide la cantidad de la hormona estimulante de la tiroides (TSH, por sus siglas en inglés) en la sangre. Esta hormona es producida por la hipófisis. Le ordena a la glándula tiroides producir y secretar las hormonas tiroideas en la sangre.

\section{Razones por las que se realiza el examen}

Su proveedor ordenará este examen si usted tiene signos o síntomas de hipertiroidismo o hipotiroidismo. También se utiliza para vigilar el tratamiento de estas afecciones.

\section{Resultados normales}

Los valores normales pueden fluctuar de 0.4 a $4.0 \mathrm{mlU} / \mathrm{L}$

Los valores de TSH pueden variar durante el día. Es mejor hacerse la prueba temprano a la mañana.

I. Los expertos no están de acuerdo completamente sobre cuál debería ser el número más alto. Las opiniones varían de 2.5 a $4.0 \mathrm{mlU} / \mathrm{L}$ 


\section{Sistema Genito - Urinario y Endocrino}

2. Si usted está en tratamiento por un trastorno tiroideo, el nivel de la hormona estimulante de la tiroides probablemente se mantendrá entre 0.5 y $4.0 \mathrm{mlU} / \mathrm{L}$, excepto cuando:

3. La causa del problema es un trastorno de la hipófisis. Se puede esperar un TSH bajo

4. Alguien que haya sido tratado por cáncer de tiroides. Un nivel de TSH bajo puede ser mejor para prevenir que el cáncer de tiroides reaparezca

5. Una mujer está embarazada. El rango normal de TSH es diferente para las mujeres que están embarazadas. Su proveedor puede sugerir que tome hormona tiroidea, incluso si su TSH está en el rango normal.

\section{Significado de los resultados anormales}

Los niveles de TSH por encima de lo normal casi siempre se deben a una glándula tiroideshipoactiva (hipotiroidismo). Hay muchas causas de este problema.

Los niveles por debajo de lo normal pueden deberse a una glándula tiroides hiperactiva, que puede ser causada por:

I. Enfermedad de Graves

2. Bocio nodular tóxico o bocio multinodular

3. Demasiado yodo en el cuerpo (debido al hecho de recibir un medio de contraste yodado empleado durante exámenes imagenológicos, como una tomografía computarizada TC)

4. Tomar demasiado medicamento para la hormona tiroidea o suplementos recetados o de venta libre que contengan hormona tiroidea.

El uso de ciertos medicamentos, por ejemplo, glucocorticoides/esteroides, dopamina, ciertos fármacos quimioterapéuticos y analgésicos opiáceos como la morfina, también puede causar un nivel de TSH inferior a lo normal.

\section{Anticuerpos microsómicos antitiroideos (ANTI TPO)}

Los microsomas se encuentran dentro de las células de la tiroides. El cuerpo produce anticuerpos para microsomas cuando se ha producido daño en las células de la 


\section{Sistema Genito - Urinario y Endocrino}

tiroides. El examen de anticuerpos microsómicos antitiroideos mide estos anticuerpos en la sangre.

\section{Razones por las que se realiza el examen}

Este examen se realiza para confirmar la causa de problemas de la tiroides, entre ellos tiroiditis de Hashimoto.

El examen también se emplea para averiguar si un trastorno autoinmunitario o inmunitario está causando daño a la tiroides.

\section{Resultados normales}

I. Negativos: $<35 \mathrm{U} / \mathrm{ml}$

2. Indeterminados: $35-50 \mathrm{U} / \mathrm{ml}$

3. Positivos: $>50 \mathrm{U} / \mathrm{ml}$.

\section{Significado de los resultados anormales}

Un resultado positivo puede deberse a:

I. Tiroiditis granulomatosa

2. Tiroiditis de Hashimoto.

Los altos niveles de estos anticuerpos también han sido vinculados a un mayor riesgo de:

I. Aborto espontáneo

2. Preeclampsia

3. Nacimiento prematuro

4. Fracaso de una fecundación in vitro.

Importante: un resultado positivo no siempre quiere decir que tiene una afección tiroidea o que necesita tratamiento para su tiroides. Un resultado positivo puede significar que tiene una posibilidad mayor de desarrollar enfermedad de la tiroides en el futuro.

Se pueden observar anticuerpos antimicrosomales en la sangre si tiene otros trastornos 


\section{Sistema Genito - Urinario y Endocrino}

autoinmunitarios, incluyendo:

I. Anemia hemolítica autoinmunitaria

2. Hepatitis autoinmunitaria

3. Enfermedad suprarrenal autoinmunitaria

4. Artritis reumatoidea

5. Síndrome de Sjogren

6. Lupus eritematoso sistémico.

\section{Examen de hormona paratiroidea (PTH) en la sangre}

PTH corresponde a hormona paratiroidea. Es una hormona proteica secretada por la glándula paratiroides.

\section{Razones por las que se realiza el examen}

La hormona paratiroidea (PTH) es secretada por las glándulas paratiroides. Las 4 pequeñas glándulas paratiroides están localizadas en el cuello, cerca de o adheridas al lado posterior de la glándula tiroides. La glándula tiroides está localizada en el cuello, justo arriba del lugar en el que las clavículas se juntan.

La PTH controla los niveles de calcio, fósforo y vitamina $D$ en la sangre. Es importante para regular el crecimiento de los huesos. Se realiza cuando:

I. Tiene un nivel alto de calcio o un nivel bajo de fósforo en la sangre

2. Tiene osteoporosis grave que no se puede explicar o no responde al tratamiento.

3. Tiene enfermedad renal

4. Para ayudar a entender si su PTH es normal, se medirá el calcio en la sangre al mismo tiempo.

\section{Resultados normales}

Los valores normales son de 10 a $55 \mathrm{pg} / \mathrm{mL}$. 


\section{Sistema Genito - Urinario y Endocrino}

\section{Significado de los resultados anormales}

Un nivel de la hormona paratiroidea por encima de lo normal puede presentarse con:

I. Trastornos que aumentan los niveles de fósforo o fosfato en la sangre, tales como la enfermedad renal crónica

2. Insuficiencia del organismo para responder a la PTH (seudohipoparatiroidismo)

3. Falta de calcio, que puede deberse a no consumir suficiente calcio, no absorberlo en el intestino o perder demasiado calcio en la orina

4. Embarazo o lactancia (poco común)

5. Hinchazón de las glándulas paratiroides, llamada hiperparatiroidismo primario

6. Tumores en la glándula paratiroides, llamados adenomas

7. Trastornos de la vitamina $D$, entre ellos insuficiente luz solar en adultos mayores $y$ problemas para absorber, descomponer y usar la vitamina $\mathrm{D}$ en el cuerpo.

8. Un nivel por debajo de lo normal puede ocurrir con:

9. Extirpación accidental de las glándulas paratiroides durante una cirugía de cuello

10. Destrucción autoinmunitaria de la glándula paratiroides

II. Cánceres que comienzan en otra parte del cuerpo (como la mama, los pulmones o el colon) y se propagan al hueso

12. Exceso de calcio durante un largo período de tiempo, generalmente, por exceso de suplementos de calcio o ciertos antiácidos que contienen carbonato de calcio o bicarbonato sódico (bicarbonato de sodio)

13. Glándulas paratiroides que no producen suficiente PTH (hipoparatiroidismo)

14. Bajos niveles de magnesio en la sangre

15. Radiación a las glándulas paratiroides

16. Sarcoidosis 


\section{Sistema Genito - Urinario y Endocrino}

17. Ingesta excesiva de vitamina D.

Otras afecciones para las cuales se puede ordenar este examen incluyen:

I. Neoplasia endocrina múltiple (NEM) I

2. Neoplasia endocrina múltiple (NEM) II.

\section{Glándulas suprarrenales}

\section{Examen de estimulación con corticotropina}

Es un análisis que mide la eficiencia con la cual las glándulas suprarrenales responden a la hormona corticotropina (ACTH, por sus siglas en inglés), una hormona producida en la hipófisis que estimula las glándulas suprarrenales para secretar una hormona llamada cortisol.

\section{Razones por las que se realiza el examen}

Este examen puede ayudar a determinar si las glándulas suprarrenales e hipofisarias están normales. Se utiliza con mayor frecuencia cuando el médico piensa que tiene un problema con las glándulas suprarrenales, como la enfermedad de Addison o la insuficiencia hipofisaria. También se usa para ver si sus glándulas hipofisarias y suprarrenales se han recuperado de un uso prolongado de glucocorticoides, como la prednisona.

\section{Resultados normales}

Un incremento en el cortisol después de la estimulación por medio de corticotropina (ACTH), es normal.

El nivel de cortisol después de la estimulación con corticotropina, debe ser mayor de 18 a $20 \mu \mathrm{g} / \mathrm{dL}$ ○ 496.58 a $55 \mathrm{I} .76 \mathrm{nmol} / \mathrm{L}$, según la dosis de ACTH empleada.

\section{Significado de los resultados anormales}

Este examen sirve para averiguar si usted tiene:

I. Insuficiencia suprarrenal aguda (afección potencialmente mortal que sucede cuando no hay suficiente cortisol)

2. Enfermedad de Addison (las glándulas suprarrenales no producen suficiente cortisol)

3. Hipopituitarismo (la hipófisis no está produciendo suficientes hormonas como la 


\section{Sistema Genito - Urinario y Endocrino}

corticotropina).

\section{Examen de aldosterona en la sangre}

La aldosterona también se puede medir mediante un examen de orina.

\section{Razones por las que se realiza el examen}

Este examen se solicita para las siguientes afecciones:

I. Ciertos trastornos de líquidos y electrólitos

2. Presión arterial difícil de controlar

3. Presión arterial baja al pararse (hipotensión ortostática).

La aldosterona es una hormona segregada por las glándulas suprarrenales y ayuda al cuerpo a regular la presión arterial. La aldosterona aumenta la reabsorción de sodio y agua y la liberación de potasio en los riñones. Esta acción eleva la presión arterial.

El examen de aldosterona en la sangre con frecuencia se combina con otros exámenes, como el examen de la hormona renina, con el fin de diagnosticar una producción excesiva o insuficiente de aldosterona.

\section{Resultados normales}

En suero o plasma tomados en paciente de pie fluctúan entre 4 a $31 \mathrm{mg} / \mathrm{dL}$ y acostado entre I a $16 \mathrm{ng} / \mathrm{dL}$. Con dieta normal los niveles en orina de 24 horas fluctúan entre 6 a 25 $\mathrm{Hg} / 24$ horas, pero están influenciados por la ingestión de sal. Con dieta baja de sal, se encuentran entre 17 a $44 \mathrm{ng} / 24$ horas y con dieta alta de sal entre 0 a $6 \mu \mathrm{\mu g} / 24$ horas.

I. Adultos: $7-30 \mathrm{ng} / \mathrm{dL}$

2. Adolescentes : $4-48 \mathrm{ng} / \mathrm{dL}$

3. Niños : $5-80 \mathrm{ng} / \mathrm{dL}$

4. Dietas bajas de sodio: Valores 3 - 5 veces más altas. 


\section{Sistema Genito - Urinario y Endocrino}

\section{Significado de los resultados anormales}

Un nivel de aldosterona más alto de lo normal puede deberse a:

I. Síndrome de Bartter (extremadamente raro)

2. Glándulas suprarrenales que secretan demasiada hormona aldosterona

3. (Hiperaldosteronismo primario, por lo regular, debido a un nódulo maligno en dicha glándula)

4. Dieta muy baja en sodio

5. Un nivel de aldosterona por debajo de lo normal puede deberse a:

6. Trastornos de las glándulas suprarrenales, incluso el hecho de no secretar suficiente aldosterona y una afección llamada insuficiencia suprarrenal primaria (enfermedad de Addison)

7. Dieta muy rica en sodio.

\section{Examen de eritropoyetina}

Es un examen que mide la cantidad de una hormona llamada eritropoyetina (EPO) en la sangre. Esta hormona ordena a las células madre de la médula ósea producir más glóbulos rojos. La EPO es producida por células del riñón. Estas células liberan más EPO cuando el nivel de oxígeno en la sangre está bajo.

\section{Razones por las que se realiza el examen}

Este examen se puede utilizar para ayudar a determinar la causa de anemia, policitemia (conteo alto de glóbulos rojos) u otros trastornos de la médula ósea.

Un cambio en los glóbulos rojos afectará la secreción de eritropoyetina. Por ejemplo, las personas con anemia tienen muy pocos glóbulos rojos, de manera que se produce más eritropoyetina.

\section{Resultados normales}

El rango normal es de 2.6 a $18.5 \mathrm{mU} / \mathrm{mL}$

Los ejemplos de arriba son mediciones comunes para los resultados de estos exámenes. Los rangos de los valores normales pueden variar ligeramente entre diferentes laboratorios. 


\section{Sistema Genito - Urinario y Endocrino}

\section{Significado de los resultados anormales}

El aumento en el nivel de EPO puede deberse a una policitemia secundaria. Esta es una producción excesiva de glóbulos rojos que ocurre en respuesta a un episodio, como un nivel bajo de oxígeno en la sangre. Esta afección puede ocurrir a grandes alturas $\circ$, rara vez, debido a un tumor que libera EPO.

Se puede observar un nivel de EPO por debajo de lo normal en la insuficiencia renal crónica, en la anemia por enfermedad crónica o en la policitemia vera.

\section{Examen de cortisol en la sangre}

El cortisol es una hormona esteroidea (glucocorticoide) producida por la glándula suprarrenal.

El cortisol también se puede medir mediante un examen de orina o de saliva.

\section{Razones por las que se realiza el examen}

El examen se hace para verificar si hay aumento o disminución de la producción de cortisol. El cortisol es una hormona glucocorticoide (esteroide) secretada desde la glándula suprarrenal en respuesta a la hormona llamada corticotropina (ACTH, por sus siglas en inglés). Es una hormona segregada desde la hipófisis en el cerebro.

El cortisol afecta muchos sistemas corporales diferentes y juega un papel en:

I. El crecimiento de los huesos

2. El control de la presión arterial

3. El funcionamiento del sistema inmunitario

4. El metabolismo de grasas, carbohidratos y proteínas

5. El funcionamiento del sistema nervioso

6. La respuesta al estrés.

Diversas enfermedades, como el síndrome de Cushing y la enfermedad de Addison, pueden llevar ya sea a demasiada o a muy baja producción de cortisol. La medición del nivel de cortisol puede ayudar a diagnosticar estas afecciones. También se mide para evaluar qué tan bien están funcionado la hipófisis y las glándulas suprarrenales. Otras afecciones por las que se puede llevar a cabo este examen incluyen: 


\section{Sistema Genito - Urinario y Endocrino}

I. Crisis suprarrenal aguda, una afección potencialmente mortal que sucede cuando no hay suficiente cortisol

2. Sepsis, una enfermedad en la cual el cuerpo tiene una respuesta severa a una bacteria u otros microbios

3. Presión arterial baja.

\section{Resultados normales}

Los valores normales de una muestra de sangre tomada a las 8 de la mañana son de 6 a 23 $\mu g / d L) \circ 165.53$ a $634.52 \mathrm{nmol} / \mathrm{L}$.

\section{Significado de los resultados anormales}

Un nivel más alto de lo normal puede indicar:

I. Enfermedad de Cushing: en la cual la hipófisis produce demasiada hormona corticotropina, debido al crecimiento excesivo de dicha glándula o a un tumor en ella

2. Síndrome de Cushing ectópico: en el cual un tumor por fuera de la hipófisis o las glándulas suprarrenales produce demasiada corticotropina

3. Tumor de la glándula suprarrenal que está produciendo demasiado cortisol

4. Un nivel por debajo de lo normal puede indicar:

5. Enfermedad de Addison, en la cual las glándulas suprarrenales no producen suficiente cortisol

6. Hipopituitarismo, en el cual la hipófisis no le da la señal a la glándula suprarrenal para producir suficiente cortisol

7. Inhibición del funcionamiento normal de la hipófisis o las glándulas suprarrenales por medio de medicinas glucocorticoides como píldoras, cremas para la piel, gotas para los ojos, inhaladores, inyecciones en las articulaciones, quimioterapia.

\section{Examen de renina en la sangre}

Los medicamentos que pueden afectar las mediciones de la renina incluyen:

I. Píldoras anticonceptivas

2. Medicamentos para la presión arterial 


\section{Sistema Genito - Urinario y Endocrino}

3. Medicamentos que dilatan los vasos sanguíneos (vasodilatadores). Por lo general, se emplean para tratar la hipertensión arterial o la insuficiencia cardíaca

4. Diuréticos

5. Consuma una alimentación equilibrada y normal con contenido moderado de sodio (no más de $3 \mathrm{gm} /$ día), durante 3 días antes del examen.

Tenga en cuenta que el nivel de renina puede verse afectado por el embarazo al igual que la hora del día y la posición del cuerpo al momento de tomarle la muestra de sangre.

\section{Razones por las que se realiza el examen}

La renina es una proteína (enzima) segregada por células renales especiales cuando usted tiene un nivel de sal (sodio) reducido o volemia baja.

$\mathrm{Si}$ usted padece hipertensión arterial, el médico puede solicitar un examen de aldosterona y renina para ayudar a determinar la causa de la presión sanguínea elevada. Los resultados del examen ayudan a guiar al médico en la elección del medicamento correcto.

\section{Resultados normales}

Los valores normales van de 0.2 a $3.3 \mathrm{ng} / \mathrm{mL} / \mathrm{hora}$ o 0.056 a $0.92 \mathrm{ng} / \mathrm{L} / \mathrm{s}$.

\section{Significado de los resultados anormales}

Los niveles altos de renina pueden deberse a:

I. Glándulas suprarrenales que no producen suficientes hormonas (enfermedad de Addison u otro tipo de insuficiencia suprarrenal)

2. Sangrado (hemorragia)

3. Insuficiencia cardíaca

4. Hipertensión arterial causada por el estrechamiento de las arterias renales (hipertensión renovascular)

5. Cicatrización del hígado y actividad hepática deficiente (cirrosis)

6. Pérdida de líquido corporal (deshidratación)

7. Daño renal que crea el síndrome nefrótico

8. Tumores renales que producen renina 


\section{Sistema Genito - Urinario y Endocrino}

9. Presión arterial muy alta y repentina (hipertensión maligna)

10. Los niveles bajos de renina pueden deberse a:

II. Glándulas suprarrenales que segregan demasiada hormona aldosterona (hiperaldosteronismo)

12. Hipertensión arterial que es sensible a la sal

13. Tratamiento con hormona antidiurética (HAD)

14. Tratamiento con esteroides que provoca que el cuerpo retenga sal.

\section{Función endocrina gonadal}

\section{Hormona Folículo estimulante FSH en la sangre}

En las mujeres, la FSH ayuda a controlar el ciclo menstrual y estimula a los ovarios para que produzcan óvulos. El examen se utiliza para ayudar a diagnosticar o evaluar:

I. Menopausia

2. Mujeres con poliquistosis ovárica, quistes ováricos

3. Sangrado menstrual o vaginal anormal

4. Problemas para quedar embarazada o esterilidad

En los hombres, la FSH estimula la producción de espermatozoides. El examen se utiliza para ayudar a diagnosticar o evaluar:

I. Problemas de esterilidad

2. Hombres que no tengan testículos o cuyos testículos estén subdesarrollados

3. En los niños, la FSH está involucrada con el desarrollo de características sexuales. El examen se ordena para niños:

4. Que presentan características sexuales a una edad muy temprana

5. Que se retrasan en el inicio de la pubertad.

\section{Resultados normales}

Los niveles normales de FSH diferirán dependiendo de la edad y el sexo de una persona. Hombres:

I. Antes de la pubertad: $0-5.0 \mathrm{mUl} / \mathrm{ml}$

2. Durante la pubertad: $0.3-10.0 \mathrm{mUl} / \mathrm{ml}$

3. Adultos: $1.5-12.4 \mathrm{mUl} / \mathrm{ml}$ 


\section{Sistema Genito - Urinario y Endocrino}

4. Mujeres:

5. Antes de la pubertad: $0-4.0 \mathrm{mUl} / \mathrm{ml}$

6. Durante la pubertad: $0.3-10.0 \mathrm{mUl} / \mathrm{ml}$

7. Mujeres que están menstruando: $4.7-21.5 \mathrm{mUl} / \mathrm{ml}$

8. Posmenopáusicas: 25.8 - $134.8 \mathrm{mUl} / \mathrm{ml}$.

\section{Significado de los resultados anormales}

Se pueden presentar niveles altos de FSH en las mujeres:

I. Durante o después de la menopausia, incluso en la menopausia prematura

2. Al recibir terapia hormonal

3. Debido a ciertos tipos de tumor en la hipófisis

4. Debido al síndrome de Turner

5. Los niveles bajos de FSH en las mujeres se pueden presentar debido a:

6. Tener un peso muy bajo o haber tenido una reciente pérdida de peso rápida

7. No producir óvulos (no ovular)

8. Partes del cerebro (la hipófisis o el hipotálamo) que no producen cantidades normales de todas o algunas de sus hormonas

9. Embarazo

10. Los altos niveles de FSH en los hombres pueden significar que los testículos no están funcionando correctamente debido a:

II. Edad avanzada (andropausia)

12. Daños en los testículos causados por el consumo excesivo de alcohol, quimioterapia o radiación

13. Problemas con los genes, como el síndrome de Klinefelter

14. Tratamiento con hormonas

15. Ciertos tumores en la hipófisis

16. Los niveles bajos de FSH en los hombres pueden significar que partes del cerebro (la hipófisis o el hipotálamo) no producen cantidades normales de todas o algunas de sus hormonas. 


\section{Sistema Genito - Urinario y Endocrino}

Los niveles altos de FSH en los niños o las niñas pueden significar que la pubertad está a punto de comenzar.

\section{Hormona Luteinizante LH}

En las mujeres, un incremento en el nivel de HL en la mitad del ciclo provoca la liberación de óvulos (ovulación). El médico ordenará este examen para ver si:

- Está ovulando, cuando se tiene problemas para quedar embarazada o tiene periodos que no son regulares

- Ha llegado a la menopausia.

Si es hombre, el examen se puede solicitar si tiene signos de esterilidad o baja libido. El examen se puede ordenar si usted tiene signos de un problema en la hipófisis.

\section{Resultados normales}

Los resultados normales para una mujer adulta son:

I. Antes de la menopausia: 5 - $25 \mathrm{UI} / \mathrm{L}$

2. El nivel alcanza incluso un punto más alto alrededor de la mitad del ciclo menstrual

3. El nivel llega a ser luego > en mujeres después de la menopausia: 14.2 - $52.3 \mathrm{UI} / \mathrm{L}$

4. Los niveles de HL son normalmente bajos durante la infancia.

Para los hombres mayores de 18 años de edad está alrededor de 1.8 - $8.6 \mathrm{UI} / \mathrm{L}$.

\section{Significado de los resultados anormales}

En las mujeres, un nivel de HL por encima de lo normal se observa:

I. Cuando las mujeres en edad reproductiva no están ovulando

2. Cuando hay un desequilibrio de las hormonas sexuales femeninas (como sucede con el síndrome de poliquistosis ovárica)

3. Durante o después de la menopausia

4. Síndrome de Turner

5. Cuando los ovarios producen pocas o ninguna hormona (hipofunción ovárica)

6. En los hombres, un nivel de HL por encima de lo normal puede deberse a:

7. Ausencia de testículos o testículos que no funcionan (anorquia)

8. Problema con los genes, como con el síndrome de Klinefelter 


\section{Sistema Genito - Urinario y Endocrino}

9. Glándulas endocrinas que son hiperactivas o forman un tumor (neoplasia endocrina múltiple).

En los niños, un nivel superior al normal se observa en la pubertad temprana (precoz).

Un nivel de HL más bajo de lo normal puede deberse a que la hipófisis no produce suficiente hormona (hipopituitarismo).

\section{Metabolismo de los hidratos de carbono}

\section{Examen de sangre de glucagón}

Mide la cantidad de una hormona llamada glucagón en la sangre. El glucagón es producido por células en el páncreas. Esta hormona ayuda a controlar su nivel de azúcar en la sangre al incrementarlo cuando es demasiado bajo.

\section{Razones por las que se realiza el examen}

El glucagón estimula al hígado a secretar glucosa. A medida que disminuye el nivel del azúcar en la sangre, el páncreas secreta más glucagón. Y conforme el azúcar en la sangre aumenta, el páncreas secreta menos glucagón.

El proveedor de atención puede medir los niveles de glucagón si una persona tiene síntomas de:

I. Diabetes

2. Glucagonoma (un raro tumor del páncreas) con síntomas de una erupción cutánea llamada eritema migratorio necrosante, pérdida de peso, diabetes leve, anemia, estomatitis, glositis

3. Deficiencia de hormona del crecimiento en los niños

4. Cirrosis del hígado (cicatrización del hígado y función hepática deficiente)

5. Glucemia baja (hipoglucemia)

6. Neoplasia endocrina múltiple tipo I (enfermedad en la que una o más de las glándulas endócrinas son hiperactivas o forman un tumor)

7. Pancreatitis (inflamación del páncreas).

\section{Resultados normales}

El rango normal es de 50 a 100 pg/mL. 


\section{Sistema Genito - Urinario y Endocrino}

\section{Significado de los resultados anormales}

Los resultados anormales pueden indicar que la persona puede tener una afección descrita arriba en la sección "Razones por las que se realiza el examen".

Algunos expertos ahora creen que los niveles altos de glucagón en la sangre contribuyen al desarrollo de diabetes en lugar de solo considerar un nivel bajo de insulina. Los medicamentos se han desarrollado para disminuir los niveles de glucagón o bloquear la señal del glucagón en el hígado.

Cuando su nivel de azúcar en la sangre es bajo, el nivel de glucagón en su sangre debería ser alto. Si no se ha incrementado, esto puede ayudar a identificar a las personas que tienen un riesgo mayor de presentar hipoglucemia severa que puede ser peligrosa.

El glucagón puede aumentar a causa de un ayuno prolongado.

\section{Examen del péptido $C$ de insulina}

El péptido-C es un producto que se crea cuando la hormona insulina se produce y libera en el cuerpo. El examen del péptido $C$ de insulina mide la cantidad de este producto en sangre.

\section{Razones por las que se realiza el examen}

El péptido $C$ se mide para establecer la diferencia entre la insulina producida por el cuerpo y la insulina inyectada en el organismo.

Alguien con diabetes tipo I o tipo 2 puede medirse su nivel de péptido $C$ para ver si su cuerpo está produciendo algo de insulina. También puede medirse en caso de baja azúcar en la sangre para ver si el cuerpo de la persona está produciendo demasiada insulina.

\section{Resultados normales}

Un resultado normal es de 0.5 a $2.0 \mathrm{ng} / \mathrm{mL}$.

Las personas con resistencia a la insulina, obesidad y diabetes tipo 2 pueden tener un alto nivel de péptido $C$ que es normal para ellos.

\section{Significado de los resultados anormales}

Un nivel de péptido $C$ se basa en el nivel de azúcar en la sangre. El péptido $C$ es una señal de que el cuerpo está produciendo insulina. Un bajo nivel (o la ausencia de péptido $C$ de 


\section{Sistema Genito - Urinario y Endocrino}

insulina) indica que el páncreas no está produciendo o está produciendo poca insulina.

I. Un nivel bajo puede ser normal si usted no ha comido recientemente. Sus niveles de azúcar e insulina en sangre serían entonces naturalmente bajos

2. Un nivel bajo es anormal si el azúcar en sangre es alto y su cuerpo debería estar produciendo insulina en ese momento.

\section{BIBLIOGRAFÍA SUGERIDA}

I. Burbridge S, Stewart I, Placzek M. Development of the Neuroendocrine Hypothalamus. Compr Physiol. 2016;6(2):623-643. Published 2016 Mar I5. doi:10.1002/cphy.cl50023

2.

Soto-Tinoco E, Guerrero-Vargas NN, Buijs RM. Interaction between the hypothalamus and the immune system. Exp Physiol. 20 I6; I0 I(I2): I463-I47I. doi:I0. I I I3/EP085560

3. Joshi MN, Whitelaw BC, Carroll PV. MECHANISMS IN ENDOCRINOLOGY: Hypophysitis: diagnosis and treatment. Eur J Endocrinol. 2018; I79(3):RI5I-RI63. doi:I0.I530/EJE-I7-0009

4.

Siebert DM, Rao AL. The Use and Abuse of Human Growth Hormone in Sports. Sports Health. 2018;10(5):419-426. doi:I0.II77//94|738| |8782688

5. Calzada-León R. Uso de hormona de crecimiento humana recombinante (HChr) 「Use of recombinant Human Growth Hormone (rHGH)]. Rev Med Inst Mex Seguro Soc. 20 I7;55(2): I 96-2 I 3.

6.

Cabrera-Reyes EA, Limón-Morales O, Rivero-Segura NA, Camacho-Arroyo I, Cerbón M. Prolactin function and putative expression in the brain. Endocrine. 20 I7;57(2): I99-2 I3. doi:I0.1007/s | 2020-0 I7-I346-x

\section{REFERENCIAS CONSULTADAS}

I. Amado Señarís, J.A. (2008). Trastornos de las Paratiroides. Universidad de Cantabria.Recuperado a partir de http://banzaideim.urv.cat/MedicalTest/Guides/MEDICINE\%201057.pdf 


\section{Sistema Genito - Urinario y Endocrino}

2. Bonilla, E. (1927). Correlación funcional entre el sistema nervioso de la vida vegetativa y las glándulas endocrinas.Editorial: Ciudad lineal, primera edición. Madrid.

3. Diarium.usal.es. (2017). Trastornos de las glándulas suprarrenales. Recuperado a partir de http://diarium.usal.es/lcal/files/2017//0/Trastornos-de-lasgl\%C3\%A Indulas-suprarrenales I.pdf

4. Diarium.usal.es. (2017). Trastornos de las glándulas suprarrenales. Recuperado a partir de http://diarium.usal.es/lcal/files/2017/I0/Trastornos-de-lasgl\%C3\%A Indulas-suprarrenales I.pdf

5. Diarium.usal.es. (2017). Trastornos de las glándulas suprarrenales. Recuperado a partir de http://diarium.usal.es/lcal/files/2017/10/Trastornos-de-lasgl\%C3\%AIndulas-suprarrenales I.pdf

6. Duque Ramírez, L. \& Rubio Vanegas, H. (2006). Endocrinología médica integral. Editorial: Quimbaya, primera edición. Colombia

7. Diarium.usal.es. (2017). Trastornos de las glándulas suprarrenales. Recuperado a partir de http://diarium.usal.es/lcal/files/2017//0/Trastornos-de-lasgl\%C3\%AIndulas-suprarrenales I.pdf

8. Duque Ramírez, L. \& Rubio Vanegas, H. (2006). Endocrinología médica integral. Editorial: Quimbaya, primera edición. Colombia

9. Gerard J. Tortora. Bryan Derrickson (2006) Principios de Anatomía y Fisiología. Editorial Médica Panamericana. I3ra Edición. Capítulo 18. Pág. 720 - 72I.

10. Hidalgo, C. R. (20II). Sendocrino-biologia.blogspot.com. Recuperado a partir de biologia.blogspot.com/20I I/08/glandula-pineal.html

II. Jiménez, P. A. (2015). Sistema Endocrino Función y Definición. Recuperado a partir de https://www.educandose.com/el-sistema-endocrino/

12. Marta C. Romano, C. P. (2016). accessmedicina.mhmedical.com. Recuperado a partir de accessmedicina.mhmedical.com: https://accessmedicina.mhmedical.com/book.aspx?bookid= 1858

13. Neonatales, E. (2016). Anatomía y fisiología del sistema endocrino. Recuperado a partir de http://ajibarra.org/anatomia-y-fisiologia-del-sistema-endocrin

14. Redacción Fisaude. (2009). Glándulas Tiroides. Hipotiroidismo. Recuperado a partir de http://blog.fisaude.com/nutricion/nutricion-profesional/glandulastiroides/Hipotiroidismo.html

15. Redacción Fisaude. (2009). Glándulas Tiroides. Bocio. Recuperado a partir de Recuperado a partir de http://blog.fisaude.com/nutricion/nutricionprofesional/glandulas-tiroides/bocio.html

16. ROCA, D. A. (20l8). encolombia.com. Recuperado a partir de https://encolombia.com/libreria-digital/Imedicina/fisio-endocrina/fisiologiaendocrinatimol 


\section{Sistema Genito - Urinario y Endocrino}

17. Stephan, S. (2004). Lo Esencial En Sistema Endocrino y Aparato Reproductor. Editorial: Elsevier, segunda edición. España.

18. Stephan, S. (2004). Lo Esencial En Sistema Endocrino y Aparato Reproductor. Editorial: Elsevier, segunda edición. España.

19. Stephen J. McPHEE. Gary D. HAMMER. (n.d.) Fisiopatología de la enfermedad. Una introducción a la medicina clínica. Editorial: McGraw Hill. LANGE. 6ta Edición. Capítulo 20. Pág. $554-564$.

20. Ulrich Welsch \& Johannes Sobotta. (2006). Histología.Editorial: Panamericana, segunda edición. España. 


\section{Sistema Genito - Urinario y Endocrino}

\section{AGRADECIMIENTO}

A MIS PADRES POR SER GUÍAS EN MI CAMINAR COMO PERSONA Y POR ACOMPAÑARME EN TODO LOS MOMENTOS DE LA VIDA

A MI AMADA ESPOSA, COMPAÑERA DE CAMINO Y AMIGA FIEL

A MIS HIJOS POR SER MI MAYOR MOTIVACIÓN PARA FORMARME CADA DÍA

A MARÍA ELENA MOYA MARTÍNEZ POR SU EJEMPLO Y DEDICADIÓN PROFESIONAL

A MIS HERMANOS POR SER COLUMNA DE SOLIDARIDAD Y CARIÑO

\section{Dr. Patricio Vallejo}



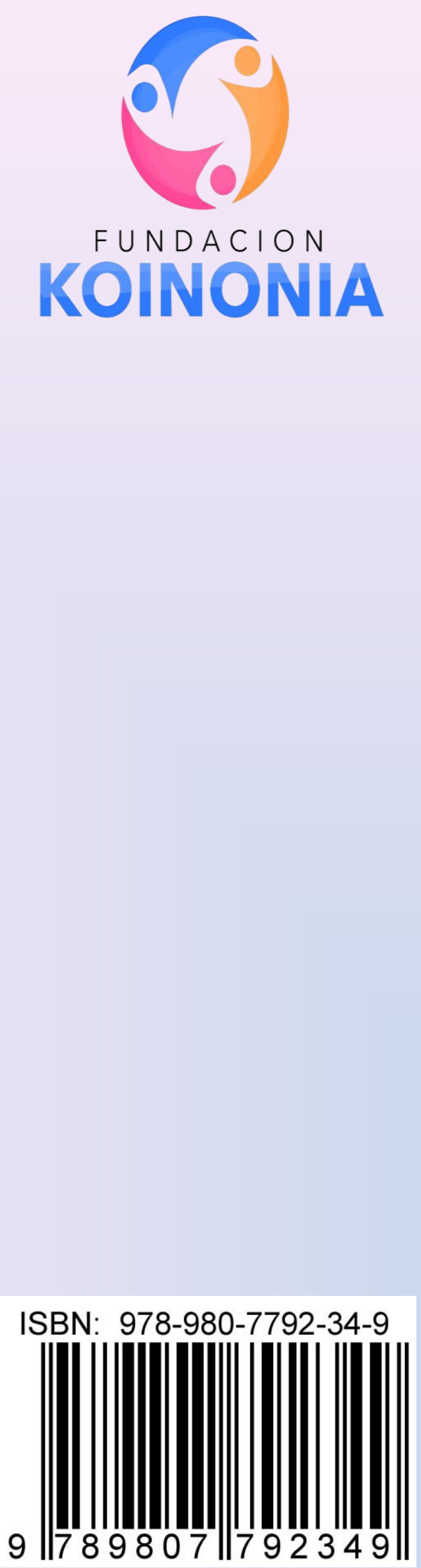